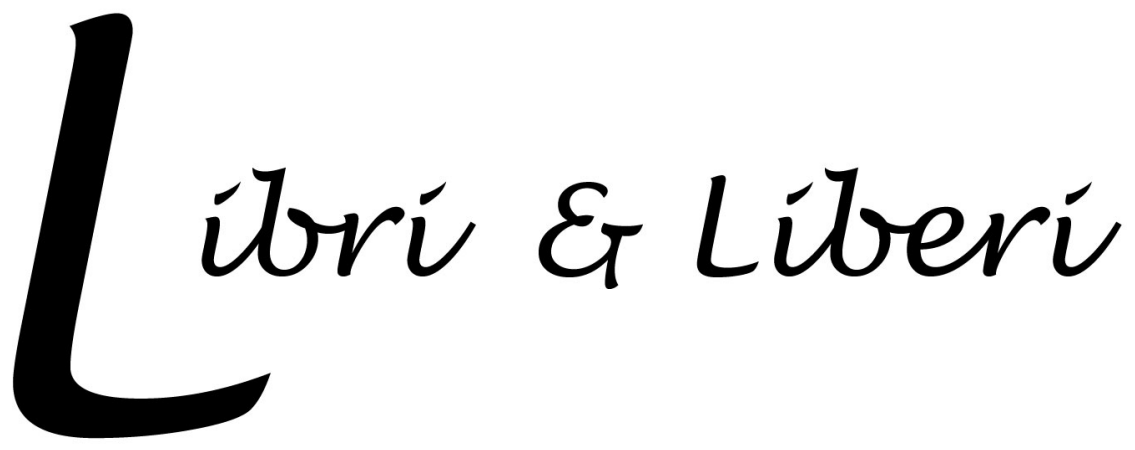

Časopis za istraživanje dječje književnosti i kulture

Journal of Research on Children's Literature and Culture

God. 2 br. 2 • 2013 • Vol. 2 No. 2

\author{
Glavna urednica / Editor-in-Chief \\ Smiljana Narančić Kovač (Zagreb) \\ Zamjenici glavne urednice / Deputy Editors \\ Maja Verdonik (Rijeka), Tihomir Engler (Varaždin) \\ Tajnica uredništva / Journal Administrator \\ Ivana Milković (Zagreb) \\ Uredništvo / Editorial Board
}

Sandra L. Beckett (St. Catharines), Milena Mileva Blažić (Ljubljana), Clare Bradford (Melbourne), Penni Cotton (Roehampton), Bernd Dolle-Weinkauff (Frankfurt), Giorgia Grilli (Bologna), Marijana Hameršak (Zagreb), Peter Hunt (Cardiff), Veljko Krulčić (Zagreb), Bettina Kümmerling-Meibauer (Tübingen), Berislav Majhut (Zagreb), Janelle B. Mathis (Denton, TX), J. Cynthia McDermott (Los Angeles), Ivana Milković, mlada urednica / Junior Editor (Zagreb), Thomas Möbius (Gießen), Maria Nikolajeva (Cambridge), Marek Oziewicz (Minneapolis, MN), Dubravka Težak (Zagreb), Ingrid Tomkowiak (Zürich), Ester Vidović (Rijeka), Diana Zalar (Zagreb), Dubravka Zima (Zagreb), Terrell A. Young (Provo, UT), Jack Zipes (Minneapolis, MN)

Hrvatska udruga istraživača dječje književnosti • Zagreb Croatian Association of Researchers in Children's Literature • Zagreb 
Libri \& Liberi: časopis za istraživanje dječje književnosti i kulture

Godište 2 - Broj 2 - 2013.

Libri \& Liberi: Journal of Research on Children's Literature and Culture

Volume 2 - Number 2 - 2013

UDK 82-93

UDK $371.3: 82$

UDK 82.0-93

ISSN 1848-3488

(C) 2013 Hrvatska udruga istraživača dječje književnosti (HIDK) / Croatian Association of Researchers in Children's Literature (CARCL), Zagreb, Croatia

Libri \& Liberi znanstveni je i stručni časopis koji izlazi dva puta godišnje u tiskanom i elektroničkom izdanju (www.librietliberi.org) i objavljuje znanstvene i stručne članke o svim temama koje se tiču dječje književnosti, književnosti za mladež, njihova široko shvaćenoga kulturnoga konteksta i međukulturnih kontakata u području književnosti i medija, te njeguje interdisciplinarnost i intermedijalnost. Za objavljivanje u časopisu Libri \& Liberi razmatraju se neobjavljeni radovi na hrvatskom, engleskom ili njemačkom jeziku, a iznimno i na drugim jezicima, uz prijevod na hrvatski. Radovi se dostavljaju na adresu librietliberi@ gmail.com. Upute za pripremu rukopisa i detaljan opis časopisa nalaze se na mrežnoj stranici <www. librietliberi.org>.

Libri \& Liberi is an academic journal published twice a year in printed and electronic form (www.librietliberi. org). It publishes peer-reviewed academic papers on various topics in the field of children's literature and young adult literature and on related topics, on their wider cultural contexts, and on their intercultural contacts in the fields of literature and the media. The journal particularly appreciates interdisciplinary approaches and intermediality. Original manuscripts in English, German and Croatian are considered for publication. Manuscripts and inquiries should be submitted electronically to librietliberi@ gmail.com. Guidelines for contributors and more details about Libri \& Liberi can be found at $<$ www.librietliberi.org $>$.

Prilozi objavljeni u časopisu referiraju se u / Papers published in Libri \& Liberi are referenced in: MLA International Bibliography and MLA Directory of Periodicals; ULRICHSWEB - Global Serials Directory; CEEOL (Central and Eastern European Online Library); Hrčak (Portal znanstvenih časopisa Republike Hrvatske / Croatian Portal of Academic Journals).

Prilozi objavljeni u časopisu dostupni su i putem EBSCOhost akademskih baza podataka.

Articles from Libri \& Liberi are also accessible through EBSCOhost research databases.

Adresa uredništva / Address: Libri \& Liberi, Savska cesta 77, HR-10000 Zagreb

E-mail: librietliberi@gmail.com; editor@librietliberi.org

Phone: +38516327323/+38516327319

Tajnice / Journal office assistants: Maja Loborec, Tea Terzić

Design: Antonija Balić Šimrak

UDK izradila / UDC classification: Andreja Tominac

Lektura / Language editing: Mark Davies (engleski / English), Nadia Preindl (njemački / German)

Korektura / Proofreading: Nika Vučić

Računalni slog i prijelom / Layout: Nataša Vuković

Izdavač / Publisher: Hrvatska udruga istraživača dječje književnosti, Savska cesta 77, HR-10000 Zagreb

Tisak / Printed by: Tiskara Zelina d.d.

Naklada / Print run: 500

Cijena primjerka / Price per copy: $50 \mathrm{kn} / 10$ EUR

Godišnja pretplata za pojedince: $100 \mathrm{kn}$; Godišnja pretplata za ustanove: $200 \mathrm{kn}$

Individual subscription: 20 EUR; Institutional subscription: 50 EUR

Pitanja o pretplati upućuju se na adresu / Subscription inquiries should be sent to subscr@librietliberi.org

Pretplate i donacije primaju se uplatama na žiro račun br. 2360000-1102154030; IBAN: HR602360000 1102154030 (Hrvatska udruga istraživača dječje književnosti - za Libri \& Liberi)

Subscriptions and donations are welcome to the account No. 2360000-1102154030; Swift Code: ZABAHR2X; IBAN: HR6023600001102154030 (to HIDK - for Libri \& Liberi). 


\section{1月ค \\ HLAPIĆ 2013.}

\section{SADRŽAJ • CONTENTS}

\section{Uvodnik • Editorial}

\section{STUDIJE • PAPERS}

\section{Hans-Heino Ewers}

179 Children's Literature in Europe at the Start of the $20^{\text {th }}$ Century and the Intellectual Place of Ivana Brlić-Mažuranić's Children's Story Čudnovate zgode šegrta Hlapića

Dječja književnost u Europi početkom dvadesetoga stoljeća i intelektualno mjesto dječje priče Čudnovate zgode šegrta Hlapića Ivane Brlić-Mažuranić

Željka Flegar

Ogled / essay

187 The Great Literary Improvisers

Veliki književni improvizatori

\section{Martin Machata}

Izvorni znanstveni rad / original research paper

209 O prijevodu i prevođenju Čudnovatih zgoda šegrta Hlapića na slovački The Translation and Translating of Čudnovate zgode šegrta Hlapića into Slovak

\section{Vladimira Rezo}

Izvorni znanstveni rad / original research paper

225 Prostor u Čudnovatim zgodama šegrta Hlapića

Notions of Space in The Brave Adventures of Hlapich the Apprentice

Jelena Vignjević

Izvorni znanstveni rad / original research paper

241 Jezičnostilske osobitosti rukopisa i prvotiska Čudnovatih zgoda šegrta

Hlapića u jezičnopovijesnom kontekstu

Specific Linguistic and Stylistic Features of the Manuscript and the First Printing of

$\breve{C}$ udnovate zgode šegrta Hlapića in the Context of the Linguistic History of Croatian

Spomenka Štimec

Izvorni znanstveni rad / original research paper

253 Azijsko putovanje Šegrta Hlapića na krilima esperanta

The Asian Journey of Hlapich the Apprentice on the Wings of Esperanto

Stručni rad / report paper

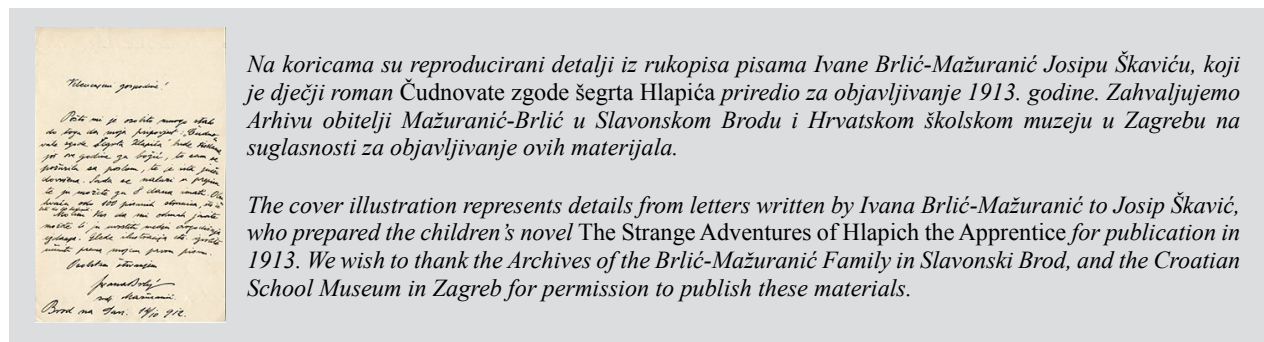




\section{GRAĐA • FACT FILE}

269 Letters about Hlapich / Pisma o Hlapiću (Berislav Majhut, Sanja Lovrić Kralj)

\section{PRIKAZI • REVIEWS}

359 Enchanting and Erudite. Marina Warner. 2012. Stranger Magic: Charmed States \& the Arabian Nights (Nada Kujundžić)

361 Playing as a Serious Task. Cherie Allan. 2012. Playing with Picturebooks: Postmodernism and the Postmodernesque (Mateja Latin, Dina Alexandra Pavković)

364 Robinson as Children's Reading. Andrew O'Malley. 2012. Children's Literature, Popular Culture, and Robinson Crusoe (Berislav Majhut)

368 Brand New Harry Potter Critical Essays. 2012. Cynthia J. Hallett \& Peggy J. Huey, eds. J.K. Rowling: Harry Potter (Maja Njire)

373 Odgojno-obrazovni potencijal slikovnice. Marnie Campagnaro. 2012. Narrare per immagini: uno strumento per l'indagine critica (Corinna Jerkin)

374 Dijete i zoo-svijet - ikonografska neotenija. Ana Batinić. 2012. U carstvu životinja: animalističko čitanje hrvatskih dječjih časopisa (Suzana Marjanić)

377 Dvije knjige o regionalnoj književnosti. Vanesa Begić. 2012. Suvremena književnost za djecu u Istri i Valentina Majdenić. 2013. Regionalni tekst dječje književnosti (Martina Jurišić)

380 Obljetnica kao poticaj. Marina Protrka Štimec, Dijana Zalar i Dubravka Zima, ur. 2013. Veliki vidar - stoljeće Grigora Viteza (Katarina Ivon)

383 Znanstvena brižnost i marno sročene misli. Vinko Brešić, ur. 2013. Članci. Sabrana djela Ivane Brlić-Mažuranić. Kritičko izdanje (Dubravka Zima)

388 Kako iskazati neiskazivo. Kornelija Kuvač-Levačić. 2013. Moć i nemoć fantastike (Petra Mrduljaš Doležal)

\section{KRONIKA ・ EVENTS}

393 ChLA 2013 Conference Play and Risk in Children's and Young Adult Literature, Biloxi, Mississippi (USA), 13-16 June 2013 (Martina Jurić)

395 Tomislav Torjanac u Galeriji Klovićevi dvori, Zagreb, 19. 11. 2013. - 12. 1. 2014. (Vedran Markulin)

397 Ivan Kušan u Galeriji Učiteljskoga fakulteta, Zagreb, 28. 11. 2013. - 10. 1. 2014. (Danijel Žabčić)

399 Manifestacija Hlapić 2013. Hrvatska, 2013. (Ivana Faletar Horvatić)

406 Bilješke o autorima • Notes on Contributors

409 Recenzenti u ovom godištu • Reviewers in this Volume 


\section{Uvodnik • Editorial}

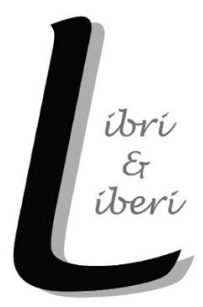

Drage čitateljice i čitatelji,

broj koji držite u rukama posvećen je stotoj obljetnici objavljivanja Čudnovatih zgoda šegrta Hlapića Ivane Brlić-Mažuranić, najvažnijega dječjega romana hrvatske književnosti. Logotip Manifestacije Hlapić 2013. na stranicama časopisa naznačuje da se i Libri \& Liberi pridružuje svima koje je Hrvatska udruga istraživača dječje književnosti tijekom 2013. godine okupila oko Šegrta Hlapića. Održano je više od dvije stotine aktivnosti, od međunarodne znanstvene konferencije do velikoga broja radionica, izložba i priredbi, sve u čast ovoga hrvatskoga, ali i međunarodnoga dječjega klasika. O Manifestaciji detaljnije piše Ivana Faletar Horvatić u rubrici Kronika.

Rubrika Studije cijela je posvećena Šegrtu Hlapiću. Hans-Heino Ewers u nadahnutom je ogledu prikazao intelektualno mjesto ovoga romana u kontekstu europske dječje književnosti početkom dvadesetoga stoljeća. Tu je temu autor izložio i prigodom središnje proslave stote obljetnice i otvaranja Međunarodne znanstvene konferencije Od čudnovatog do čudesnog, u travnju 2013. godine, i tako osigurao prikladan uvod za znanstvene rasprave koje su uslijedile. Na jednako primjeren način, otvarajući romanu o Hlapiću ne samo povijesni nego i suvremeni međunarodni intelektualni obzor, ogled u ovome broju časopisa uvodi u niz studija koje Hlapiću pristupaju na različite načine, otkrivajući pritom njegova mnoga lica i naznačujući smjerove budućih istraživanja. Tako studija Željke Flegar ,The Great Literary Improvisers“ analizira Hlapića sa stajališta improvizacijskoga kazališta te ga povezuje s drugim remek-djelima Zlatnoga doba dječje književnosti. Autorica pokazuje da sva ta djela, uključujući i Hlapića, dio svoje postojanosti, univerzalnosti i prilagodljivosti duguju upravo kreativnim improvizacijskim procesima koji se u njima manifestiraju. Martin Machata piše „O prijevodu i prevođenju Čudnovatih zgoda šegrta Hlapića na slovački”. Osim što detaljno analizira slovački prijevod iz 1940. godine kao međukulturni prostor susreta dvaju naoko udaljenih kultura i jezika, autor argumentirano pojašnjava kontekst i razloge njegova pojavljivanja upravo za vrijeme Drugoga svjetskoga rata. Ujedno postavlja i pitanje aktualnosti ovoga sedamdesetak godina staroga prijevoda i potrebe njegova osuvremenjivanja kako bi se obnovilo zanimanje za Hlapića među slovačkim čitateljima. Sljedeće su dvije studije usmjerene na analizu samoga romana, prva na tematske, a druga na stilsko-jezične aspekte. Vladimira Rezo određuje Šegrta Hlapića dvojako: kao 
roman ceste i roman prostora te analizira mjesta i prostore zastupljene u romanu u potrazi za istaknutim spacijalnim hvatištima oko kojih se uspostavlja narativni prostor romana. U prvi plan dolaze kategorije kuće i ceste, kao i specifična mjesta kao što su prag ili raskrižje, sajam i cirkus. Univerzalnosti romana pridonosi ispreplitanje statične i dinamične perspektive, a značenjski se postav romana u cjelini, zaključuje autorica, otvara pluralizmu različitih interpretacija. Jelena Vignjević analizira i uspoređuje jezična i stilska obilježja rukopisa i prvotiska romana, te utvrđuje promjene u prvotisku, koje su narušile prvobitne autoričine namjere i promijenile pojedine stilske i značenjske sastavnice izvornoga teksta. Razloge za takvu situaciju nalazi autorica u jezičnopolitičkim okolnostima u hrvatskom povijesnom kontekstu početkom dvadesetoga stoljeća. Rubriku Studije zaokružuje rad Spomenke Štimec „Azijsko putovanje Šegrta Hlapića na krilima esperanta“ u kojemu se detaljno opisuju okolnosti i situacije koje su prijevod Šegrta Hlapića na esperanto, iz 1998. godine, pretvorile u posredni prijevod za izdanja ovoga romana na mnogim azijskim jezicima. Zahvaljujući esperantu, danas se Hlapić čita na japanskom, kineskom, perzijskom, bengalskom, vijetnamskom i korejskom jeziku, postao je poznat i prihvaćen u kulturama u kojima se ti jezici govore, te zahvaljujući tome raste zanimanje za Hlapića u međunarodnoj javnosti.

I rubrika Građa posvećena je Šegrtu Hlapiću. Berislav Majhut i Sanja Lovrić Kralj brižljivo su priredili za objavljivanje prijepise pisama iz korespondencije Ivane Brlić-Mažuranić u kojima se spominje Hlapić, kao i druge materijale, fotografije i bilješke vezane uz roman i njegovu scensku adaptaciju 1934. godine. Ovi prilozi na specifičan i jedinstven način osvjetljavaju svakodnevnicu velike spisateljice u kojoj je roman nastao, kao i njezina nastojanja i želje da djelo bude primjereno predstavljeno te da trajno zaživi kao dječje štivo. Otkrivamo autoričinu nježnu povezanost sa svojim romanom, kao i brigu cijele obitelji i bliskih rođaka za njegovu sudbinu, i to usprkos njihovim državničkim ili dnevnim preokupacijama, ali i razumijevanje i podršku mnogih uglednika i kulturnih djelatnika, onih suvremenika koji su dobro razumjeli njegovu važnost. Ne možemo znati je li spisateljica pod kraj života i nadalje vjerovala u Hlapićev blistav put, no sigurno bi bila zadovoljna što i nakon stotinu godina ovo kratko i uzbudljivo, mudro djelo jednakom snagom privlači nove čitatelje, a književne znanstvenike potiče na neprestana nova tumačenja razloga njegove, možda ipak nikada do kraja razjašnjive vitalnosti i trajne vrijednosti.

Radovi i prilozi u ovome broju Libri \& Liberi pridonose toj stalnoj i nedovršenoj potrazi za razumijevanjem Hlapićeve tajne, a time i potrazi za razumijevanjem biti vrhunske umjetničke dječje književnosti. 


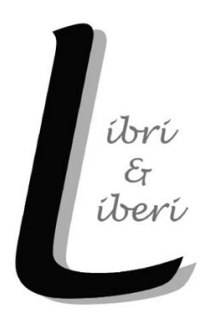

\section{Dear Readers,}

The issue in your hands is dedicated to the centennial of the publication of $\check{C}$ udnovate zgode šegrta Hlapića [The Strange Adventures of Hlapich the Apprentice], the most important children's novel of Croatian children's literature. The logo of the celebrations titled Hlapic 2013 on the pages of this issue indicates that Libri \& Liberi joins all those who have been involved in celebrating the $100^{\text {th }}$ anniversary of Hlapich the Apprentice led

by the Croatian Association of Researchers in Children's Literature during 2013. Over two hundred activities took place, from an international research conference to many workshops, exhibitions and performances, all in honour of this Croatian and international children's classic. The celebrations are described in more detail by Ivana Faletar Horvatic in the Events section.

The Studies section wholly focuses on Hlapich the Apprentice. Hans-Heino Ewers explains the intellectual position of this novel in the context of European children's literature at the beginning of the $20^{\text {th }}$ century. This inspiring essay was also presented on the occasion of the central celebration of the $100^{\text {th }}$ anniversary of the novel and the opening of the International Research Conference From the Strange to the Wondrous in April 2013, introducing most suitably the discussions that followed. In an equally appropriate way, by mapping both the historical and the present day intellectual territory of the novel and its international context, the essay introduces other papers which approach Hlapich from different perspectives. Their authors reveal its many facets and mark directions for future research. Thus, Željka Flegar in her paper "The Great Literary Improvisers" analyses Hlapich from the point of view of the improvisational theatre, and considers it together with other masterpieces of the Golden Age of children's literature. The author shows that these works, including Hlapich, owe much of their constancy, universality and adaptability precisely to the creative improvisatory processes that are manifested in them. Martin Machata focuses on "The Translation and Translating of Čudnovate zgode šegrta Hlapića into Slovak". In addition to a detailed analysis of the 1940 Slovak translation as an intercultural meeting space of two seemingly distant cultures and languages, the author provides a well-argued explanation of the context and reasons for its appearance during the Second World War. He also raises the question of the obsolescence of this more than seventy-year-old translation and of the need for it to be revised so that it can again attract interest for Hlapich among Slovak readers. The next two studies focus on analyses of the novel itself, the first on the thematic aspects, and the second on the issues of language and style. Vladimira Rezo defines Hlapich the Apprentice as a road novel and as a space-oriented novel and analyses the notions of place and space as presented in the narrative, in search of spatial points of reference which establish the foundations of the narrative space. Categories such 
as house and road, as well as specific places like threshold or crossroads, fair and circus, come to the fore. The author concludes that the interlacing of the static and dynamic perspectives contributes to the universality of the novel, and also that the novel as a whole opens up towards a plurality of interpretations. Jelena Vignjević analyses the linguistic and stylistic traits of the manuscript in comparison with the first printing of the novel, and finds numerous changes in the published version, which spoiled the writer's initial intentions and altered specific stylistic and semantic elements of the original text. The author of the study explains the reasons for the modifications found in the first printing of Hlapich the Apprentice in the historical linguistic-political context in Croatia at the beginning of the $20^{\text {th }}$ century. The Studies section concludes with "The Asian Journey of Hlapich the Apprentice on the Wings of Esperanto", a paper by Spomenka Štimec describing the circumstances which turned the 1998 translation of Hlapich the Apprentice in Esperanto into a relay translation, rendering new editions of the novel in several Asian languages. As a result, Hlapich is today read in Japanese, Chinese, Persian, Bengali, Vietnamese and Korean. The novel has become well known and accepted in cultures in which these languages are spoken, and there has consequently been growing interest for Hlapich in the international community.

The Fact File section also brings materials related to Hlapich the Apprentice. Berislav Majhut and Sanja Lovrić Kralj have carefully edited and prepared for publication the letters from Ivana Brlić-Mažuranić's correspondence, photographs, notes and other materials related to the novel and to its theatrical adaptation first performed in 1934. These items and letters in a special and rather unique way shed light on the everyday life of the great writer, on her endeavours to appropriately present her work, and on her wishes for the novel to remain permanently engaging and admired reading for children. They also reveal the author's tender bond with her novel, the care of the whole family and close relatives for its fate, despite their engagement in state affairs or their everyday ordeals. They document appreciation for the novel and the support of many distinguished persons and notable cultural workers, contemporaries who well understood its importance. We cannot know if the author, towards the end of her life, still believed in the dazzling path Hlapich was to take, but she would certainly have been pleased that a hundred years after its creation, this short and exciting, wise piece has the same power to attract new readers, and that it continues to inspire literary scholars to strive to explain the reasons for its (perhaps never fully explicable) vitality and enduring value.

The studies and other materials in this issue of Libri \& Liberi contribute to this permanent and unfinished search for an understanding of the secret of Hlapich, which is, in its own way and at the same time, a search for an understanding of the essence of children's literature at its best. 


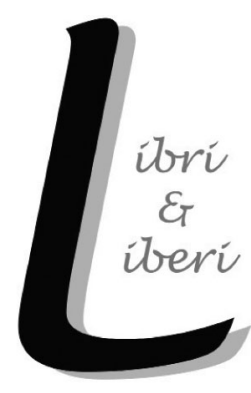

\section{Studije \\ Papers}





\section{Hans-Heino Ewers}

Goethe University, Frankfurt - Institute for Children's Literature Research ewers@em.uni-frankfurt.de

\section{Children's Literature in Europe at the Start of the $20^{\text {th }}$ Century and the Intellectual Place of Ivana Brlić-Mažuranić's Children's Story Čudnovate zgode šegrta Hlapića}

Ogled / essay

Primljeno / received 30. 4. 2013.

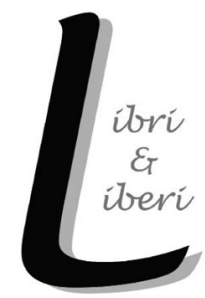

The essay presents the cultural circumstances and the main ideas of the educational reform in Europe at the beginning of the $20^{\text {th }}$ century and gives an overview of the trends found in children's literature of the time. The author places C̆udnovate zgode šegrta Hlapića [The Strange Adventures of Hlapich the Apprentice], a Croatian classic by Ivana Brlić-Mažuranić, in the tradition of children's non-fantastic literature of childhood autonomy, of a partly idyllic, partly parabolic, nature. He also relates it to stories by the German children's author Otfried Preußler, which appeared in the mid $20^{\text {th }}$ century, at the time when Hlapich was translated into German. It is the kind of literature which aims to create for its young readers the feeling of happy agreement between the self and the world, and it thus instils a basic sense of trust in its child readers.

Keywords: children's literature, Europe, turn of the $20^{\text {th }}$ century, Ivana Brlić-Mažuranić, The Strange Adventures of Hlapich the Apprentice

The late $19^{\text {th }}$ century, and especially the turn of the century, was marked by artistic, literary, and pedagogic reform movements in almost all European countries. Ideas about reform surfaced in the field of children's literature as well, though, admittedly, without influencing the greater majority of publications. The common thread of these reform movements was a rediscovery of childhood, given voice

This essay was presented as an invited talk at the jubilee celebration Hlapić 2013 at the Croatian Academy of Sciences and Arts in Zagreb, Croatia, on 17 April 2013. This celebration was also the opening ceremony of and the introduction to the International Research Conference From the Strange to the Wondrous: 100 Years of the Strange Adventures of Hlapic the Apprentice, which took place in Slavonski Brod, Croatia from 18 to 20 April 2013. 
by Ellen Key of Sweden in the proclamation of the Century of the Child. ${ }^{2}$ The theorists of this era referred to many of the theories of childhood from the late $18^{\text {th }}$ and early $19^{\text {th }}$ centuries: what Jean-Jacques Rousseau had suggested in the $18^{\text {th }}$ century, namely that childhood was in its essence entirely misunderstood, was now applied to the bourgeois $19^{\text {th }}$ century - the Belle Époque. The diverse currents of pedagogical reform in the late $19^{\text {th }}$ and early $20^{\text {th }}$ centuries largely consist of a revival of Rousseau's Enlightenment philosophy of childhood: children are fundamentally different from adults and must be respected in this difference. Children see, think, and feel differently from adults. They have their own worldview and their own needs and interests. It was thought that whoever was continuously involved with children ought to accustom themselves unconditionally to children's ways.

\section{Neoromanticism, Fairy Tales and Fantasy Stories for Children}

Other currents of reform focused on the Romantic concept of the child from the period around 1800. Following this theory, children were differentiated from adults in that they still had access to a mythic-animistic world view. For children, all natural phenomena were animate and the world was ruled by good and evil spirits. Around 1900, there was renewed interest in taking seriously the idea that children think primitively. People once again began to consider in earnest the child's capacity for enthusiasm for everything wonderful and magical. Around this time, many people returned to the Romantic notion, from around 1800, that traditional, so-called 'folk poetry' best expressed the child's manner of thinking. Admittedly, 'folk poetry' had to be fundamentally reworked in order to be understandable to children. In Germany, for example, Wilhelm Matthießen produced children's versions of traditional fairy tale lore, the first edition of which appeared in 1923 under the title Das alte Haus. Ein Märchenbuch für Kinder zum Vorlesen [The Old House: A Fairy Tale Book for Reading Aloud to Children].

Not only did German Romanticism establish so-called 'folk poetry' as children's reading material in the early $19^{\text {th }}$ century, but it also went on to create children's stories in the fantastic mode, exemplarily embodied in the work of E.T.A. Hoffmann. This side of the Romantic programme for children's literature also saw a revival around 1900. England in particular experienced a new blossoming of children's fantasy literature; here it is worth mentioning Lewis Carroll, Edith Nesbit, James Matthew Barrie, Kenneth Graham, and Pamela Travers. Interestingly, Travers's Mary Poppins stories are closely related to E.T.A. Hoffmann's literature of the fantastic. This great variety of children's fantasy literature classics, still

\footnotetext{
${ }^{2}$ Her book on education Barnets århundrade from 1900 was translated in English in 1909 as The
} Century of the Child. 
popular today, put England at the forefront of the development of European children's literature. England continues to have a leading position, which has spread worldwide, not least because of J.K. Rowling's Harry Potter novels. Exceptional German children's fantasy stories from this time include Otto Julius Bierbaum's free adaptation of Pinocchio, Zäpfel Kerns Abenteuer [Adventures of Zäpfel Kern] from 1905, and Gerdt von Bassewitz's play Peterchens Mondfahrt [Peterkin's Trip to the Moon] from 1911.

\section{New Realism}

At the turn of the $20^{\text {th }}$ century, however, Germany was primarily taken up with a renewal of realistic children's literature, both in verse and in prose. Essentially, pedagogy reform looked back to the discourse of the concept of childhood of Rousseau and the Enlightenment rather than to the Romantic discourses on childhood. Accordingly, children, too, were led to perceive the world realistically. With these currents of reform, fresh literary demands were brought to bear on children's literature. Richard (1863-1920) and Paula Dehmel (1862-1918) renewed German children's poetry with their collection Fitzebutze (1900, illustrated by Ernst Kreidolf). Here, we find the impulsive, uncensored, lyrical self-expression of a child. In Paula Dehmel's Singinens Geschichten [Singine's Stories] from 1903, published as a book in 1921, we see modern first-person narration by a child: here, the child is the centre of perception and value judgement, and no adult interference occurs. These works by the Dehmels bring back the sort of consistently anti-authoritarian children's literature that had already appeared in the late 18th century. Mention should also be made of Christian Morgenstern, who wrote his children's verses around the turn of the century. These were then collected and published posthumously as Klein Irmchen [Little Irma] in 1921. His nonsense poems Galgenlieder [Gallows Songs], published in 1905, however, were not considered children's literature until the 1960s.

The turn of the century also saw a revival of the picturebook, especially under the influence of English illustrators such as Randolph Caldecott, Kate Greenaway, and Walter Crane. Art Nouveau artists like Ernst Kreidolf, Carl Hofer, Karl F.E. von Freyhold or the Austrians Heinrich Lefler and Joseph Urban were also influential. Furthermore, a two-dimensional drawing style was developed, somewhat reminiscent of children's drawings. All in all, the turn of the century was a period of varied and diverse renewals and one of the most important and productive periods for the development of western European children's literature, not only in England and Germany, as described here, but also in countries like France, Belgium, the Netherlands, and in Scandinavia. 


\section{Writing for Middle-Class and Working-Class Children}

The underlying rediscovery of childhood and the emphatic turn towards the child reader, however, took very different forms when directed at bourgeois or middle-class children rather than at children from the lower classes, especially working-class children. While the middle classes allowed their children their own sphere of existence, which fundamentally differentiated itself from the world of adults, lower-class children were much more heavily involved in the adult world, an involvement that left them very little free time.

Teachers who committed themselves to reform movements in education wrote sketches and stories about the world of the big city aimed at working-class children just beginning school. On one hand, these stories stayed close to the child's experiential perspective and thus to the principle of starting from the child. On the other hand, they focused attention on the city, the industrial world of work, and the social problems of industrial society. This trend, partly naturalistic and partly tinged with impressionism, started in Germany with Ilse Frappan's Hamburger Bilder für Kinder [Hamburg Pictures for Children] (1899), Fritz Gansberg's Streifzüge durch die Welt der Großstadtkinder [Exploring the World of the City Children] (1904) and Heinrich Scharrelmann's Ein kleiner Junge [A Little Boy] (1908), and culminated in Carl Dantz's penetrating portrait of the circumstances of a working-class boy, Peter Stoll (1925).

The theme of the modern metropolis first became mixed up with literature for children of the middle classes during the Weimar Republic. The tradition of big city novels for children often involved plots reminiscent of detective or crime novels; examples include Wolf Durian's Kai aus der Kiste [Kai from the Grate] (1927), Erich Kästner's Emil und die Detektive [Emil and the Detectives] (1928), Pünktchen und Anton [Dot and Anton] (1931), and Wilhelm Matthießen's (18911965) Das rote U [The Red U] (1932). Here, we are dealing with a children's literature that takes the child's manner of perception as its basis but looks, at the same time, at modern society and the world of adults. Thus, childhood autonomy was partially raised even in the milieu of the bourgeoisie. The social reality of the early $20^{\text {th }}$ century, however, did not allow even the middle classes to keep their children entirely apart from social conflicts. The First World War had already pushed every thought of an autonomous children's world far into the distance. In warring countries like Germany, France, England, and Italy, children became witnesses of a great and terrifying era. They were designated as little patriots who cared about nothing other than their homeland so that, if necessary, they would give their lives for their country. It is not surprising, then, that socially critical 
children's literature, meant to prepare young readers for an inharmonious world rife with contradiction, probably reached its peak in the $20^{\text {th }}$ century.

\section{A World of Simplicity - A Children's Literary Vision}

A children's literature of childhood autonomy, which gave children a world of their own, existed alongside more modern, socially critical children's literature in the early $20^{\text {th }}$ century. Romantic-fantastic variants of the former were particularly prominent in England, as mentioned above. Further, a non-fantastic variant of children's literature of childhood autonomy developed on the Continent, largely renouncing magical motifs and fantastic elements. This type of modern children's literature from the early $20^{\text {th }}$ century brings us to a classic of Croatian children's literature, the $100^{\text {th }}$ anniversary of which is celebrated this year. In my opinion, Ivana Brlić-Mazuranić's children's story Čudnovate zgode šegrta Hlapića [The Strange Adventures of Hlapich the Apprentice], from 1913, which I know only through the German translation by Else Byhan published in 1959 under the title Die verschwundenen Stiefel [The Missing Boots], belongs to this category of literature.

Ivana Brlić-Mažuranić's story presents a world of extreme simplicity, transparency, clarity, and unambiguousness that ideally corresponds to the capacity for understanding among kindergarten and elementary school children. This sort of literature temporarily allows its child audience to forget the sense of being permanently surrounded by a world unintelligible and impenetrable to them. It allows them to enter, if only in fantasy, a world entirely attuned to their manner of thinking, a world in which they can move about with certainty and in which nothing dark or frightening remains. Children see themselves all too often as imperfect, as being not in harmony with their true selves. They have to grow up, to develop, to gain knowledge, to practise new norms of conduct. In other words, children are required to become, permanently, another sort of being entirely. This is too often only a source of unhappiness. The children's literature of childhood autonomy - in both its Romantic and its realistic variants - gives children a sense of identity and of being no longer incomplete but rather with their own sense of wholeness. This is a feeling that our modern, grown-up society fundamentally denies children.

\section{Idyllic Children's Literature in the $20^{\text {th }}$ Century - Unjustly Underestimated and Rarely Treasured}

Children's non-fantastic literature of childhood autonomy draws from various European literary traditions beyond merely those of Romantic origin. European 
idyllic and bucolic poetry, which flourished in the baroque $17^{\text {th }}$ and enlightened $18^{\text {th }}$ centuries, is of particular importance. The country-rural settings of this style are still present in Brlić-Mažuranić's Hlapich story. Outside the realm of folk tales, Schwänke (amusing stories, farces) were also influential. The Kalendergeschichten (calendar tales) of the $18^{\text {th }}$ and $19^{\text {th }}$ centuries should also be mentioned. This form was brought to a high level of literary development within the German literary tradition by Johann Peter Hebel. I refer particularly to Schatzkästlein des rheinischen Hausfreundes [The Rheinish Family Friend's Treasure Chest] from 1811. The calendar stories were written for a rural population while the Dorfgeschichten (village stories) that arose out of this tradition were generally written for an urban population. This beloved genre of story-telling, which reached its height in Germany in Berthold Auerbach's Schwarzwälder Dorfgeschichten [Black Forest Village Stories] from 1843, also played a major role in children's literature. Finally, the genre of the parable is worth mentioning. Parables had already achieved importance in the Enlightenment in the $18^{\text {th }}$ century and were still beloved in the Biedermeier. The influence of this didactic genre is easily traceable wherever children's literature of childhood autonomy attempts to be morally instructive. The episodes of Hlapich also have an unmistakably morally instructive character: they want to convey exemplary instances of certain social and ethical norms and they do this in a way that will be entirely evident to children.

Looking at the above-named literary traditions, the type of children's literature of childhood autonomy that we are talking about reveals its partly idyllic, partly parabolic character. What the Brothers Grimm in one of their introductions claim for the fairy tale is even more fitting for this type of children's literature:

So einfach sind die meisten Situationen, daß viele sie wohl im Leben gefunden, aber wie alle wahrhaftigen doch immer wieder neu und ergreifend. Die Eltern haben kein Brot mehr und müssen ihre Kinder in dieser Not verstoßen, oder eine harte Stiefmutter läßt sie leiden und möchte sie gar zugrunde gehen lassen. [...] Der ganze Umkreis dieser Welt ist bestimmt abgeschlossen: Könige, Prinzen, treue Diener und ehrliche Handwerker, vor allem Fischer Müller, Köhler und Hirten, die der Natur am nächsten geblieben, erscheinen darin; das andere ist ihr fremd und unbekannt.

They say elsewhere:

Die Märchen also sind [...] dazu bestimmt, den reinen Gedanken einer kindlichen Weltbetrachtung zu fassen, sie nähren unmittelbar, wie die Milch, mild und lieblich, oder der Honig, süß und sättigend, ohne irdische Schwere [...].

As little as these sentences may fit European fairy tale literature, they nonetheless put forward a highly precise theory about the sort of children's literature considered here. 
The basic idea of an autonomous children's world, as developed in the $18^{\text {th }}$ and early $19^{\text {th }}$ centuries, by Rousseau and his primarily German followers on one side and by the Romantics on the other, did not survive in the $20^{\text {th }}$ century. Social and political conflict and class struggle, dictators and totalitarian systems, and finally the two World Wars, as well as other devastating wars, made a childhood free of burden and strife impossible. Towards the end of the $20^{\text {th }}$ century, the consumergoods and media industries affected all areas of life, subjecting childhood to widereaching commercialization. Thus, childhood was robbed of independence and light heartedness.

\section{Instilling a Basic Sense of Trust}

In my opinion, only the turn of the $20^{\text {th }}$ century and the time after 1945 , especially the 1950s and 1960s, can be considered periods when children's literature of childhood autonomy flourished in western European countries. It is no accident, then, that Hlapich was translated into German at the end of the 1950s. Indeed, Hlapich shows a decided similarity to the classic children's books by Otfried Preußler, especially his Räuber Hotzenplotz stories, which were being published contemporaneously. As beloved as the children's books of this recently deceased classic German author still are, they nonetheless seem to function like a message from a long lost era. This fits together well with my reading of Hlapich. Such light heartedness, such a whisking away from modern society, with all its conflicts, struggles, and wars, such a happy escape into a world of touching simplicity and straightforwardness!

In the 1970s, this form of children's literature was condemned as an illusionary pretence of a holy, and therefore false, untrue world. The only question that was still asked of children's literature was whether or not it accurately reflected reality. No one considered that this literature had never intended to assert anything about modern social realities. This children's literature aimed at nothing more than the imagining of a pure, poetic world, a world that would be perfectly aligned with the child's manner of thinking and feeling. It aimed to create for its young readers the feeling of a happy agreement between the self and the world. Admittedly, this literature also promoted virtues that now seem specific to an outgrown past and often depicted gender roles that have now become obsolete. Still, this does not affect the heart of the matter: this literature instils a basic sense of trust in its child readers, a trust that children are not easily able to achieve later. In German, this is referred to as Urvertrauen. The modern world is too volatile, too torn, too unruly, and too ambivalent to instil such trust. Whoever hopes to be able to bear the instability 
of modern life must establish a basic sense of trust during childhood, must gain an elementary belief in the good and the just. Not only mothers and fathers but also children's books, in the style of Hlapich, must share in the responsibility of instilling such a sense of trust in children.

Translated from German by Julia Reagen

\section{Hans-Heino Ewers}

Sveučilište "Johann Wolfgang Goethe”, Frankfurt - Institut za istraživanje dječje književnosti Johann Wolfgang Goethe Universität, Frankfurt am Main - Institut für Jugendbuchforschung

\section{Dječja književnost u Europi početkom dvadesetoga stoljeća i intelektualno mjesto dječje priče Čudnovate zgode šegrta Hlapića Ivane Brlić-Mažuranić}

Esej prikazuje kulturni kontekst $i$ ideje vodilje obrazovne reforme u Europi početkom dvadesetoga stoljeća te donosi pregled trendova prisutnih u dječjoj književnosti toga vremena. Autor smješta Čudnovate zgode šegrta Hlapića Ivane Brlić-Mažuranić, klasično djelo hrvatske dječje književnosti, u tradiciju ne-fantastične dječje književnosti dječje autonomije, dijelom idiličkoga, a dijelom paraboličnoga značaja. Također to djelo dovodi u vezu s pričama njemačkoga dječjega pisca Otfrieda Preußlera, koje su se pojavile sredinom dvadesetoga stoljeća, u vrijeme kad je Hlapić preveden na njemački jezik. Radi se o vrsti književnosti usmjerenoj na to da u mladim čitateljima stvori osjećaj sretnoga sklada između sebe i svijeta te tako u djecu čitatelje ugradi temeljni osjećaj: povjerenje.

Ključne riječi: dječja književnost, Europa, početak dvadesetoga stoljeća, Ivana BrlićMažuranić, Čudnovate zgode šegrta Hlapića

\section{Die Kinderliteratur in Europa zu Beginn des 20. Jahrhunderts und die Bedeutung von Ivana Brlić-Mažuranić's Kinderliteraturklassiker Čudnovate zgode šegrta Hlapića}

In dem Essay werden der kulturelle Kontext und die Leitideen zur Bildungsreform in Europa zu Beginn des 20. Jahrhunderts vorgestellt, sowie der damalige aktuelle Stand der Kinderliteratur umgerissen. Den kroatischen Kinderliteraturklassiker Čudnovate zgode šegrta Hlapića von Ivana Brlić-Mažuranić verortet der Autor in der Tradition der nicht-fiktionalen Kinderliteratur, wobei das Werk sowohl idyllische wie auch parabolische Merkmale aufweist. In dem Essay wird sodann das Werk in Beziehung zu den Erzählungen des deutschen Kinderautors Otfried Preußler gebracht, die um die Mitte des 20. Jahrhunderts veröffentlicht werden, als Hlapić ins Deutsche schon übersetzt war. In beiden Fällen handelt es sich um eine Art der Kinderliteratur, die darauf ausgerichtet ist, in den Kindern das Gefühl des Einklangs mit der Umwelt hervorzurufen und ihnen damit eine Form von Urvertrauen zu vermitteln.

Schlüsselwörter: Kinderliteratur, Europa, Beginn des 20. Jahrhunderts, Ivana BrlićMažuranić, Čudnovate zgode šegrta Hlapića 
UDK 792.01

821.163.42-93-31BRL:792.25

\section{Željka Flegar}

University of Osijek, Faculty of Teacher Education

zflegar@ufos.hr

\section{The Great Literary Improvisers}

Izvorni znanstveni članak / original research paper

Primljeno / received 25. 4. 2013.

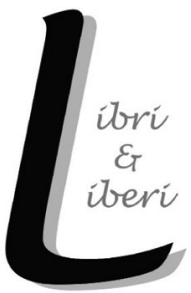

The paper discusses the principles and philosophy behind the art of improvising derived from the theory of improvisational theatre. The aim is to heuristically apply a typology of theatrical improvisation to the literary works of the Golden Age of Children's Literature in order to position the authors and the works of the Golden Age within the body, as well as to locate the Croatian 1913 classic Cudnovate zgode šegrta Hlapića [The Brave Adventures of a Shoemaker's Boy] by Ivana Brlić-Mažuranić within this defining era of children's literature. Due to the fact that improvisation is based on storytelling and that literature is reportedly conceived through images, this research aims to provide evidence that The Brave Adventures of a Shoemaker's Boy, much like the most prominent works of the Golden Age, is a superb example of the improvisatory process characterized by "bodily poeticizing" as defined by Lockford and Pelias (2004). The result of this creative process is the endurance, universality and adaptability of the works of the Golden Age, such as The Brave Adventures of a Shoemaker's Boy. Ključne riječi: archetype, bodily poeticizing, Golden Age of Children's Literature, improvisational theatre, literary pragmatics, realistic fiction, The Brave Adventures of a Shoemaker's Boy

\section{Improvisatory Images}

The nature of the origins of art, inspiration and imagination has been discussed for centuries. In her book The Art and Craft of Storytelling (2008), Nancy Lamb claims, "There is a mystery to writing. There is magic. Not in how we get our creativity, but how we use it. There is an element of surprise - of ideas appearing out of nowhere and connections leaping out of dreams - that cannot be accounted for in the daily living of our lives" (245). 
Similarly, the theory of theatrical improvisation, built on the foundation of commedia dell'arte, and further developed in the mid-twentieth century in the United States and Great Britain by Viola Spolin and Keith Johnstone, assumes that all inspiration and creation comes from initial spontaneous impulses and not deliberate reflection and contemplation: "[a]n artist who is inspired is being obvious. He is not making any decisions, he's not weighing one idea against the other. He's accepting his first thoughts" (Johnstone 1989: 88).

It is no surprise, then, that C.S. Lewis describes the origins of Narnia beginning with an image of "a Faun carrying an umbrella and parcels in a snowy wood" (Sammons 2004: 23), that J.R.R. Tolkien's work began on an empty page while Tolkien was grading his students' papers and spontaneously wrote the first sentence of The Hobbit (Carpenter 1977), that Baum got the idea for The Wonderful Wizard of $\mathrm{Oz}$ "right out of the blue" (McMaster 1992: 103) or that J.K. Rowling was sitting on a delayed train ride to London when "the idea of Harry Potter simply fell into my head“ (Rowling 2012).

In much the same way, Ivana Brlić-Mažuranić, one of the greatest Croatian children's authors, was inspired by the juxtaposition of a cheerful apprentice and his grumpy master that she encountered at a fair in Slavonski Brod, which resulted in Čudnovate zgode šegrta Hlapića, published in 1913 [The Brave Adventures of a Shoemaker's Boy] ${ }^{1}$ (Mihanović-Salopek 2001: 121). This Croatian classic about an orphan apprentice who sets off on a journey to break in the little boots that he had made too tight and do good deeds has been a source of wonder and inspiration for an entire century, resulting in numerous translations and adaptations on page, stage, radio and screen. ${ }^{2}$ The novel, much like its contemporaries of the Golden Age of Children's Literature, was conceived in the body and exhibits the obvious elements of improvisational behaviour, communication and perception.

Accordingly, "bodily poeticizing" as a typology (Lockford and Pelias 2004) will be used as a heuristic device to illustrate the shift towards the body which occurred during the Golden Age of Children's Literature, as well as to position The Brave Adventures firmly within this context as one of the classics of the Golden Age.

1 This paper uses the English translation by Theresa Mravintz and Branko Brusar, published in 1971. The name of the protagonist, Hlapić, is given as "Lapitch" in this edition. Other Croatian translations of the title include The Strange Adventures of Hlapich the Apprentice and The Brave Adventures of Lapitch, the latter being the title of the American edition which appeared in 1972.

2 Brlić-Mažuranić adapted the novel into a play (Lovrenčić 2006: 152, 259-94). Contemporary stage productions include those by Croatian children's and puppet theatres (Kazalište Trešnja and Gradsko kazalište Žar ptica in Zagreb, Dječje kazalište Branka Mihaljevića in Osijek, Kazalište lutaka Zadar). In 1967 and then in 2006 different radio plays based on The Brave Adventures were premiered on HR (Croatian Radio), in 1997 Croatia Film produced the animated film Lapitch the Little Shoemaker, and the latest live action feature titled Šegrt Hlapić directed by Silvije Petranović was released in 2013. 
The proposed typology which "relies upon the affective, physical, and vocal capacities of the performer" (Lockford and Pelias 2004: 432), signifies "thinking, intuiting, and feeling... with the body" (Roloff, qtd. in ibid.), and specifies "the performer's body as a site of knowing", while emphasizing the "act of doing as a way of coming to understand" (Lockford and Pelias 2004: 432), implies that the author, the literary product and the reader are inseparable entities, under the assumption that the sentiment and the personality of the author are largely reflected in the work of fiction and reconstructed during the process of reading.

The proposed methodology derived from improvisational theatre "privileges the sensuous, the experiential, the participatory" (ibid.). These also describe the features of children's literature that became apparent for the first time during the Golden Age, which distanced itself from didacticism and discipline prevalent in earlier works written for children. The Golden Age, because of the shift towards the body and its surroundings, became the point of origin for the terms 'childhood' and 'children's culture' as they are understood today. This analysis will, therefore, focus on the improvisatory "epistemic stances" of communication with which the author endows his or her characters and addresses the reader, on the playfulness and sedimentation characterizing the protagonist, the author and the reader who do not settle for literary lessons, but actively participate in the literary experience (albeit in an 'improper' fashion), as well as on the sensuality and vulnerability in the bodily perception of the internal processes, the environment and the regional subject matter. The listed categories will be presented by means of examples from The Brave Adventures of a Shoemaker's Boy by Ivana Brlić-Mažuranić in the context of the most prominent international works of the Golden Age of Children's Literature. As such, bodily poeticizing becomes a way of illustrating the childlike in the literary process of creation and reception which emerged during the Golden Age, as well as positioning one of the greatest Croatian children's classics within this context. By means of the proposed improvisational theories, the journey of the heroes of the Golden Age will be displayed as an improvisatory bodily process which changed the nature of writing for children. Finally, it is because of the shift in literature towards the body that the works of the Golden Age persevere, remain present as both regional and universal masterpieces, and are continually resurrected in the media.

\section{The Golden Age}

Although the nineteenth century was marked by poverty, unsanitary conditions, social neglect and mistreatment of children, it also marked a radical change in 
how children were perceived. Due to the Factory Acts, which limited child labour, the Education Acts, which raised the school leaving age, and medical discoveries which reduced infant mortality, the momentum leading to what is now known as a Golden Age of Childhood was developed (Messenger Davies 2011: 27). As a result, children were recognised as human beings extending beyond the image of small adults (Rogers 2008: 41), in other words, a group of individuals and consumers with a specific artistic taste and preferences. Accordingly, the Golden Age of Children's Literature began approximately in the mid-nineteenth century and continued up to the First World War (Hunt 2012; Messenger Davies 2011: 134).

This period constituted a true blossoming of children's books which for once did not aim to educate or patronize, but to properly entertain (Hunt 2012). In other words, the beginnings of children's literature offered religious and didactic materials aimed at children, such as hornbooks and primers, and although fables, fairy tales or novels such as Defoe's Robinson Crusoe (1719) were available to children, such texts were either used to indoctrinate, or were not intended for, aimed at or considered desirable for children (Zipes 2005: 175; Kinnell 1995). Consequently, during the Golden Age a significant shift was made from literature which targeted the lesson and the intellect, ${ }^{3}$ towards a type of literature which was produced primarily for children's enjoyment and was located in the bodily experience. As Hunt claims, "[ $t$ ]he most common view of the history of children's literature is that the books have progressed steadily from didacticism to freedom, or from strictness to corruption" (1995: xii).

Thus, the Golden Age put "some of the most influential, honest, and lasting children's stories into print" (Tunnel and Jacobs 2008: 45) such as Lewis Carroll's Alice's Adventures in Wonderland (1865), Hans Christian Andersen's Fairy Tales Told for Children (1835), Carlo Collodi's The Adventures of Pinocchio (1881), Mark Twain's 'bad boy' novels The Adventures of Tom Sawyer (1876) and The Adventures of Huckleberry Finn (1884), ${ }^{4}$ J.M. Barrie's Peter Pan (1904) and Frank L. Baum's The Wonderful Wizard of $\mathrm{Oz}$ (1900). The Golden Age thus implies international children's literature and works published in the Western World in the period between the mid-nineteenth century and the First World War, showing many

E.g., "When the Sun doth arise, you must get up each Day, / And fall on your Knees, and to God humbly pray; / Then kneel to your Parents, their Blessing implore; / And when you have Money, give some to the Poor. / Your Hands and your Face, in the next Place, wash fair; / And wish a good Morning to all in your View, / And bow to your Parents and bid them adieu" (Nurse Truelove's Christmas Box, c. 1750, qtd. in Avery 1995: 6).

${ }^{4}$ Children's literature scholars, including Hunt in Children's Literature - An Illustrated History (1995), place The Adventures of Huckleberry Finn within the children's literary canon. The characterization and the indigenous character of the novel make this work particularly suitable for comparison with Ivana Brlić-Mažuranić's book. 
similar features and trends characteristic of the period. Scholars claim that the Golden Age was an era of transition and change of which people were consciously aware and to which children's books wholeheartedly responded (Hunt 2012; Helson 1974: 68). Likewise, this period produced one of the most significant works in Croatian children's literature, namely The Brave Adventures of a Shoemaker's Boy by Ivana Brlić-Mažuranić.

\section{The Journey, Improvised}

Hlapic, ${ }^{5}$ the main protagonist of the novel, is a shoemaker's apprentice who, after having been mistreated by Master Scowler on account of boots which were made too small, runs away into "the wide world" (BASB": 14). Similarly, the Golden Age of Children's Literature features numerous journeys or quests, the structure of which ranges from conventional to nonsensical, often characterized by the act of running away, rebellion or displacement under circumstances beyond one's control. Dorothy, the Scarecrow, Tin Woodman and Lion are on their quests for home, brain, heart and courage, respectively; Huck travels "on the river and away from the corrupt society" (Goldman 2010: 4); Andersen's Gerda crosses the country in pursuit of her beloved Kai; and Alice's journey underground touches the part of ourselves that "has been beneath sight" (Stowell 1983: 8). Hlapić's encounters the man in black - his antagonist - and his homelessness and the constant change of place and environment are not unlike Alice's changes in size, reversals in logic or obliteration of time (Suchan 1978: 88). While on their quest for identity, conceivable adulthood and home, the heroes of the Golden Age, whether on their way to reach a mysterious garden or "lighting out for the territories" (McGillis 1983: 19), "must deal with events as they occur" (Moynihan 1973: 166-167) in an improvisatory process of "making stuff up as you go along" (Napier, qtd. in Zaunbrecher 2011: 49). In order to more closely define this type of journey as an improvisatory and bodily process, it will be observed in the light of the above-mentioned improvisational theories derived from the art of theatrical improvisation.

The journey of the little apprentice, much like that of his contemporaries, is distinctly archetypal. Though The Brave Adventures belong to the genre of realistic fiction, they equally contain layers of the universal. Jung defined archetypes as "primordial images" (2010: 12) which are inherent to the human psyche and common to all human experience, and whose most important application is in creative fantasy in which they are made visible (12-13). The main protagonist,

\footnotetext{
5 The main protagonist of the novel is referred to as Hlapic (original), Hlapich or Lapitch, depending on the translation. The author of this paper opted for the original version. See footnote 1, too.

${ }^{6}$ BASB refers to the 1971 English edition of The Brave Adventures of a Shoemaker's Boy.
} 
Hlapić the Apprentice, is a child archetype "who had neither father nor mother" (10), and who, much like Huck Finn, is on the threshold of adulthood in pre-war times (cf. Prusak 2011: 5). According to Berislav Majhut, an orphan as the protagonist of a children's novel adopts a position which is lower and less powerful than that of the intended reader; such a character is excluded from society, and passively suffers the blows inflicted by fate, until someone comes to the rescue (2005: 119-122). However, according to Martin, the lack of parental supervision makes characters open to journeys or quests in order for the protagonists to find their place within their community (2002: 16). This search for identity and restoration of the natural order includes many obstacles and perils which make it easier for an orphan to adopt the role of hero and undertake the quest and with which the reader can gladly identify.

Beckwith, for example, claims that "in no other American children's books do there seem to be so many orphans" (1976: 84-85) as in the Land of Oz series, and Alice and Peter Pan are dreamchildren whose stories fit within "a realm of literature which stares unblinkingly at the truth, which strides over flaws and inconsistencies, over the intellectual and social forces of our time, straight into the collective mind of its audience" (Rose, qtd. in Billone 2004: 181) and Pinocchio partakes in the "more inclusive process of becoming human" (Bettella 2004: 5). It is the confusion pertaining to the origins and search for clarity and order that propels the orphan on his or her quest.

Improvisational theatre, likewise, relies on the archetypal, having first appeared within the oral tradition of storytelling. Therefore, the primary goal of ancient improvisation, commedia dell'arte or the contemporary art of improvisation has been and is to tell stories. While establishing the theory of bodily poeticizing, Lockford and Pelias draw parallels between the act of improvisational performance and the process of creating a literary text, thus (Lee, qtd. in Lockford and Pelias 2004: 432):

The call to write is a call that is received in the body first. For hundreds of years poets and writers have described the creative process as a physical urgency, a sense that things will fly apart if they don't get the pencil to the page in time. Creativity is not tidy or polite - it's insistent. It calls us to feel, not dimly, not safely but wildly, passionately, in every cell and fiber.

Bodily poeticizing, in other words, is "a process of aesthetic engagement and judgement located in a corporeal presence" (Lockford and Pelias 2004: 432) and within this analysis it implies the authors, their fictitious products, and the participation of the reader. Although this typology is normally applied to actors who spontaneously create stories on stage, in this instance it is a lens through which one might observe the literary process of inspiration, creation and reception. In Literary Pragmatics, Mey discusses the relationships within literary discourse, thus (2003: 794): 
In the traditional view, authors create a text by inventing some characters, who then proceed to act out some series of events, called 'stories.' The characters are the author's 'creatures': we attribute the creational origin of a particular character (e.g. Huckleberry Finn) to its creator, a particular author (here Samuel Clemens, a.k.a. Mark Twain).

Accordingly, bodily poeticizing displays author-character-reader relationships through images which the author uses to build characters and which are then through images vicariously enacted and interpreted by the reader, accounting for numerous adaptations of the novels of the Golden Age for stage, radio, film or digital media. As Mey further notes (788):

The reader, as an active collaborator, is a major player in the literary game. His or her contribution consists in entering the universe that the author has created, and by doing so, becoming an actor, rather than a mere spectator. As a result, we do not only have cooperation, but also innovation. By acting the reader changes the play: what the reader reads is, in the final analysis, his or her own coproduction along with the author. I call this interaction a dialectic process..., inasmuch as the author depends on the reader as a presupposition for his or her activity, and the reader is dependent on the author for guidance in the world of fiction, for the 'script' that he or she has to internalize in order to successfully take part in the play...

Therefore, literature as an embodied experience at the levels of production and reception responds to the typology of bodily poeticizing comprised of the key epistemic stances of communication, playfulness, sedimentation, sensuality and vulnerability. Furthermore, the theory of theatrical improvisation deals with the spontaneous aspect of the performance, which at the same time must adhere to the structural determinants. All good improvisers are first of all noted craftspeople and professionals, and bodily poeticizing, therefore, encompasses the "embodied, cognitive, affective, and intuitive locations of [performance-derived] knowledges" (Lockford and Pelias 2004: 432) which constitute the creative pull similar to that of a writer (Lee, qtd. in Lockford and Pelias ibid.). According to Jackson, the defining characteristic of the character of Huckleberry Finn, who was created "in idle amusement in the summer of 1876", as "the freewheeling mixture of burlesque, satire, tall tale, and many other improvisations of technique and purpose" (Quirk 2012: 39), is "his industrious improvisation in any situation before him" (Jackson 2002: 60). Similarly, Alice spontaneously eats and drinks strange food and beverages, changes size, and repeatedly enters unknown spaces while attempting to communicate with the strangest folk she had ever encountered. As Carroll himself noted (qtd. in Helson 1974: 72-73):

I distinctly remember, how, in a desperate attempt to strike out some new line in fairylore, I had sent my heroine straight down a rabbit-hole, to begin with, without the least idea what was to happen afterwards. 
Examples of the improvisatory process are numerous in the emerging literature for children, and one of the most exquisite is The Brave Adventures of a Shoemaker's Boy. The following analysis demonstrates Hlapić's "epistemic stances" (Lockford and Pelias 2004: 432) of improvisatory communication, behaviour (playfulness and sedimentation), and perception (sensuality and vulnerability) in relation to his surroundings and those of his contemporaries, as features which became apparent for the first time during the Golden Age of Children's Literature.

\section{Improvisatory Behaviour or Worlds of Play}

Produced in 1904, the play Peter Pan, or the Boy Who Wouldn't Grow Up was a model of nineteenth century English pantomimes which was composed of fantastic effects, magic, flying, humour, harlequin clowns (Billone 2004: 187-188). According to Billone, in Barrie's world children are endowed with three skills which adults do not possess (191):

1) they can enter their own dreams and make these dreams come true, 2) they can play fantasy games in which the imaginary world takes the place of concrete reality; 3 ) they can fly (with the help of Pixie Dust and happy thoughts).

In accord with Twain's definition that "work consists of whatever a body is obliged to do, and that play consists of whatever a body is not obliged to do" (2005: 17), playfulness became the feature found in the most prominent works of the Golden Age for the first time ever, bringing "the pursuit of pleasure for its own sake into children's books" (Helson 1974: 72). Therefore, Alice's Adventures in Wonderland and its sequel Through the Looking-Glass, and What Alice Found There (1871) feature a series of games in which the rules of adult society, such as etiquette, education, edicts of law, rules of language and literary convention, are broken (Scott 1990: 21), but which have their own rules to follow, as is evident from the unusual treatment of croquet, chess, and card games.

Playfulness as a part of bodily poeticizing signifies opening oneself up to one's body's “expressive potential", being spontaneous, imaginative and ready to explore (Lockford and Pelias 2004: 434-5). Opulent with surprises in the choices that performers make, it is the "playfulness, the energizing and enabling fear, the search for consistency and the desire to respect co-actors" (436) that guide the performer or, in a novel, the character towards the completion of their task, which is indeed present in Brlić-Mažuranić's treatment of characters in The Brave Adventures of a Shoemaker's Boy. Not surprisingly, Ivana Brlić-Mažuranić reported that "when my small band of children began to grow and when they began to want to read, I felt at once that here was where inclination and duty became one, for I longed to be a writer“ (BASB: 7). 
Hlapić displays playfulness in his attitude and appearance as he prepares for the journey by putting on a pair of beautiful little boots, his green trousers, red shirt and shiny cap (BASB: 14), causing reactions such as, "My, what a sight you are! Are you a parrot or a woodpecker?" (19-20). Later on, the appearance of this little band of an unusually clad boy, his dog Bundash, Gita the circus girl that they encounter on the road and her parrot "makes an impression" (69) everywhere they go. This companionship proves to be on some occasions quite useful, as in the case of the merry-go-round owner who "thought they looked exactly right for the work and immediately took them on" (82). The companionship of child assistants or the pairing of protagonists is very common in novels of the Golden Age and constitutes the mythological dimensions of a narrative, such as the company consisting of the archetypal relation between Power, Knowledge and Love in The Wonderful Wizard of $\mathrm{Oz}$ (McMaster 1992: 106). As the child archetype often displays an androgynous character which symbolizes the potential merging of the opposites (Helson 1974: 72), the pairing of Hlapić and Gita is a common literary combination.

Gita, who is also an orphan, represents the Trickster, or the angelic, mischievous and idle counterpart to the industrious and sacrificing Hlapić, and encompasses mercurial trickster motifs such as a "fondness for sly jokes and malicious pranks, his powers as a shape-shifter, his dual nature, half animal, half divine, his exposure to all kinds of tortures, and - last but not least - his approximation to the figure of a saviour" (Jung 2010: 135). Up until the Golden Age when characters such as Tom Sawyer or Peter Pan were unleashed, mischief was not an integral part of children's texts. The stubbornness and aggression typical of children's behaviour appeared in English literature only at the end of 18th century in, for example, Mary Ann Kilner's Memoirs of a Peg-Top (c. 1781) and The Adventures of a Pincushion (c. 1780) ( $c f$. Avery and Kinnell 1995: 54). As a circus performer, Gita embodies the trickster tradition of Fools Holiday festivals celebrated in Middle Ages which were historically replaced by commedia dell'arte (138-140). Therefore, while listing her professional credentials, Gita prides herself on being able to "stand up on a horse and make it jump through a hoop", "juggle with twelve apples at a time", and "bite through a thick glass tumbler and swallow the pieces" (BASB: 38). She is lazy, easily bored (40), "trained for hoops and tightropes just for the sake of hoops and tightropes" (44). Yet, she manages to plot a scheme to punish the rich and boastful basket-maker at the fair and earn extra money for the poor one who had many children to feed, and though Hlapić "would never have played a trick like that himself [...] he laughed so much that his bag shook on his back" (79), whereas the poor basket-maker "thought she must be an angel sent from heaven to help him" (80). Much like the ambiguous Wonderland trickster the Cheshire Cat who is "good 
natured" but "has very long claws and very many teeth" (Stowell 1983: 7), which renders this character kind and dangerous at the same time, Gita has two sides. She is on the one hand nice, sensitive and compassionate, and on the other hand spoilt, at times selfish, and complicated. She slows Hlapić down and resists hard work, yet she is also sharp-witted and the source of ingenious ideas regarding survival, such as suggesting that Hlapić mend the herders' sandals so that they might spend the night in their house (BASB: 69), or entertaining the labourers during haymaking (42-44).

Though he might proceed on his journey faster without her, Hlapić does not abandon Gita because the Trickster represents growth, "is always present in the transformative journey, and his ultimate effect is positive; in fact, the presence of this ambivalent energy is crucial for change" (Stowell 1983: 5). It is noteworthy that Ivana Brlić-Mažuranić created the idle circus girl with particular tenderness and care, as if she were the love child of her most intimate thoughts. Brlić-Mažuranić's "lively and playful disposition" and her affinity for theatre are mentioned both in her autobiography, and by her biographers (Lovrenčić 2006: 152, 259-294). Therefore, Gita's previously unrehearsed performance for the labourers during haymaking is the most prominent example of playfulness and performing arts in the style of street theatre, circus and the tradition of commedia dell'arte. Gita appears as "the most dazzling sight", "like a queen in her golden dress, her hair streaming over her shoulders" in a little cart "that had held the drinking-water", all decorated, with Hlapić's dog Bundash pulling it, adorned with "a wreath of flowers round his neck and red bows on his tail" and "a pole was tied to the front of the cart and from a ring attached to this swung the parrot" (BASB: 42). Gita "spun like a top and hopped like a bird and beat a little drum", jumped through hoops "as easily as a fairy" (4243), walked the rope, sang "a strange kind of song which only circus people and parrots understand" (44) and managed to prepare the animals for the performance. While the audience is so full of admiration that "they were forgetting to eat their beans and potatoes", Hlapić, the author and the rest of us realise that it was quite "wonderful for Lapitch to share his journey with a friend who was wise and good in joy and in need!" (42). This playfulness permeates all that happens in The Brave Adventures, it is the reflection of the author's nature and is the source of images that engage the reader and viewer even today.

Throughout the novel, characters likewise display the skill of sedimentation. An improviser would describe sedimentation as an inexplicable moment in which they made a choice that they themselves could not comprehend, in other words "it just felt right" (Lockford and Pelias 2004: 436). Zaunbrecher considers this spontaneity a "primary feature of any improvisational performance act" (2011: 50). Sedimentation, according to Lockford and Pelias, implies the process in which 
performers "seek somatic signs, follow hunches, and trust impulses" (2004: 437). Possibly it is for this reason that Alice dares to taste the strange and the unknown, Huck befriends Jim despite the norms and expectations of his community, and Gerda knows that Kai is not dead.

In The Brave Adventures, Hlapić as a character makes intuitive decisions that significantly affect the course of events. The most prominent example of sedimentation is Hlapić's act of climbing up on the roof of a village house to put out the fire on the "fourth day of the journey" (BASB: 47-57). The act constitutes a decision which "responds to [the] immediacy" of the situation (Spolin, qtd. in Lockford and Pelias 2004: 436). The situation is described in the novel like this (BASB: 49):

Everybody looked up and there sat a little figure, wearing green trousers, a red shirt and a coloured cap. Some of you would have thought it was a fireman. But of course it was Lapitch who had scrambled up there while the people were wasting time quarrelling.

What follows this act is Hlapic falling through the roof into the loft which "really was a miracle" (51), as he falls into a bin of flour and subsequently finds in the loft all the stolen items he had been searching for, including the beautiful little boots which the man in black took during the storm (51-52). Therefore, a potentially fatal event brings Hlapić closer to justice and the fulfilment of his own desires, evident in the scene in which "[t]hey picked up Lapitch out of the flour and carried him shoulder-high to the courtyard. Nursing his precious boots, he felt as happy as a king" (52). It is conceivable that Brlić-Mažuranić's practice of telling stories to her own offspring resulted in the creation of characters who spontaneously contribute to the circumstances arising. The resourcefulness of such characters became the staple of child characters as we know them today. While following them on their journey, a child reader not only learns, but also participates in a lifelike bodily adventure.

\section{Improvisatory Communication}

Lockford and Pelias deem communication fundamental to any performance (2004: 433). Due to the fact that they adopt Burleson's definition of communication as "a process of message production, message reception and interactional coordination" (Lockford and Pelias 2004: 433) in which performers are encouraged to "listen carefully to each other to be open to what is being said", in other words "accept offers" and avoid "blocking" (Johnstone 1989; Wirth, qtd. in Lockford and Pelias 2004: 433), improvisational communication implies coordination and negotiation, adapting to the circumstances arising and drawing on the performers' 
cognitive, affective and intuitive skills. Offers in improvisation are verbal, nonverbal, intentional or unintentional cues received from the environment to which the performer needs to respond with urgency in order to shape their own reality. In doing so, however, the performers must at all times follow linguistic rules and the conventions derived from the game structure. Such is the case, for example, in Alice's Adventures in Wonderland in which superficially all rules of logic are broken, yet Carroll as a scholar is able to create wordplay and nonsense precisely because he is exactly aware of the rules of the game.

Likewise, playful exchanges as a reflection of the author's nature ${ }^{7}$ are present in The Brave Adventures of a Shoemaker's Boy, though not in the least in an anarchic manner. They retain the essential benevolence, clarity and simplicity which permeate the entire novel, as, for example, when Hlapić asks the milkman "why such a clever animal should be called a donkey or an ass" (BASB: 21) or when he tells Yana the beggar that "the emperor has sent me on a journey through this country to give help where help is needed" (72-73) which was "nonsense of course but it made old Yana laugh and Lapitch started on her sandals right away" (73). Furthermore, Gita's trickster nature shines out when to Hlapić's "Here's the donkey!" she retorts "Did you mean yourself?" (118).

Most importantly, communication as a vehicle of trust, support, cooperation (Izzo, qtd. in Lockford and Pelias 2004: 434) and respect is the chief marking of The Brave Adventures. Brlić-Mažuranić's omniscient narrative voice speaks directly to the reader in a manner of the oral tradition of storytelling and most likely as a result of her rapport with her own children. She does indeed tell of the olden days, when "people used to tell stories about elves and witches and vampires meeting at crossroads" (BASB: 58) and even lets Hlapić retell the tale of "The Princess and the Pea" (84-85). Further examples of her storytelling discourse include "This was the first day of Lapitch's travels, and it had a happy ending. What would the next day bring?" (28), "It was a happy evening so it is worth telling it in full, although it is not otherwise important. For most people the cheerful things are the most important, anyway" (41) or "Well, if you've read this book so far and if you're fond of Lapitch perhaps you'd better close this book now and wait until tomorrow!" (102). Brlić-Mažuranić also displays much tenderness and respect for her main protagonist, as is obvious from her statements, "How kind and good Lapitch was and what a long way he had to tramp on his little feet!" (BASB: 94), "But Lapitch was a poor child and poor children get to know the whole world" (92).

In Searching for Ivana (2006) Lovrenčić describes Ivana Brlić-Mažuranić as an extremely sociable individual who enjoyed company and participation in various social events 
The authorial voice is reflected in the character because Hlapic employs most of the features of improvisatory communication. He treats the people that he encounters on the road, his companions, and even his enemies, with respect. Because he easily picks up cues from his environments, he offers help to the old milkman, helps Marko find his geese, communicates with the stone-breakers in such a manner that they conclude, "Your boots are good and you've just proved you have strong hands and a clever head" (BASB: 31-32). He also cooperates with his dog Bundash, which is why "For every piece he put in his own mouth he threw one to Bundash, who caught it in the air and swallowed it in one gulp" (2324). Consequently, Hlapić approaches people spontaneously, such as Gita, "I'm on a journey, too [...] So let's go together" (38) or a farmer, "Could you use good workers?" (39). By communicating freely with the people he encounters, Hlapić obtains valuable information needed to continue his journey. By showing respect and support for his fellow creatures, such as warning the man in black's accomplice Gregory on behalf of his mother (53), Hlapić affects a number of events which bring about a transformation of characters such as Gregory and Master Scowler, as well as the restoration of the natural order, family and identity, which supports the notion (Ornish, qtd. in Ryan Madson 2005: 123) that:

[...] we are creatures of community. Those individuals, societies and cultures who learned to take care of each other, to love each other, and to nurture relationships with each other during the past several hundred thousand years were more likely to survive than those who did not.

It is no surprise, then, that works of the Golden Age, such as The Brave Adventures of a Shoemaker's Boy, became the model and inexhaustible resource for children's literature as we know it today.

\section{Improvisatory Perception}

Ivana Brlić-Mažuranić was a keen observer of her surroundings ("Put, istina i život Ivane Brlić-Mažuranić”). Born in picturesque Ogulin, which nourished her imagination to such an extent that it made her contemplate "images and fantastic possibilities long into the night" (Brlić-Mažuranić 1916), and then moving to Karlovac, Zagreb, and eventually to Slavonski Brod, where she spent the remainder of her life, Ivana Brlić-Mažuranić experienced both the flair of the city and the sensory input of the country so evident in her work. While creating The Brave Adventures of a Shoemaker's Boy, Brlić-Mažuranić wanted to achieve "the simplicity and clarity of language", the result of which was a surprise: "the character of little Hlapić emerged from this book sweeter and clearer than he was in my thoughts" (Brlić-Mažuranić 1916). 
Accordingly, the improvisatory features of sensuality and vulnerability correspond to the author's sentiment and determine the mood of the novel. Augusto Boal encouraged actors to "feel what they touch, to listen to what they hear, and to see what they look at", which is why "this bodily sensitivity, this sensory alertness, this physical presentness is a source of knowledge that fuels the dynamic of an improvised moment" (Lockford and Pelias 2004: 437). The sensory and perceptual feature of children's literature was clouded in the period prior to the Golden Age by the need to teach and promote obedience. As opposed to that, the authors of the Golden Age freely made use of sensory images from their immediate surroundings, possibly under the influence of the Romantic movement. In Searching for Ivana, Sanja Lovrenčić relates Ivana Brlić-Mažuranić's first encounter with the magic of writing after she had been told by her teacher that "a sentence can contain the world" whereupon, in the quoted words of the novelist herself, "examples started flowing like a deluge from my new forge [...]. These pictures tossed into a sentence kept bouncing back off the paper like an imprint into my mind and - my first literary work was done!" (2006: 54). Brlić-Mažuranić's descriptions of the surroundings and natural phenomena are very simple, yet extremely sensory, such as "It was a hot, sultry day and a storm was brewing" (BASB: 32), or "Their road lay amongst vast meadows, like a long piece of straw laid across a green sea, and Lapitch and Gita walked along the road like two ants along the straw" (58). The countryside spaces come to life through the depictions of precious moments, such as (48):

Never in his life had Lapitch slept as well as he did that night. It is lovely to sleep on hay in the summer. The hay smells wonderful, everything is peaceful, nobody is awake. In the country all good people sleep at night. Only owls and bats are about and even they fly silently. They could not wake up Lapitch.

Finally, emotions spring forth in descriptions such as "The joy seemed to flood the room with golden light" (BASB: 113), which reflect both the author's style and output, as well as the condition of the protagonists.

Likewise, The Brave Adventures of a Shoemaker's Boy very successfully depicts the setting in which it was created, as the author captures the essence of her native and domicile regions. As a realistic novel, The Brave Adventures of a Shoemaker's Boy respects the laws of its universe, a characteristic of realistic fiction, and portrays the country landscape where "many carts and peasant folk passed by on the road. The carts creaked, the horses' hoofs clattered, the people shouted to one another and the geese that were being carried to market quacked and hissed" (BASB: 23). This is a place where "there was such a lot of noise that Lapitch woke up, and at first he thought he must be in a menagerie. In a village there is always this kind of noise in the morning, but he did not yet know that" (30), 
where "soon he could not see a single house anywhere - only vast fields, bushes, trees and the long road stretching out in front of him" (22). Brlić-Mažuranić very faithfully illustrates Hlapić's encounter with the stone-breakers (30), the labourers, villagers putting out a fire (48) and herders. In the course of the story, Hlapić and Gita also arrive in a large town (74):

It was so big that it had a church with two steeples and ten small ones with one steeple each. It had a hundred streets and people milling around them like ants.

The author shows the size of the town by means of the description of a large fair, at which (74):

there were two hundred stalls, large and small. You could buy red handkerchiefs, black coats, blue pottery and yellow melons. There was a great beating of drums and shrilling of whistles because many people were buying toys as well.

According to Beckwith, the "native" or "indigenous" subject matter (1976: 76) is the essential ingredient of the novel and the reason for its vitality, also present in other works of the Golden Age, such as the first American "fairy tale" The Wonderful Wizard of $\mathrm{Oz}$ and the "Great American novel" The Adventures of Huckleberry Twin, as well as in The Adventures of Pinocchio (1881), "one of the best novels in Italian Ottocento narrative" which "best expresses the Italian character" (Bettella 2004: 4). More than anything, it is the author's relationship to the region that is the constant source of wonder, amusement and "emotional reality" (Jackson 2002: 47).

Moynihan claims that stories told or written for children often represent the dominant values of a society (1973: 166), a feature which became very distinguishable during the Golden Age (Hunt 2012). Thus, Alice struggles with Victorian rules and Huck Finn contemplates the institution of slavery. In accord with that, Ivana Brlić-Mažuranić's novel neatly depicts pre-war Croatia on its way towards a transition between countries and identities, as she concludes in her "Autobiography" (1916):

Which of us knows his soul well enough to foretell how it will emerge from such trials, how it will be transformed, which sentiments will evade it, and which, thus far inconceivable revelations, will occur once we've suffered through this period.

We shall combine at this point the stance of sensuality and vulnerability for the purpose of describing the culmination and the final stage of the quest, namely the scene in the woods. Natural weakness and acceptance of failure appeared during the Golden Age as child protagonists began displaying natural child behaviour, in contrast to their predecessors who strived for perfection and heavenly reward. As Hlapić and Gita, towards the end of the novel, begin their journey at night in order to warn Marko and his mother in the house with the blue star painted on it that the 
man in black was coming to steal their cow, they encounter a setting of extreme vulnerability, described in the following way (BASB: 95):

Walking through meadows in the middle of the night is like walking in a dream. Big night-moths flew past their heads beating their wings like birds. Gita saw an old hedgehog trotting beside them on the grass, and now and again in the meadows they caught a glimpse of hares' ears sticking out of the grass. They heard birds rustling in the bushes.

Vulnerability in The Brave Adventures is manifested in homelessness and a lack of protection characteristic of an orphan. In improvisational theatre "when the actor experiences vulnerability, he may be gripped by a kind of imaginative stumping. The actor is thrown out of the scene and posed with the challenge to either break or remake the scene" (Lockford and Pelias 2004: 438). The stance of vulnerability does not necessarily need to lead to a breakdown, but may in fact be productive and cause the revitalising of one's own position, in other words, lead the performer in a new unanticipated direction. Most of the heroes experience a state of vulnerability, such as Dorothy and Alice in unknown lands of self-doubt (McMaster 1992: 104), Gerda who exposes herself to the forces of nature because of her "own failure to mourn" (Weitzman 2007: 1116), Huck whose arguments "fall on the wrong side" (Goldman 15-16) or Peter Pan who cannot bring himself to grow up. Likewise, all of them reinvent themselves from vulnerable circumstances, including Hlapić who tells Bundash, upon the stealing of his boots by the man in black (BASB: 36 ):

We'll look for him, Bundash, and we will find him if it takes us ten years! And we'll get the boots back, even if he hides them in the emperor's chimney!

The villain named "the man in black" is an archetypal figure which Clarissa Pinkola Estés, in her celebrated book Women Who Run With the Wolves, defines as "the natural predator of the psyche" who often appears as a "universal initiatory dream among women" (1995: 67). This character is the epitome of all evil in Hlapić's world, the original villain who "laughed as evilly as only bad men can laugh when they talk about their wicked deeds" (BASB: 92). Therefore, the conquering of the man in black signifies the restoration of the natural order, transformation and selfdiscovery. In this way, the images found on the pages of The Brave Adventures indicate a transformative journey. Though Hlapić indeed finds the boots, the man in black continues to commit evil deeds, one of which brings the children into the thicket at night. Interestingly enough, according to Jung, the woods are a mother symbol representative of the dual nature of the mother which includes magic authority, wisdom, spiritual exaltation, instinct, growth and fertility, magic transformation and rebirth, but also darkness, secret, and anything that is "terrifying 
and inescapable like faith" (2010: 139). Thus, in the woods, Hlapić and Gita find more than they had hoped for, for it was Master Scowler who was in fact robbed on his way to the fair (BASB: 104):

For two whole days Master Scowler remained tied to the tree, and as he was quite sure that there was no help for him, he commended his soul to God. He remembered everything he had done in his life, good and evil, and he also remembered Lapitch and longed to see him once more. When a man is tied to a tree for two days without food or drink, he has plenty of time to ponder, and the way he thinks about his apprentice then is quite different from when he is shouting at him in the workshop.

The reunion with Master Scowler who had seen the error of his ways because of his own state of vulnerability is in fact a reunion of a family separated long ago. Like Huck, Alice, Gerda, or Dorothy, Gita and Hlapić returned to society, were reintegrated into their family unit, ${ }^{8}$ and when they grew up (119):

They had four children and three apprentices. And sometimes, on Sunday afternoons, the children and the apprentices would gather round to listen to the story of Hlapić's wonderful adventures. His boots stood in a glass case, where everybody could see them.

Much like Alice's or Wendy's, Hlapić's journey turns him into a storyteller (McGillis 1983: 20; Suchan 1978: 91) who makes the eyes of children "bright and eager with many a strange tale, perhaps even with the dream of Wonderland of long ago" (Carroll 1981: 97). Having become storytellers and original improvisers, such characters do not recall the hardships of their journeys but rather moments of the playfulness and joy of childhood. As Lucy Maud Montgomery wrote, "Only a few, who remain children at heart, can ever find that fair, lost path again, and blessed are they above mortals [...]. The world calls them its singers and poets and artists and storytellers..." (McGillis 1983: 20). In the end, it is no wonder that Ivana BrlićMažuranić, Hlapić and Gita inspire us to vicariously enter and reinvent their story a hundred years later.

\section{Conclusion}

Viola Spolin, the "mother of improvisational theatre" claimed that "when response to experience takes place at this intuitive level, a person functions beyond a constricted intellectual plane, intelligence is freed" (1999: 3). Accordingly, the improvisers of the Golden Age display intelligence in handling themselves and their surroundings, which is located in the body. Hlapićs artistic and theatrical features might be the reason why the novel is gladly interpreted, performed and

${ }_{8}$ Gita is, in fact, Master and Mistress Scowler's long lost daughter. 
adapted. The great literary improvisers of the Golden Age such as Hlapić, Alice, Peter, Pinocchio, Gerda, Dorothy, Tom or Huck built a foundation on which all literature for children is based. They evoked enjoyment and entertainment which became the most important staple of modern childhood and its products. Their quest is grounded in cultural circumstances, as well as psychological truth. More than anything, however, it is grounded in images, those which Jung claimed to "rise to the surface in dreams and in the visions of artists to restore the psychic balance, whether of the individual or of the epoch" (Helson 1974: 74). Those are the images to which Ivana Brlić-Mažuranić aspired, whose solace she sought and which she so generously left behind. Thus, to Hlapić we owe the suspense and beauty of the Croatian children's novel, and to the works of the Golden Age we owe children's literature as we know it today. Much like Twain, Brlić-Mažuranić belongs with "the great restless creators who never strove for one kind of perfection because perhaps they had something better to do" (Wood Krutch, qtd. in Quirk 2012: 48). It is precisely because of the bodily images of playfulness, interaction, sedimentation, sensuality and vulnerability that the improvisers of the Golden Age keep returning to us, in thoughts, on page, stage and screen "as cheerful as a bird, as brave as a knight, as wise as a book and as good as the sun" (BASB: 119).

\section{References}

\section{Primary Sources}

Brlić-Mažuranić, Ivana. 1913. Čudnovate zgode šegrta Hlapića. Zagreb: Hrv. pedagoškoknjiževni zbor.

Brlić Mažuranić, Ivana. 1971. The Brave Adventures of a Shoemaker's Boy. Transl. by Theresa Mravintz and Branko Brusar. London: J M Dent \& Sons Limited.

Carroll, Lewis. 1981. Alice's Adventures in Wonderland and Through the Looking-Glass. New York: Bantam Books.

Twain, Mark. 2005. The Adventures of Tom Sawyer. London: Bounty Books.

\section{Secondary Sources}

Avery, Gillian. 1995. "The beginnings of children's reading to c. 1700." In Children's Literature - An Illustrated History, edited by Peter Hunt, 1-25. Oxford: Oxford University Press.

Avery, Gillian \& Margaret Kinnell. 1995. "Morality and Levity (1780-1820)." In Children's Literature - An Illustrated History, edited by Peter Hunt, 46-76. Oxford: Oxford University Press.

Beckwith, Osmond. 1976. "The Oddness of Oz." Children's Literature 5: 74-91.

Bettella, Patrizia. 2004. "Pinocchio and Children's Literature." Quaderni d'italianistica 25 (1): 3-8. <http://jps.library.utoronto.ca/index.php/qua/article/viewFile/9216/6179> (accessed April 15, 2013).

Billone, Amy Christine. 2004. "The Boy Who Lived: From Carroll's Alice and Barrie's Peter Pan to Rowling's Harry Potter." Children's Literature 32: 178-202. 
Brlić-Mažuranić, Ivana. 1916. “Autobiografija” [Autobiography]. U svijetu bajki Ivane Brlić-Mažuranić. <http://www.usvijetubajki.org/ivana_brlic-mazuranic/autobiografija/ default.aspx $>$ (accessed March 1, 2013).

Carpenter, Humphrey. 1977. Tolkien: A Biography. New York: Ballantine Books.

Goldman, Alan. 2010. "Huckleberry Finn and Moral Motivation." Philosophy and Literature 34 (1): 1-16.

Helson, Ravenna. 1974. "The Psychological Origins of Fantasy in Mid-Victorian England." Children's Literature 3: 66-76.

Hunt, Peter. 1995. "Editor's Preface." In Children's Literature - An Illustrated History, edited by Peter Hunt, ix-xiv. Oxford: Oxford University Press.

Hunt, Peter. 2012. "The Golden Age of Children's Literature." OUPAcademic. <http:// www.youtube.com/watch? $v=$ g-Hmfkve3pQ $>$ (accessed March 15, 2013).

Jackson, Robert. 2002. “The Emergence of Mark Twain's Missouri: Regional Theory and Adventures of Huckleberry Finn." The Southern Literary Journal 35 (1): 47-69.

Johnstone, Keith. 1989. Impro: Improvisation and the Theatre. London: Methuen Drama.

Jung, C.G. 2010. Four Archetypes. Princeton and Oxford: Princeton University Press.

Kinnell, Margaret. 1995. "Publishing for children (1700-80)." In Children's Literature - An Illustrated History, edited by Peter Hunt, 26-45. Oxford: Oxford University Press.

Lamb, Nancy. 2008. The Art and Craft of Storytelling: A Comprehensive Guide to Classic Writing Techniques. Cincinnati: Writer's Digest Books.

Lockford, Lesa \& Ronald J. Pelias. 2004. "Bodily Poeticizing in Theatrical Improvization: A Typology of Performative Knowledge." Theatre Topics 2: 431-443.

Lovrenčić, Sanja. 2006. U potrazi za Ivanom [Searching for Ivana]. Zagreb: Autorska kuća.

Lynch-Brown, Carol \& Carl M. Tomlinson. 2004. Essentials of Children's Literature. Allyn \& Bacon.

Majhut, Berislav. 2005. Pustolov, siroče i dječja družba [An Adventurer, an Orphan and the Children's Band]. Zagreb: FF press.

Martin, Philip. 2002. The Writer's Guide to Fantasy Literature: From Dragon's Lair to Hero's Quest. Kalmbach Publishing Co.

McGillis, Roderick. 1983. "Fantasy as Adventure: Nineteenth Century Children's Fiction." Children's Literature Association Quarterly 8 (3): 18-22.

McMaster, Juliet. 1992. "The Trinity Archetype in The Jungle Books and The Wizard of Oz." Children's Literature 20: 90-110.

Messenger Davies, Máire. 2011. Children, Media and Culture. McGraw Hill: Open University Press.

Mey, Jacob L. 2003. "Literary Pragmatics.” In The Handbook of Discourse Analysis, edited by Deborah Schiffrin, Deborah Tannen \& Heidi E. Hamilton, 787-816. Malden: Blackwell Publishing.

Mihanović-Salopek, Hrvojka. 2001. "Pogovor" [Afterword]. In Čudnovate zgode šegrta Hlapića by Ivana Brlić-Mažuranić, 121-123. Zagreb: Tiskara Znanje.

Moynihan, Ruth B. 1973. "Ideologies in Children's Literature: Some Preliminary Notes." Children's Literature 2: 166-172.

Official website of the City of Slavonski Brod. $<$ http://www.slavonski-brod.hr/en/> (accessed March 28, 2013).

Pinkola Estés, Clarissa. 1995. Women Who Run With the Wolves. New York: Ballantine Books.

Prusak, Bernard G. 2011. "When Words Fail Us: Reexamining the Conscience of Huckleberry Finn." The Journal of Aesthetic Education 45 (4): 1-22. 
"Put, istina i život Ivane Brlić-Mažuranić" [The Way, the Truth, and the Life of Ivana BrlićMažuranić]. U svijetu bajki Ivane Brlić-Mažuranić. <http://www.usvijetubajki.org/ ivana_brlic-mazuranic/autobiografija/default.aspx $>$ (accessed March 1, 2013).

Quirk, Tom. 2012. "The Flawed Greatness of Huckleberry Finn." American Literary Realism 45 (1): 38-48.

Rogers, Jacquelyn. 2008. "Picturing the Child in Nineteenth-Century Literature: The Artist, the Child and the Changing Society." Children and Libraries 3: 41-46.

Rowling, J. K. 2012. "It All Started on Platform 93/4." J.K. Rowling. <http://www.jkrowling. com> (accessed April 1, 2013).

Ryan Madson, Patricia. 2005. Improv Wisdom: Don't Prepare, Just Show Up. New York: Bell Tower.

Sammons, Martha C. 2004. A Guide Through Narnia. Regent College Publishing.

Scott, Carole. 1990. "Limits of Otherworlds: Rules of the Game in Alice's Adventures and the Jungle Books." (Proceedings). Children's Literature Association Quarterly 20-24.

Spolin, Viola. 1999. Improvisation for the Theater. Evanston: Northwestern University Press.

Suchan, James. 1978. “Alice’s Journey from Alien to Artist.” Children 's Literature 7: 78-92.

Stowell, Phyllis. 1983. "We're All Mad Here." Children's Literature Association Quarterly 8 (2): 5-8.

Tunnell, Michael O. \& James S. Jacobs. 2008. Children's Literature, Briefly. Upper Saddle River, NJ: Pearson.

Twain, Mark. 2005. The Adventures of Tom Sawyer. London: Bounty Books.

Weitzman, Erica. 2007. "The World in Pieces: Concepts of Anxiety in H.C. Andersen's 'The Snow Queen." MLN (Comparative Literature Issue) 122 (5): 1105-1123.

Zaunbrecher, Nicholas J. 2011. "The Elements of Improvisation: Structural Tools for Spontaneous Theatre." Theatre Topics 21 (1): 49-60.

\section{Željka Flegar}

Sveučilište u Osijeku, Učiteljski fakultet

Universität Osijek, Fakultät für Lehrerbildung

\section{Veliki književni improvizatori}

U radu se predstavljaju filozofija $i$ načela na kojima počiva umjetnost improvizacije, a koja potiču iz teorije improvizacijskoga kazališta. U istraživanju se heuristički primjenjuje tipologija kazališne improvizacije na književna djela Zlatnoga doba dječje književnosti kako bi se autore i djela Zlatnoga doba pozicioniralo unutar tjelesne i perceptivne poetike te utvrdilo pripadnost hrvatskoga klasika, realističnoga dječjega romana Čudnovate zgode šegrta Hlapića (1913) Ivane Brlić-Mažuranić tom odlučujućem razdoblju dječje književnosti. Zbog činjenice da se umjetnost improvizacije zasniva na pripovijedanju, a književnost, riječima slavnih književnika, stvara kroz slike, cilj je ove analize iznjedriti dokaze kako su Čudnovate zgode šegrta Hlapića, poput ostalih najvažnijih međunarodnih djela Zlatnoga doba, također vrhunski primjer improvizacijskoga procesa, koji se očituje kroz "poetiku tijela” kako ju definiraju Lockford i Pelias (2004). Rezultat ovoga kreativnoga procesa je 
istrajnost, univerzalnost i prilagodljivost književnih djela Zlatnoga doba, a među njima $i$ dječjega romana Čudnovate zgode šegrta Hlapića.

Ključne riječi: arhetip, poetika tijela, Zlatno doba dječje književnosti, kazalište improvizacije, književna pragmatika, realistični roman, Čudnovate zgode šegrta Hlapića

\section{Große literarische Improvisatoren}

Im Beitrag werden die aus der Theorie des Improvisationstheaters stammende Philosophie und die auf ihren Grundsätzen beruhende Improvisationskunst vorgestellt. In typologischer Anwendung der Theaterimprovisation auf literarische Werke aus der kinderliterarischen , Goldenen Zeit', werden die ihr zugerechneten Autoren und Werke innerhalb der leiblichen und perzeptiven Poetik verortet. Darüber hinaus wird die Zugehörigkeit des realistischen Kinderromans und kroatischen Klassikers Čudnovate zgode šegrta Hlapića [Wunderbare Reise des Schusterjungen Clapitsch] (1913) von Ivana Brlić-Mažuranić zu diesem signifikanten Zeitabschnitt in der Kinderliteratur aufgezeigt. Ausgehend von der Tatsache, dass die Improvisationskunst auf dem Erzählen beruht und die Literatur nach Meinung bekannter Schriftsteller durch Bilder geschaffen wird, wird im Beitrag dargelegt, dass der Roman Šegrt Hlapić analog zu den herausragenden internationalen Werken der, Goldenen Zeit' ein Musterbeispiel für Improvisationsprozesse darstellt, wie sie Lockfold und Pelias (2004) in der „Körperpoetik“ definieren. Das Ergebnis dieser kreativen Prozesse manifestiert sich in Fortbestehen, Universalität und Adaptionsmöglichkeiten literarischer Werke aus der , Goldenen Zeit', wie dem Kinderroman Šegrt Hlapić.

Schlüsselwörter: Archetyp, Körperpoetik, ,Goldene Zeit' der Kinderliteratur, Improvisationstheater, literarische Pragmatik, realistischer Roman, Čudnovate zgode šegrta Hlapića 


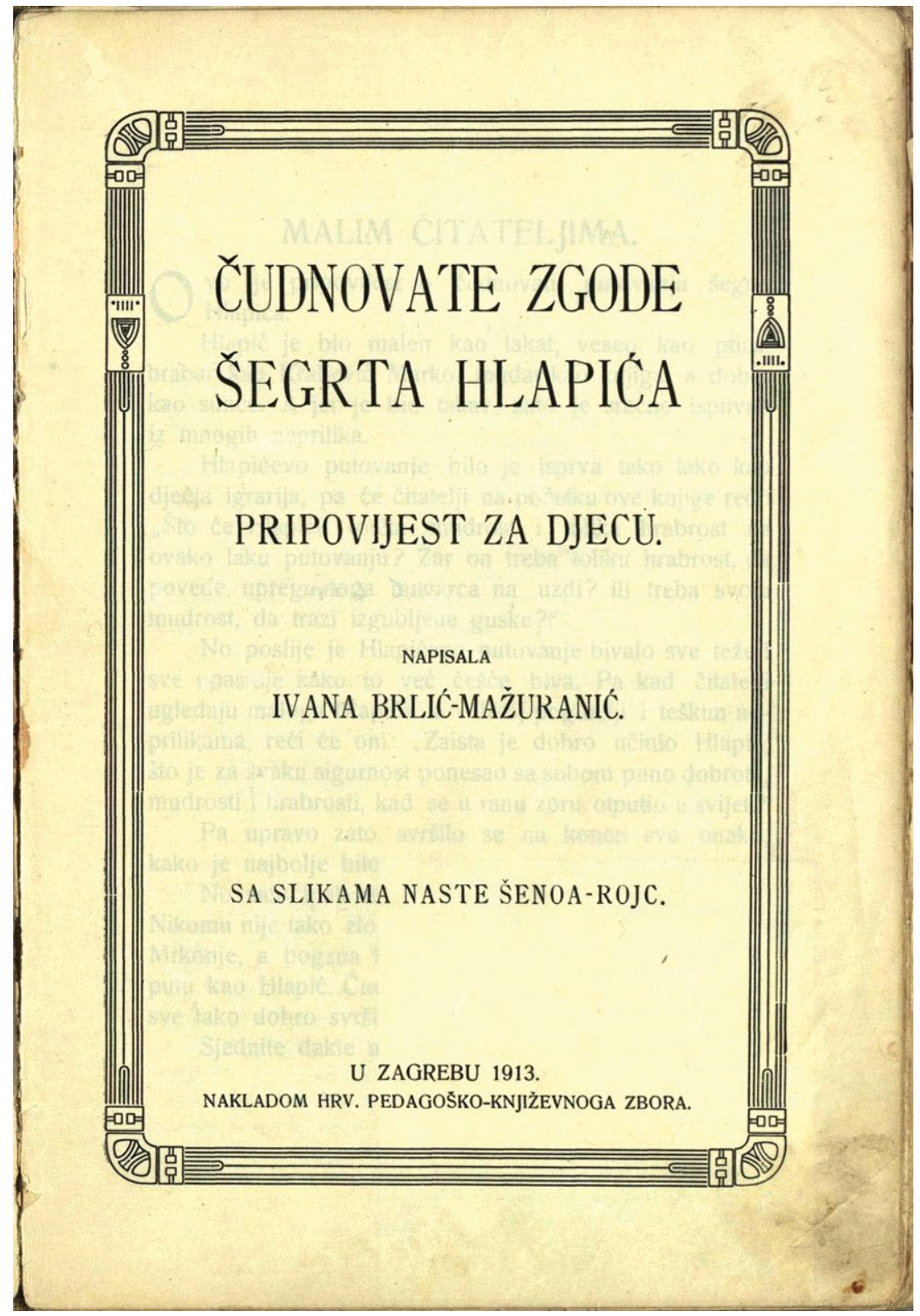

Naslovni list prvoga izdanja Čudnovatih zgoda šegrta Hlapića iz 1913. godine. Digitalno izdanje Knjižnica grada Zagreba u zbirci Digitalizirana zagrebačka baština, dostupno na <http://kgzdzb.arhivpro.hr/>.

Title page of the first edition of The Strange Adventures of Hlapich the Apprentice, 1913. Digital edition by Zagreb City Libraries in the collection

Digitized Zagreb Heritage available at <http://kgzdzb.arhivpro.hr/>. 


\section{Martin Machata}

Sveučilište u Zagrebu, Filozofski fakultet

mmachata@ffzg.hr

\section{O prijevodu i prevođenju Čudnovatih zgoda šegrta Hlapića na slovački}

Izvorni znanstveni članak / original research paper

Primljeno / received 4. 6. 2013.

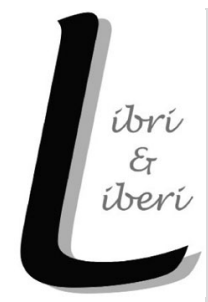

U članku je riječ o slovačkome prijevodu djela Ivane Brlić-Mažuranić Čudnovate zgode šegrta Hlapića (1913), Podivné príhody učňa Chlapčeka, koji je objavljen 1940. godine. Prijevod navedenoga djela razmatra se u kontekstu dvaju 'malih', srodnih slavenskih jezika $i$ dviju 'malih' europskih književnosti. Posebna se pozornost posvećuje funkcionalnosti prijevoda za potrebe današnjega slovačkoga dječjega čitatelja, tj. njegovoj aktualnosti odnosno zastarjelosti, a govori se $i$ o uvjetima $i$ društvenim $i$ političkim okolnostima u kojima je taj najpoznatiji hrvatski dječji roman preveden na slovački jezik. Analiziraju se jezična sredstva prijevoda i izvornika te se na razini leksika i stila nastoji upozoriti na vrline i nedostatke toga prvoga, ali zasad i posljednjega pokušaja da se Šegrt Hlapić učini dostupnim slovačkoj (ne samo dječjoj) čitateljskoj publici.

Ključne riječi: dječja književnost, hrvatski jezik, prijevod, slovački jezik, suvremenost, zastarjelost, Čudnovate zgode šegrta Hlapića

\section{Uvod}

Djelo o kojemu je riječ u ovome radu, prijevod djela Ivane Brlić-Mažuranić Čudnovate zgode šegrta Hlapića (1913) na slovački jezik, jednako je važno kao što je i nepoznato. Prijevod je objavljen u gradu Turčiansky svätý Martin godine 1940. pod naslovom Podivné príhody učňa Chlapčeka, a izdala ga je Matica slovačka kao 59. svezak edicije „Dobré slovo“ [Dobra riječ]. Prijevod ima 166 stranica, tvrd uvez i naslovnicu u boji, a u knjizi se nalazi i nekoliko crno-bijelih ilustracija tipičnih za vrijeme u kojemu je izdana. Autor je prijevoda Koloman 
Kolomi Geraldini, a autor ilustracija František Kudláč. Značenje toga prijevodnoga i izdavačkoga pothvata sastoji se u tome što se njime Slovacima učinilo dostupnim klasično djelo hrvatske književnosti. Zahvaljujući tome mogla se s njim upoznati slovačka čitateljska javnost, prije svega djeca i mladi čitatelji. U suprotnosti je s time današnje nepoznavanje toga prijevoda u Slovačkoj - za proteklih sedamdesetak godina od izdavanja gotovo je potpuno zaboravljen.

U ovome se radu prikazuju okolnosti u kojima je prijevod nastao, kao i njegova recepcija u Slovačkoj. Dalje se u njemu razmatra kvaliteta prijevoda, njegova aktualnost te mogućnost njegova revitaliziranja i ponovnoga izdavanja u današnjim prilikama. Bez pretjerivanja može se reći da je u slovačkoj dječjoj književnosti teško naći djelo toga formata. Vrijednost je Čudnovatih zgoda šegrta Hlapića u njegovoj vremenskoj i kulturnoj univerzalnosti, u spoju elemenata stvarnosti i dječje priče, $u$ gradskim i seoskim značajkama obuhvaćenima u ograničenom vremenu i prostoru. U radu se spominju i drugi prijevodi djela Ivane Brlić-Mažuranić na slovački jezik i njihov položaj među ostalim prijevodima djela hrvatske književnosti na slovački jezik. Hrvatski jezik i kultura imaju mnogo zajedničkoga sa slovačkim jezikom i kulturom, a hrvatska književnost u prijevodu ima u Slovačkoj tradiciju dugu više od sto pedeset godina. U okviru te duge tradicije, koja je zabilježila i uspone i padove, jedno od poglavlja predstavlja i prijevod o kojemu je ovdje riječ.

\section{Razdoblje nastanka prijevoda}

Čitatelju koji nije bliže upoznat s razvojem hrvatsko-slovačkih književnih i općenito kulturnih odnosa zasigurno će pasti na pamet pitanje zašto je prijevod izdan upravo tijekom rata. O tomu piše Ján Jankovič (2002: 385):

Za postojanja Slovačke Republike (od 1939. godine), posebno nakon nastanka Nezavisne Države Hrvatske (1941.), pa sve do prijelomne 1943. godine, slovačkohrvatski su politički, društveni i književni odnosi kulminirali. Ta kulminacija ipak nije bila ,prirodna“: uzlet je nastao pod vrlo jakim vanjskim pritiskom koji je iznudio promjene u shvaćanju obilježja kontinuiteta i zakrio bit diskontinuiteta - prvi put u povijesti vanjske okolnosti bile su službeno tako shvaćene, da su pozitivno utjecale na uzajamne odnose. U toj iznimnoj situaciji slovački-hrvatski i hrvatsko-slovački odnosi poprimili su takve dimenzije, kakve nisu imali nikada prije.

Usporedbe radi, za dvadeset međuratnih godina (1918. - 1938.) u Slovačkoj je objavljeno 17 književnih prijevoda s hrvatskoga jezika, dok su u razdoblju 1939. - 1948. objavljena 34 prijevoda, od toga 26 beletrističkih naslova. U istome je razdoblju u Hrvatskoj obavljeno šest književnih prijevoda sa slovačkoga jezika (usp. Jankovič 2002: 166). U tom se razdoblju pored spomenutih književnih prijevoda pojavljuje i neusporedivo veći broj prijevoda i članaka o hrvatskoj i slovačkoj književnosti koji su objavljeni u periodici i dnevnome tisku, pri čemu posebnu 
pozornost zaslužuje časopis Tatre $i$ Velebit s podnaslovom Hrvatsko-slovačka smotra. Izdaje ga Hrvatsko-slovačko društvo 1942. i 1943. godine dvojezično u Zagrebu, a ukupno su izašla četiri broja.

Paradoksalno je da tako negativan povijesni događaj kao što je Drugi svjetski rat predstavlja ujedno i najpovoljnije razdoblje u povijesti hrvatsko-slovačke književne i općenito kulturne suradnje. Spomenuti nemili povijesni događaji imali su tako igrom slučaja nemalu zaslugu za izdavanje Čudnovatih zgoda šegrta Hlapića na slovačkom jeziku. Tu pretpostavku potvrđuje i činjenica da to djelo na području tadašnje Čehoslovačke nije ostalo nezapaženo ni u vrijeme nastanka. Više o tome piše sama autorica u svojoj „Autobiografiji“ (Brlić-Mažuranić 1994a: 112):

Godine 1914. poslala sam g. Fileušu u Prag (na molbu profesora Hudeca iz Praga) autorizaciju za prijevod Hlapića na češki jezik. Međutim je buknuo rat te ne znam je li do prijevoda došlo.

Kao što je poznato, djelo je na češkom stvarno objavljeno, i to pod naslovom Podivuhodné přihody ševcovského učně, godine 1930. Taj je prijevod vjerojatno poznatiji od slovačkoga, a spominje se i u izdanju Izabranih djela Ivane BrlićMažuranić, u pismu u kojemu autorica romana, potaknuta izdanjem spomenutoga češkoga prijevoda, otkriva okolnosti koje su je inspirirale za pisanje djela (usp., Brlić-Mažuranić 1994b: 114).

Slovačka je prijevodna književnost morala čekati prijevod Čudnovatih zgoda šegrta Hlapića još deset godina nakon češkoga prijevoda, dok se nisu ostvarili uvjeti povoljni za to, pri čemu oni nisu bili, kao što je već navedeno, ni slučajni niti izolirani. U slovačkom se izdanju ne navodi koje se hrvatsko izdanje knjige koristilo pri prijevodu, no zbog vremenske bliskosti najvjerojatnije je da je u pitanju Kuglijevo izdanje iz 1922. godine. To dokazuje npr. i rečenica „'Oha!‘ vikne Hlapić na konje.“, koja u rukopisu i u izdanju iz 1913. postoji, a u Kuglijevu je izostavljena (usp. Majhut 2010: 212). Naime, u slovačkom izdanju ta rečenica također nedostaje. Isto tako vjerojatno je da se autor slovačkoga prijevoda, K. K. Geraldini, uz izvornik služio i češkim prijevodom, koji mu je vjerojatno bio dostupan, pa je mogao imati određeni utjecaj na slovački prijevod.

Poznavajući genealogiju češko-slovačkih kao i slovačko-hrvatskih povijesnodruštvenih i književnih odnosa može se zaključiti da je malo vjerojatno da bi Čudnovate zgode šegrta Hlapića bile prevedene na slovački jezik da politički kontekst nije bio Drugi svjetski rat. Naime, slovačka čitateljska javnost nikada nije imala teškoća s čitanjem prijevoda djela svjetske literature na češkom jeziku pa je zato vrlo vjerojatno da bi se slovački čitatelji, da djelo nije bilo prevedeno upravo u tom razdoblju, zadovoljili češkim prijevodom, a knjiga poslije možda na slovačkom jeziku ne bi uopće izišla. 


\section{Ukratko o prevoditelju}

Koloman K. Geraldini rođen je 24. listopada 1908. u srednjoslovačkome mjestu Terchová nedaleko Žiline, u rodnome mjestu slavnoga slovačkoga nacionalnoga junaka, hajduka Juraja Jánošíka. Bio je pjesnik, književni kritičar i prevoditelj. Njegov otac Venceslav, po zanimanju majstor klesar, podrijetlom iz planinskoga mjesta Cimego (općina Tione, provincija Trenta), smještenoga u području talijanskih Dolomita, pod nepoznatim je okolnostima krajem devetnaestoga stoljeća došao u Slovačku, a drugi je dom našao u Terchovoj. Jankovič (1997) ga navodi u popisu slovačkih prevoditelja pod imenom Karol Geraldini, dok je u kasnije izdanom drugom dijelu pregleda hrvatske književnosti u slovačkoj kulturi (2002) primijetio grešku i zamijenio ime 'Karol' ispravnim imenom 'Koloman K.'. Važan događaj u Geraldinijevoj biografiji predstavlja studijski boravak u Ljubljani (1936.). Jankovič (2002) o njemu piše da se više bavio slovenskom književnošću (pripremio je izdanja antologija poezije Piesne spod Triglavu (1940) i proze Za križom (1942)), no prevodio je također djela iz hrvatske književnosti. Uz prijevod Čudnovatih zgoda šegrta Hlapića dokazano mu se može pripisati samo prijevod hrvatskih pjesama Nenapisano pismo J. Lovrenovića u prvome broju časopisa Pramen̆ za 1936. godinu, na str. 10 i 11, kao i prijevodi pjesama Jakše Ercegovića i Marijana Matijaševića u dnevniku Gardista (godište 4, br. 81 od 10. 4. 1942.). Geraldini nije bio samo prevoditelj, već i pjesnik: izdao je dvije zbirke poezije, $N a$ ceste $k$ démonom [Na putu demonima] 1932. i Rosa v kalichu [Rosa u kaležu] 1936. Bio je član HSLS-a (Slovačka nacionalna stranka Andreja Hlinke), sudjelovao je u ratnim zbivanjima na frontu i kratko je vrijeme 1944. godine bio član predsjedničke straže predsjednika Slovačke Republike Jozefa Tise. U proljeće 1945. Geraldini odlazi sa svojom obitelji u doživotni egzil, bježeći pred sigurnim smaknućem. U Slovačku se nikada više nije vratio. Umire u emigraciji 27. listopada 1994. u gradiću Miramar u Argentini. Nakon pada komunizma, kao važnoj osobi slovačke kulture međuratnoga i ratnoga razdoblja, izlazi mu 1991. u rodnoj Terchovoj izbor djela. Od 1997. godine počiva u Slovačkoj, na Nacionalnom groblju u Martinu na kojemu su pokopani najveći uglednici iz slovačke povijesti.

\section{Prijevod i recepcija djela Ivane Brlić-Mažuranić na slovačkom jeziku}

Na slovački su jezik prevedene i Priče iz davnine (Povesti z pradávna. Turč. sv. Martin, Matica slovenská, 1931.), petnaest godina nakon objavljivanja hrvatskoga izvornika (1916). Taj je prijevod također vrlo važan pothvat slovačke 
prijevodne književnosti. Već i svrstavanje djela u ediciju „Dobré slovo“, koju izdaje Matica slovačka, nagovještava važnost ove knjige budući da u ovoj ediciji također izlaze npr. Lav Nikolajevič Tolstoj, H. G. Wells ili slovački klasik Martin Kukučín. Prijevod je Priča iz davnine Anne Dollinayove-Vračanove izvrstan. Prevoditeljica je knjizi napisala kratak, ali sadržajan pogovor u kojemu govori o izvornosti autoričina stvaralaštva, ljepoti i bogatstvu njezina jezika, jednostavnom i privlačnom stilu (usp. Jankovič 1997: 101-102). ${ }^{1}$

Nešto kasnije, $\mathrm{u}$ istome povijesnome razdoblju kao i prijevod Čudnovatih zgoda šegrta Hlapića, nastao je slovački prijevod romana Jaša Dalmatin (1943), a preveli su ga Andrej Vrbacký i Ivan Minárik.

Jankovič (2002: 220-222) posvećuje Ivani Brlić-Mažuranić zasebno poglavlje: „Diela pre deti a mládež. Chorvátsky Andersen v slovenčine“ [Djela za djecu i mladež. Hrvatski Andersen na slovačkom]. U njemu piše da Čudnovate zgode šegrta Hlapića, kao i Priče iz davnine, u hrvatskoj književnosti imaju izvanredno, štoviše, kultno značenje. Način pripovijedanja Ivane Brlić-Mažuranić čaroban je i privlačan, a slovački prevoditelj Čudnovatih zgoda šegrta Hlapića uspio ga je sačuvati.

Lijep slovački jezik prijevoda pohvalio je i autor recenzije u časopisu Slovák. U tadašnjem su tisku izišla dva prikaza: dok je časopis Slniečko objavio tek malu promidžbenu bilješku (s.n. 1940), recenzija u Slováku, „Knižka chorvátskej spisovatel'ky pre mládež“ čiji je autor prema vlastitoj arhivi A. Vrbacký (26. 10. 1940), opširnija je i otkriva nešto i o vremenu u kojemu je prijevod izdan (usp. Jankovič 2002: 221).

\section{O jeziku slovačkoga prijevoda}

„Bilo mi je glavno nastojanje da u toj pripovijetci postignem do skrajnje granice jednostavnost i bistrinu sloga i jezika kako bi dječji likovi i prizori zaista proizlazili u pravoj dječjoj čistoći i jasnosti“", piše u svojem osobnom iskazu o nastanku djela njegova autorica (Brlić-Mažuranić 1994a: 112). Kvalitetu prijevoda naglasili su spomenuti, dostupni izvori, važan slovački publicist, novinar i najvažniji prevoditelj sa srpskoga i s hrvatskoga jezika od 1930-ih do 1970-ih godina, Andrej Vrbacký, u časopisu Slovák, kao i njegov nasljednik, akademik, književni teoretičar, prevoditelj i publicist Ján Jankovič (2005: 79):

Preveo je i djelo I. Brlić-Mažuranić, klasične autorice hrvatske književnosti za djecu i mladež. Geraldinijevi prijevodi imaju pečat iskusnoga književnika,

Priče iz davnine bile su objavljene i kasnije: 1976. kao Rozprávky z pradávna u prijevodu Zlatka Klátika i 1991. s naslovom Ctiborova hora a iné rozprávky, opet u prijevodu Zlatka Klátika, jednoga od najvažnijih slovačkih prevoditelja dječje književnosti. 
poznavatelja jezikā i urednika.

Jesu li spomenute značajke kao glavne crte umjetničke namjere Ivane BrlićMažuranić u slovačkome prijevodu stvarno sačuvane, pitanje je koje se ovdje razmatra i na koje se pokušava dati odgovor uz pomoć suvremene translatologije.

Istaknuti slovački translatolog Anton Popovič prepoznaje nekoliko tipova pomaka u prijevodu (Popovič 1975, prema Vilikovský 1984: 49):

1) Konstitucijski je pomak neizbježan, a on je posljedica razlika između jezika izvornika i prijevoda. To su npr. razlike u sustavu glagolskih oblika u različitim jezicima.

2) Individualni pomak motiviran je načinom izražavanja ili idiolektom prevoditelja.

3) Tematski pomak nastaje zamjenom realija (naziva za kulturološke posebnosti), kolokacija ili frazema u prijevodu domaćim elementima. U pravilu se označava kao supstitucija.

4) Negativni pomak nastaje kao posljedica nerazumijevanja izvornika. Može biti motiviran nepoznavanjem jezika ili nepoštivanjem pravila ekvivalencije, a očituje se kao netočan prijevod ili stilsko osiromašivanje izraza izvornika.

Analiza koja slijedi proizlazi iz navedenih tipova pomaka u prijevodu pri čemu se pobliže bavi problematikom prevođenja vlastitih imenica, kao i aktualnosti prijevoda na leksičkoj, pravopisnoj, gramatičkoj i sintaktičkoj razini, a uključuje i fenomen međujezične homonimije i prevoditeljske slobode.

\section{Prevođenje vlastitih imenica}

Pristup prevođenju vlastitih imenica specifičan je aspekt umjetničkoga prijevoda kojemu se može pristupiti na razne načine, no trebao bi prije svega biti koncepcijski jednoznačno riješen. Drugim riječima, prevoditelj bi trebao ili dosljedno sačuvati oblik imena likova i mjesta u priči ili ih uskladiti s jezikom na koji se prevodi i kulturom za koju se prevodi, ako za to ima dobar razlog, npr. ako su ta imena ili nazivi nositelji relevantne informacije glede značenja ili estetike. Primjerice u prijevodu slavne slovačke pripovijetke Riđa junica Martina Kukučína (2011) imena i nazivi humorističnoga sadržaja ne preuzimaju se na hrvatski doslovno, nego se prevode tako da zadrže približno jednak učinak kao vlastite imenice u slovačkom izvorniku: Mrhanovo (slov. mrhat' majetkom - rasipati imovinu) - Rasipovo (hrv.), Tramtária (izmišljena nepoznata daleka zemlja) Dalekovce, Eva Štímdopotoka ['Piškimupotok'] - Eva Svemiuvodupalo, itd.

U Čudnovatim zgodama šegrta Hlapića Ivane Brlić-Mažuranić likova nema mnogo pa tako ni njihovih imena, a toponima nema uopće. ${ }^{2}$ Vlastite imenice

2 Vrijedi s iznimkom primjera toponima Viedeň (hrv. Beč) na str. 96 slovačkoga prijevoda: „To nie je pravda“ odvrkla Gita. „Vo Viedni je ešte viacej l'udí, ako tu a predsa majster Mrkoň a čierny človek nie sú vo Viedni.“ (Brlić-Mažuranić 1940) 
hrvatskoga izvornika prevoditelj Geraldini prilagođava jednostavno, oslanjajući se očito što je moguće više na hrvatski tekst: učeň Chlapček, majster Mrkoň, majstrová, Gita, čierny človek, Grga, Marko, Bundáś, Sokol, Marica. Imena likova djeluju u prijevodu, uz te minimalne pomake, posve prirodno. O njima možemo reći sljedeće: Majstor Mrkonja u slovačkom je prijevodu majster Mrkoň; njegovo ime na hrvatskom, osim što asocira na riječ mrk (zlovoljan), također asocira i na riječ mrak (tama), a u slovačkom na knjišku riječ mrk (hrv. sumrak). Prevoditelj je majstorovo ime samo malo promijenio i postigao asocijaciju vrlo blisku izvorniku. To je prijevodno rješenje omogućeno jezičnom bliskosti hrvatskoga i slovačkoga jezika. No kod imena Grga, ostavljanje istoga oblika kao u hrvatskom jeziku nije više sasvim primjereno. Naime, kao prvo, ime Grga u slovačkom jeziku djeluje nepoznato i strano. Za razliku od imena Gita i Marko ne nalazimo ga u slovačkome kalendaru, a kao drugo, ono asocira na slovački glagol grgat' (hrv. podrigivati) i tako nema konotaciju s djelom. U smislu aktualizacije prijevoda može se predložiti da se ime toga lika prilagodi slovačkom jeziku i kulturi, odnosno zamijeni nekim slovačkim imenom, npr. Jerguš, kao što je u češkom prijevodu Čudnovatih zgoda šegrta Hlapića ime Marica prevedeno kao Maruška.

U knjizi ipak nailazimo na nekoliko iznimaka od spomenute tendencije da se imena iz izvornika preuzimaju s minimalnim promjenama ili nepromijenjena. Hrvatsko ime magarca Kokodan na slovački se prevodi kao Uchán̆, a na češki je prevedeno kao Hýkal. Te su prijevodne intervencije u potpunosti opravdane jer bi, da je ostalo nepromijenjeno, ime magarčića u slovačkom prijevodu (kao i u češkom) djelovalo odviše neobično. Sljedeći je primjer ime pastira Miška, koje je promijenjeno kako u slovačkom tako i u češkom prijevodu, kao Ducko, odnosno Vašik. Ta je promjena u slovačkom prijevodu neadekvatna, odnosno njezina je motivacija u najmanju ruku nejasna. Ime Michal je, zajedno s njegovom eufemiziranom, familijarnom varijantom Miško, u slovačkom jeziku vrlo često, a vrlo je zastupljeno i u slovačkoj dječjoj književnosti, npr.: „Ked’ už dorástol aj mladší Miško, i jemu mamka povedala: Syn môj...“(Dašková 1994: 208 - Slovenský národný korpus [Slovački nacionalni korpus]). Štoviše, s gledišta današnjega slovačkoga jezika, ime Miško puno je češće od imena Ducko u Geraldinijevu prijevodu tako da se može pretpostaviti da se prevoditelj za promjenu toga imena odlučio iz nekih subjektivnih razloga. U Slovačkom nacionalnom korpusu spomenuto se ime nalazi isključivo u funkciji prezimena. Iz tih bi se razloga u suvremenome izdanju prijevoda Čudnovatih zgoda šegrta Hlapića na slovački jezik bilo prikladnije vratiti izvornom imenu maloga pastira - Miško. 


\section{Zastarjelost ili aktualnost prijevoda}

Prijevod od izvornika dijeli barijera: jezična, vremenska i kulturna (usp. Vilikovský 1984: 225). Čudnovate zgode šegrta Hlapića djelo je vremenski i kulturno univerzalno tako da autor prijevoda nije morao rješavati pitanje kako premostiti vremensku i kulturnu barijeru između prijevoda i izvornika. Štoviše, njegov je zadatak posrednika između dviju kultura dodatno olakšan zbog bliskosti hrvatske i slovačke kulture. Usprkos tome nije teško složiti se s mišljenjem da „[n]e postoje dva jezika koji bi bili toliko slični da bi ih se moglo smatrati slikom iste stvarnosti. Svjetovi u kojima žive razne zajednice samostalni su svjetovi, nije to tek jedan jedini svijet, opremljen različitim mehanizmima“" (Sapir 1949, prema Vilikovský 1984: 143).

Pri analizi jezika slovačkoga prijevoda Čudnovatih zgoda šegrta Hlapića na polovima 'zastarjelost - aktualnost' potrebno je još uzeti u obzir i arhaičnost hrvatskoga teksta. U suvremenim hrvatskim izdanjima toga djela (npr. Školska knjiga 2004) zastarjeli ili rijetki leksemi, kao i arhaični gramatički oblici, tumače se u bilješkama (npr. na unutarnjoj margini knjige): prenaraziti se - uplašiti se i začuditi; malta - mitnica, najčešće brkljom označen ulaz u grad (...); ozgo i ozdo - odozgo i odozdo; i slično. Ta je metoda posredovanja arhaičnoga teksta dječjoj čitateljskoj publici od dvostruke koristi: prvo, omogućuje očuvanje povijesnoga kolorita teksta i njegova izvornoga umjetničkoga izraza, a drugo, proširuje se rječnik malih čitatelja i upoznaje ih se s pomalo zaboravljenim blagom materinskoga jezika, čime se njeguje jezična kultura. Može se stoga zaključiti da jezična, a u određenom smislu i vremenska te kulturna barijera, ne dijeli u ovom slučaju samo prijevod i izvornik, nego i sto godina star hrvatski tekst od njegovih današnjih hrvatskih dječjih čitatelja.

Možemo se složiti s nazorom prema kojemu ,svako doba traži svoj prijevod i nova čitanja već napisane književnosti“ (Bašić 2005: 67-68). S druge strane, prekomjerna jezična aktualizacija naštetila bi eventualnom suvremenom izdanju knjige Podivné príhody učňa Chlapčeka. Bolje bi bilo kad bi se u njemu primijenilo isto rješenje kao u suvremenim hrvatskim izdanjima - tumačenja arhaičnih i rijetkih leksema, kao i arhaičnih gramatičkih oblika, na marginama ili u bilješkama. U modernom slovačkom prijevodu pojavila bi se na taj način objašnjenja arhaizama i rijetkih leksema iz Geraldinijeva prijevoda, kao npr.: sirka - zápalka, vál'at' dubatá - robit' kotrmelce, načim - treba. ${ }^{3}$

\footnotetext{
3 Istina, u slovačkoj prijevodnoj književnosti i, prije svega, u dječjoj književnosti praksa je takva da se i autori izvornih djela i prevoditelji trude u što manjem broju navoditi razna tumačenja, bilješke na marginama ili ispod teksta. Stoga postoji mišljenje da bi dijete tekst s navedenim nesuvremenim oblicima jezika jednoznačno odbilo. Upotreba arhaičnih riječi u prijevodu trebala bi se zato svesti na mjeru u kojoj bi dječji čitatelji mogli nesmetano pratiti radnju djela, a da uz pomoć objašnjenja nauče i riječi kojima su se nekada koristili njihovi djedovi i bake.
} 
Leksik se od svih jezičnih slojeva mijenja najdinamičnije pa ne iznenađuje što se leksik prijevoda od današnjega standarda umnogome razlikuje. Pri aktualizaciji slovačkoga teksta bilo bi potrebno na marginama ili ispod teksta dati objašnjenja primjerice sljedećih riječi: hrášková princezka, knajp, kvieta dennica, porúhat'sa, litery, načim, izbica, parobok, šop, loptovat'sa, vycifrovaný, poval, dubatá, grap i dr. jer je riječ o leksemima koje današnji mali slovački čitatelji zasigurno ne poznaju.

\section{Pravopis prijevoda}

Čitatelj knjige Podivné prihody učňa Chlapčeka već na prvi pogled postaje svjestan razlike između pravopisa kojim je pisan prijevod i današnjega pravopisa standardnoga slovačkoga jezika. Autor prijevoda piše pravopisnom normom svojega vremena koja se bitno razlikuje od današnjega pravopisa. Riječ je o istom pravopisu kojim je napisana i npr. Slovačka slovnica Josipa Andrića, izdana u Zagrebu $\mathrm{u}$ istom razdoblju u kojemu su prevedene Čudnovate zgode šegrta Hlapića, a u kojoj također nalazimo neke oblike koji bi se prema današnjem pravopisu smatrali pogrešnima, npr. niesly (Andrić 1942: 140), danas niesli.

$\mathrm{U}$ nastavku se navode primjeri staroga pravopisa u slovačkome prijevodu, a u zagradi iza primjera slijedi današnji pravopisni oblik istoga izraza:

a) svinutý ručniček (zvinutý ručniček), sošivat' (zošivat), shovárat' (zhovárat'), dali sa do svady (dali sa do zvady), celkom ináč smýšlal o svojom učňovi (celkom ináč zmýšlal o svojom učňovi), shrnuli sa (zhrnuli sa), sletí (zleti), svierali (zvierali), zpod žlabu (spod žlabu), sišli (zišli), smýšlal (zmýšlal), utrela si slzu s líca (utrela si slzu z líca), sohol (zohol), složil ruky (zložil ruky), sobrali (zobrali), shŕkli sa (zhŕkli sa) itd.

b) strachopúd (strachopud), gazdina (gazdiná), páckal (packal), súsedkino (susedkino), od rozčulenia (od rozčúlenia), čmelák (čmeliak), hromada skála (hromada skália), obtažné (obtiažne), žíhl'ava (žihl'ava), itd.

c) boly pritesné (boli pritesné), bubnovaly bubienky a piskaly pišstalky (bubnovali bubienky a pískali píśtalky), stály (stáli) itd.

Prethodno navedeni primjeri upućuju na to da se pravopisna odstupanja slovačkoga prijevoda romana Ivane Brlić-Mažuranić od današnje pravopisne norme mogu razvrstati u tri kategorije:

a) zamjena grafema $z$ i $s$ : na mjestima gdje se u današnjem pravopisu upotrebljava grafem $z$, nalazi se u tekstu prijevoda grafem $s$, sošivat' (zošivat), i obratno, umjesto grafema $s$ rabi se grafem $z$, zpod žlabu (spod $\check{z l} l a b u)^{4}$

${ }_{4}$ Riječ je o usklađivanju pisanja prefiksa s-/so- i z-/zo- s izgovorom. 
b) razlike u pisanju kratkih i dugih glasova - od rozčulenia (od rozčúlenia), odnosno dvoglasa - čmelák (čmeliak)

c) pisanje ipsilona u preteritu, kao u današnjem češkom pravopisu - boly pritesné (boli pritesné). ${ }^{5}$

\section{Međujezična homonimija u prijevodu}

Prevođenje sa srodnoga jezika prevoditelju, uz brojne prednosti, donosi i jednu poznatu poteškoću, a to je obilje takozvanih lažnih prijatelja prevoditelja (ponekad nazivanih međujezičnim homonimima), tj. leksema koji imaju isti ili vrlo sličan izraz, a različit sadržaj - na slovačkom zradné slová - doslovno 'izdajničke riječi'. Te je pojave bio zasigurno svjestan i autor slovačkoga prijevoda jer se u njegovu tekstu mogu naći tek vrlo rijetki primjeri spomenute vrste neželjenoga utjecaja hrvatskoga izvornika na slovački prijevod. Potrebno je također naglasiti da je djelo prevedeno bez poznavanja današnje teorije umjetničkoga prevođenja u vrijeme kada prevoditelj ne samo da nije imao na raspolaganju današnja napredna pomagala kao što su jezični korpusi, internetski pretraživači, prijevodne memorije i digitalni rječnici, nego se morao snaći čak i bez hrvatsko-slovačkoga rječnika koji je izišao tek u drugoj polovici dvadesetoga stoljeća. U takvim se okolnostima sa spomenutim problemom, koji ponekad ne uspijevaju riješiti ni današnji prevoditelji, Geraldini uspio suočiti uistinu vrlo uspješno. Od nekoliko slučajeva, kada slovački prevoditelj nije uočio da je riječ o lažnim prijateljima prevoditelja, mogu se navesti sljedeća tri primjera:

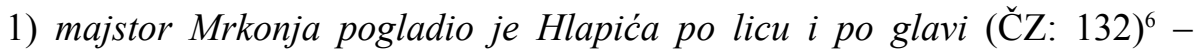
pohladil majster Mrkoň Chlapčeka po líci a po hlave (PP: 141)

2) kao velike zmije (ČZ: 63) - ako dlhé jazyky zmiji (PP: 61)

3) „O, mali moj Hlapiću“ (ČZ: 132) - „, Môj milý Chlapček“ (PP: 140)

U prvom su primjeru lažni prijatelji riječi lice - lice zato što slovačka riječ líce znači obraz, a ekvivalentan prijevod hrvatske riječi lice bila bi riječ tvár. Ispravan prijevod glasio bi tako: pohladil majster Mrkon̆ Chlapčeka po tvári a po hlave.

U drugom su primjeru lažni prijatelji riječi zmija-zmija zato što slovačka riječ zmija znači točno određenu vrstu zmije otrovnice (riđovku) dok je ekvivalentan prijevod hrvatskoga leksema zmija slovački leksem had. Zato bi točan i umjetnički učinkovit slovački prijevod glasio: ako hadie jazyky.

5 Riječ je o ujednačavanju pisanja ovoga oblika u svim rodovima.

6 Primjeri se navode prema kritičkome izdanju Čudnovatih zgoda šegrta Hlapića (Brlić-Mažuranić 2010), a na to se izdanje upućuje kraticom ČZ. Primjeri iz prijevoda na slovački preuzimaju se iz jedinoga slovačkoga izdanja ovoga romana (Brlić-Mažuranić 1940), a na to se izdanje upućuje kraticom PP. 
Treći je primjer nešto drukčije prirode. Prevoditelj tu najvjerojatnije namjerno mijenja značenje tako što riječ mali zamjenjuje riječju milý (na slovačkom: mio, drag) jer mu se to više uklapa u danu situaciju ili mu se čini da je takav način obraćanja djetetu više u duhu jezika primatelja. U svakom slučaju taj se neovisan prevoditeljski pristup u ovom slučaju dobro slaže s kontekstom, a postoji još i mogućnost da je riječ o zatipku što se ipak čini manje vjerojatnim.

\section{Morfološka razina prijevoda}

U slovačkom prijevodu postoje zastarjeli gramatički oblici, kao i u hrvatskom izvorniku, no oni ni u izvorniku ni u prijevodu nisu brojni. U prijevodu su to sljedeći primjeri: očú (PP: 81) (oči), jeho čižiem tu nebolo (PP: 40), (jeho čižmy tu neboli), z cirkusa (PP: 42) (z cirkusu), bolo mu horúce (PP: 61) (bolo mu horúco), ako si po tú ranu prišla (PP: 67) (ako si k tej rane prišla).

U prvom je primjeru (očú) riječ o gramatičkom obliku genitiva množine imenice oko, koji se danas rabi jedino u stilski obilježenim kontekstima, npr. u poeziji.

I u sljedećim dvama primjerima riječ je o oblicima genitiva imenica. Dok je u prvom od njih (jeho čižiem tu nebolo) posrijedi izrazito rijedak, iako ne neispravan, način upotrebe toga padeža, koji je danas u toj funkciji u pravilu zamijenio nominativ, u drugom primjeru ( $z$ cirkusa) danas se u sklonidbi daje prednost gramatičkom obliku z cirkusu što potvrđuju i Kratak rječnik slovačkoga jezika i Pravila slovačkoga pravopisa koji ga navode kao jedini mogući gramatički oblik.

Četvrti primjer (bolo mu horúce) također je s današnjega gledišta neispravan. Riječ horúce danas je pridjev, a u danoj rečenici danas bi na njegovu mjestu bio prilog koji glasi horúco (bolo mu horúco).

$\mathrm{U}$ posljednjem od navedenih primjera riječ je o rekciji. Prijedložna konstrukcija ako si po tú ranu prišla za današnjeg je govornika slovačkog jezika gotovo nerazumljiva i njezino će se značenje shvatiti tek iz konteksta. Naime, ista se prijedložna konstrukcija može i danas funkcionalno upotrijebiti, ali u drugim kontekstima, npr.: prist' po diet'a do školy; prist' po chlieb a mlieko, a ovom bi prijevodu danas bila ekvivalentna druga prijedložna konstrukcija - ako si k tej rane prišla, u kojoj je rekcija u dativu umjesto u akuzativu.

Dalje, Geraldini u cijelom svojem prijevodu dosljedno rabi oblike nominativa (ili akuzativa) imenica koje znače životinje: motýli, netopieri, zajaci (leptiri, šišmiší, zečevi) itd. Danas je češći, a u nekim slučajevima i jedini pravilan oblik: motýle, netopiere, zajace. Primjerice, Krátky slovník slovenského jazyka (2003) navodi kao primarni gramatički oblik nominativa i akuzativa množine oblik zajace, a oblik

\footnotetext{
7 U zagradi se, iza oblika koji rabi prevoditelj, nalazi današnji morfološki oblik istih riječi.
} 
zajaci navodi samo za preneseno, personificirano značenje s kvalifikatorima pren. expr. živ. mn. 'mlad, neiskusan čovjek': neostrielaní zajaci. Oblici netopieri, motýli u tom se rječniku ne nalaze pa bi u suvremenom, aktualiziranom prijevodu prednost trebali imati gramatički oblici: motýle, netopiere, zajace i ostali oblici te vrste pred sekundarnim, odnosno nestandardnim te semantički neobrazloženim gramatičkim oblicima koji se nalaze u slovačkom prijevodu iz 1940. godine.

\section{Sintaktička razina prijevoda}

Struktura rečenice slovačkoga prijevoda u pravilu se ne razlikuje od danas uobičajene sintaktičke strukture slovačkoga jezika. Odstupanje od standarda predstavlja samo rečenica: To nie je žart, lebo ty sa nevad's mojím bratom (PP: 71) (u hrvatskom: „To nije šala, nego se ti ne svađaj s mojim bratom“, ČZ: 72). Izvađena iz konteksta ta rečenica na slovačkom djeluje potpuno neprirodno i nerazumljivo, kao što se može i hrvatski čitatelj uvjeriti na temelju povratnoga prijevoda na hrvatski: „To nije šala, jer ti se ne svađaj s mojim bratom“. Zanimljivo je da ni češki prijevod te rečenice nije uspješan (To není žert, ale nehádej se s mým bratrem (Brlić-Mažuranić 1930: 46) - u hrvatskom prijevodu: „To nije šala, ali ne svađaj se s mojim bratom“.). Ekvivalentni prijevod glasio bi na slovačkom na primjer: To nie je žart, preto sa ty len nevad's mojím bratom. Iza ovih prevoditeljski neuvjerljivih rješenja može stajati nedovoljno poznavanje svih finesa hrvatske sintakse.

\section{Prevoditeljska sloboda}

Prevoditelj oblikuje živo ostvarenje u vlastitu jeziku, književno djelo. ,[...] spisateljska funkcija prevoditelja pretpostavlja stanovitu slobodu nove kontekstualizacije, kao što jest i prevoditeljska funkcija svakoga pisca“" (Maroević 2005: 81). Zadatak prevoditelja književnoga djela, u usporedbi s jezičnom reprodukcijom drugih tekstova, zahtjevniji je u tom pogledu što ,[v]aljana reprodukcija pretpostavlja izražavanje ne samo sadržajne nego i formalne strane teksta s njegovim specifičnim osobinama, emocionalnim opsegom i asocijacijama.“ (Vilikovský 1984: 31)

Geraldini kao književnik i iskusan prevoditelj (iako bez posebnoga prevoditeljskoga obrazovanja) primjenjuje u svojem prijevodu navedene postulate suvremenih translatologa i jezikoslovaca intuitivno i s prirodnim osjećajem za stilske potankosti obaju jezika. Ta se njegova sposobnost dobro vidi na primjeru prevođenja pojedinih naslova poglavlja. Naslovi u kojima je prevoditelj iskoristio svoju prevoditeljsku slobodu navedeni su u sljedećoj tablici. U zadnjem je stupcu tablice metodom tzv. povratnoga prijevoda (back translation) na hrvatski jezik pokazana bit i mjera odstupanja prijevoda od izvornoga naziva tih poglavlja. 


\begin{tabular}{|c|l|l|l|}
\hline $\begin{array}{c}\text { Broj } \\
\text { poglavlja }\end{array}$ & \multicolumn{1}{c|}{ Izvornik } & \multicolumn{1}{c|}{ Slovački prijevod } & \multicolumn{1}{c|}{ Povratni prijevod } \\
\hline 1/III. & Kuća s plavom zvijezdom & Dom s belasou hviezdou & Kuća s modrom zvijezdom \\
\hline 5/IV. & Noć u zapećku & Noc na peci & Noć na peći \\
\hline 6/V. & Bez krova & Bez prístrešia & Bez zaklona \\
\hline 7/III. & Nova pogibelj & Nové nebezpečenstvo & Nova opasnost \\
\hline 7/IV. & Dva opaka čovjeka & Dvaja zlí l'udia & Dvojica zlih ljudi \\
\hline 7/X. & U šikari i mraku & V háji a v tme & U gaju i u mraku \\
\hline 7/XIV. & Kod Markove kuće & Pri Markovej matke & Kod Markove majke \\
\hline
\end{tabular}

Kao što se iz navedenih primjera vidi, rezultat spomenute stanovite slobode nove kontekstualizacije u prijevodu naslova poglavljā izražava se ponekad samo nijansom boje (plava-modra), a ponekad čak zamjenom leksema kuća leksemom majka.

\section{Zaključak}

Slovački je prijevod Čudnovatih zgoda šegrta Hlapića Ivane Brlić-Mažuranić nepravedno zaboravljen u kontekstu prijevodne književnosti s hrvatskoga na slovački jezik, ali i općenito kao dječji roman vrijedan pozornosti mladih slovačkih čitatelja. Iako je prijevod izdan prije više od sedamdeset godina, njegov umjetnički izražaj nije ni nakon toliko vremena izgubio svoju aktualnost. Štoviše, djela te vrste i tih književnoumjetničkih kvaliteta, koja obiluju jasnim porukama i kulturnom univerzalnošću, u slovačkoj dječjoj književnosti nema mnogo. Jezik je prijevoda biran, a prevoditelj vješto i potpuno suvereno barata njegovim bogatstvom. Vrlo rijetko potpada pod neželjeni utjecaj izvornika tj. spretno izbjegava zamke međujezične homonimije. Spretno se koristi mogućnošću prevoditeljske slobode. Prijevod su pohvalila dva najvažnija prevoditelja u povijesti prevođenja hrvatske književnosti na slovački jezik: Andrej Vrbacký i Ján Jankovič. Međutim, zbog velike vremenske udaljenosti između doba u kojemu je prijevod objavljen i današnjice, u prijevodu se ipak primjećuju mnoga odstupanja u odnosu na današnji standardni slovački jezik. Najviše odstupanja od današnjega standarda zabilježeno je, očekivano, na pravopisnoj i leksičkoj razini, a manje na razini morfologije i sintakse.

Iako zasad nema naznaka da bi slovački prijevod Čudnovatih zgoda šegrta Hlapića mogao biti ponovno tiskan, postavlja se pitanje kakav bi on u takvu slučaju trebao biti. Na temelju ovoga rada može se izvesti zaključak da

8 O razlikama u nijansama plave boje i riječima modrý, plavý belasý - plav, modar vidi više u radu Gulešić Machata i Machata (2007: 101-102) 
djelo ne bi trebalo ponovno prevoditi, već bi bilo dobro izdati tek u ponečemu osuvremenjeni Geraldinijev prijevod. U takvu prijevodu, koji bi se temeljio na onomu već postojećemu iz 1940., bilo bi, radi književne revitalizacije toga djela u slovačkom književnom kontekstu, potrebno u prijevodu upotrijebiti pravopisnu normu današnjega slovačkoga jezika te također izvršiti i manje zahvate na razini morfologije i sintakse, kao i u prevođenju vlastitih imenica. Što se tiče arhaizama i rjeđih slovačkih leksema, ne bi ih trebalo zamijeniti suvremenima i češćima, već bi bilo dobro zadržati leksička sredstva Geraldinijeva prijevoda, a na margini, kao u suvremenim hrvatskim izdanjima toga djela, dati njihova objašnjenja. Na taj bi se način sačuvala potrebna 'patina' djela, a dječji bi čitatelji proširili svoj rječnik i ovladali dodatnim izričajima iz slovačke jezične riznice.

Geraldinijev prijevod, nastao zahvaljujući povijesnom trenutku (koji je, iako općenito vrlo tragičan, bio povoljan za prevođenje hrvatske književnosti u Slovačkoj), nepravedno je zaboravljen između ostaloga i zbog povijesnih okolnosti u kojima je prevoditelj morao emigrirati iz Slovačke, a poslijeratna se vlast trudila izbrisati iz kulturnoga pamćenja i prevoditelja i njegova djela. Ovaj rad, analizom različitih razina prevedenoga djela, pokazuje u čemu se sastoji značenje toga prijevoda te nastoji dati doprinos ponovnome pronalaženju njegova mjesta u korpusu slovačke prijevodne književnosti i njegovu ponovnom uključivanju u obzor zanimanja slovačke čitateljske publike.

\section{Popis literature}

\section{Primarna literatura}

Brlić-Mažuranić, Ivana. 1913. Čudnovate zgode šegrta Hlapića: pripovijest za djecu. Zagreb: Hrvatski književno-pedagoški zbor.

Brlić-Mažuranić, Ivana. 1922. Čudnovate zgode šegrta Hlapića: pripovijest za djecu. Zagreb: St. Kugli.

Brlić-Mažuranić, Ivana. 1930. Podivuhodné přihody ševcovského učně: povídka pro děti. [Češki]. Prev. Josef Filouš. Prag: Družstevní práce.

Brlić-Mažuranić, Ivana. 1931. Povesti z pradávna. Prev. Anna Dollinayová-Vračanová. Turč. sv. Martin: Matica slovenská.

Brlić-Mažuranić, Ivana. 1940. Podivné prihody učňa Chlapčeka. Prev. Koloman K. Geraldini. Turčiansky sv. Martin: Matica slovenská.

Brlić-Mažuranić, Ivana. 1943. Jaša Dalmatin. Prev. Andrej Vrbacký i Ivan Minárik. Bratislava - Turč. sv. Martin: Horáček.

Brlić-Mažuranić, Ivana. 2004. Čudnovate zgode šegrta Hlapića. Zagreb: Školska knjiga.

Brlić-Mažuranić, Ivana. 2010. Čudnovate zgode šegrta Hlapića. U Sabrana djela Ivane Brlić-Mažuranić. Romani, ur. Vinko Brešić, 9-155. Slavonski Brod: Ogranak Matice hrvatske.

Kukučín, Martin. 2011. Riđa junica i druge pripovijetke. Prev. Maja Novković, Nikolina Mladić, Samantha Farnwald i Nikolina Komorčec. Zagreb: Matica slovačka Zagreb i FF press. 


\section{Sekundarna literatura}

Andrić, Josip. 2013. Slovačka slovnica. Zagreb: KIKLOS.

Brlić-Mažuranić, Ivana. (1994a). „Autobiografija.“ U Izabrana djela I. Čudnovate zgode šegrta Hlapića. Autobiografski i drugi tekstovi. U svjetlu kritike (I.). Priredio Joža Skok, 101-113. Zagreb: Naša djeca.

Brlić-Mažuranić, Ivana. (1994b). „Pismo Ivane Brlić-Mažuranić o postanku Čudnovatih zgoda šegrta Hlapića." U Izabrana djela I. Čudnovate zgode šegrta Hlapića. Autobiografski i drugi tekstovi. U svjetlu kritike (I.). Priredio Joža Skok, 114-114. Zagreb: Naša djeca.

Bašić, Sonja. 2005. Pisac/prevodilac Antun Šoljan i američka poezija. Skica veće cjeline. U Prevođenje kultura. Zagrebački prevodilački susret 2003, ur. Iva Grgić, 65-71. Zagreb: Društvo hrvatskih književnih prevodilaca.

Dašková, Kveta. 1994. Slovenské rozprávky - Výber z Dobšinského. Bratislava: Q 111. Citat preuzet iz: Slovenský národný korpus. 2004-2013. Jazykovedný ústav L. Štúra Slovenskej akadémie vied <http://korpus.juls.savba.sk/> (pristup 25. lipnja 2013.).

Gulešić Machata, Milvia i Machata, Martin. 2007. „Boje u hrvatskim i slovačkim kolokacijama.“ Riječ: časopis za slavensku filologiju 13 (2): 99-107.

Jankovič, Ján. 1997. Chorvátska literatúra v slovenskej kultúre I. (do roku 1938). Bratislava: Ústav svetovej literatúry SAV.

Jankovič, Ján. 2002. Chorvátska literatúra v slovenskej kultúre II. (1939-1948). Bratislava: Ústav svetovej literatúry SAV.

Jankovič, Ján. 2005. Slovník prekladatel'ov s bibliografiou prekladov z macedónčiny, srbčiny, chorvátčiny a slovinčiny. Bratislava: VEDA.

Majhut, Berislav. 2010. Napomene uz kritičko izdanje. U Sabrana djela Ivane BrlićMažuranić. Romani, ur. Vinko Brešić, 157-189. Slavonski Brod: Ogranak Matice hrvatske.

Maroević, Tonko. 2005. Prevodilac - pjesnikov pomoćnik. Prevoditeljski pogledi i praksa A. Šoljana. U Prevođenje kultura. Zagrebački prevodilački susret 2003, ur. Iva Grgić, 73-85. Zagreb: Društvo hrvatskih književnih prevodilaca.

Slovenský národný korpus. 2004-2013. Jazykovedný ústav L. Štúra Slovenskej akadémie vied $<$ http://korpus.juls.savba.sk/> (pristup 26. lipnja 2013.).

Slovenské slovníky. Jazykovedný ústav L'. Štúra Slovenskej akadémie vied $<$ http://slovniky. korpus.sk/> (pristup 27. lipnja 2013.).

s.n. 1940. „Podivné príhody učňa Chlapčeka.“ Slniečko 14 (3): 53.

Vilikovský, Ján. 1984. Preklad ako tvorba. Bratislava: Slovenský spisovatel'.

[Vrbacký, Andrej]. 26. 10. 1940. „Knižka chorvátskej spisovatel’ky pre mládež.“ Slovák 22 (255):7.

\section{Martin Machata}

University of Zagreb, Faculty of Humanities and Social Sciences

Universität Zagreb, Philosophische Fakultät

\section{The Translation and Translating of Čudnovate zgode šegrta Hlapića into Slovak}

The article deals with the Slovak translation of the children's novel Čudnovate zgode šegrta Hlapića [The Strange Adventures of Hlapich the Apprentice] by Ivana Brlić-Mažuranić 
(1913), titled Podivné príhody učňa Chlapčeka (1940). The translation is considered in the context of two 'small' related languages and two 'small' European literatures. Special attention is paid to the functionality of the translation for the needs of contemporary Slovak child readers, i.e. its actuality or obsolescence, but the paper also focuses on the social and political circumstances in which this Croatian children's classic was translated into the Slovak language. It analyzes the linguistic aspects of the translation in reference to the original, and draws attention to the strengths and weaknesses (at the level of lexis and style) of this first, and so far the only attempt at making Hlapich the Apprentice accessible to a Slovak, not only children's, readership.

Keywords: children's literature, translation, Croatian, Slovak, actuality, obsolescence, Čudnovate zgode šegrta Hlapića

\section{Die slowakische Übersetzung von Čudnovate zgode šegrta Hlapića}

Der Beitrag handelt von der slowakischen Übersetzung des Romans Čudnovate zgode šegrta Hlapića [Wunderbare Reise des Schusterjungen Clapitsch] (1913) von Ivana BrlićMažuranić, die 1940 unter dem Titel Podivné príhody učňa Chlapčeka veröffentlicht wurde. Die Übersetzung wird im Kontext von zwei 'kleinen'verwandten slawischen Sprachen bzw. zwei 'kleinen' europäischen Literaturen besprochen. Das Augenmerk liegt insbesondere auf der Funktionalität der Übersetzung in bezug auf die heutigen slowakischen Kinderleser, d.h. auf Aktualität bzw. Obsoleszenz der Übersetzung. Darüber hinaus werden nicht nur der gesellschaftliche und politische Kontext vorgestellt, innerhalb dessen die slowakische Übersetzung des bekanntesten kroatischen Kinderromans verortet ist, sondern ebenso die verwendeten sprachlichen Mittel der Vorlage und Übersetzung verglichen. Hiervon ausgehend verweist der Beitrag auf die lexikalisch-stilistischen Stärken und Schwächen des bis dato einmaligen Versuches, den Roman Šegrt Hlapić dem slowakischen Kinder- und Erwachsenenlesepublikum zugänglich zu machen.

Schlüsselwörter: Kinderliteratur, Kroatisch, Übersetzung, Slowakisch, Aktualität, Obsoleszenz, Čudnovate zgode šegrta Hlapića 


\section{Vladimira Rezo}

Institut za hrvatski jezik i jezikoslovlje, Zagreb

vrezo@ihjj.hr

\section{Prostor u Čudnovatim zgodama šegrta Hlapića}

Izvorni znanstveni rad / original research paper

Primljeno / received 5. 7. 2013.

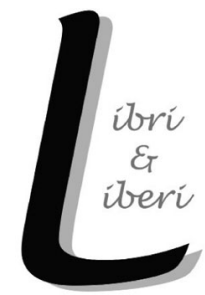

Polazeći od teorijskih postavki suvremenih teoretičara poput Henrija Lefebvrea, Edwarda Soje, Michela Foucaulta, Gastona Bachelarda $i d r$, rad iščitava Čudnovate zgode šegrta Hlapića kao roman ceste (kretanja) $i$ roman prostora (razotkrivanja značenja prostornih uporišta), uz neizbježno isprepletanje dviju perspektiva, uzimajući $u$ obzir autoričino u proslovu višekratno nagoviješteno žanrovsko određenje djela (pripovijest). Protagonist romana napušta sigurno utočište vlastitoga doma prešavši kućni prag, a upravo se ova prostorna minijatura na kojoj se odvija Hlapićev izlazak iz kuće malim recipijentima sugerira kao točka iz koje trebaju stupiti u priču, kao mjesto njihova ulaska u narativni prostor. Našavši se na putu, mali flaner (od trenutka krađe čizmica, tragač za rješenjem problema) osvaja prostor raznim osjetilima, registrirajući mahom pozitivne značajke ruralnoga krajolika, a negativne urbanoga. Hlapićevo se lutanje odvija po nemapiranome prostoru, topografski ispražnjenome, po kojemu su razmještena sporadična spacijalna hvatišta poput štaglja, mosta ili kamenoloma te posebno važna heterotopija sajma i njoj subordinirana heterotopija cirkusa, dva mjesta ,, izvan svakoga mjesta" (Foucault), koja je ipak moguće locirati.

Ključne riječi: prostor, roman ceste, roman prostora, spacijalna hvatišta, heterotopije, Čudnovate zgode šegrta Hlapića, hrvatska dječja književnost

\section{Uvod}

Poznato je da nakon tekstocentričnoga teorijskoga diskursa šezdesetih i sedamdesetih godina prošloga stoljeća poststrukturalistička teorijska praksa u fokus 
stavlja društveni kontekst jezične/književne činjenice. Posljednja tri desetljeća u humanističkim je znanostima uočljiv rastući interes za pitanje prostora. Shodno tomu, i znanost o književnosti u većoj se mjeri fokusirala na pitanje prostora. Pomak od dominacije teorijskoga razmatranja koncepta vremena u korist koncepta prostora započeo je još 1974. Henri Lefebvre knjigom Proizvodnja prostora, u kojoj prostor poima relacijski i naglašava tjelesnu osjetilnost u njegovu doživljaju te nudi njegovu trijadnu podjelu: zamišljen, shvaćen i življen (1991: 356). Politički geograf Edward W. Soja kao uzrok dotadašnjega teorijskoga zapostavljanja prostora navodi dvije iluzije, ,iluziju neprozirnosti“, koja prostor materijalizira i čini ga nepokretnim i nedijalektičnim te ,iluziju prozirnosti“", koja ga svodi na puku predodžbu (1990: 122-126). Od iznimnoga je značenja za temu prostora predavanje Michela Foucaulta o dvjema specifičnim vrstama prostora, nezbiljskim, izokrenutim utopijama i protumjestima, heterotopijama, održano 1967., naslovljeno „O drugim prostorima“. Sva trojica spomenutih teoretičara iznimno su zainteresirana za pitanja društvene proizvodnje prostora.

Razmatrajući kako pojedine zajednice doživljavaju vlastiti prostor, Jacques Le Goff (1983: 805-838) također nudi analizu svedivu na tri temeljna pojma: topografski prostor, kultura prostora i prostor kao umna struktura. Prvi se pojam tiče fizičkoga tla, odnosno njegova prisvajanja i transformiranja od strane zajednice koja na njemu živi, drugi u obzir uzima koncepciju prostora koja se oslanja na prošlost tj. na kozmološko i geografsko znanje o prostoru koje se oblikovalo kroz stoljeća, dok su u trećemu pojmu upisane određene vrijednosti i afektivno vlasništvo koje oblikuje individualno i društveno poimanje prostora. Naše se istraživanje prostornih pojavnica u Čudnovatim zgodama šegrta Hlapića naslanja na ova i slična istraživanja s ciljem propitivanja značenja prostora u djelu, ponajprije njegove prirode kao reprezentacije. Socijalna produkcija prostora zbiva se kao višeslojni i često proturječni društveni proces čija dinamika upućuje na promjenljivost prostora. U našem se slučaju preobrazba ponajprije tiče cirkusa, izmišljenoga, varljivoga mjesta koje to nije.

Kada je riječ o teorijskim djelima koja problematiziraju pojedine segmente prostornosti koje nalazimo u Čudnovatim zgodama šegrta Hlapića, onda ne možemo zaobići kulturalno, antropološko i psihološko 'čitanje' kuće koje kroz analizu različitih tipova literarnih kuća u ruskoj literaturi nudi Joost van Baak (2009). Autora više zanima socijalni, emocionalni i etički koncept kuće nego njezina materijalnost. Kao i Lefebvreu, i van Baaku je kuća i sve što je s njom u vezi (npr. vrt) prostor koji je oblikovao, proizveo čovjek, dakle socijalni konstrukt, artefakt. Van Baakovu teorijsku misao podupiru Bachelardova (2000) promišljanja 
življenoga iskustva pojedinih dijelova kuće: podruma, stubišta, tavana, sobe itd. Poneke od brojnih semantičkih sastavnica raskrižja predočenih u višeslojnoj analizi Jane Garry (2005) prepoznajemo u reprezentaciji onoga križanja putova do kojega je dopješačio Hlapić, a Gitin cirkus postaje razvidniji nakon Bouissacove monografije (2010) te Carmelijevih tekstova $(1987,2001,2003)$ o semiotici cirkusa, dakako, nakon što ga je Foucault već 'iščitao' kroz prizmu heterotopije, a dijelom i kroz prizmu nekih aspekata Bahtinova pojma karnevalesknosti (1967: 162-251).

Prema Francu Morettiju „,[p]rostor nije ‘izvan' priče, nego unutarnja snaga koja je oblikuje iznutra. Ili, drugim riječima, u modernim europskim romanima što se događa uvelike ovisi o tomu gdje se događa“(1998: 70). Nadalje, „,svaki prostor određuje svoju vrstu postupaka, svoj zaplet - svoj žanr“ (84), a „,bez određene vrste prostora određena vrsta priče je jednostavno nemoguća“ (100).

\section{Kuća}

\section{Prag}

Prva je prostorna sastavnica, točka iz koje se malom recipijentu sugerira konzumacija priče koja slijedi, kućni prag. Ova prostorna minijatura mjesto je ulaska recipijenata $\mathrm{u}$ narativni prostor: mali su čitatelji ostavljeni na pragu da kroz diskurs koji im je ponudila Ivana Brlić-Mažuranić participiraju u Hlapićevim pustolovinama. Joost van Baak smatra prag (zajedno s vratima, prozorima, sobom za crtanje i sl.) ,privilegiranim“ prostorom, ,iznutra povezanim s manifestacijom dinamičkih fabularnih motiva na razini sujeta“ [isticanje u izvorniku], odnosno „artikulacijom prostora sukoba“ (2009: 73).

Iako prag obično znači granicu (ovdje između poznatoga i nepoznatoga, domaćega i stranoga) te izazov ili događaj koji je teško prevladati, a njegov prelazak točku s koje više nema povratka, u Hlapićevu je slučaju transgresija imala pozitivne implikacije: na početku romana, prešavši prag, postolarski šegrt odlazi u pustolovinu, napušta poznati svijet, ali se na njegovu kraju vraća i prelazi preko istoga praga na početku novoga, sretnijega života.

\section{Kuća}

Gaston Bachelard kućama (kakve su u Hlapiću uglavnom smještene u ruralnome krajoliku) pripisuje svojstvo vertikalnosti zbog posjedovanja podruma i tavana za razliku od (gradskih) zgrada koje nemaju podruma, pa je njihova visina samo vanjska, nemaju vezu s podzemljem, pa je i život u njima svediv samo na horizontalnost (Bachelard 2000: 39-50). Međutim, Bachelardov princip 
horizontalnosti gradskih zgrada pod znak pitanja stavlja „tri kata visoka“ (ČZ: 24) zgrada u koju je Hlapić odnio mlijeko, i to baš na najviši kat, koji je bio „tako visoko, da je tamo mjesec gledao na prozore“ (25).

Koncept kuće „zamišljene kao vertikalno biće“ (Bachelard 2000: 39) korespondira s modelom „Zatvorene Kuće“ Joosta van Baaka (2009: 85-87)2: vertikalno osmišljene, izrazito hijerarhične, centripetalne kuće, čvrstih granica kojoj je suprotstavljena iz centra izmještena „Otvorena Kuća“, nesamodostatna, bitno labavijih granica.

Zatvorenost domaćega 'gnijezda' povlači pitanje njegove sigurnosti. Pored paradigmatičnoga, iz bajke ${ }^{3}$ naslijeđenoga „sigurnoga staništa“ vlastitoga doma, u Čudnovatim zgodama šegrta Hlapića autorica prezentira i dvije opasne situacije u vlastitoj kući: vatra na Grginu tavanu zamalo je stajala života njegovu bolesnu majku, a u posljednji trenutak spriječena krađa kravice rezultirala bi gubitkom egzistencije dječaka Marka i njegove majke.

\section{Mrkonjina kuća}

Kuća iz koje Hlapić kreće u 'pustolovinu života' patrijarhalna je struktura s gospodarom (Mrkonja) kao nukleusom. Iako u njoj postoji ono što Joost van Baak zove „ideja stabilnoga reda povezana s koncentričnim, ,vlastitim“ domaćim centrom kojemu netko pripada i koji ga identificira“ (2009: 73), za razliku od situacije „u kojoj je takav centar odsutan ili izgubljen ili gdje osobi nedostaje takva prostorno-vrijednosna orijentacija i koja čezne za takvim mjestom“ (ibid.), Hlapić ne spada u junake kojima su događaji zapleta narušili „skladnu“ i „harmoničnu“ (ibid.) početnu situaciju. Iako je kuća jasno strukturirana, konzekvencije koje iz

${ }_{1}$ Primjeri iz romana navode se prema kritičkome izdanju Čudnovatih zgoda šegrta Hlapića (BrlićMažuranić 2010) na koje se upućuje kraticom ČZ.

2 Binarnu je podjelu van Baak osmislio u kontekstu koncepta tradicionalne „svete Rusije“ koja nije počivala samo na moralnoj, ideološkoj i vjerskoj ideji, nego i na „prostornoj stvarnosti“" koju takav koncept podrazumijeva, na temelju kojega su prostori, u skladu s temeljnom binarnom podjelom, podijeljeni na crkvene i svjetovne. Zatvorenoj je kući reforma Petra Velikoga donijela ideološku i kognitivnu inovaciju jer je prihvatila mogućnost jednakosti ruske kulture s drugim kulturama. $\mathrm{Na}$ taj je način Rusija usvojila horizontalan, sekularan i komunikacijski osjetljiviji način približavanja svijetu koji je okružuje i otvorila se prema stranim tehnologijama, znanju i institucijama. Petrovo izmještanje kulture iz Moskve na periferiju mijenja poziciju Rusije, ona priznaje postojanje drugih centara u svijetu, koji su, čak i ako su neprijateljski, ravnopravni, barem u onom osnovnom, antropološkom smislu (2009: 83-87).

3 U brojnim europskim bajkama nalazimo siguran prostor vlastite kuće: Ivica i Marica, Palčić, Zlatokosa i tri medvjeda, Pinokio, Palčica, Mala sirena i dr. Ukoliko je sigurnost doma na bilo koji način kompromitirana, ona se ponovno uspostavlja na kraju bajke: Tri praščića, Vuk i sedam kozlića, Crvenkapica, Snjeguljica i sedam patuljaka itd. U Pričama iz davnine Ivane Brlić-Mažuranić vlastito je stanište uglavnom sigurno mjesto, izuzev u Regoču gdje je zaštićen proplanak izvan sela dok u Šumi Striborovoj mir kućnog ognjišta narušava uljez, snaha. Kako bi problem bio riješen, baka izlazi iz okvira vlastitoga prostora i uspijeva vlastitom nesebičnošću ponovno uspostaviti mir u kući. 
toga proizlaze nikako nisu u Hlapićevu korist. Njemu je Mrkonjina kuća „mjesto dužnosti, obaveza, rutine i neslobode“ (Majhut 2004: 79), u njoj on zauzima Pepeljugino mjesto: „Hlapić je spavao u kuhinji na podu kraj štednjaka. Tamo je imao jednu tvrdu slamnjaču, poderan gunjac i komadić svijeće utaknut u jednom krumpiru, jer svijećnjaka nije imao" (ČZ: 18). Ipak, koliko god uvjeti u kojima obitava bili loši, Hlapić ih je percipirao kao poznate, domaće, vjerojatno i rutinske i samo ga je konflikt s gospodarom prisilio da napusti kuću i otisne se u svijet.

Hlapić je odlaskom na put zamijenio jedan način ,gledanja i doživljavanja prostora“ drugim, odnosno jedan model svijeta drugim: nakon „sjedilačkoga“ pogleda usvojio je „nomadski model“, a po povratku opet „sjedilački“ (usp. van Baak 2009: 67). U kuću iz koje je krenuo na životno putovanje Hlapić se vraća noseći cijelo vrijeme odsutnosti gotovo fizičku inskripciju poznatoga, svoga prostora, „tu strastvenu povezanost svojega tijela koje ne zaboravlja u kući koju nije moguće zaboraviti““ (Bachelard 2000: 37). Međutim, na kraju romana kuća majstora Mrkonje prolazi mijenu: prema tipologiji kuća koju je ponudio Joost van Baak od „kuće bez ljubavi, nesretne kuće“ ona postaje „kuća djetinjstva“ (van Baak 2009: 70-71).

\section{Na cesti}

Bijeg od kuće maloga postolarskoga šegrta artikulirao je prostor ceste kao 'mjesta radnje', ali i motivacije, odnosno ishodišta svih zbivanja ove umekšane inačice 'on the road proze'. Mjesto između startnoga i ciljnoga graničnika, prijelazna zona, cesta, ni u kojem slučaju nije neutralno mjesto. Na njoj se odigrao sudbonosan Hlapićev susret s crnim čovjekom koji će izmijeniti zaplet, a na njoj se dogodio i susret s Gitom što će uvelike utjecati na rasplet događaja - ona je glavno mjesto radnje.

\section{Bez cilja?}

Ruta Čudnovatih zgoda proteže se od domaćega prostora Mrkonjine kuće do javnoga prostora sajma (cirkusa) i natrag. Do trenutka krađe čizmica Hlapić prostor osvaja stihijski, bez plana i pripreme, važnije mu je kretanje nego cilj. Jedino je što Hlapić želi „pobjeći što dalje od majstorove kuće i mjesta na kojemu on živi““ (Matičević 1994: 42). Udaljavajući se od kuće on boravi negdje između, ni tu niti tamo, u pokretu, između dvaju spacijalnih rubnika, onoga poznatoga od kojega bježi i onoga nepoznatoga prema kojemu ide, a put svladava bez ikakvoga otpora (usp. Lihačov 1972: 405). Međutim, pikarska dimenzija Hlapićeva lutanja koju inaugurira Donat (1980: 905), a Frangeš je širi na cijeli roman (1987: 283), što 
preuzimaju Šicel (1989: 343) i Jelčić (2004: 332) održiva je samo do trenutka krađe čizmica. Nakon toga Hlapić je ,išao po svietu tražiti svoje čizmice“ (ČZ: 45), odnosno nije više besciljno lutao. Potraga za čizmicama preustrojila je njegov bijeg od kuće u potragu za crnim čovjekom.

\section{Slijepa karta}

Prostor u kojemu se našao Hlapić zemljopisno je korektan, iako ne i konkretan. U njemu nema ni jednoga toponima (osim što se jednom, kao mjera gradske vreve u usporedbi s fikcionalnim gradom spominje Beč, ČZ: 94), možemo tek naslutiti da njegova ruta vodi kroz kontinentalnu, nizinsku Hrvatsku (vjerojatno Slavoniju). Izostanak geografske faktografije služi za postizanje „dojma egzotičnosti, da bi opisani prostor mogao biti privlačnim“ (Majhut 2005: 292). Majhut ne može ne spomenuti upravo roman Čudnovate zgode šegrta Hlapića kao paradigmatičan primjer izostanka bilo kakvoga toponima. Skokovoj argumentaciji geografske slobode $^{4}$ u svrhu što kreativnijega doživljaja djeteta (1995: 56) dodajemo još jedno objašnjenje istoga autora, koji Brlićkino izbjegavanje „lokalizacijske doslovnosti“ tumači ostavljanjem „sasvim slobodnog prostora čitateljevoj intuiciji“ (55-56), a zanimljivo je i tumačenje Dubravke Zime (2001: 77) koja smještanje dječjega romana u precizno lokaliziran prostor smatra nepotrebnim: umjesto toponimskih i lokalizacijskih oznaka dovoljne su vizualne i iskustvene, najzornije predočene u sceni dolaska u veliki grad, čime se i zemljopis romana svodi na dječju mjeru. Naposljetku ne smijemo zaboraviti de Certeauovu općenitu argumentaciju (2002: 171-174) primjenljivu i u našem slučaju: iza autoričina odbijanja imenovanja naseljenih i nenaseljenih mjesta duž Hlapićeve linije putovanja krije se demonstracija moći. Ako je topografija znanost nadzora (Duncan i Ley 1994: 1), onda nas Ivana Brlić-Mažuranić razvlašćuje kontrolirati Hlapićev hod po karti.

\section{Slika svijeta}

Svaki osjećaj mjesta nužno je vezan za pojedinčevo prostorno iskustvo, razmišljanja o prostoru uvijek su posljedica određene točke gledišta. Zamisli o kozmosu ili susjednim svjetovima inherentne su subjektu jer svaka praksa spacijalne

${ }^{4}$ Iako autorici dopušta izbjegavanje „lokalizacijske doslovnosti“, Skoku slike koje Ivana BrlićMažuranić opisuje ,,ipak pripadaju konkretnom pejzažnom kontekstu i ambijentu“ (1995: 55), a očigledno mu je „da bi manji grad, ishodište Hlapićeve avanture, mogao biti Slavonski Brod, a onaj veći u koji se stiglo nakon sedmodnevna putovanja Osijek! U prvome slučaju identifikacija je potpomognuta samom genezom djela u kojoj je riječ o konkretnome mjestu, a u drugome se radi o uvjerljivoj pretpostavci s obzirom na to da je riječ o urbanom središtu, sajmišnome stjecištu, trgovinsko-zabavnome centru regije i impozantnoj urbanoj cjelini““ (56). Za razliku od njega Crnković misli da je kao veliki grad opisan Zagreb (1974: 53-54), a isto misli i Majhut (2005: 294) argumentirajući to spominjanjem Beča kao prvoga sljedećega većega grada s kojim se uspoređuje fikcionalni veliki grad. 
reprezentacije, bilo da je riječ o geografskom opisu, karti ili čak o prostoru pjesme, podrazumijeva proces uokvirivanja, djelomičan i uvjetovan točno određenim stajalištem. Ono uspostavlja centar i margine, ono vidi svijet kao jedinstven i uređen oko definirane točke (Gregory 1994: 36). Također, s druge strane, mjesto, budući da ni u kom slučaju nije neutralno, također igra ulogu u oblikovanju pojedinca. Ponuđena slika svijeta omjerena je Hlapićevim mjerilima, temelji se na dvočlanoj podjeli na afirmativan prostor prirode i negativan civilizacije. Kroz riječi i misli maloga bjegunca Ivana Brlić-Mažuranić neprestano podvlači crno-bijelu opoziciju prostora grada i sela, registrira uglavnom pozitivne značajke ruralnoga krajolika i negativne urbanoga. Prvi predstavlja, tuanovski rečeno, kao ,prostor topofilije“, dok na ikonografiju grada gleda prilično „topofobično“ (Tuan, 1974). Mahom otvoren, neinstitucionaliziran (građevine su isključivo privatne kuće) prostor relativno bliskoga zavičaja Hlapiću se čini kao prostor očuđenja: lišen normi i poretka iz kakvoga je izašao. Međutim, on je zapravo bitno „pitomiji“ no što se to Hlapiću čini, jedino su crni čovjek i njegov pomoćnik Grga oni koji narušavaju 'prirodan' poredak stvari. Ipak, čak i takav, prostor daje Hlapiću mogućnost slobodnijega djelovanja, on je u prilici pokazati i dokazati svoje sposobnosti.

\section{Proporcije i osjetila}

$\mathrm{U}$ opisu ceste ponuđene su proporcije, omjeri, usporedbe, sukladne Lefebvreovu (1991) relacijskomu poimanju prostora: „Hlapić i Gita išli su po cesti kao dva mrava po toj slamki“ (ČZ: 71). „'Kad sam pošao da tražim čizme, učinila mi se je [ova zemlja] velika i široka kao sedam carevina - a sada, kad se bojim da ću susresti crnoga čovjeka, čini mi se malena i tijesna kao rog!', odvrati Hlapić“" (85). Sam Hlapić verbalizira ideju o ovisnosti procjene udaljenosti i veličine prostora o percepciji - percepcija je podložna promjenama, a zasniva se na prethodnom znanju i iskustvu, ali i trenutačnom dojmu.

Nevelik geografski prostor Čudnovatih zgoda postolarski šegrt (i njegovo društvo) uglavnom svladavaju hodajući, tek se manjim dijelom oslanjajući na prijevozna sredstva. Prilikom jednokratne vožnje na kolima Ivana Brlić-Mažuranić nije Hlapiću promijenila točku gledišta, niti ga je sjedinila sa sredstvom kojim se kreće kroz prostor. Stoga je razumljivo da je Hlapićevo svladavanje udaljenosti manje ovisilo o logistici tj. raspoloživosti kakvoga prometala, a više o suputnicima ili o aktivnostima koje su mu pažnju odvlačile s puta: „Prije no što je zaspao računao je Hlapić u glavi, kako li je daleko od majstora Mrkonje. Onda je izračunao, da nije baš daleko i da bi za jedan dan mogao prevaliti sav put, što ga je prošao za pet dana. To je bilo radi toga, što se s Gitom nije moglo brzo putovati“ (ČZ: 88).

No nisu metri i centimetri jedina mjera, niti hodanje (vožnja) jedini način na koji 
se može 'osvojiti' prostor: značajnu ulogu, prema Lefebvreu, ima tjelesna osjetilnost. Stoga se relacije u njemu mogu uspostaviti i auditivno, a nisu zanemariva ni osjetila mirisa i dodira. U sljedećem je navodu Bundaševo prevaljivanje udaljenosti do Hlapića predočeno Hlapićevim osluškivanjem zvukova koje pas pritom proizvodi: „Čuje on, kako se nešto vuče po travi, kako se šulja i šulja. Sve bliže i bliže čuje, kako nešto tapa i tapa. A onda začuje već sasvim blizu sebe, kako netko jako diše i puše" (ČZ: 29).

Osim tihoga prolaska prostorom, on može biti osvojen poprilično bučno, uz viku i lomljavu (77):

Istom je to pastir izrekao, začuje se veliki štropot sa one ceste koja je išla u brda. Nešto je jurilo i kotrljalo se putem. Čula se je vika i psovka. Hlapić i svi ostali pogledaju po cesti. Sa brda jurila su po cesti kola. Konji su bili poplašeni te su strašnom brzinom letili. Dizali su glave i bacali oko sebe pjenu kao biesni. Kola se kotrljala i nagibala s jedne strane na drugu kao njihalka. Svaki čas se je činilo, da će se stropoštati u jarak.

\section{Spacijalna hvatišta}

U načelno nemapiranom prostoru, topografski ispražnjenom, razmještena su sporadična spacijalna uporišta, odnosno „okrajci ljudskih ambijenata u kojima prenoćuje šegrt Hlapićc" (Majhut 2008: 75). Pored pet prisilnih prenoćišta: štagalj, most, na otvorenom, zapećak, vreće za Gitu i gola zemlja za Hlapića i Bundaša na sajmu, artikulirana su još tri prostorna markera: tavan, kamenolom, i napose, raskrižje. Svima im je dokinuta omeđenost, ta su mjesta sjecišta tokova (Massey 2001: 146-157) kojima su Hlapić, Gita i drugi likovi ispremrežili prostor.

\section{Prisilna prenoćišta}

Improvizirane spavaonice bitno su različitoga ranga. Most i tvrdi sajmišni pod nisu najpoželjnija mjesta na kojima se može provesti noć, ali je skučenu prostoru ispod mosta vrijednost porasla pri pomisli na kišu na otvorenome, a počinak na tlu pored vrtuljka uljepšala je priča za laku noć o kraljevni na zrnu graška. Najviše je na cijeni bila noć provedena na sijenu, vani na zraku. Antropocentrično tumačenje spavanja pod vedrim nebom kozmički poredak preslikava na čovjeku bližu strukturu kuće. U njezinu predstavljanju on ponavlja stvaranje svijeta (Eliade 1958: 379), odnosno strukturu svemira: pod je zemlja, a stupovi su planine koje pridržavaju krov, odnosno nebo (Hugh-Jones 1995: 233-4).

Zapećak u Miškovoj kući, „širok i prostran. U zimi grije, a u ljetu hladi“ (ČZ: 88) predstavljen je samo kao mjesto na kojemu se može prespavati. Autorica je u potpunosti previdjela njegovo značenje u zapadnoj tradiciji kao mjesta koje se povezuje sa ‘ženskim pričama'. Iako su ,trač i usmeno pričanje priča smatrani $[\ldots]$ 
opasnim od strane patrijarhalnog autoriteta i degradirani su na ,zapećak““ (Kincaid 2012: 22), ipak su na tom mjestu od 'sekundarne važnosti' žene bile ovlaštene govoriti.

\section{Kamenolom i tavan}

Postavljen kao naoko usputan cestovni punkt, kamenolom se pokazao značajnim spacijalnim signumom: iz pozicijski uvjetovane funkcije osmatračnice radnika koji su u njemu zaposleni ,,jer oni uviek sjede na cesti i vide svakog putnika“ (ČZ: 38) izrasla je druga, iskustvena komponenta ovoga mjesta, komprimirana u svevremenski 'obrazac' putnika i putovanja: „Onaj, koji ima jake cipele, čvrste šake i pametnu glavu, onomu je dobro na putu“ (ibid.). Kamenolom je, nadalje, mjesto na kojemu je crni čovjek počinio 'salto mortale' ,valjda u noći tamo s one odkopane stijene“ (139). Razrješenjem životne petlje glavnoga negativca priča se može završiti, $\mathrm{i}$ to jedino u sretnom tonu.

Sljedeće je važno prostorno uporište na Hlapićevu putu Grgin tavan. Puno prije no što je Hlapić stigao do njega, autorica nam je dala naslutiti značenje tavana: kada Hlapić razmišlja gdje je crni čovjek mogao skriti čizmice, skalu mogućih skrovišta omeđuje nekim općenitim tavanom kao najviše pozicioniranim mjestom koje njegova glavica može zamisliti i podrumom, najnižom, u zemlju ukopanom pohranom. Isto je semantičko određenje preuzeo konkretan, Grgin tavan, u trenutku Hlapićeva fizičkoga boravka u njemu. Tavan predstavlja prostor za skladištenje, napose ukradenoga blaga koje treba ostati izvan dometa tuđih pogleda. S tim u vezi zanimljivo je spomenuti sličnost ruskih riječi za 'krov' (кров, крыша) i 'blago' (сокровище) te sličnost latinskoga glagola 'tego' (pokriti, skriti) i imenice 'tectum' (koja znači 'kuća', ali i 'krov'). Joost van Baak drži da je u pitanju „koncept kuće lingvistički oblikovan kao zaštitna struktura par exellence“" (2009: 28).

\section{Raskrižje}

Izbor između dviju cesta spominje se još u Starom zavjetu, kada Ezekiel govori o dvama mogućim putovima, prema Jeruzalemu ili Ammonu, između kojih će morati izabrati babilonski kralj (Garry 2005: 334). To je mjesto smaknuća te ukopa samoubojica, od drevne Grčke do Engleske devetnaestoga stoljeća (333, 337), a također i mjesto potpisivanja ugovora s vragom; spomenimo doktora Faustusa te u prvoj polovini 20. stoljeća raširenu urbanu legendu o nekolicini južnjačkih blues glazbenika koji su tako dobro svirali da se govorkalo da su prodali dušu vragu (340). Izbor između dviju cesta dakako ima i metaforičko značenje kao „odabir životnoga puta“ (335) i s tim povezan strah od krivoga odabira (na takvome raskrižju na kojemu, naravno, nema putokaza). Na raskrižjima stoje bogovi-zaštitnici putova 
i putnika, npr. Hermes, koji je ujedno gospodar magične granice dvaju svjetova, običnoga ljudskoga i božanskoga (339), a uz njih se veže i prisutnost magijskih bića: vještica, vukodlaka, vampira, ali i vila (338).

Uz raskrižje se u Čudnovatim zgodama veže samo potonja sastavnica, i to u prošlom vremenu: „Ljudi pripovijedaju da su se na raskršćima u staro doba sastajali vilenjaci, vještice i vukodlaci“ (ČZ: 71). U sadašnjosti je Brlićkino raskrižje ljeti mjesto druženja seoske djece, sociološki značajna pozicija, dok zimi gubi socijalnu komponentu za seosku zajednicu i postaje izletištem i igraonicom sitnih šumskih životinja (ibid.):

Po ljetu na raskršćima sjede pastirići i režu štapove ili tresu bijele i crne dudove. A po zimi, kad je mjesečina i snijeg, igraju se po noći zečevi na raskršću. Sad je bilo ljeto, pa je na jednoj maloj livadi kraj raskršća bilo mnogo malih pastira i pastirica koji su pasli krave, i pekli kukuruze.

Ipak, u skladu s 'mračnom' prirodom ovoga mjesta jedna od cesta vodi u šumu: „Jedna strana išla je dalje po velikoj ravnici, a druga strana išla je u brdo i u šume“ (ibid.), u kojoj se zbilo Mrkonjino orobljavanje, ali, s druge strane, i Grgino otkupljenje te emocijama nabijen susret djece s majstorom Mrkonjom.

\section{Posljednja točka na putu - sajam (cirkus)}

Na samome kraju Hlapićeva i Gitina putovanja pozicionirana su dva dominantna punkta snažne prostorne semantike, heterotopija sajma i njoj subordinirana heterotopija cirkusa, dva „Treća prostora“ (Bhabha 2004: 76-80), mjesta „izvan svakoga mjesta“ (Foucault 2008: 34), koja je ipak moguće locirati.

Heterotopija sajma/cirkusa je heterotopija odstupanja. Njezino se postojanje tiče pitanja hijerarhije i rituala. Pored vanjske hijerarhije, mjesta sajma na „čudesnom praznom prostoru izvan gradskih granica“ (Foucault 2008: 37), na snazi je i unutarnja organizacija sajmišnoga prostora, mjesto cirkusa u njemu, potom pozicioniranje šatora i pojedinih kola. Dakle, naše male lutalice sajam nalaze već pri samome ulasku u grad: „Ali Hlapić i Gita nisu trebali proći svih stotinu ulica, nego samo jednu, jer su odma došli na jednu vrlo veliku pijacu. Na toj pijaci je baš bio sajam" (ČZ: 93). Nasuprot rubnoj poziciji sajma, cirkus je u njemu postavljen u samo središte: „Još malo, i Hlapić i Gita dodjoše na jedan veliki prazan prostor. Nasred toga prostora stajao je veliki okrugli šator, zatvoren i tih kao da spava. Nad vratima bila je dugačka crvena ploča, a na ploči velika slova. To je bio... Gitin cirkus!“(109).

Ritualna se sastavnica tiče ovisnosti ove heterotopije o prolaznoj dimenziji vremena, „,vremena koje se doživljava kao svetkovina“ (Foucault 2008: 37); dvaput godišnje na liminalnome gradskome prostoru uspostavlja se heterotopija koja u 
komprimiranoj formi istodobno uspostavlja i dokida vrijeme i kulturu. Prostor sajma i cirkusa u njemu pojmljen je dinamično, antiesencijalistički, prostor je fluidan u vremenu, prostor je proces (Massey 1999), ni u kojem slučaju reificiran, dapače, otvoren prema novim interakcijama i transformacijama (Lefebvre 1991: 68-168). Cirkus je prostor uz koji se veže iterativnost: neosporno je da Gitin cirkus ima rutinu, on je već barem jednom (kad je bila oteta) gostovao u istome gradu. Ne samo što je cirkus „Treći prostor“, nego još dodatno priziva sjećanja svojih ranijih izvedbi na istome mjestu, potom na drugim mjestima, pred nekom drugom publikom, što znači da se kao heterotopija ne zrcali jednom nego dvaput, njegove su predstave slika slike.

Nadalje, cirkus je i čuvar slika, uspomena i vremena. Postavljanjem šatora, njegovim ,izrastanjem“ na ničijoj (općinskoj) zemlji, taj prostor postaje vidljivim. $\mathrm{Na}$ mjestu nekadašnjega praznoga prostora podiže se zgusnuta, upakirana ikona prolaznosti koja prostor koji zauzima reprezentira brišući ga. To je razlog zašto su ta „ničija mjesta pravi prostori sjećanja“ (Kolstrup 1999: 118).

Putovanje, iznenadno pojavljivanje i iščezavanje dio su cirkuske predstave. Tradicionalno se grad iz kojega je cirkus došao ne spominje, a kad cirkuski djelatnici odlaze kaže se da 'idu dalje'. Dinamika njihova života karakterizirana je „kratkim ostankom na jednome mjestu, stvorenim kako bi se iskusilo stalno kretanje, ,ritam putovanja““(Carmeli 1987: 229). Do trenutka kada je Hlapić nalazi, Gita živi punim životom cirkuskoga izvođača kojemu su posao i stanovanje vezani za isto mjesto. Dolaskom u cirkus Hlapić se zatekao na zaustavnoj točki rute cirkuskih nomada. No, i Hlapić je skitač, lutalica, flaner, makar samo u jednoj etapi života, dok su cirkuski zaposlenici osuđeni na vječito lutanje tijekom cijeloga radnoga vijeka.

Dolaskom cirkusa u grad (a cirkus uvijek putuje noću, samo 'osvane' u gradu) radnici u rekordnom roku postavljaju šator. Omeđivanjem prostora oko šatora pomoću pomičnih ograda, radnici postavljaju granicu prema vanjskome svijetu. No, budući da je ta granica prenosiva, ona je i simbolička (usp. Bouissac 2010: 13). Na tradicionalnim je europskim sajmovima u ,prostoru igre“ granica bila vrlo 'meka': publika i izvođači boravili su u istome prostoru, između njih i publike stajala je zavjesa koja se pomicala kako bi publika vidjela ,izvođače“ (Carmeli 2001: 157-158).

Pored granica, važan segment prostornosti cirkusa u gradu je ,,prodor tuđinske morfologije, sličnije prirodnim oblicima dina i brda, nego kockastima, koji su obilježje urbanih krajolika“ (Bouissac 2010: 13). I Gitin je cirkus smješten u prepoznatljivi „,veliki okrugli šator, zatvoren i tih kao da spava“ (ČZ: 109). Jedna od čestih primjedbi na račun cirkusa u stvarnome životu tiče se upravo okrugloga traga na mjestu nekadašnjega šatora, odnosno ugažene, često i trajno uništene trave 
na mjestima koja su zauzimali šator, vrtuljak i vozila, jedinoga fizičkoga dokaza nedavnoga boravka cirkusa $u$ gradu.

Usporedbom sajma i cirkusa iz romana Ivane Brlić-Mažuranić s Bahtinovim pojmom karnevalesknosti (1967: 162-251) uočavamo da je karnevalsko poimanje svijeta i prakticiranje karnevalskoga života u romanu Čudnovate zgode šegrta Hlapića svedeno na prilično uske granice, zapravo getoizirano. Karnevalesknost prema Bahtinu pretpostavlja disperziran karneval, ,univerzalan“ i „općenarodan“ (1967: 192), premda centralno mjesto i dalje ostaje trg. Tek se Gitina predstava ispred težačke publike može tumačiti kao jednokratan pokušaj reinkarnacije cirkusa bez rampe i granica te nivelacije svih sudionika, odnosno pokušaj ponovne uspostave karnevalizacije izvan uskih granica šatorske konstrukcije u koje je karneval sputan. U liku male artistice sačuvana je rudimentarna ekscentričnost kao jedan od četiriju aspekata karnevalskoga svjetonazora (usp. Bahtin 1967: 187) dok ,slobodan familijarni kontakt među ljudima“ (186) koji nalazimo u romanu može biti rezultat karnevalskoga osjećaja svijeta, ali i dječje perspektive koja se u romanu presudno uzima u obzir. Posljednje dvije karnevalske kategorije o kojima govori Bahtin, „karnevalska mezalijansa“, koja izjednačava sveto i profano, visoko i nisko itd. (188) te ,profanacija“, koja se tiče parodije, nepristojnosti, spuštanja i prizemljenja (ibid.) u potpunosti su ostale izvan vidnoga polja Ivane Brlić-Mažuranić.

\section{Zaključak}

„Prostorni obrat“ je u humanističkim znanostima, pa tako i u znanosti o književnosti, omogućio otvaranje novih problema i sagledavanje nekih starih u novome svjetlu. Dokaz za to je i ovaj roman koji se nameće takvome čitanju ne samo kao „roman ceste“, odnosno kretanja i osvajanja novih zemljopisnih koordinata, nego i ,roman prostora“, mirovanja, istraživanja netom osvojenih prostora $u$ trenutku zaustavljanja na punktovima o kojima je bilo riječi, te, naposljetku, kao roman u kojemu se statična i dinamična perspektiva prožimaju i nadopunjuju.

Iznimno značenje prostorne komponente u Čudnovatim zgodama šegrta Hlapića ilustrirano je pojedinačnim prostornim odrednicama koje nalazimo u romanu. U svakoj od njih upisana je snažna socijalna sastavnica, odnosno iz svih se može iščitati ljudski angažman i proizvedenost. Sukladno proizvedenosti prostora u romanu, i značenje romana u cijelosti može biti iščitano kao stvaralačka intervencija u činjenice biološke i socijalne predestinacije likova, kao aktivno sudjelovanje u proizvodnji njihova života unutar zadanih okvira.

Nadalje, prostor u romanu nosi i etičke implikacije, u službi je karakterizacije 
likova, dinamiziranja radnje i sl. Izvrsnim odabirom prostora u koji je smjestila priču o postolarskom šegrtu Ivana Brlić-Mažuranić osigurala je vjerodostojnost ovom klasiku hrvatske dječje književnosti, a nama mogućnost da u njegovoj analizi pokažemo još jedan sloj nepresušnoga značenja koji roman u sebi krije. Ovaj roman osvjetljava opus Ivane Brlić-Mažuranić svjetlom dinamizma i aktivizma, ni u kojem slučaju prepuštanja. Premda odrasla u tradicionalnome svijetu, Ivana je odškrinula vrata promjenama, emancipaciji, borbi protiv predodređenosti. Roman Čudnovate zgode šegrta Hlapića potvrđuje se kao heterogena baza na koju je moguće primijeniti mnoštvo suvremenih teorija: pluralizam mogućih čitanja potvrđuje ovo djelo kao svevremeno.

\section{Popis literature}

\section{Primarna literatura}

Brlić-Mažuranić, Ivana. 2010. Čudnovate zgode šegrta Hlapića. U Sabrana djela Ivane Brlić-Mažuranić. Romani, ur. Vinko Brešić, 9-155. Slavonski Brod: Ogranak Matice hrvatske.

\section{Sekundarna literatura}

Bachelard, Gaston. 2000. Poetika prostora. Zagreb: Ceres.

Bahtin, Mihail. 1967. „Glava četvrta: žanrovske karakteristike u delima Dostojevskog i sižejno-kompozicijske odlike tih dela." Prev. Milica Nikolić. U Problemi poetike Dostojevskog, 162-251. Beograd: Nolit.

Baba [Bhabha], Homi 2004. Smeštanje kulture, Biblioteka „CirculusGlobus“. Beograd: Beogradski krug.

Bouissac, Paul. 2010. Semiotics at the Circus. Berlin - New York: de Gruyter Mouton.

Carmeli, Yoram S. 1987. „Why Does the 'Jimmy Brown's Circus' Travel?: A Semiotic Approach to the Analysis of Circus Ecology.“ Poetics Today 8 (2): 219-244.

Carmeli, Yoram S. 2001. „Circus Play, Circus Talk, and the Nostalgia for Total Order.“ The Journal of Popular Culture 35 (3): 157-164.

Carmeli, Yoram S. 2003. „Lion on Display: Culture, Nature, and Totality in a Circus Performance." Poetics Today 24 (1): 65-90.

Crnković, Milan. 1974. „Dva šegrta: Ivan i Hlapić.“ Dometi 7 (3): 51-60.

de Certeau, Michel. 2002. „Hodanje gradom.“ U Invencija svakodnevice, 155-176. Zagreb: Naklada MD.

Donat, Branimir. 1980. „Tri strukture, tri duhovna kruga Ivane Brlić-Mažuranić.“ Forum 19 (6): 898-909.

Duncan, James i David Ley. 1994. „Introduction: Representing the Place of Culture“. U Place/Culture/Representation, 1-21. London: Routledge.

Eliade, Mircea. 1958. Patterns in Comparative Religions. London: Sheed and Ward.

Foucault, Michel. 2008. „O drugim prostorima.“ Prev. Mario Kopić. U Operacija: grad: priručnik za život u neoliberalnoj stvarnosti, ur. Leonardo Kovačević i dr., 30-39. Zagreb: Savez za centar za nezavisnu kulturu i mlade - Multimedijalni institut Platforma 9,81 - BLOK - SU Klubtura.

Frangeš, Ivo. 1987. „Ivana Brlić-Mažuranić.“U Povijest hrvatske književnosti, 283. Zagreb: Nakladni zavod Matice hrvatske - Cankarjeva založba. 
Garry, Jane. 2005. „Choice of Roads, Motif N122.0.1, and Crossroads, Various Motifs.“ U Archetypes and Motifs in Folklore and Literature: A Handbook, ur. Jane Garry i Hasan El-Shamy, 333-341. Armonk, New York: M. E. Sharpe.

Gregory, Derek. 1994. Geographical Imaginations. Cambridge, MA: Blackwell.

Hugh-Jones, Stephen. 1995. „Inside-out and Back-to-front: The Androgynous House in Northwest Amazonia." U About the House: Lévi-Strauss and Beyond, ur. Janet Carsten i Stephen Hugh-Jones, 226-252. Cambridge: Cambridge University Press.

Jelčić, Dubravko. 2004. „Ivana Brlić-Mažuranić.“ 2. izd. U Povijest hrvatske književnosti, 332-334. Zagreb: Naklada Pavičić.

Kincaid, Ginger. 2012. „Hawthorne's Gossip Problem: Writing, Gender, and ChimneyCorner Talk." Diesis. Footnotes in Literary Identities 2 (1): 20-29.

Kolstrup, Søren. 1999. „Wings of desire. Space, Memory and Identity.“ 124. <http://pov.imv.au.dk/pdf/pov8.pdf > (pristup 22. veljače 2013.).

Le Goff, Jacques. 1983. „Discorso di chiusura.“ U Popoli e paesi nella cultura altomedievale. 2. Settimane di studio del Centro italiano di studi sull'alto medioevo, 29, 805-838. Spoleto: Centro Italiano di Studi sull'Alto Medioevo.

Lefebvre, Henri. 1991. The Production of Space. Oxford-Cambridge: Blackwell.

Lihačov, Dmitrij Sergejevič. 1972. Poetika stare ruske književnosti, Beograd: Srpska književna zadruga.

Majhut, Berislav. 2004. „Putovanje i ambijent - aspekti pripovijednog prostora u dječjem romanu." U Škola i razvoj: zbornik radova s Međunarodnog znanstveno stručnog skupa Peti Dani Mate Demarina, ur. Ivan Prskalo, 78-87. Petrinja - Zagreb: Visoka učiteljska škola - Hrvatski pedagoško-književni zbor.

Majhut, Berislav. 2005. Pustolov, siroče i dječja družba: hrvatski dječji roman do 1945. Zagreb: FF press.

Majhut, Berislav. 2008. „Recepcija romana Čudnovate zgode šegrta Hlapića Ivane BrlićMažuranić.“ Nova Croatica 2(2): 43-115.

Massey, Doreen. 1999. Power-geometries and the Politics of Space-time. Heidelberg: Hettner lecture.

Massey, Doreen. 2001. Space, Place and Gender. $3^{\text {rd }}$ edition. Minneapolis: University of Minnesota Press.

Matičević, Ivica. 1994. „Zašto su zgode šegrta Hlapića čudnovate.“ U Ivana BrlićMažuranić. Prilozi sa znanstvenostručnog kolokvija 1994. o 120. godišnjici rođenja, ur. Verica Vukelić, 41-46. Slavonski Brod: Grad Slavonski Brod.

Moretti, Franco. 1998. Atlas of the European Novel, 1800-1900. London - New York: Verso.

Skok, Joža. 1995. „Vrijeme, prostor i mjesto zbivanja.“ U Čudnovate zgode šegrta Hlapića i Priče iz davnine Ivane Brlić-Mažuranić, 54-56. Zagreb: Školska knjiga.

Soja, Edward. 1990. Postmodern Geographies. The Reassertion of Space in Critical Social Theory. London-New York: Verso.

Šicel, Miroslav. 1989. „Brlić-Mažuranić, Ivana.“ U Hrvatski biografski leksikon. 2. Bj - C., ur. Aleksandar Stipčević, 342-344. Zagreb: JLZ „Miroslav Krleža“.

Tuan, Yi-Fu. 1974. Topophilia. A study of enviromental perception, attitudes and values. Englewood Cliffs: Prentice-Hall.

van Baak, Joost. 2009. The House in Russian Literature. A Mythopoetic Exploration. New York - Amsterdam: Rodopi.

Zima, Dubravka. 2001. „Dječji romani. Čudnovate zgode šegrta Hlapića (Zagreb, 1913.)،“ U Ivana Brlić-Mažuranić, 62-83. Zagreb: Zavod za znanost o književnosti Filozofskog fakulteta Sveučilišta u Zagrebu. 


\section{Vladimira Rezo}

Institute of Croatian Language and Linguistics, Zagreb

Institut für die kroatische Sprache und Sprachwissenschaft, Zagreb

\section{Notions of space in The Brave Adventures of Hlapich the Apprentice}

Starting from theoretical assumptions of contemporary theoreticians such as Henri Lefebvre, Edward Soja, Michel Foucault, Gaston Bachelard, this paper considers the novel Cudnovate zgode šegrta Hlapića [The Brave Adventures of Hlapich the Apprentice] as a 'road novel' and a representative of the 'space-oriented novel', taking into account the genre's specification as implied in the preface by the author. The main protagonist of the novel leaves the safe haven of the only home he has by crossing the doorstep, and it is precisely this space miniature, in which Hlapich's departure takes place, that is offered to young readers as their point of departure into the story, i.e. their entry point into the narrative space. Finding himself on the road, the little flâneur (from the moment his shoes are stolen, he becomes a problem solver) conquers place with various senses, registering mostly the positive features of the rural landscape and the negative ones of the urban one. Hlapich's wandering occurs in an unmapped space, topographically emptied, across which sporadic spatial points of reference, like a barn, a bridge or a quarry, are deployed, as well as the particularly important heterotopia of the fair, and the one subordinated to it - the heterotopia of the circus - two places that "are outside of all places" (Foucault), even though it may be possible to locate them in reality.

Keywords: 'space-oriented novel', road novel, spatial points of reference, heterotopias, The Strange Adventures of Hlapich the Apprentice, Croatian children's literature

\section{Der Raum im Roman Čudnovate zgode šegrta Hlapića}

Ausgehend von den Ansätzen zeitgenössischer Theoretiker wie jenen von Henri Lefebvre, Edward Soja, Michel Foucault, Gaston Beachelard u. a., wird der Roman Čudnovate zgode šegrta Hlapića [Wunderbare Reise des Schusterjungen Clapitsch] als „, Straßenroman “ bzw. Variante des ,,raumorientierten Romans “ interpretiert. Dabei wird die durch die Verfasserin im Vorwort vorgenommene Gattungsdefinition des Textes als Erzählung berücksichtigt. Der Protagonist verlässt den sicheren Hafen seines Heimes, indem er die Hausschwelle übertritt. Gerade diese räumliche Miniatur, innerhalb der sich Hlapićs Auszug in die Welt vollzieht, dient sowohl als Ausgangspunkt der Geschichte wie auch als Eintrittspunkt für die Rezipienten in den Erzählraum des Romans. Der kleine Flaneur, der Vagabund Hlapić, der nach dem Raub seiner Stiefel zum Problemlöser wird, erobert auf seinem Weg den Raum mit unterschiedlichen Sinnen. Dabei nimmt er die vornehmlich positiven Merkmale ländlicher bzw. negativen Aspekte urbaner Landschaften wahr. Hlapićs Wanderung vollzieht sich durch einen unvermessenen, topographisch entleerten Raum, in dem sporadisch räumliche Bezugspunkte wie die Scheune, die Brücke oder der Steinbruch vorkommen. Darunter ist der Heterotopie des Jahrmarktes, sowie dem ihr untergeordneten Zirkus besonderer Stellenwert beigemessen, denn obgleich sie lokalisierbar sind, handelt es sich um „Orte außerhalb aller Orte " (Foucault).

Schlüsselwörter: Raum, Straßenroman, Raumroman, räumliche Bezugspunkte, Heterotopie, Čudnovate zgode šegrta Hlapića, kroatische Kinderliteratur 


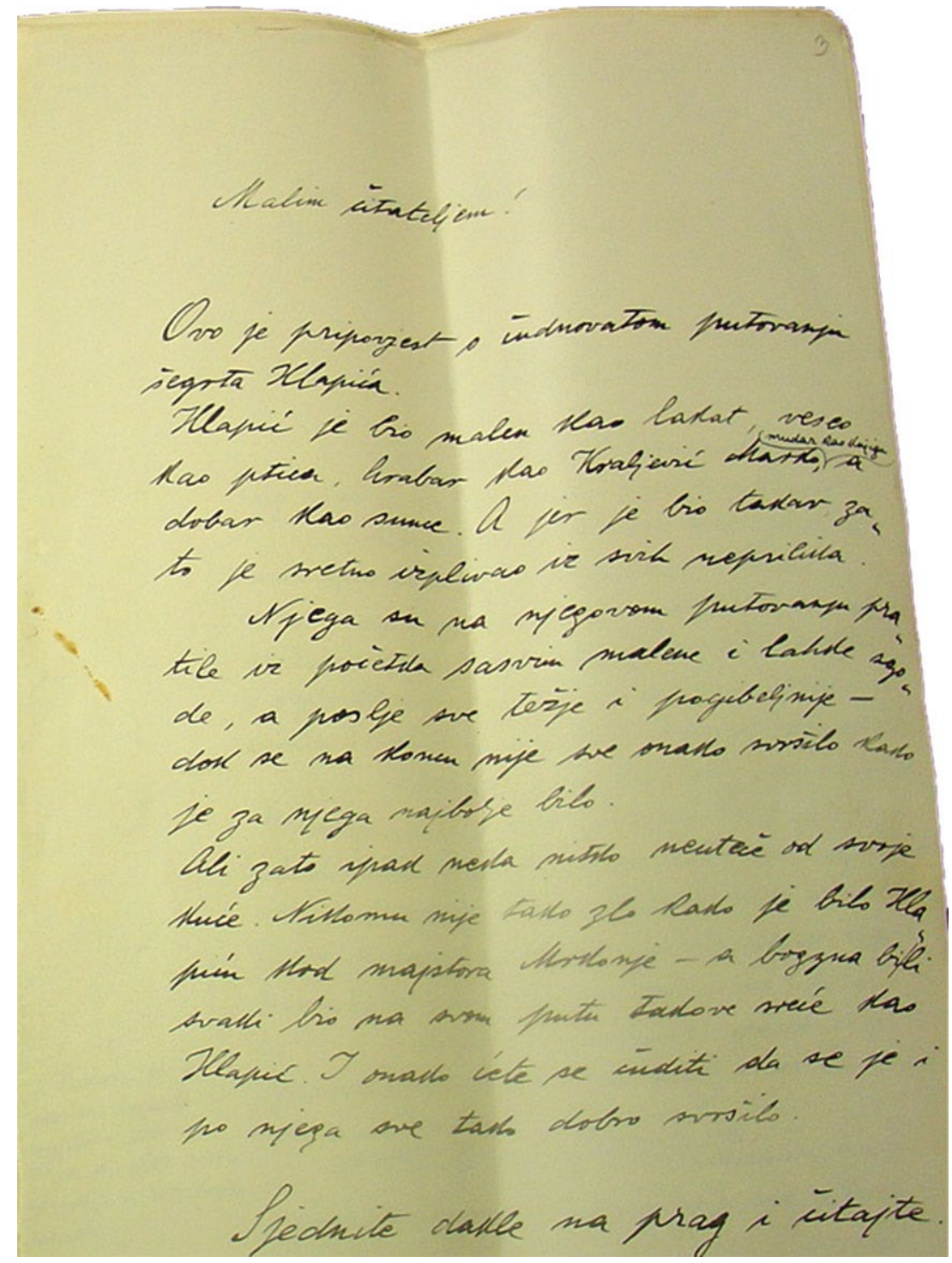

Arhiv obitelji Brlić, kutija inv. br. 82, svežnjić 8 .

Rukopis romana Čudnovate zgode šegrta Hlapića Ivane Brlić-Mažuranić.

Predgovor.

Original manuscript of The Strange Adventures of Hlapich the Apprentice by Ivana Brlić-Mažuranić. Foreword. 


\section{Jelena Vignjević}

Sveučilište u Zagrebu, Učiteljski fakultet

jelena.vignjevic@ufzg.hr

\section{Jezičnostilske osobitosti rukopisa i prvotiska Čudnovatih zgoda šegrta Hlapića u jezičnopovijesnom kontekstu}

Izvorni znanstveni rad / original research paper

Primljeno / received 27. 11. 2013.

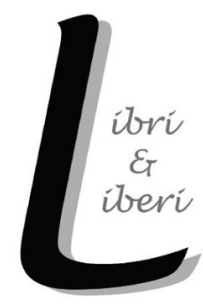

Usporedno čitanje rukopisa romana Čudnovate zgode šegrta Hlapića Ivane Brlić-Mažuranić i prvotiska toga romana pokazuje kako su jezičnim izmjenama načinjenima pri objavljivanju knjige narušene brojne jezičnostilske osobitosti autoričina pisanja. Ovaj rad donosi analizu jezičnostilskih osobitosti rukopisa i prvotiska te upućuje na stanje hrvatske pisane riječi i kulture pisanja na početku dvadesetoga stoljeća. Supostojanje, ali $i$ sukobljavanje književnoga jezika $i$ pravopisnih načela zagrebačke filološke škole $i$ škole hrvatskih vukovaca rezultiralo je osebujnom pisanom praksom toga vremena. Jezičnopolitički diktiran smjer onodobnih promjena hrvatskoga književnoga jezika uočen je i u izmjenama rukopisa koje su načinjene u prvotisku romana Čudnovate zgode šegrta Hlapića.

Keywords: Čudnovate zgode šegrta Hlapića, Ivana Brlić-Mažuranić, rukopis, prvotisak, zagrebačka filološka škola, filološka škola hrvatskih vukovaca

\section{Uvod}

Kritičko izdanje romana Čudnovate zgode šegrta Hlapića, objavljeno 97 godina nakon prvotiska (Brlić-Mažuranić 2010), otkrilo je i osvijetlilo put njegova nastanka i objavljivanja. Taj je put, kad se radi o jezičnim mijenama, dakako dio staze povijesti hrvatskoga književnoga jezika. Putovanje od rukopisa do prvotiska uvelike je izmijenilo jezičnostilske osobitosti romana. Berislav Majhut navodi iznenađujuće velik broj izmjena (2010: 186):

IBM dopušta pet ili šest najnužnijih promjena u cijelom svojemu rukopisu (Priče iz davnine, op. J. V.). Kako se morala osjećati 1913. kada je iz tiska dobila ŠH s više od 1500 intervencija u tekstu?! 
Nameće se pitanje: kako je i zbog čega došlo do tolika mijenjanja rukopisa?

Pogledom na jezičnostilske osobitosti rukopisa i prvotiska romana Čudnovate zgode šegrta Hlapića do izražaja dolaze dvije pojave:

1) nedosljednost ortografije u rukopisu: mlieko - mlijeko, tijesne - pretiesne, liepi-lijepo, uviek-uvijek; čizme - čižme; težko - teško, služkinja-sluškinja; siroma - siromak-siromah...

2) brojne izmjene rukopisnoga teksta u prvotisku: ljenčino $\rightarrow$ lijenštino; sutra $\rightarrow$ sjutra; šibica $\rightarrow$ žigica; papira $\rightarrow$ artije, hartije; van $\rightarrow$ napolje; puše $\rightarrow$ duva; prekrižio se $\rightarrow$ prekrstio se; sretno $\rightarrow$ srećno; štala $\rightarrow$ staja; sparina $\rightarrow$ omara; škaf $\rightarrow$ kabao; postolar ne može biti bez šila i dretve $\rightarrow$ postolar ne može da bude...

Godina 1912., u kojoj autorica stvara roman, već je dva desetljeća odmaknuta od početka službene upotrebe Brozova Hrvatskoga pravopisa (1892). Khuenovim imenovanjem toga pravopisa i Gramatike i stilistike hrvatskoga ili srpskoga književnog jezika Tome Maretića iz 1899. godine službenim priručnicima za hrvatski književni jezik hrvatski vukovci i njihova koncepcija književnoga jezika odnijeli su pobjedu nad ostalim hrvatskim književnojezičnim koncepcijama. Kraj 19. i početak 20. stoljeća obilježeni su stoga prevlašću vukovski koncipiranoga hrvatskoga književnoga jezika u tiskanim medijima. No, rukopisna jezična praksa pokazuje drukčije stanje vidljivo i u rukopisu romana Čudnovate zgode šegrta Hlapića Ivane Brlić-Mažuranić. Autorica u rukopisu nedosljedno provodi fonološki pravopis i grafijska rješenja koja zagovaraju hrvatski vukovci. Također nedosljedno provodi rješenja u pravopisnoj tradiciji zagrebačke filološke škole u čijem je duhu jezično i književno odgojena. Tako piše uviek i uvijek; pretiesne i tijesne; čižme i čizme; težko i teško; siroma, siromah i siromak; služkinja i sluškinja; odma i odmah; lahko i lako, ne će/ne ćemo i neće/nećemo...

Ovaj će rad navedene pojave detaljnije analizirati te će razmotriti jezičnopolitičke okolnosti u kojima nastaju rukopis i prvotisak romana kako bi pridonio razumijevanju jezičnostilskih odlika i izmjena.

\section{Jezičnostilske osobitosti rukopisa i njihove izmjene}

Na ortografskoj razini u rukopisu postoji nedosljednost u poštivanju jednoga pravopisnoga načela. Navode se primjeri s brojem pojavljivanja u zagradama: mlieko/mlieka (14), mlijeko/mlijeka (7); mliekar/mliekaru(4), mljekar(2); služkinja/ služkinji/služkinje (11), sluškinja/sluškinji (4); neimam/neima/neimamo/neimaju (26), nenam/nema/nemamo (12); tiesno/tiesan/tiesni/pretiesne (6), tijesne/tijesna 
(2); liep/liepi/liepa/liepu/liepom/liepo (28), lijep/lijepe/lijepu/lijepo/prelijepo (16); uviek (19), uvijek (12); težko (4), teško/teška/tešku (8), diete (8), dijete (5). Navedeni podaci pokazuju da u rukopisu dominira pisanje principom čitke tvorbe.

Prvotisak nije načinio samo izmjene slovopisa $(i e \rightarrow i j e ; d j \rightarrow d$ ) i proveo fonološko načelo bilježenja glasova na granicama morfema (služkinja $\rightarrow$ sluškinja, junačtvo $\rightarrow$ junaštvo), već je zadirao i u leksičku, i u sintagmatsku, i u sintaktičku razinu autoričina teksta, odnosno jezika. Time je uvelike izmijenjena i semantika teksta i autoričin osobit stil pisanja. Izdvojit ćemo tek neke primjere za to.

Arhaizmi i historizmi mahom su zastupljeni u prvom izdanju (Brlić-Mažuranić 1913), što je zadržano i u drugom, osuvremenjivanom izdanju (Brlić-Mažuranić 1922). Među historizmima vrijedi spomenuti leksem soldat koji je u prvotisku izmijenjen u vojnik, leksem forint (u epizodama s Markom i guskama i s košaračem) izmijenjen je u krune, forinta u srebrni novac i novac (u epizodama s Grgom i Grginom majkom). Arhaizam sizati (leksem je zabilježen u Akademijinu rječniku, sv. XV, i oprimjeren Marulićevim tekstom, no u samoj natuknici stoji Maretićev jezični savjet kako ga je bolje zamjenjivati riječju sezati) izmijenjen je u prvom izdanju leksemom sezati. Leksem sasma mijenjan je u sasvim, put u putovanje. Arhaični veznik $n u$ - riječ koja na početku rečenice povezuje s prethodnim tekstom (Anić 2003), isto što i međutim i ali - sustavno je mijenjan u no iako se značenje tih dvaju veznika ne poklapa. Stariji oblik priloga tuj, uz koji se u Akademijinu rječniku (sv. XVIII) navodi: ,adv. isto što i $t u$ od koga je i postao s naveskom $j$, koji se (vjerojatno radi pojačavanja značenja) dodaje demonstrativnim zamjenicama i adverbima“, izmijenjen je u $t u$.

Regionalno obilježenoga leksika, mahom kajkavizama i agramerizama, u rukopisu je puno i sustavno su zamjenjivani štokavizmima: škaf $\rightarrow$ kabao, premišljavao $\rightarrow$ razmišljao, zamazana $\rightarrow$ prljava, falilo $\rightarrow$ nedostajalo, kanta $\rightarrow$ posuda, šćapio $\rightarrow$ dočekao, štala $\rightarrow$ staja, pol sata $\rightarrow$ pô sata, prekrižio se $\rightarrow$ prekrstio se, fućkati/fićukati $\rightarrow$ zviždati, izgine $\rightarrow$ nesta, otepe $\rightarrow$ gurne...

Mnogi su leksemi hrvatskoga jezika mijenjani srbizmima. Npr. sretno $\rightarrow$ srećno, sparina $\rightarrow$ omara, puhati/puše $\rightarrow$ duvati/duva, van $\rightarrow$ napolje, vrpcu $\rightarrow$ vrvcu, šibica $\rightarrow$ žigica, papir $\rightarrow$ artija, sutra $\rightarrow$ sjutra, ljenčino $\rightarrow$ ljenštino, zdenac $\rightarrow$ bunar, opekao $\rightarrow$ opržio, uvečer $\rightarrow$ uveče...

Prvotisak izmjenjuje mnoge stilski obilježene lekseme i poetizme u stilski neobilježene i time narušava autoričin stil pisanja. Tako je u rukopisu riječ tihano zamijenjena sintagmom posve tiho, čime je u rečenici $A$ onda se izšulja Hlapić tiho, tihano iz radione u dvorište. izmijenjena autoričina suptilna nijansa značenja. Leksem probao u rečenici Kad je sin probao čizme... izmijenjen je u obuo, čime se izgubila značenjska nijansa čina prvoga obuvanja, isprobavanja čizama. 
Autorica se u rukopisu koristi ikavskim sljednikom jata u infinitivu i ženskom rodu glagolskoga pridjeva radnoga glagola s jatom i piše: bijesniti, izgoriti, visila, šutiti, grmiti... U prvome je izdanju to izmijenjeno u: bješnjeti, izgorjeti, visjela, šutjela, grmjeti...

Izmjenom nekih leksema sadržaj se posve udaljuje od onoga što je autorica napisala. Npr. u rečenici Hlapić je udarao svojim čvrstim šakama. riječ udarao zamijenjena je riječju udario, čime se izgubio podatak o dugotrajnoj borbi Hlapića i teleta. Isto se dogodilo i izmjenom riječi nisko u rečenici: Pod mostom je bilo nisko i ružno. u tijesno: Pod mostom je bilo tijesno i ružno. i izmjenom riječi potiho riječju polako u iskazu ...onda potiho digne glavu... Značenje je tim postupcima i te kako izmijenjeno.

U rečenici Jer da nije bilo toga oblaka, bogzna ne bi li ih crni čovjek one noći sve bio zatekao. riječ zatekao (iznenadio, našao) u drugom je izdanju izmijenjena u zatukao, čime se značenje uvelike izmijenilo.

Na sintagmatskoj razini mijenjani su mnogi autoričini jezični i stilski postupci. Autorica se u rukopisu koristi stilski obilježenim slavenskim genitivom koji je u prvotisku mijenjan u stilski neobilježeni akuzativ. Npr. ... uzme Hlapić konca $\rightarrow$... uzme Hlapić konac; ...dajte mu više juhe i mekšega kruha $\rightarrow$ dajte mu više juhe $i$ mekši kruh...; ...tim su više trpali u Hlapićevu torbu pečenke, kruha i gibanice... $\rightarrow$...tim su više trpali u Hlapićevu torbu pečenku, kruh i gibanicu...

Dijalektna sintagma imati koga rado mijenjana je u voljeti koga; išao je kroz ulicu $\rightarrow$ išao je ulicom...

Mijenjano je i kajkavsko narječno obilježje upotrebe nominativa na mjestu vokativa: To je lijepo, dragi moj Bundaš! $\rightarrow$ To je lijepo, dragi moj Bundašu! Ili Ti si, nevaljanac, to skrivio! $\rightarrow$ Ti si, nevaljalče, to skrivio! $\rightarrow$ Ti si, nevaljanče, to skrivio!

Puni perfekt u povratnim glagolima zamjenjivan je krnjim: On se je dosjetio... $\rightarrow$ On se dosjetio...; Ipak se je Gita sve više sviđala Hlapiću ... $\rightarrow$ Ipak se Gita sve više sviđala Hlapiću ...; Gita se je na to razsrdila ... $\rightarrow$ Gita se na to rasrdila ...

Izmjene nekih sintagmi autoričin su izričaj primaknule srpskomu književnomu jeziku, npr. što god je šegrt kadar zamisliti $\rightarrow$ što god je šegrt kadar da zamisli; postolar ne može biti bez šila i dretve $\rightarrow$ postolar ne može da bude...; Je li putnicima teško $\rightarrow$ Da li je putnicima teško...

Od sintaktičkih elemenata najviše su mijenjani rečenični veznici i modifikatori značenja. Tako je ali mijenjano u no, pak u $p a$.

Izmijenjene su i stilske osobitosti djela. Brojnim je izmjenama dokinuta sinonimija: $p a$ - pak sustavnim mijenjanjem veznika $p a k$ u $p a ; ~ s t a p-k o l a c$ sustavnim mijenjanjem štapa u kolac; vojnik - soldat izmjenom riječi soldat u vojnik. 
Dokinuta je stilistička upotreba glagolskih oblika za izricanje prošlosti. Aorist je, kao stilski obilježen, zamjenjivan stilski neobilježenim perfektom: Dakako da su se sada svi još više smijali i tako svrši predstava. $\rightarrow$ Dakako da su se sada svi još više smijali i tako je svršila predstava.

Rukopis sadrži stare padežne oblike za dativ množine (malim čitateljem) i lokativ množine ( $p o$ ledji/po ledjih, na malih kolih) uz supostojanje novih padežnih oblika (na/u/pred/sa kolima). Stari su oblici u prvotisku zamijenjeni novim padežnim oblicima (malim čitateljima, po leđima, na malim kolima). Rukopis Ivane Brlić-Mažuranić svjedoči da je stara hrvatska sklonidba, potvrđena u Kašićevoj gramatici 1604. i u Babukićevoj 1836. i bilježena od prvih pisanih spomenika pa do vukovaca, u drugom desetljeću dvadesetoga stoljeća još bila živa u pisanome jeziku, ali vrlo labava, uz pretežuću novu sklonidbu.

Za razumijevanje jezičnostilskih osobitosti rukopisa te razloga i smjera njihovih izmjena u prvotisku potrebno je uroniti u jezičnopovijesne okolnosti njihova nastanka.

\section{Jezičnopolitičko stanje s kraja devetnaestoga i u prvim desetljećima dvadesetoga stoljeća}

$\mathrm{S}$ velikim vremenskim odmakom pri gledanju unatrag skloni smo pojednostavljivanju slike. Tako zaključujemo da se hrvatska pisana riječ mijenjala u skladu s ortografijskim rješenjima koja su iznijeli ilirci, potom onima koja su ostvarili pripadnici zagrebačke škole, pa onima hrvatskih vukovaca. I učini nam se tako da se npr. jat od 30-ih godina 19. stoljeća bilježi kao 'rogato e', potom se desetak godina piše kao ie, i u dugim i u kratkim slogovima, kako je 1858. pisan i Riečnik ilirsko-talianski D. A. Parčića (usp. Marotti 2010: 128), od 50-ih godina istoga stoljeća da se u dugim slogovima bilježi kao ie, a u kratkima kao je, a od 1892. da se bilježi kao ije u dugima ili je u kratkim slogovima. No, uvid u autentične tekstove iz toga vremena pokazuje nešto sasvim drugo. Dvadeset godina nakon Brozova Hrvatskoga pravopisa Ivana Brlić-Mažuranić dugi jat upisuje kao ie i kao ije. A. G. Matoš (prema Galić 1997) u pismu Tomi Didoliću iz 1899. piše: „Moje su materijalne prilike, velecijenjeni gospodine, tako rdjave...“, iste godine Anti Tresiću Pavičiću piše: „Ne mienjajte ništa jer sam pročitao Im-u (Impromptu, op. J. V.) i ispravio pogrješke“. Franjo Iveković gotovo deset godina nakon pravopisnom normom propisanoga $d$ piše gragja. Promjene se sporo prihvaćaju, navike traju, kao i jezikoslovci tako su i pisci i tiskovine priklonjeni zagrebačkoj filološkoj školi ili pak hrvatskim vukovcima. 
Novi pravopis Ivana Broza u onodobnoj se javnosti, zbog mladogramatičarske utemeljenosti i prihvaćanja novoštokavske fonološke strukture hrvatskoga jezika, poimao kao izraz mađaronske političke i jezično-političke misli. Nailazio je stoga na protivljenje velikoga dijela hrvatske književnosti i javnosti, svih protivnika mađaronstva i unionizma. Toj je javnosti zasigurno pripadala i Ivana BrlićMažuranić, od biskupa Josipa Jurja Strossmayera odlikovana zlatnom medaljom za protumađaronska nastojanja. ${ }^{1}$ Dalibor Brozović tu situaciju pojašnjava ovako (Brozović 2008: 109):

Kako se Brozov pravopis gotovo posve poklapao s Karadžićevim - što je normalna posljedica činjenice da oba odgovaraju novoštokavskoj fonološkoj strukturi maretićevci su ga dakako objeručke prihvatili.

Broz Hrvatski pravopis izrađuje na fonološkom načelu. Svjestan stanja u hrvatskoj jezičnoj praksi i stanja u hrvatskom jezikoslovlju predmnijevao je da će tako zasnovan pravopis naići na kritiku i oporbu pa u predgovoru poziva zagovornike korijenskoga, tvorbenoga ili pravopisa čitke tvorbe da izrade pravopis u kojemu će to sustavno provesti (Broz 1892: IV):

Istina, naći će se ljudi, koji će se dizati i na ovo pisanje i opirati mu se, ali to njihovo opiranje bit će kod mlađega naraštaja hrvatskoga zaludno. Nije dovoljno samo rušiti, nego treba i graditi. Tko se prihvati da razgrađuje pravila za ovo pisanje, nek se prihvati i drugoga posla: nek izradi zakone za dojakošnje pisanje, koji će biti barem toliko određeni, prosti, jasni i dosljedni, koliko su u ovoj knjizi, a $\mathrm{k}$ tomu neka postavi pouzdana pravila, kako će moći svatko valjano hrvatski čitati one riječi, koje će se drukčije pisati nego što se izgovaraju.

Ali ja ne vjerujem, da će se naći tko bi napregao svoje sile, da svede u pouzdana pravila pravopis, kojim pišu u nas protivnici fonetičkoga pisanja $[\ldots]$

Pravopis je naišao na brojne kritičare, među inima i Vatroslava Jagića, koji je bio protiv odveć dosljednoga fonološkoga pravopisa (usp. Pranjković 2006: 162).

Da je još dugo po objavljivanju Brozova Hrvatskoga pravopisa potrajalo stanje pravopisnoga nereda, svjedoči i činjenica da u Rječniku hrvatskoga jezika Franje Ivekovića i Ivana Broza objavljenom 1901. nema slova $d$. Taj se palatalni suglasnik bilježi kao gj (tugje). Na tu se činjenicu i na pravopisno stanje osvrće Franjo Iveković s jakom dozom nezadovoljstva u predgovoru tomu Rječniku datiranu 30. lipnja 1900 (1901: v):

Za Vukovo ந pišemo složeno slovo gj, koje je istorijsko jer su stari naši pisali gy ili upravo gj, i koje najbolje odgovara sistemi našega sadašnjeg pravopisa. Po ovoj sistemi valja gledati, da naš svaki glas, kojega nijesu Latini govorili, ima svoj osobiti

U knjizi Slavonski tekst tekst hrvatske književnosti (Sablić Tomić i Rem 2003: 473) navodi se: „Aktivno je pomagala suprugu u borbi protiv Khuen-Héderváryjeva režima, pa je za svoj domoljubni rad dobila od biskupa J. J. Strossmayera zlatni medaljon.“ Taj podatak navodi i Leksikon hrvatske književnosti (Bogišić i sur. 1998: 35). 
znak, prosto slovo, ali da se ne dira u sama Latinska slova; ako se pak ne bi moglo prosto slovo za koji god naš glas načiniti bez diranja u Latinsko slovo, neka se radije načini složeno slovo. ... Nasuprot toj sistemi griješi se u načinjenom slovu đ, jer se dira u samo latinsko slovo d; ali je još gore što se za isti glas pored prostoga slova d dopušta pače zapovijeda kod imena vlastitih još i složeno slovo gj, te treba pisati istu riječ kad znači mjesto (u Hrvatskoj): Gjurgjic, a kad znači cvijet: đurđic! Dakle za jedan isti glas dva različita znaka!

Ta činjenica da u pisanoj praksi supostoje i $d$ i gj i $d j$, dakle da se piše po starim slovopisnim navikama u duhu zagrebačke filološke škole, ali i po novom Brozovu pravopisu, pojašnjava razloge neujednačenosti rukopisa Ivane Brlić-Mažuranić u pisanju $d j$ i $d$. Samo u trima riječima autorica u rukopisu bilježi $d$ : među, pođoše, sađe. U svima ostalima ovaj fonem bilježi kao dj: ledjih, ledji, izadje, takodjer, dodje, pridodje, rodjak, medjutim, unidje, dodju, podje, podju, svidjao, iznenadjenje. Nedosljednost je očita u bilježenju oblika glagola poći: podju, pođoše. Takva jezična praksa kolebanja i nesigurnosti u pisanju dvoslova ili jednoslova za glas đ, odnosno kolebanje između dvaju slovopisnih sustava - onoga zagrebačkoga i onoga daničićevskoga ili vukovskoga, prisutna je u hrvatskoj pisanoj praksi prvih desetljeća dvadesetoga stoljeća. U rukopisu Ivane Brlić-Mažuranić, dakle, nije to autoričina nedosljednost, već onodobno stanje raznolikoga pisanja.

Hrvatski su vukovci zagovarali stilizaciju hrvatskoga književnoga jezika utemeljenu isključivo na novoštokavskom govoru, bez udjela jezičnih elemenata iz čakavskoga i kajkavskoga narječja i bez udjela hrvatske književne tradicije. U tom su leksičkom i sintaktičkom sloju vidjeli smetnju književnomu jedinstvu Hrvata i Srba (usp. Maretić, 1924). Hrvatske jezične tvorenice, arhaizmi i dijalektizmi, vrlo zastupljeni u književnome jeziku zagrebačke filološke škole, više neće nalaziti mjesta u tiskanim djelima.

Pravopis tiskanih djela ovisio je ponajprije o jezično-političkoj pripadnosti izdavača ili časopisa u kojem je djelo objavljeno. Pisanje Ivane Brlić-Mažuranić i izmjene koje su njezina djela doživljavala kod izdavača nisu iznimka. S Matoševim je djelima vrlo slično. Tako priređujući Djela A. G. Matoša 1935. Antun Barac napominje (Barac 1935: 269):

Taj [Matošev] je pravopis trebalo ujednačiti to više, što se Matoš u svome pisanju nije pridržavao jednih istih principa. Pravopis ovih njegovih knjiga i nije bio toliko pravopis Matošev, koliko pravopis novina i časopisa u kojima je koja stvar bila štampana. Tako u „Iverju“ i „Novom iverju“ nalazimo na pr. ovakvo pisanje: bit će, biti će, biće; smieh, svjetlo, vijeran, nasmijehne; djačtvo, prokletca, doleće (mj. doletje); ne će i neće, itd.

Sagledamo li tako iz mnogih kutova vrlo kompleksnu jezično-političku situaciju prvih desetljeća dvadesetoga stoljeća, bit će nam jasan način pisanja Čudnovatih zgoda šegrta Hlapića uglavnom u skladu s jezičnim postavkama zagrebačke škole. 
Postaje nam jasnija i nedosljednost u provođenju jezičnoga načela - kad autorica piše Hlapića, već dvadeset godina traje pritisak vukovskoga jezičnoga izražavanja koji dakako da je izmijenio pisanu praksu. Ili je barem ozbiljno načeo ionako ne prečvrst okvir dotadašnje ortografske tradicije pisanja hrvatskim jezikom.

Nedosljednost, neujednačenost, raznolikost pisanja, što pokazuje i Matošev primjer, $\mathrm{u}$ tom vremenu nametanja novoga identiteta jezikom, bila je uobičajena i razumljiva. Ivana Brlić-Mažuranić nije bila zadovoljna kad su joj jezik 'povukovili', pokušavala je, svjedoče pisma, zadržati jezik koji je baštinila. Isto tako, opet svjedoče pisma, nije se agresivno protivila mijenjanju jezika (usp. Majhut 2010: 164). Onodobna je pisana praksa poznavala i jedno i drugo.

\section{Utjecaj obiteljske i literarne tradicije na književnoumjetnički izričaj Ivane Brlić-Mažuranić}

U razumijevanju jezika i načina pisanja Ivane Brlić-Mažuranić ne smije se zaboraviti na utjecaj obiteljske mažuranićevske tradicije na njezin jezični i književnoumjetnički razvoj, te utjecaj literature, posebno hrvatske literarne baštine.

Ivana Brlić-Mažuranić i sama je često isticala uraslost u mažuranićevsku duhovnu i kulturnu tradiciju i misao. Stariji brat njezina djeda ilirski je gramatičar Antun Mažuranić, blizak suradnik i u jezičnim pitanjima istomišljenik Ljudevita Gaja. Djed spisateljičin - Ivan Mažuranić u sve svoje aktivnosti uključuje i jezična pitanja, ali je i aktivan sudionik jezične politike druge polovice devetnaestoga stoljeća. Supotpisnik je Bečkoga dogovora 1850., iako treba istaknuti da se sam nije držao tamo donesenih jezično-pravopisnih postavaka i da se poslije odrekao Karadžićevih shvaćanja jezika Hrvata i Srba (usp. Vince 2002: 567). Kao kancelar 1862. sudjelovao je u donošenju naredbe Dvorske kancelarije o upotrebi ilirskoga pravopisa u hrvatskim školama. Tu je Mažuranić propisao pravopis zagrebačkih pisaca, svojih osobnih i političkih sumišljenika (usp. Vince 2002: 568). Njegov prijatelj Veber Tkalčević bio je vođa zagrebačke škole hrvatskih jezikoslovaca, koja je nastavila ilirske jezične ideje, one u koje su Mažuranići duboko ukorijenjeni.

Odgojena u tom duhu i na pisanoj kulturi zagrebačke škole Ivana BrlićMažuranić piše: pretiesne, mlieko, služkinja, lahko, sgode... Zaključuje slično i Stjepan Babić u svojoj analizi jezika Ivane Brlić-Mažuranić te piše da je Ivana Brlić-Mažuranić (1995: 70):

[...] u 19. st. prošla zagrebačku filološku školu, ne doduše redovitim školovanjem nego velikim čitanjem i životom u snažnoj kulturnoj sredini, ali se upravo na početku njezina književnog djelovanja zbila znatna promjena u hrvatskome književnom jeziku, napuštanje zagrebačke filološke škole, prihvaćanje hrvatskoga književnog jezika kako su ga oblikovali hrvatski vukovci, prijelaz s morfonološkoga (korijenskoga) pravopisa 
na fonološki (fonetski) i zato je važno znati kako se sve to odrazilo na njezin jezik, kakav je on s gledišta današnje norme i kako se postupa s njenim jezikom nakon njezine smrti.

\section{Zaključak}

Rukopis romana Čudnovate zgode šegrta Hlapića svjedoči o supostojanju pravopisnih rješenja zagrebačke filološke škole i rješenja hrvatskih vukovaca u pisanoj praksi hrvatskoga jezika na početku 20. stoljeća. Ivana Brlić-Mažuranić nije $\mathrm{u}$ tome iznimka među onodobnim hrvatskim književnicima. Raznolikost pisanja odlika je pisane prakse zadnjih dvaju desetljeća devetnaestoga i prvih dvaju desetljeća dvadesetoga stoljeća, a ne neujednačenosti pisanja Ivane BrlićMažuranić. Lektorske izmjene tekstova u skladu s pravopisnim i stilskim načelima hrvatskih vukovaca, činjene pri objavljivanju, dokinule su tu raznolikost pa Stjepan Babić s pravom primjećuje: „Općenito je poznato da hrvatske pisce 19. st. ne možemo čitati u izvornom jeziku jer je njihov jezik poslije pobjede hrvatskih vukovaca posuvremenjivan“ (1995: 70). Autorica Šegrta Hlapića piše dominantno hrvatskim književnim jezikom u duhu zagrebačke filološke škole, obilato se koristeći arhaizmima, dijalektizmima (kajkavizmima) i poetizmima, koji su u prvotisku izmijenjeni u skladu s vukovskom jezičnom stilizacijom. Sudbina romana Čudnovate zgode šegrta Hlapića Ivane Brlić-Mažuranić time ocrtava stanje jezika, pisane kulture i jezične politike na početku dvadesetoga stoljeća.

Provedena analiza i usporedba jezičnih obilježja rukopisa i prvotiska Čudnovatih zgoda šegrta Hlapića pokazuje da je Ivana Brlić-Mažuranić, poput brojnih drugih onodobnih pisaca, slijedila utvrđenu praksu hrvatskoga književnoga jezika u tradiciji zagrebačke filološke škole, ali i unosila elemente jezika hrvatskih vukovaca koji je u vrijeme pisanja Šegrta Hlapića već dvadeset godina u službenoj upotrebi. Jezik njezina rukopisa, poput rukopisa drugih suvremenika, dokumentira supostojanje i sukobljavanje dviju koncepcija hrvatskoga književnoga jezika početkom dvadesetoga stoljeća. Nadalje, promjene u prvotisku romana Čudnovate zgode šegrta Hlapića, načinjene u odnosu na rukopis, narušile su izvorna jezična obilježja toga književnoga djela. Te promjene također jasno pokazuju smjer mijenjanja hrvatskoga književnoga jezika, diktiran jezičnopolitičkim razlozima.

\section{Popis literature}

\section{Primarna literatura}

Brlić-Mažuranić, Ivana. 1913. Čudnovate zgode šegrta Hlapića: pripovijest za djecu. Zagreb: Hrvatski književno-pedagoški zbor.

Brlić-Mažuranić, Ivana. 1922. Čudnovate zgode šegrta Hlapića: pripovijest za djecu. Zagreb: St. Kugli. 
Brlić-Mažuranić, Ivana. 2010. Čudnovate zgode šegrta Hlapića. U Sabrana djela Ivane Brlić Mažuranić. Romani, prir. Berislav Majhut i Sanja Lovrić, ur. Vinko Brešić, 9-155. Slavonski Brod: Ogranak Matice hrvatske.

\section{Sekundarna literatura}

Anić, Vladimir. 2003. Veliki rječnik hrvatskoga jezika. Zagreb: Novi Liber.

Babić, Stjepan. 1995. „Jezik Ivane Brlić-Mažuranić: Za autentične tekstove hrvatskih pisaca“. Jezik, 42 br. 3. 69-78.

Barac, Antun (prir.). 1935. Djela A. G. Matoša: Iverje, Novo iverje. Knjiga I. Zagreb: Binoza, nakladni zavod.

Bogišić, Vlaho, Lada Čale Feldman, Dean Duda, Ivica Martičević. 1998. Leksikon hrvatske književnosti. Zagreb: Naprijed.

Broz, Ivan. 1892. Hrvatski pravopis. Zagreb: Kraljevska hrv.-slav.-dalm. zemaljska vlada.

Broz, Ivan i Franjo Iveković. 1901. Rječnik hrvatskoga jezika, I-II, Zagreb: Štamparija Karla Albrechta (Jos. Wittasek).

Brozović, Dalibor. 2008. Povijest hrvatskoga književnog i standardnoga jezika. Zagreb: Školska knjiga.

Galić, Maja. 1997. Matoševa probrana pisma iz Ženeve i Pariza. Zagreb: Tiskara „Franjo Kluz".

Majhut, Berislav. 2010. „Napomene uz kritičko izdanje“. U Sabrana djela Ivane Brlić Mažuranić. Romani, ur. Vinko Brešić, 157-189. Slavonski Brod: Ogranak Matice hrvatske.

Maretić, Tomo. 1924. Hrvatski ili srpski jezični savjetnik za sve one, koji žele dobro govoriti i pisati našim jezikom. Zagreb: Jugoslavenska akademija znanosti i umjetnosti.

Marotti, Bojan. 2010. „Je li Vidrić doista pisao »jugoslovenskim esperantom«?“. U Kolo 1-2 (2010), 124-151.

Pranjković, Ivo. 2006. Filološki vjekopisi. Zagreb: Disput.

Rječnik hrvatskoga ili srpskoga jezika. 1880-1976. I-XXIII. Zagreb: JAZU.

Sablić-Tomić, Helena i Goran Rem. 2003. Slavonski tekst hrvatske književnosti. Zagreb: Matica hrvatska.

Vince, Zlatko. 2002. Putovima hrvatskoga književnog jezika: Lingvističko-kulturnopovijesni prikaz filoloških škola i njihovih izvora. Zagreb: Nakladni zavod Matice hrvatske.

\section{Jelena Vignjević}

University of Zagreb, Faculty of Teacher Education

Universität Zagreb, Fakultät für Lehrebildung

\section{Specific Linguistic and Stylistic Features of the Manuscript and the First Printing of Čudnovate zgode šegrta Hlapića in the Context of the Linguistic History of Croatian}

A parallel reading of the original manuscript and of the first printing of the novel Cudnovate zgode šegrta Hlapića [The Strange Adventures of Hlapich the Apprentice] by Ivana BrlićMažuranić reveals that the changes in the text made in the printed version disrupted many special features of the author's writing at the levels of both language and style. This paper 
presents the results of an analysis of these specific features of the manuscript and the first printing, and interprets them in reference to the situation of the Croatian written language and the culture of writing at the beginning of the $20^{\text {th }}$ century. The parallel existence of the Zagreb philological school with its variant of the standard language and orthographic principles, and of the philological school of the Croatian vukovci, as well as the polemic arguments between them, resulted in particular writing practices at the time. The changes in the manuscript made in the first printing of the analysed novel clearly reflect the direction of the politically influenced changes of the Croatian standard language.

Keywords: Čudnovate zgode šegrta Hlapića, Ivana Brlić-Mažuranić, manuscript, first printing, Zagreb philological school, the philological school of the Croatian vukovci

\section{Sprachlich-stilistische Besonderheiten des Manuskripts und Erstdrucks von Čudnovate zgode šegrta Hlapića und deren sprachgeschichtlicher Kontext}

Aus dem Vergleich des Manuskripts von Čudnovate zgode šegrta Hlapića [Wunderbare Reise des Schusterjungen Clapitsch] mit seinem Erstdruck geht hervor, dass in den im Erstdruck enthaltenen sprachlichen Abänderungen des Textes zahlreiche sprachlich-stilistische Merkmale des Manuskripts vernachlässigt wurden. Im Beitrag wird ein sprachlichstilistischer Vergleich zwischen Manuskript und Erstdruck vorgenommen und auf dessen Grundlage die Rechtsschreibpraktiken in Kroatien zu Beginn des 20. Jahrhunderts erörtert. In diesem Zusammenhang lässt sich feststellen, dass das Nebeneinanderbestehen der konkurrierenden Sprachkonzeptionen bzw. Rechtsschreibnormen der ,Zagreber philologischen Schule' und der, kroatischen Vuk-Anhänger' eine sehr eigentümliche Rechtsschreibpraxis hervorgebracht hat. Die im Erstdruck des Romans enthaltenen Änderungen referenzieren klar auf tagespolitischen Forderungen, aus denen die Veränderung des kroatischen Sprachkorpus resultierte.

Schlüsselwörter: Čudnovate zgode šegrta Hlapića, Ivana Brlić-Mažuranić, Manuskript, Erstdruck, Zagreber philologische Schule, philologische Schule der kroatischen VukAnhänger 

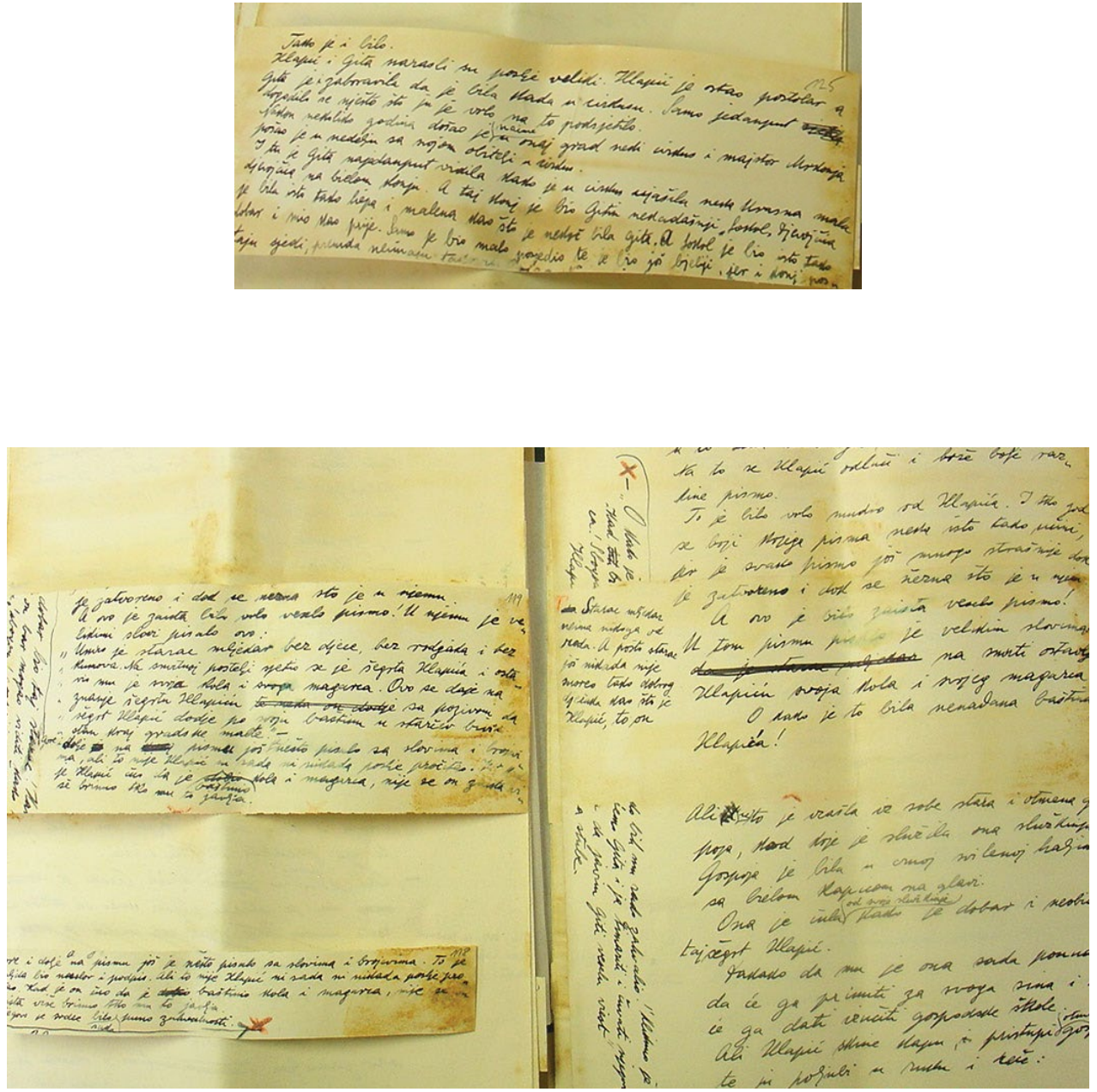

Arhiv obitelji Brlić, kutija inv. br. 82, svežnjić 8 .

Rukopis romana Čudnovate zgode šegrta Hlapića Ivane Brlić-Mažuranić. Detalji.

Original manuscript of The Strange Adventures of Hlapich the Apprentice by Ivana Brlić-Mažuranić. Details. 


\section{Spomenka Štimec}

Hrvatski savez za esperanto, Zagreb

esperanto@zg.t-com-hr

\section{Azijsko putovanje Šegrta Hlapića na krilima esperanta}

Stručni rad / report paper

Primljeno / received 14. 9. 2013.

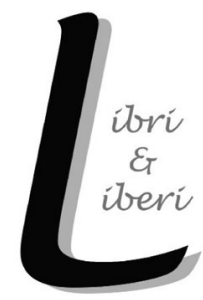

U radu se opisuju okolnosti nastanka prijevoda Čudnovatih zgoda šegrta Hlapića Ivane Brlić-Mažuranić na esperanto, pod naslovom Mirindaj aventuroj de metilernanto Hlapić (1998). Prikazuje se potom odjek toga prijevoda Maje Tišljar u esperantskim krugovima i okolnosti u kojima je Hlapić s esperantskoga kao posrednoga prijevoda preveden na japanski, bengalski, kineski, perzijski, vijetnamski i korejski jezik. Pokazuje se kako je Hlapić uz pomoć esperanta postao dostupan velikom broju čitatelja širom svijeta.

Ključne riječi: Čudnovate zgode šegrta Hlapića, Ivana Brlić-Mažuranić, esperanto, književni prijevod, posredni prijevod, azijski jezici, hrvatska dječja književnost

\section{Uvod}

Nakon što je 1912. Fran Kolar Krom iz Bjelovara, pod naslovom Trezoro de l' orajisto, tiskao u Zagrebu esperantski prijevod Šenoina Zlatarevoga zlata, dugačak je popis hrvatskih književnih djela prevedenih na esperanto. Riječ je o prijevodima književnih djela na međunarodni jezik koji je nastao krajem devetnaestoga stoljeća prema zamislima poljskoga liječnika židovskoga podrijetla Ludwika Lazara Zamenhofa (1859. - 1917.). Govorna se zajednica esperantista danas okuplja u stotinama klubova i udruženja na svim kontinentima, u kojima se razmjenjuju i čitaju knjige na esperantu, a među njima i one prevedene s hrvatskoga jezika.

Nijedna knjiga hrvatske dječje književnosti nije doprla do toliko čitatelja kao roman Čudnovate zgode šegrta Hlapića Ivane Brlić-Mažuranić, bilo u esperantskom prijevodu Maje Tišljar, pod naslovom Mirindaj aventuroj de metilernanto Hlapić 
(1998), ili u prijevodima s esperanta na druge jezike. Ove, 2013. godine, kada se obilježava stotinu godina od prvoga izlaska Šegrta Hlapića iz tiska, moguće je ustvrditi da je putem esperanta, toga jezika-mosta, priča o Hlapiću postala dostupna dvjema milijardama čitatelja, nakon što je s esperanta prevedena na japanski, bengalski, kineski, perzijski, vijetnamski i korejski jezik.

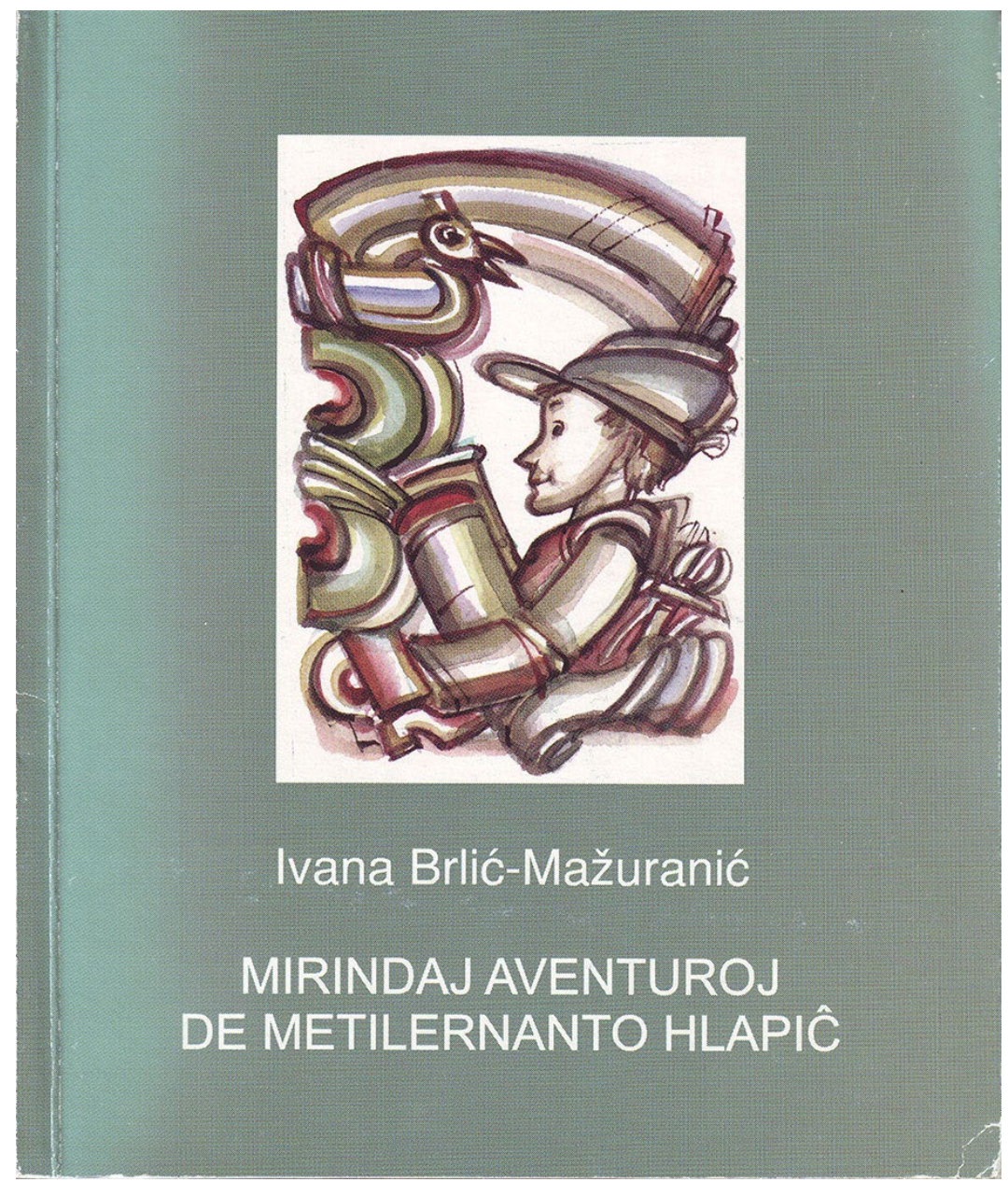

SI. 1. Korice prijevoda Hlapića na esperanto (1998).

Fig. 1 Front covers of the translation of Hlapich into Esperanto (1998).

Riječ je o vrlo tečnom i lako čitljivom prijevodu Hlapića čemu svjedoči, između ostaloga, i činjenica da je prevoditeljica Maja Tišljar odrasla u zagrebačkoj obitelji poklonika toga jezika, čije se dvoje djece odgajalo na esperantu tako da im je esperanto postao drugim materinskim jezikom. U obiteljskom okruženju čitao se 
i prijevod Hlapića riječke esperantistice Josipe Katunar, i to u rukopisu, premda se jezik toga prijevoda doimao donekle neelastičnim. Hrvatski je savez za esperanto 1997. godine, uz financijsku potporu hrvatskoga Ministarstva kulture, od Maje Tišljar, tada već studentice astrofizike, naručio novi prijevod koji je pod navedenim naslovom za tisak pripremila tvrtka LIBRO TIM esperantista Dalibora Šeatovića, a tiskala zagrebačka tiskara More. Crtež Hlapića za naslovnu stranicu knjige donirao je slikar Ivica Antolčić (SI. 1).

\section{Nagrada na Svjetskome kongresu esperantista}

Hrvatski savez za esperanto nastojao je prijevod Hlapića otisnuti što prije kako bi knjigu mogao kandidirati na natječaju Svjetskoga saveza esperantista za najbolju dječju knjigu godine. Na Svjetskome kongresu esperantista, koji se 1999. godine održavao u Berlinu, knjiga je naposljetku osvojila nagradu za najbolju dječju knjigu na esperantu. U to je vrijeme Savez istaknuo i kandidaturu Zagreba za domaćina Svjetskoga kongresa esperantista (što je i ostvareno 2001. godine te je kongres održan s nešto manje od dvije tisuće sudionika). U Berlinu je, na hrvatskome izložbenom prostoru postavljenom uz potporu Turističke zajednice grada Zagreba, bio izložen i esperantski prijevod Hlapića. Autorica ovoga rada sjeća se silnoga uzbuđenja među hrvatskim esperantistima kada je, neposredno prije proglašenja nagrade za najbolju esperantsku dječju knjigu, Osmo Buller, direktor Središnjega ureda Svjetskoga saveza esperantista, došao do hrvatskoga izložbenoga prostora i zamolio da netko dođe na proglašenje pobjednika književnoga natječaja Belartaj Konkursoj jer je knjiga o Hlapiću dobila prvu nagradu. Hlapićeva berlinska diploma danas krasi ured Hrvatskoga saveza za esperanto u zagrebačkoj ulici Kneza Mislava 11.

Potaknut Hlapićevim uspjehom u Berlinu, Savez je odlučio maloga junaka poslati još dalje u svijet. Najveća knjižara za prodaju esperantskih knjiga pri Svjetskom savezu esperantista u Rotterdamu, diljem svijeta poznata pod nazivom Libroservo, bila je prva koja je Hlapića stavila na svoje police, a knjiga je poslana i najvažnijim esperantskim časopisima u očekivanju da će u njima biti objavljeni prikazi toga romana. Ubrzo je postalo jasno da je sve to imalo odjeka i da je $̌$ Šgrt Hlapić osvojio mnoge nove čitatelje esperantiste. U nastavku opisat ćemo situacije i okolnosti u kojima su preko esperantskoga prijevoda Maje Tišljar nastajali novi prijevodi Hlapića na druge jezike.

\section{Prijevod s esperanta na japanski}

Prvi se javio japanski esperantist Sekoguchi Ken. Elektroničkom je poštom pojasnio da je on djed koji je preko esperantske knjižare pri Japanskom esperantskom 
institutu, koja se knjigama snabdijeva u Rotterdamu, kupio nekoliko dječjih knjiga kako bi unucima, kad mu dođu u goste, mogao pričati priče sa svih strana svijeta. Pročitao je Hlapića koji mu se jako svidio te je zamolio za pojašnjenje nekih pojmova iz prijevoda koji su mu bili nejasni. Odlučio je, naime, knjigu prevesti na japanski i svojim unucima, za vrijeme njihovih posjeta, čitati odlomak po odlomak. Svakako je za pohvalu ideja djeda Sekoguchija Kena da pričom o Hlapiću drži unuke podalje od šarmantnih japanskih TV-programa. O tome je 2003. godine objavljen prilog u časopisu Tempo, službenoj publikaciji Hrvatskoga saveza za esperanto. Za kakva je pojašnjenja zamolio djed iz Japana? Prevoditeljica je za opanke koje Hlapić popravlja upotrijebila esperantsku novotvorenicu koja kao takva japanskom čitatelju nije mogla biti sasvim jasna. Autorica je kao urednica esperantskoga izdanja napravila propust utoliko što već u knjizi nije dopunila izdanje objašnjenjima esperantskih neologizama sadržanih u knjizi.

Taj je propust ispravljen tako da je Davor Klobučar, urednik mrežnih stranica Saveza, na stranici Saveza postavio fotografiju slavonskih opanaka koju je predložila esperantistica Olgica Tomik, zaposlenica na Institutu za etnologiju i folkloristiku. Na stranice je Saveza postavljena i bilješka o književnici Ivani Brlić-Mažuranić, njezine fotografije s raskošnim šeširom, ali i bilješka o Bundašu jer su i o njemu čitatelji-prevoditelji postavljali pitanja. To, međutim, nisu bile jedine nedoumice na koje je Hlapić nailazio kao susretište različitih kultura. Japanski je djed primjerice imao problema i sa sintagmom ,gradski zid“.

Djed Sekoguchi Ken nije se zadovoljio samo čitanjem japanskoga Hlapića unucima. Svoje je prevoditeljsko iskustvo o hrvatskoj dječjoj književnosti podijelio i s kolegama iz Esperantskoga kluba u Mishimi. Priča se očito svidjela i drugim članovima te je odlučeno da se japanski prijevod djeda Sekoguchija, pod naslovom Shokunin-minarai Furapitchi no fushigina bouken, objavi kao malo izdanje ovoga esperantskoga kluba. Članica toga kluba, Goto Masako, oslikala je to prvo japansko izdanje Hlapića tiskanoga pod simbolom „baika-mo“ (vodenoga trešnjinoga cvijeta - ranunculus aquatilis L. var. japonicus Nakai), endemskoga cvijeta koji raste u okolici Mishime.

U Pekingu je 2004. godine, na sjednici Esperantskog komiteta autorici ovoga rada, koja je ondje zastupala Hrvatski savez za esperanto, prišla esperantistica Tahira Masako iz Kiota, bratskoga grada gradu Zagrebu. Sa sobom je donijela paketić koji šalje Sekoguchi Ken. Bila su to dva primjerka prvoga japanskoga Hlapića ukrašena crtežima Goto Masake. Tako je Hlapić na japanskome stigao i u Zagreb.

To malo plavo izdanje Hlapića ohrabrilo je prevoditelja na još jedan veliki korak: Sekoguchi Ken zaključio je da bi svome japanskome Hlapiću mogao priskrbiti bolju opremu i tako mu omogućiti da dopre do još većega broja 
čitatelja. Kontaktirao je izdavačku kuću Shinpu-sha, koja je za knjigu pronašla profesionalnoga crtača, a izdanje ukrasila izvornim naslovom Čudnovate zgode šegrta Hlapića, kao i portretom Ivane Brlić-Mažuranić, koji je za japansko izdanje u prikladnome formatu posudila zagrebačka izdavačka kuća Školska knjiga. Ovo je drugo japansko izdanje iz 2005. godine raskošnije opremljeno od prvoga. Pokazalo se da je Sekoguchi Ken, kako je autorica kasnije doznala, potrošio milijun jena da bi u toj izdavačkoj kući dao otisnuti tako raskošno izdanje Šegrta Hlapića. Japanske novine Mainichi Shinbun i Shizuoka Shinbun objavile su potom reklamu za Hlapića, tiskanu u ukupno četiri milijuna primjeraka tih novina.

\section{Bengalski prijevod - Hlapić u Indiji}

Hlapić, međutim, tu nije stao. Judita Rey Hudeček, predsjednica Hrvatskoga saveza za esperanto, autoricu je upozorila na intervju Abira Dasgupte objavljen u esperantskom časopisu Juna Amiko. Abir Dasgupta sin je uglednoga indijskoga esperantista i lingvista Probala Dasgupte, odgajan u esperantskome okružju dok je njegov prvi jezik bengalski. Juna Amiko, esperantski časopis za učenike, koji u Budimpešti izlazi od 1974. godine, intervjuirao je Abira i pitao ga što čita na esperantu. Tada desetogodišnji školarac, dječak je ustvrdio da bi sva djeca trebala pročitati Čudnovate zgode šegrta Hlapića. Ali kako ima plašljive djece, neka djeca ne mogu zamisliti da odu od kuće. Takva djeca neka čitaju Družbu Pere Kvržice, savjetovao je Abir vršnjacima koji govore esperanto. Odista je to bila lijepa reklama koju je mali Indijac učinio hrvatskoj dječjoj književnosti u međunarodnom časopisu. Družbu Pere Kvržice Mate Lovraka preveo je na esperanto Josip Pleadin 1998. godine. Taj je prijevod objavljen s crtežima Vlade Mlinjarića i pogovorom Zdravka Seleša u izdanju izdavačke kuće Grafokom iz Đurđevca.

Dodatna je zanimljivost da je Abir kao svoju četvrtu omiljenu knjigu naveo roman Kuтеuaua, sin prašume Tibora Sekelja. Tibor Sekelj, doduše, ne pripada hrvatskoj književnosti, niti je roman o malome brazilskome Indijancu Kumeuaui napisao u Zagrebu. Međutim, bio je zagrebački esperantist - upravo je u Zagrebu, gdje je živio od 1927. do 1937. godine, naučio esperanto koji je njegovo djelo o brazilskome dječaku Kumeuaui učinilo esperantskom knjigom prevedenom na najviše tj. više od trideset jezika.

Abirova oca, Probala Dasguptu iz Kolkate, ${ }^{1}$ autorica ovoga rada susrela je 2004. godine u Göteborgu u Švedskoj, i tada ga je zamolila da Hlapića prevede na

Probal Dasgupta ispravlja ime Kalkuta u Kolkata jer je to, kaže, službeni naziv grada od 2000. Prednost daje i imenu zemlje Bharat, umjesto naziva Indija. Kada se kaže Indija, daje se prednost jeziku hindu nad svim drugim jezicima koji se govore u Indiji. Kada se kaže Bharat, tim se izrazom pokriva veće područje, a ne samo ono jezika hindu. Pritom taj izraz podsjeća i na ep Mahabharatu. 
bengalski. Riječ je o jeziku koji govori 230 milijuna ljudi te je po broju govornika među prvih sedam jezika na svijetu. Probalu je pitanje bilo upućeno u trenutku kad je osjećao posebnu obvezu prema ocu, bengalskome povjesničaru Arunu Dasgupti. Naime, njegov je nedavno preminuli otac kao povjesničar bio inspiriran Mahatmom Gandhijem i njegovom mišlju kako spasiti indijsko gospodarstvo. Mahatma Gandhi je, prema Arunu Dasgupti, počevši od dvadesetih godina prošloga stoljeća poticao svoje sunarodnjake na to da se svaki dan pola sata posvete tkanju kako bi time istaknuli svoj ponos i želju za ostvarenjem neovisnosti od Velike Britanije, koja je najprije uništila tekstilnu industriju Indije, a potom Indijcima nametnula englesku tkaninu. Polazeći od Gandhijeve misli, Arun Dasgupta predložio je svim obrazovanim stanovnicima svijeta da svaki dan pola sata prevode. Na taj će se način istaknuti dostojanstvo svijeta i utjecati na razmjenu misli.

I tako se Probal Dasgupta, američki student Noama Chomskoga, primio prevodilačkoga posla pod egidom svojega oca: svaki dan pola sata, kako bi pomogao protoku ljudske misli i razmjeni ideja. Može se pretpostaviti da je Probal dodatno zadovoljstvo nalazio u prevođenju s maloga hrvatskoga jezika preko esperanta kao jezika-mosta na veliki bengalski jezik.

Dasguptin je prijevod Šegrta Hlapića otisnut u brojevima 145 do 148 bengalskoga časopisa za mladež Samatat za 2005. i 2006. godinu. Naziv časopisa Samatat znači 'jednak' (sama) i 'obala' (tat) tj. 'zajednički podij' što ujedno predstavlja i staro ime bengalske zemlje. Samatat u tome smislu predstavlja regiju od koje su nastale dvije državne tvorevine: Zapadni Bengal u Indiji i Bangladeš, koji je do 1971. bio Istočni Pakistan. U časopisu se objavljuju eseji iz književnosti, povijesti, medicine, filozofije, znanosti, tehnologije, lingvistike i glazbe, ali i biografije i dramski tekstovi. Ovaj časopis izlazi od 1969. godine četiri puta godišnje. Bengalski je Hlapić objavljivan u dijelu časopisa upućenom djeci, pod nazivom Kishor samatat, a prvi nastavci pojavili su se u brojevima za listopad i prosinac 2005. godine.

S izdavačem toga časopisa Dasgupta je dogovorio da se Hlapić, pod naslovom Hlapicher Kaando, izda i u obliku knjige, što se 2006. godine i dogodilo. To se izdanje obično naziva ,prvim bengalskim izdanjem“ pri čemu se zanemaruje da je Hlapić prvobitno bio tiskan u nastavcima u časopisu.

U jesen 2006. prvi je paket Hlapića, s gusto tiskanim bengalskim slovima, dospio i u prostorije Hrvatskoga saveza za esperanto. Skromno izdanje ilustrirano je crtežima Goto Masako, istima onima kojima je Sekoguchi Ken ukrasio prvo japansko izdanje. Tako je Hlapić poslužio i za ostvarenje japansko-bengalske suradnje. Prevoditelj Probal Dasgupta prijevod je posvetio esperantskim prijateljima Jorgeu Camachu iz Španjolske i Stenu Johanssonu iz Švedske. 
Dasgupta je organizirao svečanost predstavljanja bengalskoga Hlapića u Nehruovom muzeju u Kolkati, a u programu je sudjelovao i hrvatski veleposlanik u Indiji Dino Debeljuh. Tijekom zagrebačke proslave povodom pojavljivanja bengalskoga izdanja Čudnovatih zgoda šegrta Hlapića, upriličene u Centru za dječju knjigu 14. studenoga 2006. godine, Sulekha Pollak, Indijka i 'zagrebačka snaha', pročitala je na bengalskom odlomak iz knjige. Također se moglo čuti kako indolog Ivan Andrijević pripovijeda o oduševljenju Ivane Brlić-Mažuranić Indijom. Radnja njezina posljednjega romana, Jaša Dalmatin - potkralj Gudžerata, odvija se u indijskoj sjeverozapadnoj državi Gudžeratu. Sama je Ivana došla slušati Rabindranatha Tagorea, kada je gostovao u zagrebačkom Glazbenom zavodu sredinom studenoga 1926. godine, bilježeći slogove bengalskoga koje je tom prigodom čula. Po njezinim su bilješkama indolozi mogli i rekonstruirati koje je pjesme Tagore tada čitao. Književnica se dopisivala s velikim bengalskim piscem, dobitnikom Nobelove nagrade. Njegova se prepiska s Ivanom čuva kao dio njezine ostavštine u Hrvatskoj akademiji znanosti i umjetnosti dok su Ivanina pisma upućena Rabindranathu Tagoreu izgubljena.

Ovdje ne staje Hlapićev put. Izvršna agencija za obrazovanje, audiovizualne medije i kulturu (The Education, Audiovisual and Culture Executive Agency EACEA) Europske komisije u Bruxellesu 2007. godine raspisala je natječaj za projekt u području međunarodne kulturne suradnje Europske unije, u kojemu je kao obvezatna partnerska zemlja bila predviđena Indija. Hrvatski savez za esperanto u tom je trenutku bio jedini Savez pri Svjetskome savezu esperantista koji je mogao sudjelovati u tome natječaju budući da je ispunjavao bitan uvjet: ostvarenu kulturnu suradnju s Indijom prije 2007. godine i već postojeći tim suradnika u toj zemlji. Za to je najbolji dokaz bio upravo bengalski Hlapić.

Probal Dasgupta u Kolkati je prihvatio poziv iz Zagreba da vodi indijski dio tima pri čemu se u izradi projekta ostalo na području dječje književnosti. Zacrtan je plan o prevođenju jednoga djela indijske dječje književnosti na tri europska jezika i po jednoga djela dječje književnosti iz tih triju europskih jezika na bengalski jezik. Bilo je predviđeno predstavljanje prevedenih knjiga u školama triju europskih zemalja, odnosno u školama u Indiji. Mali će čitatelji pisati eseje o knjigama koje su pročitali, a najbolji eseji objavit će se i nagraditi. Kako ne postoje književni prevoditelji s, primjerice, bengalskoga na hrvatski jezik ili sa slovenskoga na bengalski, kao posredni prijevodi poslužit će upravo oni na esperanto. Ta i nobelovac Rabindranath Tagore preveden je u Hrvatskoj preko jezika-mosta, a ne direktno iz bengalskoga na hrvatski jezik.

U Hrvatskom je savezu za esperanto s oduševljenjem primljena odluka Agencije Europske komisije o izboru upravo njihovoga projekta za koji je u 
Bruxellesu odobreno nešto više od 33.000 eura, a toliku je sumu trebao osigurati i sam Savez. Čini se da je 33.000 eura najveći iznos za neki posao u kojemu je sudjelovao postolarski šegrt Hlapić.

U projektu je zagrebački tim okupio kolege iz Slovenije i Italije, a pridružili su se i Inter-kulturo, ustanova esperantista Zlatka Tišljara iz Maribora, prevoditelj Vinko Ošlak iz Celovca i izdavačka kuća Edistudio iz Pise. Partner u Kolkati bila je izdavačka kuća Samatat. Voditeljica projekta bila je Spomenka Štimec iz Hrvatskoga saveza za esperanto, a u radu je sudjelovala i esperantistica Vera Roknić. Hrvatski partner-izdavač bila je izdavačka kuća Izvori iz Zagreba s prevoditeljem Domagojem Vidovićem.

Slovenski je partner predložio knjigu Tone Partljiča Hotel sam prijeti sonce [Htio sam uhvatiti sunce] iz 1981. godine, talijanski knjigu Il Giornalino di Gian Burrasca [Mali dnevnik Giana Burrasce] koju je 1912. godine objavio Vamba (Luigi Bertelli, 1848. - 1920.), a iz hrvatske dječje književnosti izabran je roman Waitapu (1984.) Jože Horvata (1915. - 2012.) budući da je 2005. godine s partnerima u Wuhanu već bilo tiskano i kinesko izdanje te Horvatove knjige. Bengalski partner predložio je knjigu Damoruov život ${ }^{2}$ iz 1923. godine, bengalskoga autora Troilokyanatha Mukhopadhyaya (1847. - 1919.). Projekt je trajao od 2008. do 2010. godine s obvezom dovršenja do 30. travnja 2010. što je i učinjeno.

\section{Na perzijskome tepihu}

No, Hlapić je putovao i drugamo, a da bi ga se moglo pratiti, potrebno je vratiti se malo vremenski unatrag. Na povratku iz Adelaidea u Australiji, 1997., dok se zrakoplov približavao sjeveru kontinenta, autorica ovoga rada prošetala je prolazom nakon dugoga sjedenja. U zadnjem dijelu zrakoplova ugledala je znanicu iz Irana koja se, kao i ona, vraćala kući sa Svjetskoga kongresa esperantista. Bila je to iranska esperantistica Akhtar Etemadi. Srdačni je susjed pristao zamijeniti svoje mjesto s autoričinim te je imala priliku nekoliko sati čavrljati s Akhtar. Doznavši da se bavi prevođenjem, autorica je već imala ponudu za nju: bi li s esperanta prevodila djela iz hrvatske književnosti na farsi (perzijski)? Autorici privremeno nedostupna Antologio de kroataj unuaktaj dramoj [Antologija hrvatskih jednočinki] iz 1998. godine ležala je u kovčegu u utrobi zrakoplova, ali je Akhtar ubrzo dobila paket hrvatskih knjiga na esperantu.

Prevoditeljica je iz navedene antologije najprije prevela jednočinku „Gogoljeva smrt“ Ulderika Donadinija, a potom „Ljubavi Georgea Washingtona“ Mire Gavrana.

2 Djelo je na hrvatski jezik s esperanta preveo Domagoj Vidović, a objavljeno je u Zagrebu 2009. godine. Naslov je preveden s izvornika Damru-Charita, a na esperanto je knjigu prevela Malasree Dasgupta pod naslovom La vivo de Damoru. 
Kasnije je prevela i Hlapića. Perzijski Hlapić, objavljen pod naslovom Majera Hay ŝegeft angizz Hlapic ŝagert kafaŝ, ukrašen grafikama poznatoga perzijskoga umjetnika Mohammada Reze Lavasanija, otisnut je u Teheranu u nakladi od 10.000 primjeraka pa je, kako kaže prevoditeljica, dostupan malim čitateljima i u selima širom Irana. Izdavačka kuća, u kojoj je Akhtar Etemadi 2005. objavila perzijskoga Hlapića, ugledna je iranska kuća Kanoon Parvaresh Fekri Koodakan iz Teherana koju je još prije islamske revolucije osnovala iranska carica Farah Diba.

Akhtar Etemadi bila je 2005. godine gošća Hrvatskoga saveza za esperanto na Susretu pisaca u Hrašćini, a Novi list tiskao je intervju s prevoditeljicom.

\section{U Vijetnamu}

Sljedeći je Svjetski kongres esperantista bio u Firenzi, ljeti 2006. godine. Autorica je unaprijed dogovorila susret s vijetnamskim predstavnikom na Kongresu pa se Nguyen Xhuan Thu uoči otvaranja Kongresa pojavio na hrvatskome štandu da preuzme svoj primjerak Hlapića. Pritom je postignut dogovor da preporuči dobroga prevoditelja s esperanta na vijetnamski ako mu se knjiga učini zanimljivom za vijetnamsku publiku.

U zadnjem tjednu veljače 2007., dok se u esperantskome svijetu obilježavao Tjedan međunarodnoga prijateljstva, iz Hanoja je stigla vijest da je skupina mladih prevoditelja završila prevođenje hrvatske knjige Čudnovate zgode šegrta Hlapića. Mladi vijetnamski esperantisti učili su esperanto uz pomoć zagrebačkoga udžbenika esperanta pa su se u sklopu svoga jezičnoga obrazovanja bavili Hlapićem. Kasnije je došla i vijest da je partner Vijetnamskoga esperantskoga saveza u projektu objavljivanja vijetnamskoga izdanja Hlapića Vijetnamsko udruženje pisaca. Nguyen Xuan Thu, koji je knjigu iz Firenze odnio u Vijetnam, osobno je nosio rukopis u tiskaru. Neposredno uoči predaje materijala u tiskaru poslao je još jednu elektroničku poruku uznemirujućega sadržaja: "Pregledavam materijal prije predaje u tiskaru i vidim da je crtač nacrtao crnoga Bundaša?! Pa Bundaš je smeđe boje, zar nije?“

Knjiga je tiskana 2008. godine pod naslovom Cuộc phiêu lư kỳ lạ của chú bé học viềc Hlapic, a izašla je iz tiska prigodom vijetnamske proslave Međunarodnoga dana djeteta. Prevoditelji, potpisani u vijetnamskom Hlapiću, su Phan Hong Vuong i Luong Ngoc Bao. Jezik prijevoda provjerio je Nguyen Xuan Thu. Urednik izdanja bio je Cao Truong. Tekst je za tisak pripremio The Minh. Crteže za tu knjigu načinio je Nguyen The Minh koji se poslužio pseudonimom The Quang.

Kada je četiri godine kasnije, 2012. godine, Hanoj bio domaćin Svjetskoga kongresa esperantista, Hrvatski savez za esperanto organizirao je kongresni 
program o Hlapiću. Judita Rey Hudeček, predsjednica Hrvatskoga saveza za esperanto, održala je s vijetnamskim kolegama program u kongresnoj knjižari, o kojemu je izvijestio i bilten Kongresa.

\section{Dugi boravak u Kini}

Moramo svratiti i u Kinu gdje je naš suradnik Shi Cheng Tai 2002. godine pripremao kineski prijevod knjige 7000 dana u Sibiru Karla Štajnera, prema esperantskom prijevodu Krešimira Barkovića. Esperantski primjerak knjige, tiskan u Parizu pri esperantskoj organizaciji S.A.T. (Sennacieca Asocio Tutmonda), poslao je svome prijatelju Shi Cheng Taiu u Harbin, na sjever Kine, ugledni japanski esperantist Kurisu Kei koji je svojega kineskoga prijatelja često znao darivati odabranim knjigama. Shi Cheng Tai bio je opčinjen sibirskom temom. Debela knjiga autentičnih Štajnerovih sibirskih doživljaja sporo se pretakala s esperanta na kineski. Autorica je prevoditelju u Hrvatskoj pribavila i pogovor Predraga Matvejevića za buduće izdanje knjige. Pritom je Shi Cheng Tai zamolio da mu se pošalje neka druga hrvatska knjiga uz koju će se odmarati od mučnih sibirskih scena. Dobio je odmah Hlapića uz kojega će se, kako je bilo mišljeno, doista moći odmarati. Dirljiv je bio događaj 2004. godine, kada su uvaženi kineski prevoditelji Shi Cheng Tai i Hu Guo dočekali autoricu ovoga teksta na ulazu u pekinški kongresni centar i uručili joj zeleni paket kineskoga izdanja Štajnerove knjige 7000 dana $u$ Sibiru, i to uz dodatak. Naime, kada je završio prijevod i kada je započelo mukotrpno rješavanje problema tiskanja toga izdanja, Shi Cheng Tai je javio da je gotov i kineski prijevod Hlapića. Tek je tada postalo jasno da se od prevođenja Štajnera kineski prevoditelj odmarao prevodeći Ivanu Brlić-Mažuranić! Zamoljen, Shi Cheng Tai je poslao primjerak svojega prijevoda, uvezanoga u knjigovežnici Šoban, koji se danas nalazi u arhivu manuskripta knjižnice Hrvatskoga saveza za esperanto.

Taj je rukopis čekao izdavača skoro cijelo desetljeće. U međuvremenu je ponuđen za objavljivanje izdavačima na nekolikim kineskim adresama. Bez uspjeha. Pokušaji su urodili plodom tek kada je hrvatski veleposlanik u Pekingu postao Ante Simonić. Veleposlanstvo je javilo da je zainteresirano za objavljivanje kineskoga prijevoda Hlapića te da je našlo suradnika za taj izdavački projekt, kao i slikara koji će knjigu oslikati. Isprva se činilo da će Čudnovate zgode šegrta Hlapića izdati kakva kineska izdavačka kuća za dječju književnost, no knjigu je Veleposlanstvo objavilo samostalno, u Pekingu 2012. godine, pod naslovom Xiaoxuetu Helapiqi lixianji. Hrvatski veleposlanik Simonić u nekoliko je navrata posjećivao pekinške škole s kineskim Hlapićem u ruci kako bi djeci približio hrvatsku kulturu. 
Shi Cheng Tai se vrlo obradovao kineskomu Hlapiću i malomu honoraru koji je dobio zahvaljujući Ministarstvu kulture. Uskoro je Savez preko esperantskih krugova saznao da je, prije ovoga izdanja, već 1982. godine tiskano izdanje Hlapića na kineskom jeziku, pod naslovom Labiqi chuzouji. To izdanje nije prevedeno s esperanta, već vjerojatno s engleskoga jezika. Prevoditelj nije bio bilo tko - bio je to slavni pisac, prevoditelj i esperantist Cicio Mar. Njegov sin, poznat u kineskom esperantskom pokretu pod pseudonimom Freŝa Maro (Svježe More), javio je da ne zna s kojega je jezika njegov otac preveo djelo. Esperantski časopis Tempo objavio je u listopadu 2013. godine članak prevoditeljeva sina o ocu-esperantistu koji je prvi preveo Hlapića na kineski jezik.

\section{Diljem svijeta}

Prijevodi Čudnovatih zgoda šegrta Hlapića, nastali iz esperantskoga prijevoda, nastavljaju posredovati među kulturama koje spajaju. O tome svjedoče i mnogi susreti koji su povodom toga romana održani u novije vrijeme. Primjerice, povodom stotoga rođendana romana o šegrtu Hlapiću održana je svečanost u zagrebačkome Centru za dječju knjigu uz predstavljanje kineskoga Hlapića zagrebačkim učenicima. O Hlapićevim pustolovinama po Aziji govorila je Judita Rey Hudeček, a odlomak iz romana na kineskom jeziku pročitao je Marin Mikulić.

Također, posebni hommage Ivani Brlić-Mažuranić održan je u travnju 2013. u Pusanu, u Koreji: tamo je suradnik Hrvatskoga saveza za esperanto objavio korejsko izdanje Čudnovatih zgoda šegrta Hlapića pod naslovom Kkoma gudujang-i Heullapichi. Među korejskim esperantistima poznat pod imenom Ombro, Jang Jeong-Ryeol je s Hrvatskim savezom za esperanto uspješno surađivao i 2012. godine kada je, uz stotu obljetnicu rođenja Tibora Sekelja, u Seulu objavio svoj korejski prijevod romana Китеиаиа - sin prašume. U 2013. godini uspio je prevesti Hlapića i objaviti korejsko izdanje u svome gradu Pusanu, u izdavačkoj kući Sanzin. Crteže Hlapićevih pustolovina za to izdanje pripremila je Lee Da-Jeong.

Predstavljanje ovoga izdanja u Hrvatskoj organizirano je u zagorskom selu Hrašćini $^{3}$ u svibnju 2013. godine, uz pomoć Veleposlanstva Republike Koreje koje je hrvatskoj publici omogućilo da čuje kako zvuči korejski Hlapić. Uvodnu riječ o Hlapiću održali su Vinko Brešić i Berislav Majhut, a uz priču o Hlapiću u Aziji, koju je ispričala autorica ovoga teksta, čuli smo i po odlomak iz perzijskoga Hlapića, koji je čitao Farhang Monem, i iz kineskoga, koji je čitao Marin Mikulić.

3 Predstavljanje je održano u sklopu Susreta meteorita. "Meteoritski“" književni susreti u autoričinoj se hraščinskoj kuriji redovito održavaju od 1995. godine. Naime, u Hrašćini je 26. svibnja 1751. godine pao meteorit pa se Susreti održavaju u spomen na taj događaj koji je ujedno obilježio početak znanstvenoga istraživanja meteorita. 
Odlomak iz hrvatskoga izvornika pročitala je glumica Barbara Rocco. Osim toga, iranska prevoditeljica ponovno je došla u Hrvatsku u rujnu 2013. i sudjelovala na Susretu esperantskih pisaca i prevoditelja koji je bio ograniziran od 14. do 16. rujna 2013. godine, također u Hrašćini.

Hrvatski savez za esperanto upriličio je i hommage Hlapiću u raskošnom kongresnom centru Harfa u Reykjaviku 23. srpnja 2013. godine, na Svjetskom kongresu esperantista. Kongresni bilten pod nazivom Auroro, aludirajući na nordijsko svjetlo u svom nazivu, najavio je ovaj kongresni događaj. Govorilo se o prijevodima Hlapića u Aziji i o „Projektu Hlapić“ Hrvatskoga saveza za esperanto (usp. Kroata Esperanto-Ligo). O bengalskom prijevodu govorio je Probal Dasgupta. Japanski prevoditelj Sekoguchi Ken nije mogao prisustvovati pa je poslao zamjenika, mladoga japanskoga književnika koji je na Kongres došao s fotografijom cvijeta baika-mo iz grada Mishime pod čijim je imenom prvi japanski Hlapić ugledao svjetlo dana. Kineski i korejski prevoditelji nisu mogli nazočiti skupu, no o njihovim prijevodima Hlapića govorila je autorica ovoga rada. U publici, u Reykjaviku, sjedio je i jedan Nepalac sa svojom poznatom šarenom kapom. Došao je čuti što se sve Hlapiću događa u Aziji. Imao je sitne brčiće i smješkao se. Zove se Bharat. Ali s Nepalom su razgovori tek započeli. Daleko je Katmandu...

Svemu tome mogu se dodati i druga svježa sjećanja na Reykjavik, povezana s Hlapićem. U kongresnoj knjižari u Reykjaviku Svjetski savez esperantista prodavao je esperantskoga Hlapića. Kupac iz Kostarike molio je da mu se napiše posveta. Kupac iz Kanade priložio je novčanicu kao potporu Savezu, samo zbog Hlapića. Bengalski prevoditelj Probal Dasgupta, kojem je istekao mandat predsjednika Svjetskoga saveza esperantista pa je u programu o Hlapiću sudjelovao prvi puta kao bivši predsjednik, zamolio je za novi primjerak esperantskoga Hlapića budući da se njegov pri prevođenju prilično oštetio.

Danas Hrvatski savez esperantista, udruga koja od 1998. godine provodi projekt „Čudnovate zgode šegrta Hlapića u Aziji“, teško nalazi sredstva za nove pothvate. Je li Hlapić završio svoj azijski krug na kojemu ga je pratio esperanto? Nadajmo se da nije, no kakav god bio odgovor na to pitanje, autorici je drago što mu je na tome putu otvarala vrata.

\section{Popis literature}

Brlić-Mažuranić, Ivana. 1982. Labiqi chuzouji. Prijevod na kineski Cicio Mar. Hunan: [Izdavačka kuća za djecu].

Brlić-Mažuranić, Ivana. 1998. Mirindaj aventuroj de metilernanto Hlapić. Prijevod s hrvatskoga na esperanto Maja Tišljar. Ilustracija na naslovnici Ivica Antolčić. Zagreb: Hrvatski savez za esperanto/Kroata Esperanto-Ligo. 
Brlić-Mažuranić, Ivana. 2004. Shokunin-minarai Furapitchi no fushigina bouken. Baikamo. Prijevod na japanski Sekoguchi Ken. Ilustracije Masako Goto. Mishima: Esperanto-Klubo Mishima, Japan.

Brlić-Mažuranić, Ivana. 2005. Shokunin-minari Furapitchi no fushigina bouken. Prijevod na japanski Sekoguchi Ken. Ilustracije Akino Junko. Tokio: Shinpu-sha.

Brlić-Mažuranić, Ivana. 2005. Majera Hay ŝegeft angizz Hlapic ŝgert kafaŝ. Prijevod na perzijski Akhtar Etemadi. Teheran: Kanoon Pervareshh Fekri Koodakan.

Brlić-Mažuranić, Ivana. 2006. Hlapicher Kaando. Prijevod na bengalski Probal Dasgupta. Ilustracije Goto Masako. Kolkata: Samatat.

Brlić-Mažuranić, Ivana. 2006. Cuộc phiêu luu kỳ la của chú bé học viềc Hlapic. Prijevod na vijetnamski Phang Hong Vuong i Luong Ngoc Bao. Ilustracije The Guang. Hanoj: Udruga vijetnamskih pisaca i Vijetnamski esperantski savez.

Brlić-Mažuranić, Ivana. 2012. Xiaoxuetu Helapiqi lixianji. Prijevod na kineski Shi Cheng Tai. Peking: Veleposlanstvo Republike Hrvatske.

Brlić-Mažuranić, Ivana. 2013. Kkoma gudujang-i Heullapichi. Prijevod na korejski Jang Jeong-Ryeol. Ilustratorica Lee Da-Jeong. Izdavačka kuća Pusan: Sanzin Book.

Kroata Esperanto-Ligo (KEL). Hrvatski savez za esperanto. $<$ http://www.esperanto.hr/> (pristup 10. rujna 2013.).

\section{Spomenka Štimec}

Croatian Esperanto Association, Zagreb

Kroatischer Esperanto-Bund, Zagreb

\section{The Asian Journey of Hlapich the Apprentice on the Wings of Esperanto}

The paper reveals the circumstances of the appearance of the Esperanto translation of the 1913 Croatian children's classic Čudnovate zgode šegrta Hlapića [The Strange Adventures of Hlapich the Apprentice] by Ivana Brlić-Mažuranić, titled Mirindaj aventuroj de metilernanto Hlapić (1998). It records the wide popularity of this translation by Maja Tišljar in international Esperanto circles and chronicles the events which led to further translations of Hlapich from this one as a relay translation into Japanese, Bengali, Chinese, Persian, Vietnamese and Korean. It is shown how Hlapich the Apprentice has become accessible to a large number of readers around the world through Esperanto.

Keywords: The Strange Adventures of Hlapich the Apprentice, Ivana Brlić-Mažuranić, Esperanto, literary translation, relay translation, Asian languages, Croatian children's literature

\section{Asienreise von Šegrt Hlapić auf den Flügeln des Esperanto}

Im Beitrag werden die Umstände dargelegt, unter denen die 1998 unter dem Titel Mirindaj aventuroj de mitilernanto Hlapić veröffentlichte Esperanto-Übersetzung des kroatischen Kinderromans Čudnovate zgode Šegrta Hlapića [Wunderbare Reise des Schusterjungen 
Clapitsch] von Ivana Brlić-Mažuranić entstanden ist. Ferner wird über die Nachwirkungen dieser von Maja Tišljar geleisteten Übersetzung in internationalen Esperanto-Kreisen berichtet, sowie über die Umstände, unter denen der Roman vom Esperanto ins Japanische, Bengalische, Chinesische, Persische, Vietnamesische und Koreanische übersetzt wurde, wodurch der kroatische Hlapić mit Hilfe von Esperanto weltweit neue Leserkreise erschließen konnte.

Schlüsselwörter: asiatische Sprachen, Čudnovate zgode šegrta Hlapića, Esperanto, literarische Übersetzungen, Mirindaj aventuroj de metilernanto Hlapić 


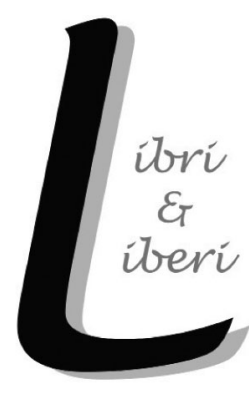

\section{Građa \\ Fact File}





\section{Letters about Hlapich}

\section{Prepared and edited by Berislav Majhut and Sanja Lovrić Kralj}

This contribution consists of letters which either refer to or at least mention Čudnovate zgode šegrta Hlapića [The Strange Adventures of Hlapich the Apprentice], whether as a novel or as a dramatization or play, and which were written during the lifetime of Ivana Brlić-Mažuranić (1874 - 1938). In addition to the letters, two contracts and a list of performances of the play Hlapich the Apprentice are also included.

The collection comprises 84 texts, i.e. letters by Ivana Brlić-Mažuranić sent to other persons (31/84), letters by other persons to Ivana Brlić-Mažuranić (43/84), as well as letters which mention Hlapich, but in which Ivana Brlić-Mažuranić does not appear at either end of the correspondence (10/84), such as the correspondence of the Kugli publishing house with Želimir Mažuranić, an interesting postcard by A.G. Matoš, the leading Croatian Modernist poet, sent to Henrijetta Mažuranić, or the letter by Josip Bach, director of drama at the Croatian National Theatre, to Ivo Brlić, Ivana Brlić-Mažuranić's son. However, the ceremonial congratulatory messages for the writer's sixtieth birthday on the occasion of the premiere of Hlapich the Apprentice at the Croatian National Theatre are omitted.

The letters and other texts are presented in chronological order, starting with the first letter that mentions the word 'Hlapić', when it was not yet clear what this word really referred to (the letter written by Ivana Brlić-Mažuranić to her daughters, probably in 1905), and the letter mentioning "a longish narrative" from the Croatian Pedagogic-Literary Assembly addressed to Ivana Brlić-Mažuranić in 1906. The most recent letter given here was written in 1935.

The letters are annotated with only the most necessary explanations regarding the sender or the receiver. There is also a partial Brlić-Mažuranić family tree, which can help understand the family relations of some of the correspondents involved and of the persons mentioned in the letters.

The following archives have been explored in search of the letters:

The Croatian State Archives, Zagreb, The Family Brlić Archives on microfilm

The Collection of Archives of the Croatian School Museum, Zagreb (HŠM)

The Mažuranić-Brlić-Ružić Memorial Library and Collection, Villa Ružić, Rijeka

The Brlić Memorial Archives and Library, Slavonski Brod

The Archives of the Department of the History of Croatian Literature of the Institute for the History of Croatian Literature, Theatre and Music of the Croatian Academy of Sciences and Arts, the Legacy of Ivana Brlić-Mažuranić 
We are grateful to all these archives for permission to publish the texts of the letters and other materials, as well as the facsimiles and photographs which accompany the text in this issue of Libri \& Liberi.

The editors of the collection also wish to express their gratitude to the following: Tihomir Engler for the translations of and comments on the parts of the letters written in German, and to Jasna Rebrović for her translations from French; Theodor Canziani Jakšić, custodian of the Mažuranić-Brlić-Ružić Memorial Library and Collection in Rijeka, who made a valuable contribution through his own search for letters and comments; Jasna Ažman and Tatjana Melnik who supported this project through their work at the the Brlić Memorial Archives and Library in Slavonski Brod; and Dina Alexandra Pavković and Nika Vučić for their help in the initial stages of this project.

\section{Pisma o Hlapiću}

\section{Priredili Berislav Majhut i Sanja Lovrić Kralj}

U ovaj pregled uvrštena su pisma koja se tiču Šegrta Hlapića ili se u njima spominje Šegrt Hlapić (bilo kao roman, bilo kao dramatizacija), a napisana su za života Ivane Brlić-Mažuranić (1874. - 1938.). Osim pisama uvrštena su dva ugovora te popis predstava Šegrta Hlapića.

U ovoj zbirci tekstova (84 teksta) nalaze se pisma Ivane Brlić-Mažuranić upućena drugim osobama (31/84), pisma drugih osoba Ivani Brlić-Mažuranić (43/84), ali i pisma u kojima se spominje Hlapić, a Ivana Brlić-Mažuranić nije uključena ni na jednome kraju korespondencije (10/84), kao što je primjerice prepiska nakladničke kuće Kugli sa Želimirom Mažuranićem ili pak zanimljiva dopisnica A. G. Matoša Henrijetti Mažuranić, ili pismo Josipa Bacha, ravnatelja Drame Hrvatskoga narodnoga kazališta (HNK) Ivi Brliću, sinu Ivane BrlićMažuranić.

Nisu uvrštene protokolarne čestitke povodom šezdesetoga rođendana Ivane Brlić-Mažuranić kada je u HNK-u bio izveden Šegrt Hlapić.

Pisma su poredana kronološki od prvoga spominjanja riječi Hlapić, kad ne znamo na što se točno ta riječ odnosi u pismu Ivane Brlić-Mažuranić kćerima, vjerojatno 1905., te spominjanja jedne „oduže pripovijesti“ u pismu Hrvatskoga pedagoško-književnoga zbora upućenom Ivani Brlić-Mažuranić 1906. pa do posljednjega pisma iz 1935. godine.

Uz pisma su navedeni tek najnužniji komentari koji se odnose na onoga koji šalje ili pak prima pisma, ili na osobe koje se u pismima spominju. I rodoslovlje 
Ivane Brlić-Mažuranić reducirano je na najnužnije u svrhu razumijevanja pisama. Arhivi kojima smo se koristili:

Hrvatski državni arhiv, Zagreb, u kojemu je na mikrofilmovima pohranjen Arhiv obitelji Brlić

Arhivska zbirka Hrvatskoga školskoga muzeja, Zagreb (dalje u tekstu: HŠM) Spomenička knjižnica i zbirka Mažuranić-Brlić-Ružić, Villa Ružić, Rijeka Spomenički arhiv i knjižnica Brlić, Slavonski Brod

Arhiv Odsjeka za povijest hrvatske književnosti Zavoda za povijest hrvatske književnosti, kazališta i glazbe HAZU, u kojemu je pohranjen dio ostavštine Ivane Brlić-Mažuranić.

Svim navedenim institucijama zahvaljujemo na suglasnosti za objavljivanje prijepisa pisama i drugih materijala, kao i na ustupanju prava na objavljivanje slikovnih materijala u ovome broju časopisa Libri \& Liberi.

Priređivači zahvalnost također duguju Tihomiru Engleru na prijevodima i komentarima dijelova pisama pisanih na njemačkom jeziku, te Jasni Rebrović na prijevodima s francuskoga jezika. Theodor de Canziani Jakšić, skrbitelj Spomeničke knjižnice i zbirke Mažuranić-Brlić-Ružić u Rijeci, pomogao nam je ne samo potragom za pismima, već i svojim komentarima. Jasna Ažman i Tatjana Melnik su nam pomogle radom u Spomeničkom arhivu i knjižnici Brlić. Zahvalnost za pomoć u ranoj fazi rada dugujemo i Dini Alexandri Pavković te Niki Vučić. 


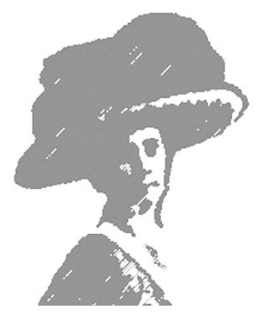

\section{RODOSLOVLJE IVANE BRLIĆ-MAŽURANIĆ}

(uključuje osobe koje se spominju u pismima)

The Family Tree of Ivana Brlić-Mažuranić

(mostly covering persons mentioned in the letters)

Ivan Mažuranić (hrv. ban)

(1814. - 1890.) $+\quad$ Aleksandra Mažuranić, r. Demeter (ca. 1820. - 1885.)

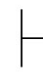

Vladimir Mažuranić

$+\quad$ Henrijetta (Jetti, Jetika) r. von Bernath Lendway

(1845. - 1928.)

(1842. - 1919.)

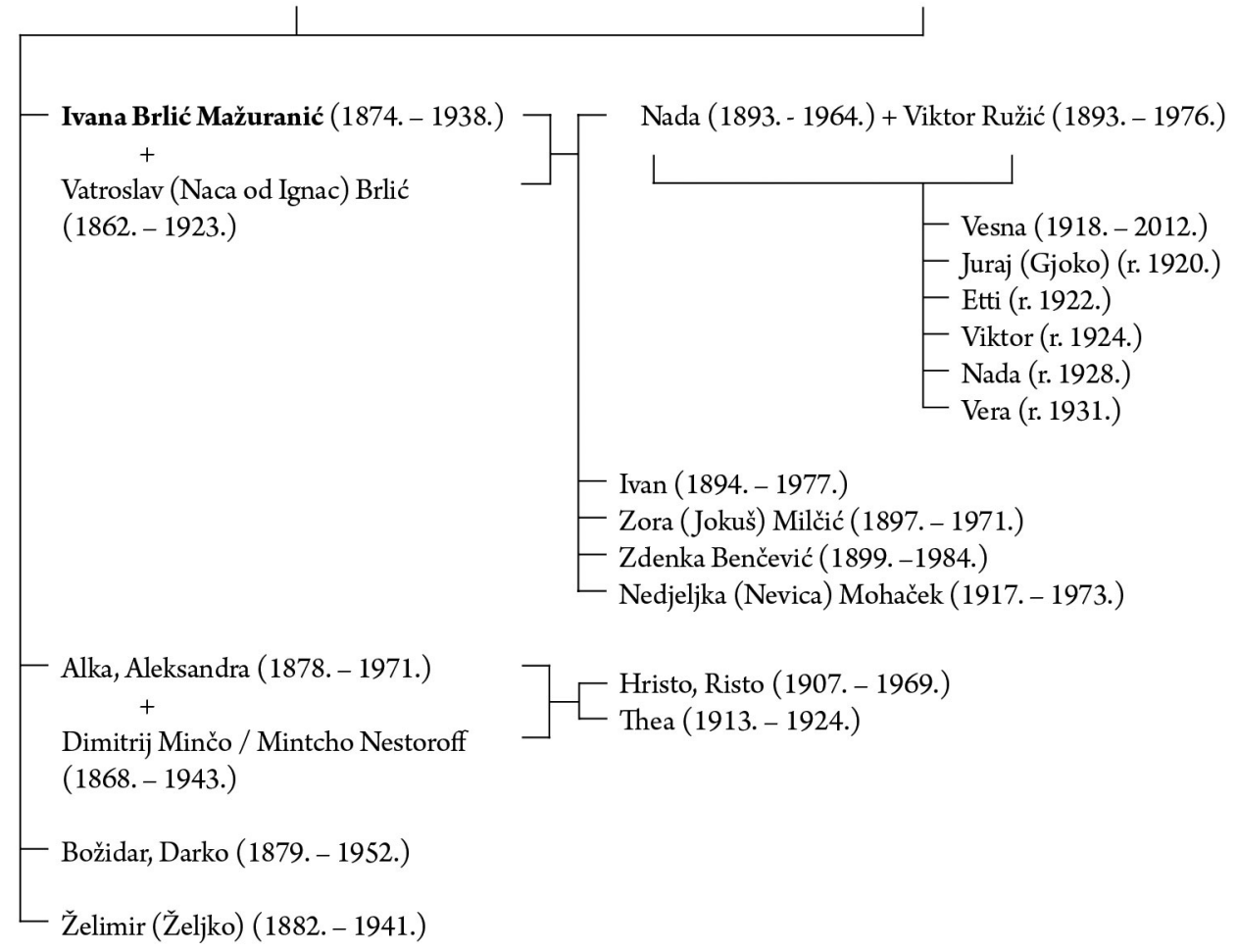


oko 1905.

\section{Drage moje curice ${ }^{1}$ !}

Vaša pisma vrlo su me obradovala i to $s$ razloga što vidim da ste tako pametne da već za $1 \frac{1}{2}$ dana znate toliko toga! Već znate jeli[sic] vam liepo ili nije, ima li izgleda za aventure ili neima ${ }^{2}$ - već znate da je kuharica izvrstna gospodarica i da neima pomoći proti stjenicama koje još niste ni vidili. O kako je pametan taj Hlapić! I kako je nagradjen za svoju mudrost! Već su mu se prvi dan izlegle i mačke i pišćenci! Dajte kanape van, okefajte ih u pukotinama, namažite i naprašite zaherlinom pak probajte spavati. Ja mislim da će biti za 5-6 dana kraj tomu zlu. Ako pako ne - a vi prenesite dolje one željezne postelje odozgor da vam bude „ljepše“ negoli samima gore! Nadina biela leinen oprava se danas pegla, a u ponedjeljak dolazi švelja. Kupila sam za Zoru i Zdenku leinen žućkasti za bluze. Kako nekoć ona Nadina tennis oprava sa šarenim vezivom takav je leinen.

Staroj mami hvala Bogu sbilja svaki dan bolje. Bože daj samo da potraje! Možda se onda i mi oko 1. o. mj. vidimo - bar na neko vrieme ili stalno. Želite li si Miru ili Danu?-

Internat će sada biti gdje je bio licej - a licej tamo gdje je bila preparandija - u doljnjem gradu! - Upravo strašna bedastoća.

Grlim tatu i Zdenkicu i vas dvie.

Mama.

[U Arhivu obitelji Brlić pismo je umetnuto u svežnjić s naslovom: „Pisma I. B. M upućena kćerkama Nadi iz 1909. god. (6 kom) i jedno nedatirano“.]

Arhiv obitelji Brlić, kutija inv. br. 72, svežnjić 4.

\section{0. prosinca 1906.}

Blagorodnoj gospođi

Ivki Brlić Mažuranićevoj

\section{U Brodu}

Povodom Vašega vrlo cijenjenog upita čast nam je priopćiti Vam, da bi, „Hrv. pedagoško-književnomu sboru“ bilo najmilije, kad bi za nj napisali sbirku pripovijedaka poput one „Škole i praznici“ negoli veću pripovijetku, jer se manje pripovijetke uopće lakše raspačavaju, što je dokaz, da ih djeca radije čitaju.

Pismo je upućeno kćerima Ivane Brlić-Mažuranić, Nadi (r. 1893.) i Zori (r. 1897.)

2 Ivana Brlić-Mažuranić negaciju i glagol najčešće piše spojene u jednu riječ pa tako donosimo i u prijepisima njezinih pisama. Stoga u daljem tekstu ovu pojavu nećemo posebno označavati. Označujemo očite zatipke dok ćemo druge pojave, koje se mogu tumačiti kao greške u prepisivanju, a ponavljaju se, označiti samo kod prvoga pojavljivanja. 
No podjedno nam valja spomenuti, da se ta knjižica prije g. 1908 ne bi mogla štampati, jer za godinu 1907. imade Zbor u pripravi drugih već prihvaćenih spisa.

Vaš rukopis iščekujući što skorije bilježe se sa[sic]

Upravni odbor „Hrv. pedag.-književnoga zbora“ u Zagrebu / 30. prosinca 1906.

s veleštovanjem

Predsjednik:

Stjepan Basariček
Tajnik:

Josip Kirin

Arhiv obitelji Brlić, kutija inv. br. 78, svežnjić 18.

\section{6. svibnja 1912 .}

Draga moja mamice ${ }^{3}$ !

Baš u vrieme kad imaš najveće brige sa Alkom i njezinim novim pechom- baš u to vrieme ostavila sam Te tako dugo bez lista. Nu kućni poslovi ne pitaju za veće i važnije brige, nego hoće da budu izpunjeni, a kako ne imamo služkinje ipak nešto više posla dolazi na mene.- Alki sam pisala dugačko pismo u kojem ju hrabrim i nagovaram da Minči i doktoru prepusti brigu i odgovornost za nju. To je i onako za svakog bolestnika najkomodnije- a ova operacija čini se zaista da je sada posve neopasna- osobito u onim slučajevima gdje se više čini kao preventivna a ne kao absolutno nužna. Imaš pravo da bi nakon te operacije mogle eventualno nestati i ostale neprilike- što Bože daj! Ljepše će nam svakako biti svima kad i to opet prodje! Drži me molim Te au courant [redovito me obavještavaj o aktualnim zbivanjima].

Žao mi je za Nadu da ju opet nećemo najmanje 14 dana viditi[sic]. Nu dakako da je Alka sad najvažnija. - Naša ciela familija je sada već jako nestrpljiva i gespannt ${ }^{4}$ [napeto iščekuje] na povratak Nade. Osobito Zdenka, koja ju deset put na dan spominje.

Za Ristu sam počela pisati onu knjigu, te ću Ti sutra ili prekosutra poslati prve kapitule. Zove se „Čudnovate sgode šegrta Hlapića“. Zdenki se jako dopada premda je pisana, ja držim, sasvim u niveau-u Ristinom.- Kad stvar sa Alkom, ako Bog da, dobro prodje, mogla bi Ti /: ako Ti se pripov[i]jest dopadne :/ probati sreću kod Kugli-a. Možda nam ju odkupi. To bi bila, po mom mnenju, jako dobra knjiga za djecu od 6-8 godina, a dala bi se jako sgodno ilustrirati.-

3 Henrijetta Mažuranić r. von Bernath Lendway (27. siječnja 1842. - 15. listopada 1919.), supruga Vladimira Mažuranića, majka Ivane, Aleksandre (Alke), Božidara (Darka) i Želimira. U pismima je često zovu Jetta ili Jetika.

4 Dijelove teksta na njemačkom jeziku preveo je i komentirao Tihomir Engler. 
Strašno sam pospana jer je kasno, a mi smo na današnji svetak načinili krasan izlet u jednu šumu. Ali Ti to radje neću opisivati. Es ist gefährlich den Poeten zu werken! [Opasno je probuditi pjesnika!]

Ljubim Ti ruke, mamice, i nemoj se osvetiti za moju šutnju nego mi piši.- Sobaricu neću da uzmem ovdje nego čekam blagoslov iz Zagreba.

Ivana

16/5 912. Brod n. S.

Arhiv obitelji Brlić, kutija inv. br. 70, svežnjić 15.

\section{5. svibnja 1912.}

\section{Dragi moj Nadek ${ }^{5}$}

25/5 912 .

Baš sam jutros ustala iz kreveta i pošla ravno do pisaćeg stola da Ti pišem, kad mi je stiglo Tvoje pismo. Dakako da sam onda erst recht [baš zato] ostala kod pisaćeg stola - i evo me na tom mjestu!

Velika je to bura sad došla na vas - ali ju nemojte povećavati. Nemoj misliti, mala moja, da si Ti odgovorna za išto drugo nego za svoju dobru nakanu i volju. Risto ima Fišiku, koja je upravo savršena za njega i na koju se možeš podpuno osloniti.Što se Minče tiče, njemu će glavna stvar biti da ima komu sve svoje jade i strahe izpripoviedati, i ako u tomu možeš biti strpljivi i neuzrujani slušalac, bit će mu najviše pomoženo. To sve nije tako kako si on i teta predstavljaju - to si neprestano drži pred očima i predstavi si kako bi Ti to jasno vidila kad nebi bila sama tamo nego kad bi još ja ili stara mama bili uza te. Onda ćeš odma[h] viditi kako faktične pogibelji ili razloga za strah neima. Štogod Minči i teta govore to je posljedica njihovih vječnih higienskih študia. Bože daj samo da Ti iz svega toga naučiš, kako je pretjerana higijena najgorja bolest na svietu i kako čovjeku čini nemogućim užitak života. Ako Bog da teta će se za nekoliko dana vratiti, a onda Ti i Risto čim prije k nama na jug. „Na moj povratak nemojte još misliti“ to je skoro tako kao tetino uvjerenje o neminovnoj smrti.- Kao što sama veliš, brine se teta i za Tvoj boljak neprestano, pak će sigurno, čim dodje kući, nastojati da Ti i Risto odete.- Ti si moj jako dobri frac [deran], koji u podpunoj mjeri svoju dužnost čini, samo je ta dužnost malo odviše iznenada i neočekivano došla u tako osbiljnoj formi, koju dakako kućne okolnosti povećavaju.- Stara mama mi šalje svako Tvoje pismo, i uživa u Tvojoj točnosti i potankosti. Ali zar nebi za nju i Tebe bolje bilo da svaku predmnijevu i gatanje na zlo potanko ne opisuješ? Uostalom, to ćeš Ti bolje znati, jer istina da stara mama oduvijek uživa u dobrim i lošim detaljima.-

5 Nada Ružić (31. siječnja 1893. - 2. siječnja 1964.), najstarija kći Ivane i Vatroslava Brlića. 
Da predjem od vas na nas. Kod nas je hvala Bogu dobro. Zadnje vrieme smo učinili nekoliko izleta. Bili smo jedanput u Glogovici a jedanput u Migalovačkoj šumi. Što su Migalovci lijepi to neimaš pojma. Riečju: Maksimir! Veliki stari hrastovi, pod njima tratina, dvie velike bare kao jezera - pokrivena perunikom i driemovcem jako liepo! U ostalom možda sam Ti to već i pisala.

Preko Duhova htjeli smo izseliti na dva dana u vinograd ali danas kiša sasvim osbiljno pada, pak valjda neće biti ništa. Žao mi je, jer svibanjske krasote vinograda jednostavno nedaju se opisati. Ruže cvatu kao da su u plamenu diljem staze!

Ja sam sada marljiva u pisanju. Pišem jednu pripoviest za Ristu. „Čudnovato putovanje šegrta Hlapića“. Šegrt Hlapić naime utekne od zločestog majstora Mrkonje i putuje 8 dana po svietu u zelenih hlačah, crvenoj košulji i čižmah sa sjajnimi sarami. Svašta mu se zla i dobra dogodi - a mami se to dogodilo da je već dobila komad manuskripta i telefonira con amore [požrtvovno] po Zagrebu za nakladnika.- Ovaj čas spava Hlapić pod mostom na cesti sa jednim lopovom, jer je vani oluja i noć. Grozno!

A pomisliš li da neimam već mjesec dana sobarice i da sam pače Mandi odkazala (s njenom promjenjljivom ćudi bilo je odviše borbe) onda moraš priznati da mi je još uz mnoge misli koje me okupiraju za sve vas, ovaj Hlapić krasno utočište! - U mojoj glavi se doduše križaju njegove fiktivne sgode sa pravimi i živimi sgodami koje se s vama zbivaju i vrlo često (kao n. pr. ovaj put) upotriebim komad Hlapićevog papira za njegove najozbiljnije konkurente. Neka samo gospodin Bog izvede s vama sve tako povoljno i veselo i - last non least [i ne manje važno] - tako brzo, kao što ću ja nastojati izvesti iz neprilika.

Draga moja i dobra curice, budi samo hrabra. Uvjeravam Te da si Ti sad pravi treffer [zgoditak] za Minču i za Alku - a i za nas, jer inače bi sigurno ili mama ili ja bile tako uznemirene da bi putovale u Berlin.

Ljubimo Te i grlimo svi, koj bol, taj bol!

\section{Mama}

Šaljem Ti ove krasne karte koje sam ovih dana za Te kupila. Spravi ih. Jel da su liepe! Tata ${ }^{6}$ mi nalaže da Te pozdravim s njegove strane!

Arhiv obitelji Brlić, kutija inv. br. 72, sv. 7.

$\overline{6}$ Misli se na Nadinoga ocaVatroslava Brlića (1862. - 1923.), odvjetnika i političara. 


\section{6. svibnja 1912.}

Na Duhove

26/5 912 .

\section{Brod na Savi}

\section{Dragi mamić!}

Danas sam opet primila od Tebe Nadino pismo.- Ja mislim da će se sve jako dobro svršiti, ali dakako da će se usl[i]jed prevelikih higijenskih mjera zavući ciela reconvalescencija na dva puta dulje nego bi bilo nužno.- Usl[i]jed toga mislim da bi sada bilo vrieme da se počne osbiljno govoriti o Nadinom i Ristinom putu.- Čim Alka dodje iz sanatoriuma i čim počne ustajati, moramo to pitanje odavde sasvim energično potaknuti. Iz ovih dugačkih referada koje Nada piše i opisuje, vidim da zaista u najmanje tančine proživljuje sve te strahove. Ti znaš kako je Tebi, kraj Tvojeg vanredno zdravog suda i razuma, bilo već pod zadnje kad su Alka i Minčo kod vas bili i neprestano najgorje stvari odkrivali i prorokovali. Ti si sama rekla: man weiß nicht mehr ist es so schrecklich oder nicht [više se ne zna, je li tako strašno ili ne].- Možeš si dakle misliti da Nadi mora sbilja već tiesno biti. Ovako mlado i impresivno stvorenje, obkoljeno samim uzrujanim ljudima i koje još drži da ima odgovornost za Ristu - odgovornost koju se jedva Ti usudješ preuzeti!!

Meni je vanredno drago bilo, a sigurno si i Ti zadovoljna bila, što je Nadica sa toliko srdca, čuvstva i sbilja prave ljubavi, pratila sve to, i pomagala prema silama. Čini se da su Minčo i Alka ove zime razumjeli podpuno predobiti njeno srdce i da se sbilja osjećala podpuno, i u zlu i u dobru, kao da k njima spada.-Al ovo što je dalje, mislim da će biti suvišno, a jako se bojim i štetno po Nadu. A tamo nitko neće imati ni inicijativu ni energiju da potakne pitanje odlaska. Dakle mi absolutno to moramo čim prije odavle učiniti. Ja znam da ćeš Ti to tako pametno učiniti, kako se samo može - zato Tebi tako obširno razlažem svoje razloge - a moram Ti reći da mi je to sad osbiljno na srdcu.

O mom manuskriptu drugi put.- Kako vam se dopada? Zdenki jako. Jesi li našla pismo u njemu. Piši mi

Ja bez sobarice, bez bedienerice, na pol bez Mande.- Ali malo gospodarstvo a „odrasla i kućevna“" kćerka, pak nekako ide dosta lahko.

Grlim Vas i vaša sam

Ivana.

Zagrli mi moga Jokuša ${ }^{7}$. Al bi rado š njom bila sad preko Duhova!

Arhiv obitelji Brlić, kutija inv. br. 70, svežnjić 15.

\footnotetext{
7 Nadimak Zore Milčić (22. prosinca 1897. - 15. ožujka 1971.), kćeri Ivane i Vatroslava Brlića.
} 
29. svibnja 1912.

Draga mamice!

Kao što vidim primiruje se stvar kod Alke hvala Bogu. Nu što Ti pišeš da Ti neprestano nije dobro, to mi je jako žao. Nachdem Du aber einmal bei so einer gelegenheit gesagt hast: „,ich brauch nicht so viele Worte“ [Nakon što si jednom u jednoj takvoj prigodi rekla: „Čemu tolike riječi?"] to se pravo neufam puno pisati o tomu. Nadam se doći za 14 dana u Zagreb, nu to je još jako daleko. Zato mi prosim Te ipak piši što Ti je za pravo, i kako si pomažeš sad kad si solo sa tatom. Nije li vam grdo? Piši mi po duši-- Čujem doduše posve sigurno i nepokolebivo da je tata opet jedanput postao ban hrvatski - ali zato ipak mislim da bi mu ugodno bilo da mali Risto dodje da vam oživi kuću. Meni se haltfort ${ }^{8}$ [neprestano] čini da ste odviše sami i da si Ti zato bolestna. Promisli si pravo nije li tako?- Piši mi dunque [dakle] o sebi mamice, da bar znamo kako Ti je.

Kod nas je podpuno utonuće u kućni posao. Sobarice još uviek neimamo. Manda (po mom odkazu) odlazi prekosutra, bedinerica nas je iznevjerila i tako smo nolens volens [htjeli - ne htjeli] postali Tolstoji u punom smislu rieči što se viksanja tiče i pometanja. Samo me je strah, da pri tom naše srdce nije tako blagohotno kako kod njega! - Prosim Te, zar se nijedna djevojka nejavlja iz novina? A kako to da se ona perla, sestra Gustina, nije ni javila ni došla? Ja bi platila eventualno i više nego $10 \mathrm{f}$ (respective [odnosno] 12 for.) - dala bi naime sobarici 12 a kuharici i 14 f.- ali to prepuštam Tvojoj ocjeni.

Dakako da se za sve to nemoraš prekopitnuti, dragi mamić. Da znam da si sbilja bolestna nebi ni o tom pisala, pak ovaj dio lista gilta [važi] samo onda ako si djedjerna i ratoborna - što je uviek najbolji znak. Ako dunque kakova iole pristojna djevojka dodje, šalji ju molim štante pede, bez oklievanja, da nam neuteče. Novac ću ti rembourser [vratiti, nadoknaditi], kako kaže Minčo.

O svemu ostalomu pismeno je dosadno i nespretno razpravljati. Ustmeno, ako Bog da, bolje.

Danas mi piše Matanić da će u „Drau“ izići kritika mojih „Slika“ - a ujedno da će i u Savremenik napisati isti kritičar (Krnic) kritiku. Neznam hoće li se križati s Matošem? - Piše mi Matanić neka se nesrdim da je to upriličio. Nur Lumpen sind bescheiden ${ }^{9}$ [Samo ništarije su skromni], dodaje on.

O nastavku „šegrta Hlapića“ za sada neima govora - nu kad se kućne prilike srede, bit će brzo gotovo.

Ljubim vas, draga mamice, i nadam se da nisi baš rogi bolestna.-

8 To je zastarjeli njemački izraz koji je moguće pronaći još samo u pjesmama. (op. prev. T. E.)

9 Riječ je o citatu Jahanna Wolfganga von Goethea koji čitav glasi: „Samo ništarije su skromne, odvažni se vesele djelu“. (op. prev. T. E.) 
A da znaš tko je bio kod mene ovih dana! Eugen Malinarić, comandant [zapovjednik] monitora [vrsta ratnoga broda] na Savi, dotično Dunavu. Veli da će Te posjetiti u Zagrebu. Das war ein lebhaftes Wiedersehen [Bio je to veseo susret]! Tvoja Ivana.

29/5 912. Brod na Savi.

Arhiv obitelji Brlić, kutija inv. br. 70, svežnjić 15.

31. svibnja 1912.

\section{Dragi mamić!}

Vidiš kakovi smo mi grozni ljudi, da se služinčad ćak[sic] u Zagrebu nas boji! Ima pravo ona moja bivša sobarica Julka, koja je druge odgovarala da neidu k nama jer je: „to jako opasna služba.“ - Medjutim, nemoj se dalje za nas brinuti. Ako koja dodje, pošalji ju odma, bez da me pitaš - ako ne dodje - auch gut! [također dobro!] Mi smo samo tri osobe sada, pak to nije nikakva neprilika za nas.

Meni je sbilja drago da Alkini bulletini prestaju. Sigurno te je i to očekivanje uzrujavalo, a drhtati mi nemoj - mamice! To prepusti nama, mladjem i nervoznom naraštaju - inače zaista nećemo imati uzora u koji bi se ugledali kad nas spopadne naša nervozna kukavština!

Kod nas ništa novoga. Popravljam Zdenki opravicu za tielovo. U ostalom će valjda vrieme ostati consekventno [dosljedno] svojemu pravcu - i tako će bjeline pokisnuti i dječja srdca biti razžalošćena kao često na taj dan.

Hvala Bogu da moj Jokuš tako dobro izgleda!

Ja ću valjda oko 20/6 u Zagreb. Rado bi prije, već radi Tebe /:jer znam kad dodju Risto i Nada - onda me ne trebaš tako jako:/ - ali nemogu radi Zdenke, koju bi rado sa sobom povela a koja ima školu do 20/6. I radi Ive bilo bi mi prerano prije doći. Rado bi onda naime ostala do njegovog odputovanja, pošto nezna kako bi to bez mene išlo.- Osim toga drži me za sada još i posao oko tielovskog oltara u Brodu. Moram, dakle, kako god bi rado odma poletila u Zagreb - suspreći svoje želje. Čovjek se uostalom na to susprezanje, hvala Bogu, tako nauči s vremenom, da se oni slabi glasići koji se još kadkad javljaju, više nemogu ni zvati želje!

Manuskripat leži na pisaćem stolu gospoje Kemeter i doći će prvom prilikom u posao. Hvala Bogu da je moja mišpoha [obitelj] zadovoljna sa čedom moje fantazije: Hlapićem! I Željko se za njega interesira, te me je puno o njemu pitao. Inače mi nije ništa telefonirao.

Ljubim Ti ruke mamice i Tvoja sam

31/5 $912 \quad$ Brod n. S.

Ivana.

Arhiv obitelji Brlić, kutija inv. br. 70, svežnjić 15. 


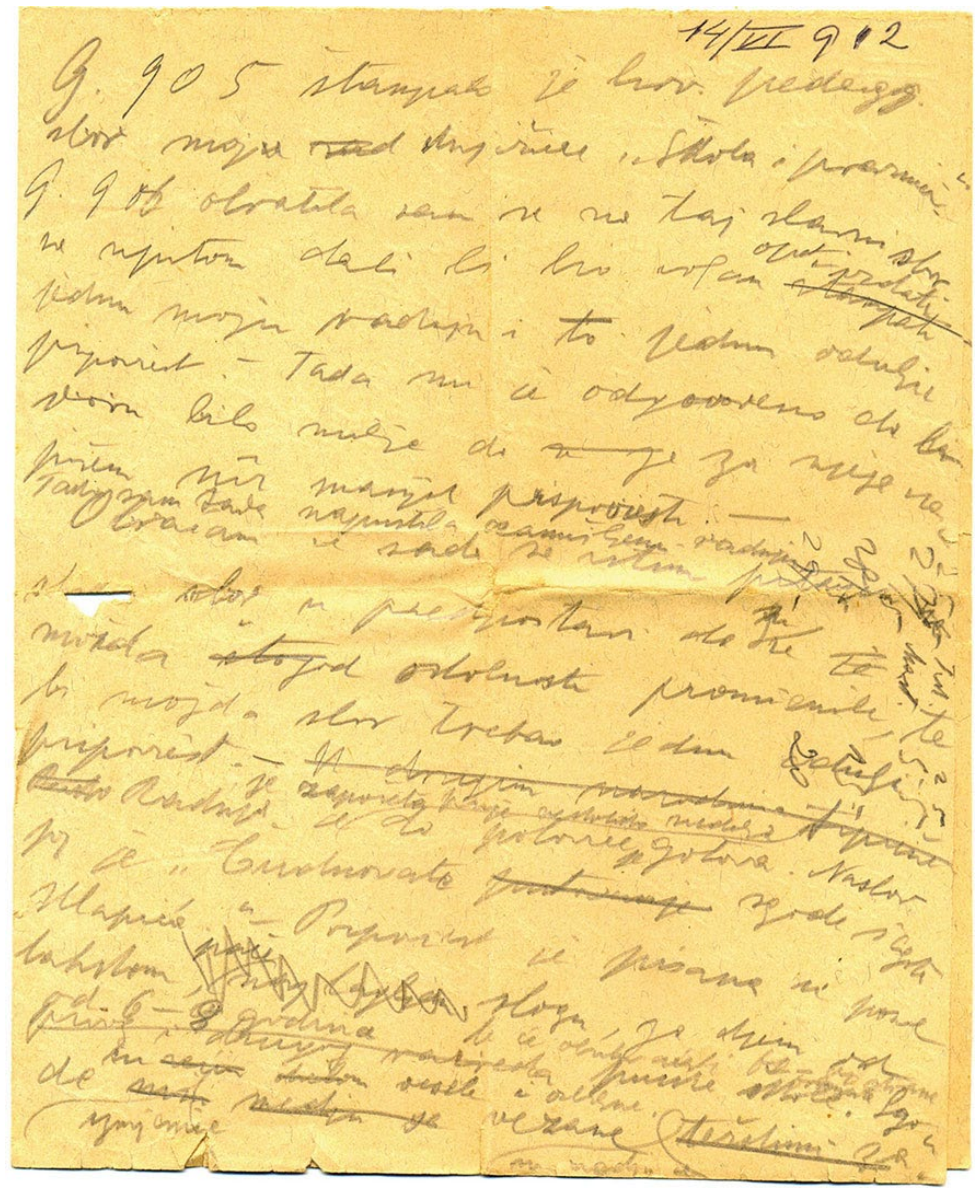

Sl. 1.a Faksimil prve stranice koncepta pisma Hrvatskom pedagoškoknjiževnom zboru od 14. lipnja 1912.

Fig. 1a Facsimile of the first page of the draft written by Ivana Brlić-Mažuranić on 14 June 1912, addressed to the Croatian Pedagogic-Literary Assembly, the publisher of the first edition of The Strange Adventures of Hlapich the Apprentice.

\section{4. lipnja 1912.}

14/VI 912.

G. 905 štampao ${ }^{10}$ je hrv. pedagožki sbor moju knjižicu „ŠKkola i praznici“. G. 906. obratila sam se na taj slavni sbor sa upitom dali[sic] bi bio voljan opet izdati jednu moju radnju i to jednu odulju pripoviest.- Tada mi je odgovoreno da bi sboru bilo milje da za njega napišem niz manjih pripoviesti.- Tako sam tada napustila zamišljenu radnju.

${ }^{10}$ Koncept pisma koje je Ivana Brlić-Mažuranić uputila Hrvatskom pedagoško-književnom zboru. 


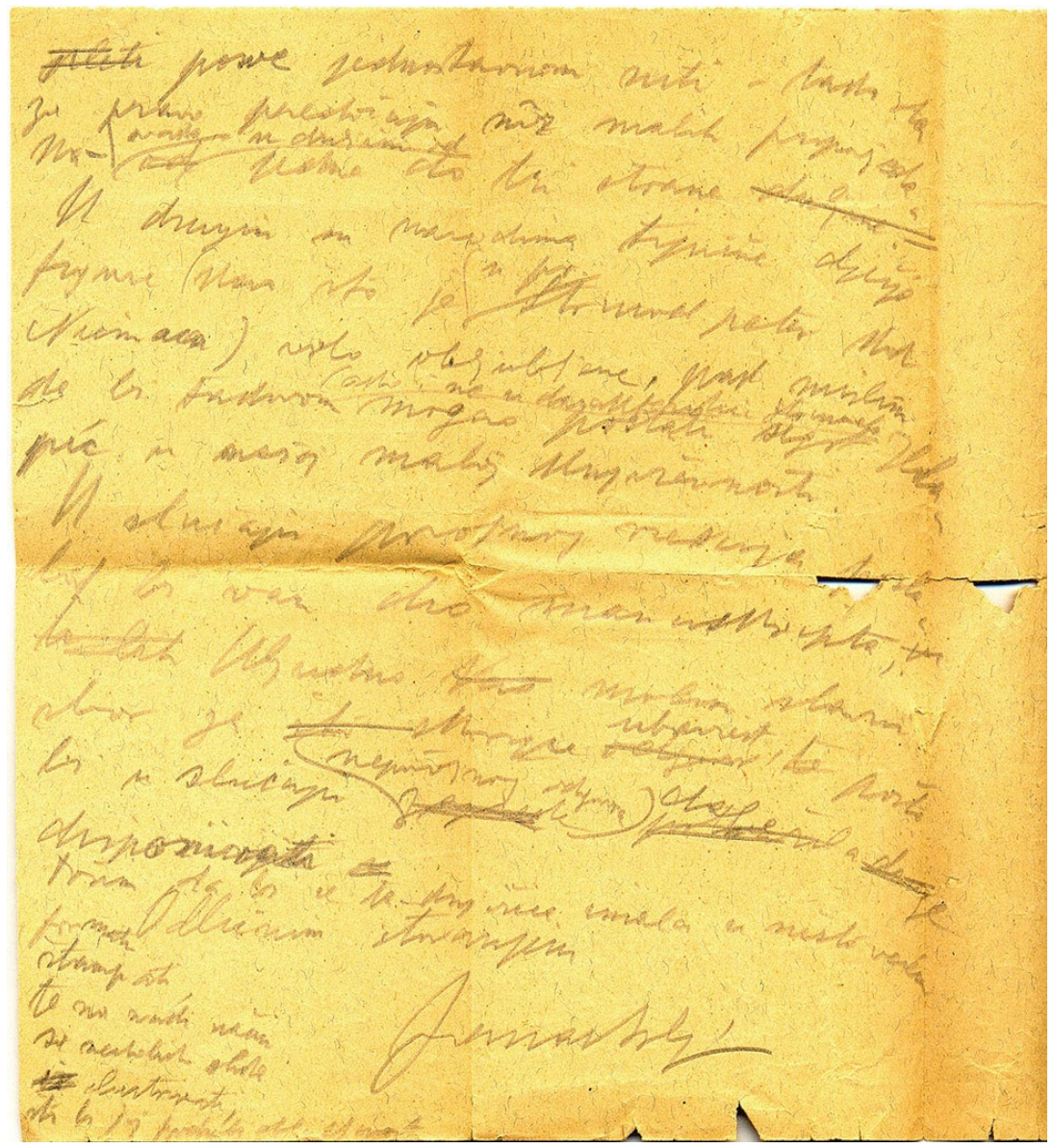

SI. 1.b Faksimil druge stranice koncepta pisma Hrvatskom pedagoškoknjiževnom zboru od 14. lipnja 1912.

Fig. 1b Facsimile of the second page of the draft written by Ivana BrlicMažuranić on 14 June 1912, addressed to the Croatian PedagogicLiterary Assembly, the publisher of the first edition of The Strange Adventures of Hlapich the Apprentice.

Obraćam se sada sa istim pitanjem na slavni sbor u predpostavci da su se možda okolnosti promienile te bi možda sbor trebao jednu odulju pripoviest. Radnja je započeta prije nekoliko ned[j]elja i do polovice gotova. Naslov joj je „Čudnovate sgode šegrta Hlapića“.- Pripoviest je pisana u posve lahkom slogu za djecu od 6-8 godina od prvog i drugog razreda pučke škole. Sgode su izmjenice vesele i osbiljne, vezane u radnju posve jednostavnom niti tako da zapravo predočuju niz malih pripoviedaka svaka u duljini od jedne do tri strane. 
U drugim su narodima tipične dječje figure (kao što je n pr. Struwelpeter kod Niemaca) vrlo obljubljene pak mislim da bi takvom [nečitko, ali vjerojatno piše: ako i ne u exzaktnom formatu] mogao postati šegrt Hlapić u našoj maloj književnosti.

U slučaju potvrdnog rješenja poslala bih vam dio manuskripta. Uljudno molim slavni sbor za skoriju ubaviest[sic] te pošto bi u slučaju nepovoljnog odgovora dalje disponirala se.

Držim da bi se ta knjižica imala u nešto većem formatu štampati te na svaki način sa nekoliko slika ilustrirati što bi joj povećalo obljubljenost.

Odličnim štovanjem

\section{Ivana Brlić}

Arhiv obitelji Brlić, kutija inv. br. 78, svežnjić 33.

18. lipnja 1912.

Broj: 62./1.912.

P. n. gospođa

Ivana Brlić-Mažuranić

Brod $\mathrm{n} / \mathrm{Savi}$

U povodu Vašega cijenj. pisma čast nam je zamoliti Vas, da nam izvolite poslati čim više od ponuđenoga rukopisa. O daljem ćemo Vas u svoje vrijeme obavijestiti. Upravni odbor „Hrv. pedagoško-književnoga zbora“

U Zagrebu, dne 18. lipnja 1.912.

Predsjednik:

Tajnik:

Josip Martinović

Josip Škavić ${ }^{11}$

Arhiv obitelji Brlić, kutija inv. br. 78, svežnjić 33.

20. rujna 1912.

Vrlo ugledna gospođo!

Poradi nekih poremećaja u odboru „Zborovu“ kao i poradi poslova na početku školske godine nije još dosada održana nijedna sjednica. Ovih dana, prema koncu mjeseca, održat će se sjednica, pa će se tom prigodom odlučiti i o Vašem rukopisu, o čemu ćete biti obav[i]ješteni

Bivši predsjednik, a i ja kao urednik „Knjižnice za mladež“, pročitali smo rukopis.

${ }^{11}$ Josip Škavić, tajnik Hrvatskoga pedagoško-književnoga zbora, tada urednik Knjižnice za mladež Hrvatskoga pedagoško-književnoga zbora i dječjega časopisa Smilje. 
Ovaj predloženi dio vrlo je lijep i djeca će ga s osobitim interesom čitati, pa ću u prvoj sjednici predložiti, da ga „Zbor“ izda za članove i to za god. 1.912. Prema tomu trebali biste, da najkasnije do polovice listopada pošaljete čitav rukopis, da knjiga bude zajedno s ostalima do početka god. 1913. dovršena.

Vaše želje u pogledu jezika i slikara također će odbor uvažiti. Pravopis će se udesiti prema današnjemu.

Izvolite mi molim Vas priopćiti što prije, hoćete li moći u listopadu rukopis poslati da mogu već sada u sjednici predložiti Vašu radnju. Ne bi li Vam bilo moguće rukopis do toga vremena poslati, morat ću predložiti koju drugu od poslanih nam radnja.

S osobiti poštovanjem

Josip Škavić

tajnik „Hrv. ped. knjiž. zbora“

Zgb. 20. 9. 912.

Pantovčak 42

[nadopisano rukopisom IBM: odg. 25/9 - da produlje rok]

Arhiv obitelji Brlić, kutija inv. br. 78, svežnjić 33.

nakon 20. rujna 1912.

\section{Dragi mamić!}

Sretno stigla. Spavali smo u Brodu i ostajemo dakako ovdje. Ovaj čas sam po Bobincu dala injicirati Zdenku i moju sobaricu (jer je ova potonja cijeli dan sjedila kod malog vincilirovog.) - Za sada nam je svima dobro- samo si možeš predstaviti koji nered ovakovo iznenadno selenje! - I jako nam je žao malog vincilirovog, koji je još uviek u velikoj opasnosti.

Javiti ću vam se opet. Dobila sam pismo da svršim „Hlapića“ do 15. oktobera - da je „vrlo liepo i da će djeca osobitim interesom čitati“. To misli učitelj Škavić.Možeš si misliti da mi je sad do Hlapića stalo!

Kako Tebi mamice i tati? Ako Bog da do skorog vidjenja. Samo javite o Hudi. Tvoja Ivana.

[Pisano odmah nakon Škavićeva pisma od 20. rujna 1912. g.]

Arhiv obitelji Brlić, kutija inv. br. 70, svežnjić 15. 
25. rujna 1912.

25/9 912 Brod n. S.

Velecienjeni gospodine ${ }^{12}$ !

Vaše cienjeno pismo primila sam, te bi mi bilo drago da ,zbor“ štampa moju pripov[i]jest uz navedene uvjete.

Jedino mi je stavljeni rok nješto prekratak, pošto ću do 6. listopada biti obiteljskimi poslovi zapriečena da nastavim pisanje.

Ako se dakle nekosi sa družtvenimi pravili, to bi mi bilo ugodno da se rok produlji do početka studena. Nije li pako to moguće, morati će se stvar ostaviti za buduću godinu.- Molim za ljubeznu ubaviest te ostajem štovanjem

Ivana Brlić

HŠM A 1081 Škavić, Josip

4. listopada 1912.

Vrlo ugledna gospođo!

Prema Vašem posljednjem pismu držim, da bi najzgodnije bilo, da Vi izvolite Vašu pripovijest polako izrađivati, pa tamo na koncu prosinca ovamo poslati. Tada bi knjiga izašla u svibnju 1.913. Tako bismo imali dovoljno vremena za ilustracije i sav ostali posao, a sve bi se dalo onda zgodnije urediti. Knjiga bi izišla kao nagradna knjiga, pa bi se u lipnju raspačavala. Tada se naručuje vrlo mnogo knjiga zato jer je konac škol. godine.

Molim Vas izvolite mi priopćiti jeste li s tim sporazumni, da mogu za ovu godinu 1.912. raditi na drugoj knjizi.

S osobitim poštovanjem

Josip Škavić

tajnik Hrv. ped. knjiž. zbora

Zgb. 4./10. 912.

Pantovčak 42.

Arhiv obitelji Brlić, kutija inv. br. 78, svežnjić 33.

${ }^{12}$ Ivana Brlić-Mažuranić piše Josipu Škaviću. 


\section{$25 / 9$ gis Bodn. S}

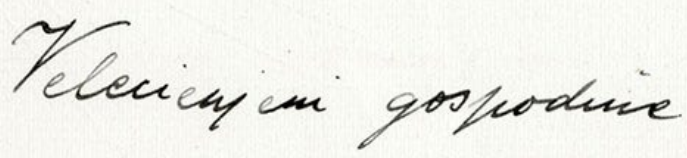

lasè cienjens fismo fisinila sam, te ls mi bilo drage da yor "stame moin fryorient us navedure nite. Tediver mi le stavlini sol minto he Uratad, posto in do 6. histoprade litis olvtesillime islari zapnicienaldastarin ficanje.

Ath se datlle ncelosi en durtremin. vilit to ls mi bilo ugodus da ee zolls

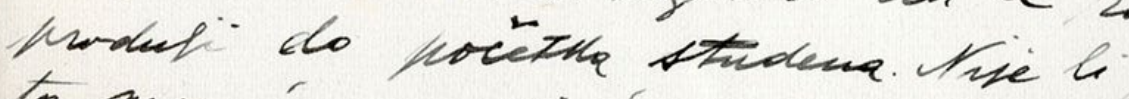
to mergucé morsti cé se stras osta vano

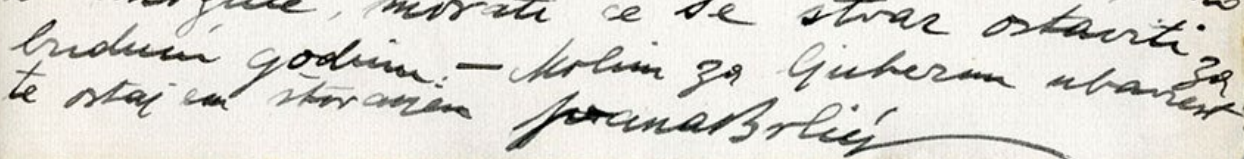

S1. 2. Faksimil pisma Josipu Škaviću od 25. rujna 1912. (HŠM A 1081 Škavić, Josip)

Fig. 2 Facsimile of a letter to Josip Škavić written on 25 September 1912. 


\section{Telenemien gospeodure.'}

Dito mi je osolito nurge stalo do toya der mopi fripozient "Gindusa vate spode Segrta Xlapica" hude tintas joi ove godine za bojic, to eam be frounila sa poshere, te le ista jiser dovssina. Sada se nalari n urepin te ju movite za 8 dana imati. $O_{m}$

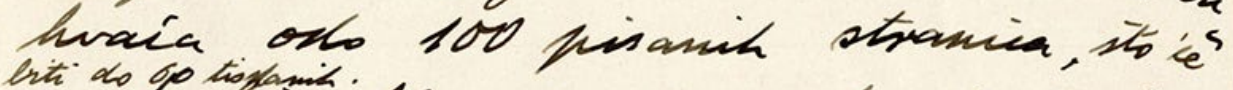
eiti do Go tioglamin. Nas da mi odmath javite mosite $l$ in usstiti medin oryocksizi

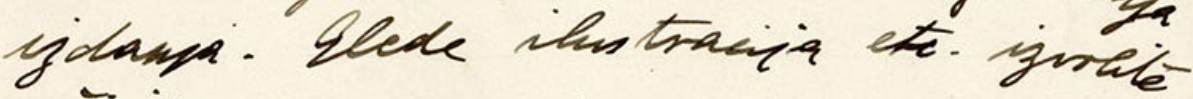
vinite prens mojem from fismen. Coolstian itsvarien

Brod na tan: $14 / 10$ giz.
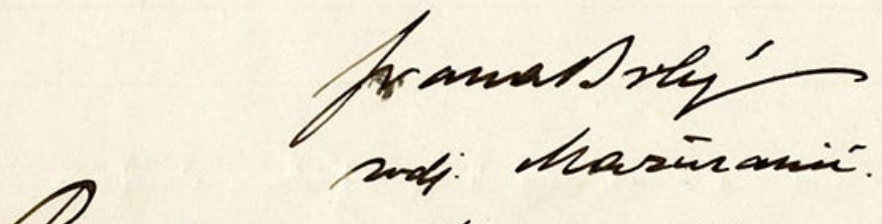


\section{4. listopada 1912 .}

\section{Velecienjeni gospodine!}

Pošto mi je osobito mnogo stalo do toga da moja pripov[i]jest: „Čudnovate zgode šegrta Hlapića“ bude tiskana još ove godine za božić[sic], to sam se požurila sa poslom, te je ista jučer dovršena. Sada se nalazi u prepisu te ju možete za 8 dana imati. Obuhvaća oko 100 pisanih stranica, što će biti do 60 tiskanih.

Molim Vas da mi odmah javite možete li ju uvrstiti medju ovogodišnja izdanja. Glede ilustracija etc. izvolite učiniti prema mojem prvom pismu.

Osobitim štovanjem

Ivana Brlić

rodj. Mažuranić.

Brod na Savi. 14/10 912.

HŠM A 1081 Škavić, Josip

16. listopada 1912.

Vrlo ugledna gospođo!

$\mathrm{Na}$ Vaše cijenj. pismo od 14./10. o. g. čast mi je odgovoriti, da držim, da bi mnogo bolje bilo, kada biste pristali, da se Vaša knjiga izda kao nagradna knjiga u svibnju 1.913. Do toga vremena dala bi se knjiga bolje urediti, slikar bi imao više vremena za izrađivanje slika i t. d. Odlučeno je, da se izdadu dvije knjige; jedna za članove, a druga kao nagradna knjiga. Zbirka ruskih pripovijedaka za mladež bila bi mnogo zgodnija za članove, jer bi je mogli i odrasli čitati, a Vaša bi knjiga opet mnogo bolje došla kao nagradna knjiga, koju dobivaju isključivo djeca u ruke. I to je jedan razlog, s kojega bi zgodnije bilo, da se Vaša knjiga izda u svibnju 1.913.

Ja sam Vam odgovorio na Vaše pismo od 25. 9., u kojem ste naveli, da u slučaju, ne može li „Zbor“ do konca studenoga na rukopis čekati, može Vaša knjiga izaći i iduće godine. U ovomu sam pismu spomenuo, da će se s izdanjem Vaše knjige pričekati do iduće godine. Budući da na to svoje pismo nijesam primio nikakva odgovora, a ni rukopis, držao sam, da ste i Vi s tim sporazumni. Pa sam počeo priređivati rukopis ruskih pripovijedaka za štampanje, a dao sam već i chlischeje praviti.

Izvolite, kako ste u pismu od 14./10. naveli, poslati mi rukopis, pa ćemo početi raditi, jer dok se taj sav posao dovrši (slike, chlischei i t. d.) treba i onako dosta vremena, pa bi onda vrlo teško mogla knjiga do Božića, kako Vi želite, biti gotova. Molim Vas lijepo, izvolite mi priopćiti, jeste li sporazumni s tim.

S osobitim poštovanjem

Josip Škavić 
Zgb. $16 / 101912$.

Pantovčak 42.

P.S. Molim Vas, biste li mi mogli kakvu zgodnu pjesmicu ili priču poslati za „Smilje“. Bio bih Vam za to vrlo zahvalan. „Smilje“ i honorira rad, ako i ne baš bogato.

Preporučujem se

s poštovanjem

Škavić

Arhiv obitelji Brlić, kutija inv. br. 78, svežnjić 33.

19. listopada 1912.

Velecienjeni gospodine!

Pristajem na Vaš cienjeni predlog od 16. o. mj. da se moja pripoviest „Čudnovate zgode šegrta Hlapića“ tiska tek u ljeto g. 1913. Pristajem na to s razloga što vidim da je taj razpored za zbor podesniji. Rukopis ću Vam priposlati, nu pošto sada neima nikakove žurbe, to ću ga još jedanput u cielosti pročitati i izpraviti.

Ujedno primjećujem da na daljnju odgodu nebih nikako mogla pristati. Ako dakle bude ikakve zaprieke da sbor i u ljetu 913. nebi mogao tiskati moju pripoviest, to molim da budete tako ljubezni te mi rukopis vratite.

Što se Vašeg upita glede „Smilja“ tiče to mi je vrlo žao što neimam ništa podesnog da Vam pripošaljem, jer sam jednu malu zbirku pripov[i]jedaka već sama izdala, a novih neimam.

Osobitim štovanjem

Ivana Brlić

Brod n. S. 19/10 912.

HŠM A 1081 Škavić, Josip 


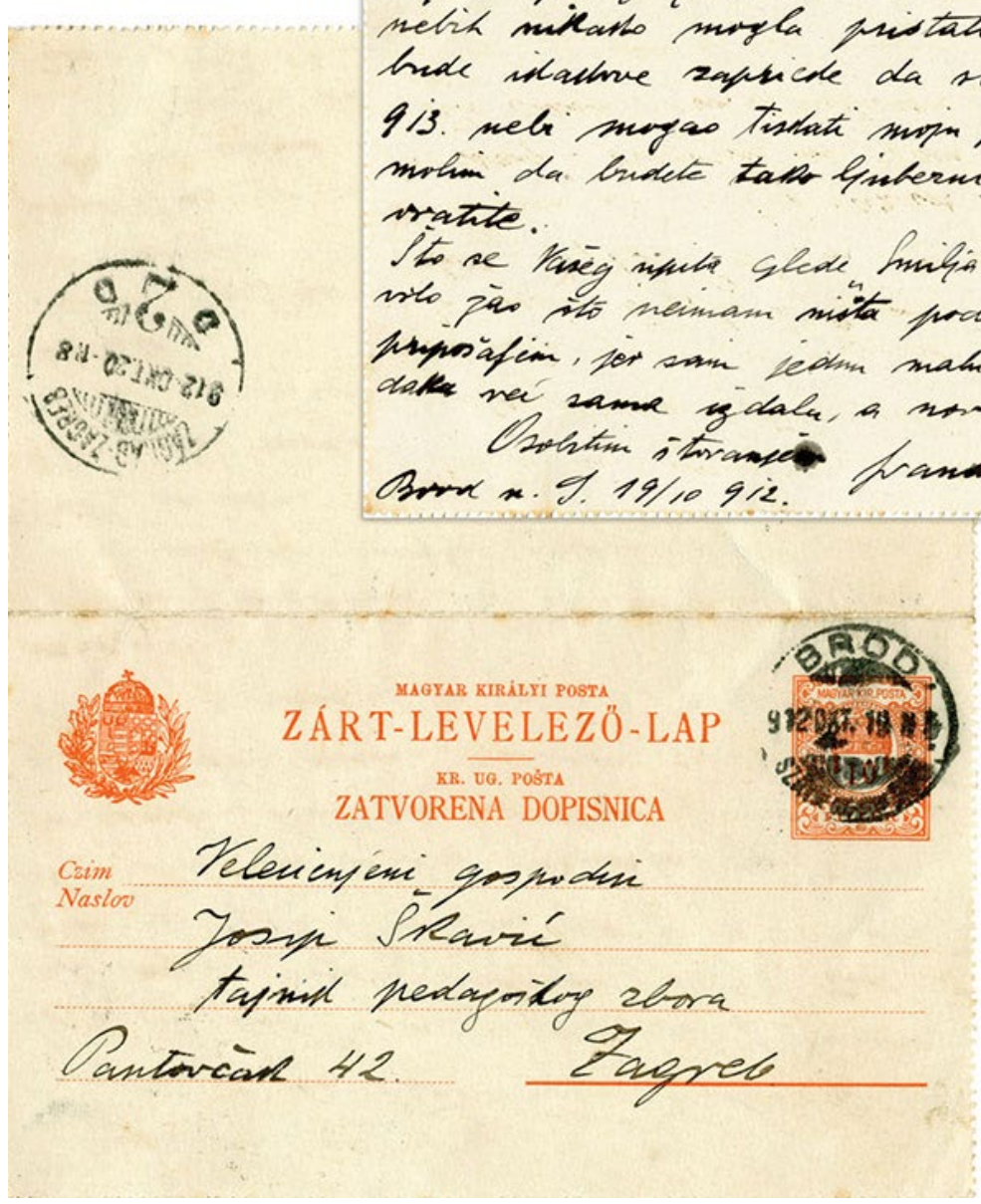

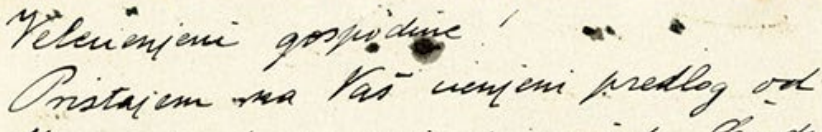
16. o. mi. da se mivia frifunest "Qsudur vate spode segrta Heleiver "Tisha terk n qitt g. 1913. Pristipen ma to s rasloge sto vidion da ie ta raxpred za ztor podesmin: Ruthopis in Mave finjoslati, sue froths sada neima milartare ginste, to in ga jo' jedanat $n$ veloste procitati i ieforarts:

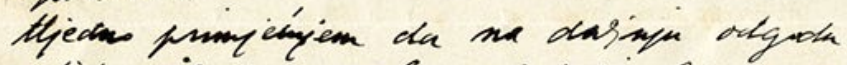

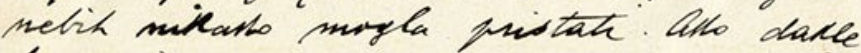

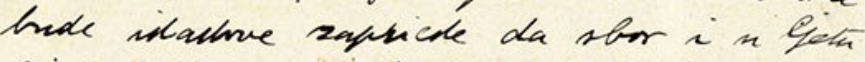
913. nels surgas tistate mipin fininesest, to molim da budete tain linberni te mi sulesing sratite.

it atie. - t t wo a ver sto neimam mista froderny des tane

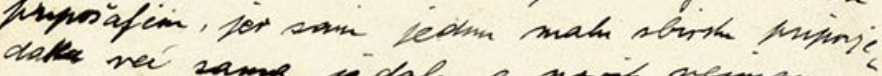

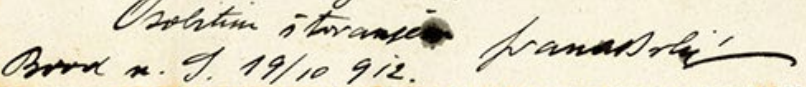

Sl. 4. Faksimili zatvorene dopisnice s pismom Josipu Škaviću od 19. listopada 1912. (Hঙ̌M A 1081 Škavić, Josip)

Fig. 4 Facsimiles of a combination letter and envelope written and sent to Josip Škavić on 19 October 1912. 


\section{5. studenoga 1912.}

Velecienjeni gospodine!

Prigodom mog boravka u Zagrebu prije nekoliko dana, potražila sam Vas u učiteljskom domu, nu nisam Vas našla. Isto tako se nije nitko ozvao na moje telefonsko zvonenje u učiteljski dom - te Vam s toga pismeno saobćujem da sam u pogledu ilustracija moje pripoviesti razgovarala sa našom poznatom slikaricom gdjom. Rojc-Šenoa. Dakako da š njom nisam mogla ništa ugovoriti, nu ona mi je rekla da bi eventualno bila spremna odazvati se ako bi joj pedagoški sbor taj posao (naime ilustraciju moje pripov[i]jedke) ponudio. Glede uvjeta etc. nisam š njome ništa govorila, samo sam joj navela da bi se imalo izvesti 10 slika. Bilo bi mi vrlo drago kad bi se pedagoški sbor mogao sa gdjom. Rojc-Šenoa sporazumiti glede tog posla, jer bih onda bila sigurna da će ilustracije biti kako si ih zamišljam. Molim Vas s toga da uzmete u obzir ovaj moj gornji pr[ij]edlog - te, ako se ne kosi sa interesima sbora, da gdji. Rojc prepustite taj posao.

Ako imade još vremena 14 dana dati ću moj rukopis ponovno prepisati, pošto sam ga prigodom opetovane korekture dosta izkrižala. Ako je pako stvar za vas već sada hitna, izvolite mi javiti te ću vam ga poslati kakav jest.

Osobitim štovanjem

Ivana Brlić

Brod na Savi. 5/11 912.

HŠM A 1081 Škavić, Josip

14. studenoga 1912.

\section{4/11 912. Draga moja mamice!}

Ja sam sada tako obuzeta šivanjem, pošiljkama i korespondencijom da se već sama sebi činim kao verfluchter Leporello [prokleti Leporello]. Nu nadam se da će za nekoliko dana biti taj odsjek obiteljskih posala gotov. Onda ćemo valjda pogotovo sasvim utonuti u novine i karte balkanske. Znaš da me već Naca u brigu stavlja, jer se odviše uživio i udubio u tu stvar. Po noći sanja o njoj, po danu čita upravo bezbrojne viesti i novine - razgovara sam sa sobom o tim stvarima od samog neizcrpivog oduševljenja s jedne strane a „rage“ [bijes, srdžba] s druge strane. Znaš kako je on vanredno nagal - a dakako da svi ovdašnji Germani i Židovi nisu mogli postati tako dobri patriote wie der Südslave aus Koburg [poput onog Južnog Slavena iz Koburga] - a Naca je odma spreman svakoga „pojesti htjeti““ koji nemisli kao mi. Moje lično pouzdanje vanredno se je diglo odkad sam u „Pressi“ čitala le Maistrovo mnienje o uztrajnosti slavenskih ideja. Ja sam si doduše to mislila odkad sam vidila da si je Željko ipak onu limonadu načinio - ali drago mi je da to i objektivci opažaju. 


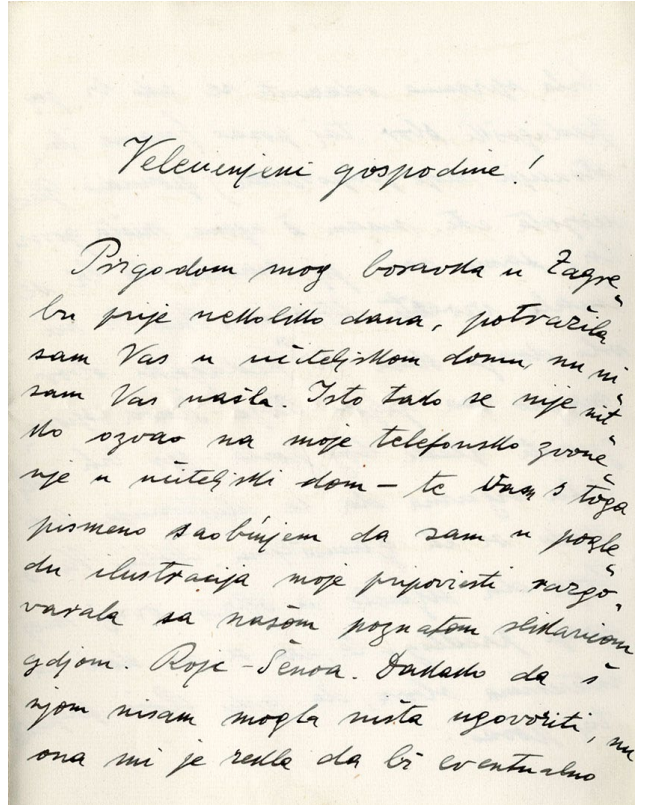

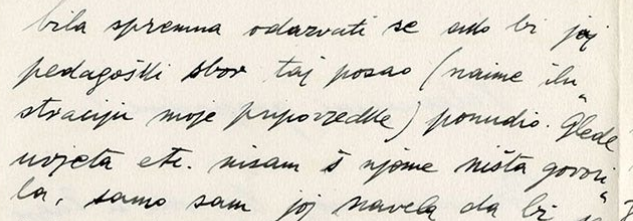
Alto uniade ion rremena 14 dana clath in niy sustopis jonorso frefign

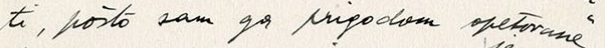
trunture dosto irevisata. Mte frado in vas vei sads hitina yovale mi invala viveste 10 slita. Silo $l_{2}$ mi who drage Had bi hedapenti Nor mogas sa gdion. Aric-Senoa troxa jumiti qlede toy fosla, ies bih? bila sigusur da ce ilustracije lite. Hado $n$ ih zamistiam. Holin tas. tryes da upmete 4 obrix ors. mo gosai uredlog-te, ano de ne hoxi iq

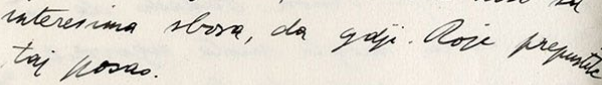
th te in vam ga poslate Haslar firs? Orolitim Atrranim

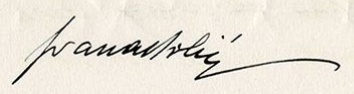
Bond no San: Sili gliz.

Sl. 5. Faksimili pisma Josipu Škaviću od 5. studenoga 1912. (Hঙ̌M A 1081 Škavić, Josip)

Fig. 5 Facsimiles of a letter to Josip Škavić written on 5 November 1912. 
Medjutim se ja vraćam na one dane wo sich groß und klein soll freuen [kada bi se i veliki i mali trebali veseliti]. Pogledala sam naime Nacinu dozu za cigarette. Ta je u miserabilnom i nepopravivom stanju. Molimo dakle staru mamu da po svojem prvobitnom planu uzme Ivi za božić jednu „,igarettendose“ - a lanac molim na moj račun dati adaptirati. Kao što vidiš spremaju se für große und klein [za velike i male] s moje strane Kleine Geschenke [mali pokloni].- Ali zato dajem iz moje privat schatulle [privatne škrinjice] $50 \mathrm{~K}$. za Bugare i Srbe, kojima to doduše neće pomoći kod zauzeća Carigrada, ali meni će se zato ipak činiti da onda imam pravo da hodam sa procesijama po Kosovom polju i da se veselim što je došao Vidov danak junački sastanak.

Vaš šah nije ovdje i neznam koje bi me exabruptno [iznenadno] pitanje na svietu više bilo moglo začuditi nego ovo! Kakav šah? Zašto šah? Odkuda šah? Neimaš pojma kako se veselim na Ristinu sliku - samo neznam hoću li ju viditi! Dakako da neću! Niste zaboravili da bude okvir okrugao? Samo ideja: bielo u bielo, ipak mi se malo riskirana čini. Da to nebi izgledalo kao crveno more i Izraelci od Petrice Kerempuha? Crveno se vidi a Izraelci ne. Ovo se naravno Nasti nebi ufala reći, već radi Hlapića ne.

Piše mi Drechsler da za buduću godinu pripravlja študiju o Ivanu Mažuraniću te da će imati tako prilike da se osvrne i na moje pjesme. Moram Ti reći da mi to nekako nije pravo. Moje su stvari sbilja tako moji privatni izljevi, da se o njima doduše može govoriti u našoj sadašnjoj literaturi, ali mi se nekako čini kao umanjivanje osobe starog tate da se mene spominje u študiji o njemu. Ja mislim da je to taktfehler [netaktičnost] od Drechslera - nadajmo se da će biti samo dvie tri linije dug. U ostalom, pisati će on tu studiju, kako javlja, istom na godinu - dakle eine jener slavischen Ideen die unter den Festungen lange verschaart liegen [jedna od onih slavenskih ideja koje dugo leže zakopane ispod utvrda].

Pišem ujedno Ivi i Nadi. Cica mi o njima donosi dobre viesti. Za Jokuša veli da je tako velika i tako gospojica da se sbilja moram čuditi tko ju je zacopral za 8 dana odkad ju nisam vidila?

Piši mi opet mamice. Ja se tako veselim kad tvoje, sada opet tako liepo i čisto pismo čitam, kao da mi je svakiput[sic] tko petaču dao. A barem se nemoram sramiti kao kod petačah. Svakom pokazujem pismo - superla koft!- Ljubim ruke tati i Tebi Ivana

Arhiv obitelji Brlić, kutija inv. br. 70, svežnjić 15. 
Libri \& Liberi $・ 2013 \cdot 2$ (2): 269-356

293

Televienjeni gospardine.'

Lanas sam odaslale na vassi: adhean pordquni prepir moje fric

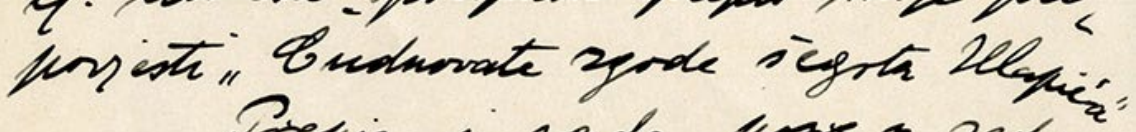
Prefin ie sada fiowe neda. pregledan i toins izquarfin. Isama priforzest irradila san fourres i toino, to mosan frinietite da sim Hrenture frawpisa, webk mogls nilladrve Mreinate, na mi najimanjé, odolont, nite na min Miotati.

Hnajte dobrotu te mi samo sn nemalis

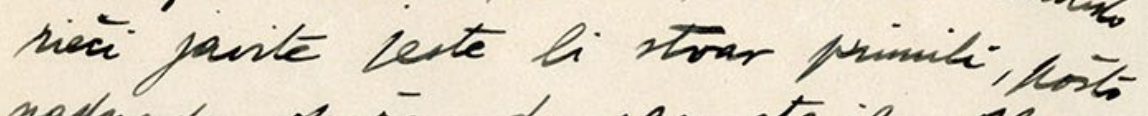
naducudres prasaim da sam stavila Rls. 40 umichto 42 .

Orobitim itwraniem thelmi recumo za waraint ieli se har olrutio na gomi.
gie?

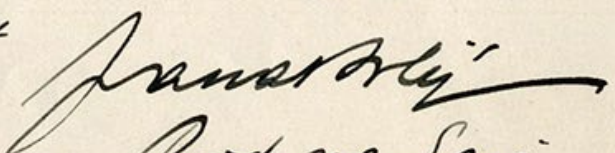
Brod na San: $28 / 119 / 2$

SI. 6. Faksimil pisma Josipu Škaviću od 28. studenoga 1912. (HŠM A 1081 Škavić, Josip)

Fig. 6 Facsimile of a letter to Josip Škavić written on 28 November 1912. 


\section{8. studenoga 1912.}

Velecienjeni gospodine!

Danas sam odaslala na Vašu cj. adresu podpuni prepis moje pripov[i]jesti „Čudnovate zgode šegrta Hlapića“

Prepis je sada posve u redu, pregledan i točno izpravljen. I samu pripov[i]jest izradila sam ponovno i točno, te moram prim[i]jetiti da osim korekture pravopisa, nebih mogla nikakove preinake, pa ni najmanje, odobriti, niti na nju pristati.

Imajte dobrotu te mi samo sa nekoliko rieči javite jeste li stvar primili, pošto naknadno opažam da sam stavila kbr. 40 umjesto 42.

Osobitim štovanjem

Ivana Brlić

Brod na Savi

28/11 912

Molim ujedno za ubavjest[sic] jeli se zbor obratio na gdju. Rojc glede ilustracije?

HŠM A 1081 Škavić, Josip

\section{2. prosinca 1912.}

Vrlo ugledna gospođo!

Primio sam rukopis „Čudnovate zgode šegrta Hlapića“ u potpunom redu. Nijesam Vam dosada toga javio, jer sam bio dulje vremena bolestan, a za vrijeme bolesti nagomilao mi se posao, koji je trebalo, što prije u red dovesti.

Sa slikaricom gđom Rojc nije „Zbor“ još dosad pregovarao glede slika za Vašu knjigu. Za vrijeme božićnih praznika doći će i to na red.

Što god će se glede Vaše knjige preuzeti, javit ću Vam odmah i točno.

S najvećim poštovanjem

Josip Škavić

tajnik ,Zbora“

Zgb. 12/XII. 912.

Arhiv obitelji Brlić, kutija inv. br. 78, svežnjić 33.

14. siječnja 1913.

Velecienjeni gospodine!

Predpostavljam da je rukopis „Zgode šegrta Hlapića“ još kod Vas, te vas molim da mi predgovor (isti se može lahko izvaditi iz rukopisa pošto je samo na jednoj strani sadržan) pošaljete, radi nekih preinaka koje mi se čine nuždne. 


\section{Teleciempeni gospurdine.'}

Predpostarliane da ie sudopies" Gorde

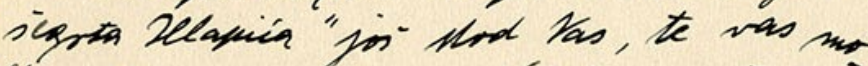
lim da mi predpovor / iste se more laciñ

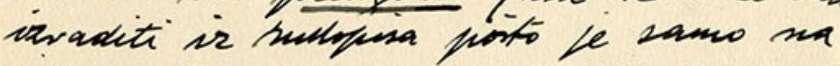
sedui Trani sadrian/ posalote, kadi netih frreinata tloje mi se cine murdne. Heidus nfugraram da hi se noor

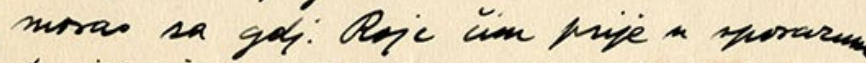
Narit, ier n sluiain da ma i fusime

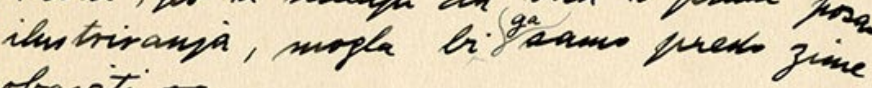
raniti

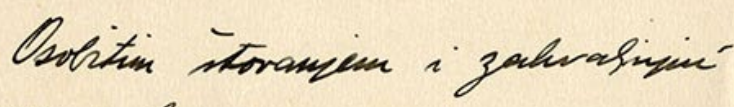
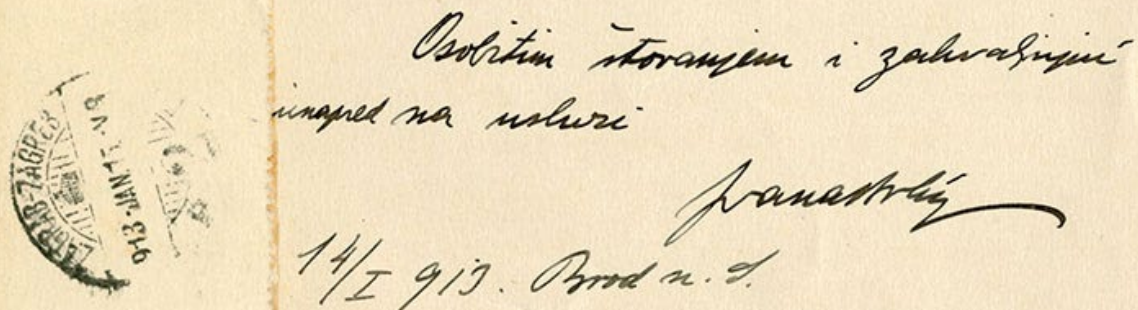
ungued na uslure.
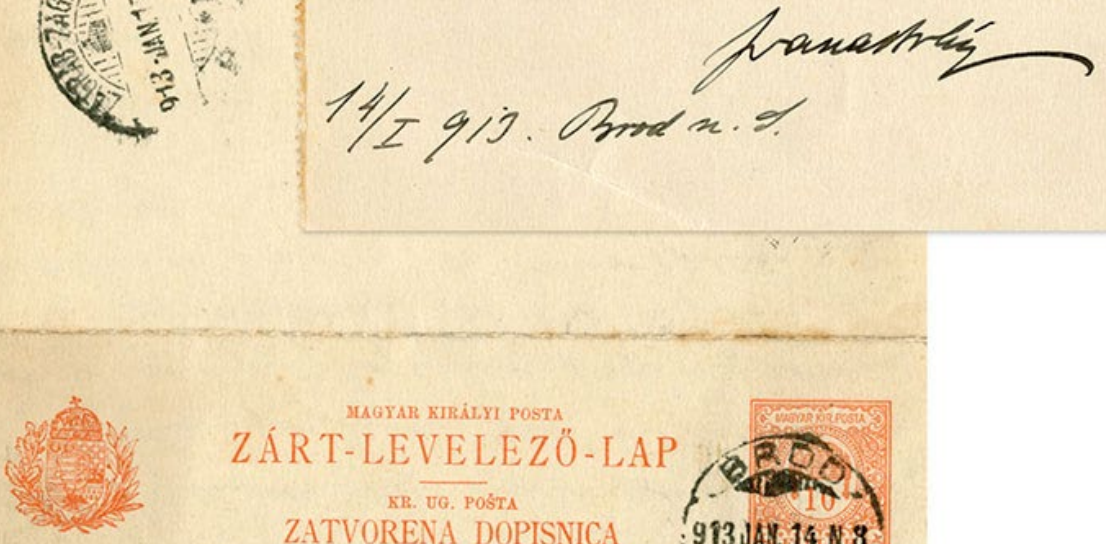

\section{ZÁRT-LEVELEZÖ-LAP}

KR. তG. POSTA ZATVORENA DOPISNICA

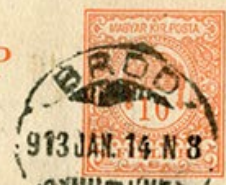

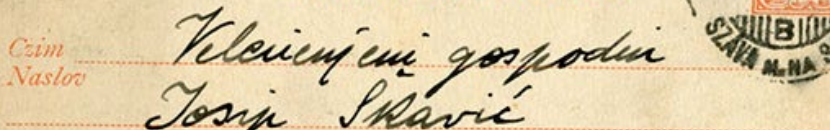

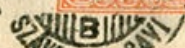

Nasloo Tosin Shavić

witel.

Pantorian 42.

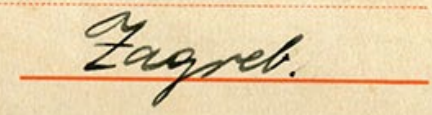

Sl. 7. Faksimili zatvorene dopisnice s pismom Josipu Škaviću od 14. siječnja 1913. (HŠM A 1081 Škavić, Josip)

Fig. 7 Facsimiles of a combination letter and envelope written and sent to Josip Škavić on 14 January 1913. 
Ujedno upozoravam da bi se sbor morao sa gdj. Rojc čim prije u sporazum staviti, jer u slučaju da ona i primi posao ilustriranja, mogla bi ga samo preko zime obaviti.

Osobitim štovanjem i zahvaljujuć unapred na usluzi

Ivana Brlić

14/I 913. Brod n. S.

HŠM: A 1081 Škavić, Josip

4. svibnja 1913.

Vrlo ugledna gospođo!

Šaljem Vam prvi arak Vaše knjige i sve slike, koje će biti u nju uvrštene. Stvarno nije ništa promijenjeno niti će se mijenjati, već samo prema dogovoru pravopis i oblik gdjekoje riječi. Vi na pr. pišete „Malim čitateljem“, što je promijenjeno u „Malim čitateljima“ $i$ druge takve sitnice, koje u samu stvar nimalo ne diraju.

Na jednome mjestu, naime ondje, gdje je Hlapić s pastirima na paši, mislim, da bi se mogao izostaviti onaj razgovor o tom da ima ljudi, koji ne vjeruju u Boga; jer držim da to baš nije potrebno da djeca znadu, a naročito ne posve malena djeca, koja polaze 1. i 2. razred pučke škole, za koju je upravo i pisana Vaša knjiga. $\underline{\text { Ja }}$ sam doduše i to netaknuto i upravo onako, kako ste Vi napisali dao složiti, no ako pristajete da se izostavi, izostavit ću.

Da Vam se šalje korektura zakasnilo bi izdanje knjige. Ja sam na vrijeme predao rukopis u štampu, no tiskara, valjda zaposlena drugim radom, nije počela slagati premda smo je glede toga i opominjali.

Molim Vas izvolite mi priopćiti Vaše opaske, da se mogu dalje ravnati.

S najvećim poštovanjem

Josip Škavić

Zgb. 4. 5. 1913.

Arhiv obitelji Brlić, kutija inv. br. 78, svežnjić 33.

\section{1. lipnja 1913.}

Brod n. S. 1/6 1913.

Draga mamice!

Već više dana neimam od vas glasa, nu nadam se da je vašoj lienosti u pisanju isti razlog kao i mojoj lienosti. Po liepom ljetnom vremenu nije čovjeku ništa tako antipatično kao pisana rieč. Nadam se da sjediš u dvorištu i da hvataš ozon, helij, radij i sve one ostale blagodati koje, po higijenskih studijah, lebde po Tvojem krasnom 
dvorištu. Je li bol u ruci jenjala? Naca sada čita neku knjigu über Schwitzbäder [o parnim kupeljima] - upravo sve se dade izliečiti š njima, misli onaj koji prodaje te aparate za znojenje. Samo neznam može li svačije srdce to podnieti? Nu moguće je da bi za Tvoju ruku dobro činili.

Imaš li viesti od Alke? Kad dolazi ona? Jeli joj jako žao što nije prisustvovala vjenčanju princese?

Kod nas teče život bez upadica, zadovoljni smo i zdravi a vinogradi nam za sada krasno stoje.

Danas činimo jedan izlet u vinograde sa familijom našeg koncipijenta Ivekovića. On i ona i tri dečka od 5 do 11 godina. Kanst dir das Leben vorstellen [Možeš si zamisliti život] danas popodne! Ti si sigurno uzkliknula u duši: ich möchte nicht dabei sein [tome ne bi htjela prisustvovati]!

Ovih dana dolazi Šaffarić po poslu ovamo i onda će biti „Stappellauf“ [porinuće] našeg čamca.- Ja se bavim dosta narodnom industrijom, ali ovo sve nije pravi način. One gospoje tamo morale bi imati više novaca ili više ,pouvoir-a“ [moći, ovlasti] da naruče veću kvantitetu stvari, kad bi želile, recimo na izložbi „Zbora“ pokazati slavonske radnje u svih njihovih formah.- Uostalom nemoj im to govoriti. Jeder soll nach seiner Art Baron werden [Svatko neka na svoj način postane barun], a od Turdovićke je svakako vrlo liepo da dalje svoj barunat upotrebljava u naše narodne svrhe, ako se i kod nas neda u velike[sic] raditi.

Neznam gdje je zakasnio moj Hlapić. Neima ga te ga neima premda su za tri nedelje izpiti i dieljenje nagrada.-

Grlim Te draga mamice i reci tati da na mojih putovanji po selu sakupljam „Wörtle“ ${ }^{\text {"13 }}$ [riječce].- Bit će to riečnik narodnih ručnih radnja oliti: „Ričoslovica der Frau Kemeter“. Tvoja Ivana.

Arhiv obitelji Brlić, kutija inv. br. 70, svežnjić 16.

28. lipnja 1913.

\section{Draga mamice!}

Jučer me je moj dečko razveselio svojom maturom. Mi smo doduše svi u našoj familiji „već takovi“ da obilujemo ovimi maturami - pa ipak je moga dečka matura dvostruko radostna, ja mislim ne samo za nas ovdje, nego i za vas tamo!- Najviše joj se veseli Zdenka. Ti neimaš pojma kako je već zadnjih dana neprestano računala u koji čas, u koliko sati etc. će Ivo stupiti u izpitnu dvoranu i kako će mu biti i neprestano je prigovarala da se mi premalo brinemo! A kad se je Ivo javio na telefon tada je počela vikati od veselja, da se je sigurno u Zagreb čulo!

${ }^{13}$ Riječ iz austrijskoga dijalekta. (op. prev. T. E.) 
Za ovu moju cielu mišpohu dolazim sada sa jednom molbom na Tebe. Mi bi rado da si nabavimo za vinograd jedan jeftini pianino. Ovaj niti je za popraviti (upitala sam) niti se može i najmanja stvar na njemu odigrati.- Prosim Te draga mamice, i[s]pitaj telefonski kod raznih glasovirnih prodaja može li se dobiti jedan sbilja dobri pianino /makar i preigrani/ za najviše $300 \mathrm{Kr}$.- Djeca imaju u svojim štednim knjižicama toliko, pak su dogovorno ove dvie male odlučile da će doprinieti tomu kupu, a sigurno će to biti najveće veselje i najveća korist u koju mogu taj novac upotriebiti.- Prosim upitaj i Željka možda i on što zna. Svakako bi za 14 dana rado da ga već imamo, jer je ljetna sezona ipak kratka, pak neka se izplati.

Kako ste zadovoljni s Hlapićem. Korektura, mjestimice jezik i interpunkcija su grozni po uputi „zbora“. Ako budeš slala Matošu piši mu prosim Te to. Kada dobijem od „zbora“ moje eksemplare poslati ću ti još tri.- Fanikinom Zvonku tako se je dopalo da je sjedio kod nas kao ukopan i čitao upravo vanrednim zanimanjem, smijehom i znatiželjom. Jedan knjižarski pomoćnik rekao je Zori (stariji čovjek) da je to tako krasno i „plemenito“ djelo, da se je on „i plakao i veselio“ i da je cielu knjigu najedanput pročitao!- To su autorski radostni trenutci, pošto je taj čovjek od onih siromaha duhom „koji su mi najmiliji“, jer su najbolji! Što javlja Alka?- O mom dolasku i Nadinom odlasku pišem sutra. Grlim Te moja mamice.

Ivana. 28/6 913.

Arhiv obitelji Brlić, kutija inv. br. 70, svežnjić 16.

12. srpnja 1913.

Zagreb 12. VII. 1913.

Draga Ivana.

Tek juće[sic] sam vidila jednu knjižicu „našeg“ Hlapića i čula sam vrlo povoljne kritike djece koja žale da ta knjiga ima kraj. Šteta što mi nije dozvoljeno bilo slobodno raditi ilustracije, bez obzira na skupoću klišeja. Malo me je ljutilo i to što si gospoda učitelji nisu zapamtili moje ime. Kako je ženi teško provesti svoj oficijelni individualitet. Da ja u privatnom životu imadem supruga to mislim, ne spada u javnost tim više što u javnom našem životu imademo, prem isto zvanje, ipak [s]kroz različiti način i shvaćanje, pa uporaba zajedničkog jednog imena dovadja do raznih konfuzija i neprilika. Čudno da me u tom ljudi ne razumiju a baš radi toga toliko na nama griješe raznim neumjestnim prispodabljanjem itd. Još uvijek je ženi teže no muškarcu postići kakovo priznanje i upravo Ti zato osobito čestitam što su se gospoda odlučila u cijeloj našoj domovini razveseliti male odlikaše Tvojom lijepom šarolikom živahnom pripovijesti „Hlapića“. Samo dalje tako, upotrijebi 
Tvoj talent na daljne[sic] veselje dobre djece i velikih. Moj muž je juće ponovno pročitao cijelog Hlapića, te smo se skoro posvadili kod tog jer sam ga i ja htjela pročitati a primjerak je od Tvoje mame a moja mama ga kani povratiti čim ga pročita. Ja sve mislim da bi Ti znala pisati lijepe priče za nas veliku djecu, moguće to potajice i činiš? Bez indiskrecije?

Za 8 dana putujem opet na more u Bašku. Kako bi to lijepo bilo da se opet nadjem s vama kao sa Nadom na Rabu, samo na dulje. Pozdravi lijepo Nadu i Tvog supruga. Tebi srdačno čestita odana Ti

\author{
Nasta. ${ }^{14}$ \\ Arhiv Odsjeka za povijest hrvatske književnosti \\ Zavoda za povijest hrvatske književnosti, kazališta i glazbe HAZU, \\ Ostavština Ivane Brlić-Mažuranić, kutija 8.
}

18. srpnja 1913.

Josipovac, 18. VII. [1913.]

Madame ${ }^{15}$,

$\mathrm{En}^{16}$ terminant la lecture du livre de Mme Votre fille, je le trouve supérieur à tous les ouvrages de notre littérature féminine: un véritable bijou.

Si le nom Mažuranić n'existait pas, le voilà crée de nouveau par les moyens littéraires. Je me félicite de pouvoir annoncer au public la naissance d'un conte à peu près classique.

En saluant respecteusement Mr Votre mari, je me recommende à Vous.

A.G. Matoš

Gospođo,

privodeći kraju čitanje knjige Vaše gospođe kćeri, mišljenja sam da je to jedan istinski biser i najbolje djelo naše ženske književnosti.

Kada ime Mažuranić ne bi postojalo, književnost Vaše kćeri iznova bi ga stvorila. Sretan sam što mogu najaviti publici rođenje ove gotovo klasične priče. Pozdravljajući Vašeg gospodina supruga, preporučujem se sa štovanjem.

\title{
A.G. Matoš
}

Arhiv Odsjeka za povijest hrvatske književnosti Zavoda za povijest hrvatske književnosti, kazališta i glazbe HAZU, Ostavština Ivane Brlić-Mažuranić: kutija 8.

\footnotetext{
${ }_{14}$ Nasta Šenoa-Rojc (1883. - 1964.), hrvatska slikarica i ilustratorica.

15 Antun Gustav Matoš piše Henrijetti Mažuranić.

16 Transkripte i prijevode s francuskoga načinila je Jasna Rebrović.
} 
31. srpnja 1913.

Vrlo ugledna gospođo!

Nadam se, da ste primili 10 primjeraka Vaše knjige.

Molim Vas izvolite napisati potvrdu za 157 kruna i 50 filira, što Vam pripada kao honorar za Vašu knjigu. Tu potvrdu izvolite poslati ili na moju adresu ili na adresu: Stjepan Horvat, blagajnik „Hrv. ped. knjiž. zbora“, Zagreb, Ilica 83., koji će Vam novac poslati, potvrda treba da glasi ovako: „Potvrda - za $157 \mathrm{~K} 50 \mathrm{f}$ /: stopedesetisedam Kruna i pedeset filira :/, što sam ih primila iz blagajnice „Hrv. pedagoško-književnoga zbora“ u ime honorara za djelo „Čudnovate zgode šegrta Hlapića“, koje je izdano kao nagradna knjiga izvan ciklusa god. 1.913. i koje opseže 5 1⁄4 štampanoga arka“ - Potpis.Štampani arak u Knjižnici za mladež plaća se naime po $30 \mathrm{~K}$, kako sam Vam to $\mathrm{i}$ onom zgodom, kad ste se o toj stvari upitali, rekao.

S najvećim poštovanjem

Josip Škavić

Zgb., 31. srpnja 1.913.

Pantovčak 42.

Arhiv obitelji Brlić, kutija inv. br. 78, svežnjić 33.

1913.

Ženska udruga za usčuvanje i promicanje narodne pučke umjetnosti i obrta Zagreb

Draga Ivana. Već se odavna spremam da ti pišem uvijek sam ali tako opterećena novim poslom za udrugu da na svoje privatne stvari moram renoncirati [odreći ih se]. Željela sam ti reči[sic] koji je utisak načinila na diecu tvoja knjiga. Marko nije više ni jeo ni spavao samo je čitao i rekao mi: Mama to je najljepša hrvatska knjiga, to je knjiga za koju se želi da neimade nikada svršetka.

Pitala sam i drugu diecu i ta se[sic] istotako[sic] ushićena i sva tvrde da još nikada nisu čitala tako krasnu knjigu. Naravski da se i roditelji zanimaju što to njihovu diecu tako začarava i sad oni i tetke i svi oni koji vole diecu čitaju Hlapića, i ja mislim da se još nikad nije jedna hrvatska knjiga toliko čitala ko što ova i bila tako obljubljena. Sad si ti pomisli kako je Branka bila sretna da je dobila direktno od tebe tu knjigu, jer ti moraš znati da si ti sad za diecu neko nadčovječje biće, i Branka nije nikako mogla pojmiti da si ti tetka od Riste, dakle od krvi i mesa. Znaš da je zbilja izvanredno kako se ti znadeš prenijeti u fantaziju i čuvstvo diece, $i$ držati ih od početka do konca u istoj visini znatiželje i veselja. Baš ti od srca hvala za te 1[i]jepe časove koje si pružila mojoj i drugoj dieci.

A sada predjimo na predmet udruge. Molimte[sic] onima rukavima „na kotače“ neka ti žene dadu još toliko od istoga platna da bude dosta za jednu bluzu. 
Ja ti se sad nemogu domisliti što sam to ono hotjela za Branku, dajmi[sic] to piši. A ako imadeš muštra od rasplita molimte da nam ih pošalješ. Šta bi se u zimi dalo još raditi izim kepčija? Znaš ja se nadam da ću još ovog mjeseca na 2-3 dana s Robertom u Brod. On imade naime jedan veliki posao za Sarajevo koji će se u Brodu premetnuti u bosanski vagon. Da mu se tu nebi štogod razlupalo hoće biti kod toga osobno prisutan. Naravski da ću mu se tom prilikom pridružiti, jako bih rado preći slavonska sela. Otići ćemo tad i u Vinkovce i obližnja sela. Ako bog da, vidjet ćemo se dakle doskora.

Medjutim primi zajedno s tvojima srdačne pozdrave od tvoje

Ženke. ${ }^{17}$

Arhiv Odsjeka za povijest hrvatske književnosti Zavoda za povijest hrvatske književnosti, kazališta i glazbe HAZU, Ostavština Ivane Brlić-Mažuranić, kutija 8.

15. listopada 1913.

Dozvolite, milostiva gospođo da Vam izrečem udivljenje za veoma uspjele: „Čudnovate zgode...“"za one žive, pune osjećaja opise. Jest, ,iz polja i livada došla je mudrost u knjige“. Hrvatskoj majci - spisateljici duboko se klanja $\mathrm{M}$ [nečitko slovo] Kovačić [potpis]

Karlobag 15. X. 913.

Razglednica Karlobaga iz Spomeničke knjižnice i zbirke Mažuranić-Brlić-Ružić, Villa Ružić, Rijeka

4. studenoga 1913.

Rome, ce 4. XI 13

Chère Madame,

Vous n'avez pas besoin de me remercier pour le compte-rendu, car j'ai rendu service plutôt au public qu'à Vous.

En saluant Me Brlić, je me recommande aux vos souvenirs bienvieillants.

\section{A. G. Matoš}

Draga gospođo, nije potrebno da mi zahvaljujete na mom osvrtu jer njime sam učinio uslugu javnosti a ne Vama.

Pozdravljajući gospodina Brlića, preporučujem se sa štovanjem.

\section{A. G. Matoš}

Arhiv obitelji Brlić, kutija inv. br. 78, svežnjić 33.

${ }_{17}$ Ženka Frangeš, rođ. Kopač, supruga kipara Roberta Frangeša-Mihanovića. 
10. svibnja 1914.

Brod n. S. 10/5. 1914.

Draga Mamice!

Danas je imao biti nedeljni izlet $\mathrm{u}$ selo Zdence, ali nam nedade barometar. Zato biram kao Sonntagsvergnügen [nedjeljnu zabavu] da Tebi, draga mama, pišem.- Pitaš kako stoji stvar sa Srv. kućom. Meni se čini da sada jako slabo, ili bolje rekuć nikako, stoji. Naca i Dobro učinili su ponudu sa 170.000 sa meublima ${ }^{18}$ [namještajem] - a to se je štedioni učinilo previsoko i odgovorila je da nereflektira na kup kuće. Od onda stvar stoji i ostaje na tom. Naca je pisao Željku i čeka od njega odgovor - premda ja nikako nevidim što bi tu Željko mogao učiniti ili savjetovati.- Prema tomu i Naca nemisli za sada doći u Zagreb - dok se možda opet što nepokrene u toj stvari prodaje.

Za mjesec dana /10/6/ viditi[sic] ćete jednog drugog našeg putnika, a to je Zdenka. Njezina škola čini, zum Abschied [na rastanku], malo putovanje na Rieku, Trst etc. pak ide i ona. Možeš si misliti kojim žarom i radošću! Tolike pajdašice!

Naca je sada 8 dana držao drotastu ogradu oko vinograda da kokoši neidu u tudje vinograde. Ja sam sad konstatirala da naš vinograd time postaje u obće kokošinjac i sad se već negovori: „idemo u vinograd“, „stanujemo u vinogradu“ nego: „,idemo u kokošinac“, „ljetujemo u kokošincu“. Najbolje je kod ciele stvari, da je Naca lani, sve bez ograde, imao 7 kvočkah sa 90 pilića - ove godine, kad je načinio ogradu od 150 metara, ima 1 kvočku sa 3 pileta! Na godinu će valjda uobće: „zaželiti ograda pilića, al pilića više biti neće!“.--

Vraćam Ti listove al fotografije još malo pridržajem. Imam puno kontaša koji to vole gledati, a još nisu vidili. Kad budu opet pisali, pošalji mi pisma prosim Te.

Imam za tatu dva wörtla [riječce] i dva prezimena. Neznam hoće li mu valjati, ali molim Te predaj mu ceduljku. Ričoslovicu sve pomalo čitam i crpem iz nje mnogo znanja za moj literarni rad, koji doduše jako zapinje na drugim poslovima i brigama, al je ipak dobar passe-temps [razbibriga] koji mi je Bog dao za nedelje i svece.- Znaš da bi ja jako rado da ona Poljakuša prevede mojega Hlapića? Bog zna hoće li?

Sve viesti o Nedi tako me vesele da Ti u obće reći nemogu još bi i rado znala kako stojimo temperamentno [s raspoloženjem]? Jesu li se Tvoji strahovi o druženju sa Natašom obistinili?

Piši mi puno i skoro opet, draga mama. Mene zadnje vrieme opet mnogo vuče srdce i želja: da bi mogla uviek biti negdje bliže Tebi. To je zaista nakon 22 godine znak velike uztrajnosti u željama. Ali što ćeš kad bez mame /i u ovoj zreloj

\footnotetext{
${ }_{18}$ Vjerojatno od Möbel. (op. prev. T. E.)
} 
dobi/ sbilja neima pravog veselja, a po gotovo[sic] neima nigdje bezbrižnosti nego kod mame! - A kad govorimo o „zreloj dobi“, moram Ti reći da sam ovih dana slučajno posudila bicikl pak sam Ti se biciklirala kao fićifal, premda već godinama nisam bila na biciklu.- To Ti čini Savski luft [zrak]! - Samo Ti mamice, nemoj sad u proljeće po varaždinski sjediti u sobi. Budi celi dan vani na vašem divnom dvorišću. Neima mjesta!

Ljubi ruke puno put!

Ivana.

Arhiv obitelji Brlić, kutija inv. br. 103, svežnjić 1 .

16. lipnja 1914.

MATICA HRVATSKA

- ZAGREB-

Zagreb, 16/VI. 1914.

Milostiva gospodjo!

Moj znanac iz Praga, gosp. Jan Hudec (Krakovská ul. 6) javlja mi, da je zet njegov, prof. Josef Filouš lijepo preveo Vašu knjigu „Čudnovate zgode šegrta Hlapića“ (Zgb. 1913.). Kako mu je Vaša adresa nepoznata, obratio se gosp. Hudec na me, da Vas u njegovo ime zamolim za autorizaciju, da knjigu[sic] uzmogne odmah ući u štampu. Ja odlazim prekosutra iz Zagreba, pa bi najbolje bilo, da saopćite izravno g. H., da dopuštate štampanje prijevoda.

Gosp. H. je preveo Dubrovačku trilogiju, Gorski vijenac, Propali dvori i druga naša važna djela, i njegovi su prijevodi zaista uzorni, te sam uvjeren, da će biti takav prijevod i njegova zeta, koji je duže vremena boravio u Hrvatskoj.

S odličnim štovanjem

Dr. Branko Drechsler ${ }^{19}$

Arhiv obitelji Brlić, kutija inv. br. 78, svežnjić 33.

svibnja 1916.

Topusko, V. 1916.

Moja draga Zorice!

Dobila sam veliko povjerenje u poštu, jer je moja upitna karta tako brzo stigla - zato šaljem ovu kartu Tebi. Hvala Ti na Tvom pismu po Nadi poslanomu. Meni je tako drago da si u tolikom miru moga Hlapića pročitala, a još mi je draže, da Ti je bio to užitak. Ja ga sama imam tako rado, kao kakvog pravog i živućeg derančića,

${ }^{19}$ Branko Vodnik, pravoga prezimena Drechsler, (1879. - 1926.), hrvatski književni povjesničar i kritičar. 
koji će se domala sretno opet $\mathrm{k}$ meni vratiti. A eto vidiš, to i biva n. pr. po Tvojim pismima, koja mi ga vraćaju i odrazuju onakvog kakvog si ga predstavljam!

Za sad je naš odlazak odredjen za ponedjeljak. Nu dvojim da će tako točno biti. Ema je jučer krvav broj udesila i odma je ekspedirana. Dolazi naša stara Marija za naše odsutnosti.-

Grli Te, srdce moje

Mama.

Arhiv obitelji Brlić, kutija inv. br. 102, svežnjić 1 .

14. studenoga 1921.

Zagreb dne 14./XI.1.921.

KNJIŽARI L. HARTMANA

ST. KUGLI

Zagreb

Prodajem Vam u Vaše isključivo vlastništvo knjigu Ivana Brlić-Mažuranić, Čudnovate zgode šegrta Hlapića u nakladi od

ne više nego 10.000/desethiljada/ eksemplara.

U ime honorara plaćat ćete mi svotu od

15.000.--/petnaesthiljada kruna/

Knjiga će izaći u ukusnoj opremi i sa ilustracijama

Kirina

Ustanovljenje cijene prepušta se Vama, isto tako i način prodaje.-

Autorica dobiva

25 dužnostnih primjeraka sa ilustracijama.-

Obvezujem se dati Vama opciju na sljedeće novo izdanje. Isto tako se obvezujem u nijednom slučaju štampati ili dati dozvolu za štampanje ćirilicom ili latinicom ovu knjigu direktno ili indirektno tako dugo, dok zaliha Vaših knjiga t. j. ovog izdanja traje.-

Arhiv obitelji Brlić, kutija inv. br. 79, svežnjić 1.

26. studenoga 1921.

dne 26. studena 1921.

KNJIŽARI L. HARTMANA ST. KUGLI

Zagreb.

Potvrdjujući primitak Vašeg cijenjenog pisma 14. XI. 1921. u stvari Nakladnog ugovora glede izdanja knjige Ivane Brlić-Mažuranić : Čudnovate zgode šegrta 
Hlapića, čast mi je saopćiti Vam slijedeće:

Po mom sudu imao bi zadnji pasus ugovora glasiti:

„Kroz vrijeme od 3 godine od danas računajući obvezujem se, da ne ću dati nikome prava na novo izdanje ovoga djela u hrvatsko-srpskom jeziku bilo latinicom, bilo ćirilicom."

Ujedno Vas učtivo molim, da mi izvolite saopćiti, dali se medju onih po Vama navedenih 25 dužnosnih primjeraka sa ilustracijama, što ih dobiva autorica, razumiju oni dužnosni primjerci, koje se imaju predati raznim kulturnim ustanovama u smislu postojećih uredaba, te koliko se takovih primjeraka imade vlastima predati. očekujući Vaš cijenjeni odgovor bilježim

sa velešto-vanjem[sic]

M. Z. ${ }^{20}$

Arhiv obitelji Brlić, kutija inv. br. 79, svežnjić 1.

\section{8. studenoga 1921 .}

ZAGREB, dne 28./XI.1921

Veleučeni gospodine doktore ${ }^{21}$ !

Potvrdjujemo primitak cijenjenog dopisa od 26. ov. mj. te Vam javljamo, da smo sa vremenom od 3 godine računajući od 1. siječnja 1922. sporazumni.-

Gdja sestra dobije

25 besplatnih primjeraka,

dok na nas otpada dužnost podavanje primjeraka u ime cenzure Kulturnim zavodima.-

Naslovna slika je dovršena, pa ćemo započeti još ove ned[j]elje sa slogom knjige.Uslobodjujemo se još upitati, komu se imadu poslati korekture, te bilježimo veleštovanjem St. Kugli

Knjižara Kr. Sveučilišta i Jugoslavenske akademije Zagreb Arhiv obitelji Brlić, kutija inv. br. 79, svežnjić 1.

${ }^{20}$ Želimir Mažuranić (1882. - 1941.), brat Ivane Brlić-Mažuranić, zagrebački odvjetnik, ministar trgovine i industrije te predsjednik Senata Kraljevine Jugoslavije.

${ }^{21}$ Pismo je naslovljeno doktoru Želimiru Mažuraniću. 
15. prosinca 1922 .

ZAGREB, dne 15. XII. 1922.

P. n. gospodin

Dr. ŽELIMIR MAŽURANIĆ

$\underline{\text { Zagreb }}$

U prilogu šaljemo ugovoreni honorar u iznosu od

K 15.000.- /petnaest hiljada kruna/

u gotovom, za upravo izašlu knjigu : Ivana Brlić-Mažuranić : Čudnovate zgode i nezgode šegrta Hlapića.

Isto prilažemo prema ugovoru i 25 komada dužnosnih egsemplara.

Molim Vas, veleučeni gospodine doktore, da nam primitak potvrdite, te bilježimo veleštovanjem

Zlatko Kugli

Arhiv obitelji Brlić, kutija inv. br. 79, svežnjić 1.

15. prosinca 1922.

dne 15. decembra 1922.

p. n. tt.

St. Kugli

potvrdjujemo primitak od

Zagreb.

K 15.000.- /petnaest hiljada kruna/

u ime honorara, te 25 komada egsemplara izašle knjige: Čudnovate zgode i nezgode šegrta Hlapića od Ivane Brlić-Mažuranić.

sa veleštovanjem:

Arhiv obitelji Brlić, kutija inv. br. 79, svežnjić 1.

16. veljače 1925.

16/II. 1925. Brod n. S.

Dragi tata ${ }^{22}$ !

Bio je prekjučer kod mene Matasović - došao je da malo proštudira Relkovićeva pisma. Bio je dva dana za redom kod mene i radio je dosta dugo

${ }^{22}$ Vladimir Mažuranić (1845. - 1928.), otac Ivane Brlić-Mažuranić, pravnik, predsjednik Jugoslavenske akademije znanosti i umjetnosti (1918. - 1921.), sin je Ivana Mažuranića (1814. - 1890.), hrvatskoga bana, i Aleksandre Mažuranić (ca. 1820. - 1885.), sestre hrvatskoga književnika Dimitrija Demetra (1811. - 1872.), jednoga od utemeljitelja Hrvatskoga narodnoga kazališta. 
u biblioteki. Za mene je jedini praktični rezultat taj da je konstatirao da mi fale dva pisma Relkovićeva /naime po onome što je Bogdanovi[ć?] g. 1907. izdao u „Viencu“ kao Relkovićeva pisma iz Brlićeve zbirke/. To je svoj prilici izvolio Bogdanović zadržati, ako nije - a tko bi znao? - prekjučer „pofalilo“?! - U ostalom u ime božje! Kad dolazi u ruke koje se za to zanimaju i to ciene, nije mi baš žao! Tako smo i Preradovićeva pisma ,povjerili“ Kostrenčiću - pa danas imamo sami njihove prepise, koje je pokojni stric, kao nekom divinacijom, dao predhodno načiniti! - Matanović me moli da mu budući put dozvolim uvid u svežanj: bosanski fratri i biskup Baričić. Čini mi se da si mi Ti jedanput rekao da bi tu moglo izaći neliepih stvari - za to sam se prilično rezervirano glede toga držala. Matasović misli doći tek u travnju opet u Brod, pa ćemo do onda viditi.- Inače je i mene i njega vanredno veselilo pregledavanje mojih raznih zbirka i zbirčica: starih slika, fotografija - raznih ,pogleda“ na stari Zagreb, zatim zbirka slika naših gradova i ruševina - a napokon i zbirka od 250 koloriranih slika iz „modejournala“, sve iz dobe krinolina! Imam to od Kušlandice - za Matasovića prava poslastica! Veli da tako veliki broj tih slika nije nigdje vidio. Za Tvoj prinos „Narodnoj Starini“ kaže da je to nešto vanredno zanimivoga i punoga. Tuži se da ima slagare koji samo onda za njeg rade kad nemaju sa dnevnim novinama posla - pa usljed toga „Starina“ tako sporo i teško izlazi.

Primila sam „Corriere“. „Merla“ mi se svojom jednostavnošću čini jako umilno pisana. Meni godi ovakova jednostavnost, kao što mi gode pjesme gondoliera: „Santa Lucia“ i „Sotto il ponte“. U dnu duše sam ipak uvjerena, da je sve što stoji višje, neka vrst prenavljanja. Ovo dakako samo šaptom kažem! - U znaku tog primitivnog uvjerenja počela sam mojega „Hlapića“ obradjivati za pozornicu. Već dugo me je „Udruga učiteljica“ umolila za jedan dječji komad - pa mislim da im to načinim. Samo nebi rado bez mojeg impresario Željka da im to ponudim. Osjećam, da uspjeh našeg englezko-hrvatskog poduzeća više ovisi o lukavosti i o poznavanju svieta i trgovačkih trikova, nego o vriednosti mojeg pisanja - pa nebi rado Željku i sebi što zafušala i izstupom malog šmrkavca Hlapića na pozornicu, a pod mojom zastavom! Nadam se da će mi se Željko telefonom javiti pa ćemo i o tom govoriti.

Mi smo prilično zdravi - a kako nas ima ovdje sedmero na kupu, to možemo biti zadovoljni ako nikome ništa ne fali. Moja Nedjeljka na 25. o. mj. navršuje 8 godina. To je već tako velika curica, da ćeš se začuditi kad ju vidiš. Neopisivo sam željna da Ti ju jedanput dovedem, da diete opet obnovi svoje uspomene na starog tatu. Inače, kraj njene bujne fantazije svaka stvar polako dobiva oblik legende $i$ priče pa tako i stari tata.

Mi smo vinograd orezali, nakolili - krumpir, grašak i sve zelenje posadili. Što god ja pamtim toga još nije bilo polovicom veljače! Viditi ćemo kako će ispasti. 
Grlim Te, dragi moj tata, i Tvoja sam

Ivana.

Arhiv obitelji Brlić, kutija inv. br. 103, svežnjić 1.

8. ožujka 1925.

\section{Mila moja Vesnice ${ }^{23}$ !}

Brod n. S. 8/III. 1925.

Ti možda misliš da neimaš više bakice kad Ti tako riedko kada piše. Ali da znaš zato kako puno bakica na Te misli i kako se veseli na to da ćeš Ti skoro u školu! Onda ćeš Ti meni svake nedelje pisati pismo - a to će tako liepo biti! Danas Ti šaljem ovdje u pismu jednu malu curicu koja se baš tako ozbiljno drži kao Ti i koja mi se ja[ko] svidja. Ona je bila tako mala kad se je Babilonski toranj gradio /to naime Nevica tvrdi/ a sad je velika i zove se „Bakica“. Po tomu se možeš uvjeriti da ćeš i Ti /koja sad isto tako držiš glavicu mudro na hero kao mala opica [majmunica]/ jedanput, ako Bog da, zvati „Bakica“. Nije nužno da se tomu odviše veseliš, ali kad jedanput dodje, onda će Ti biti i milo i drago, pa ćeš glavu isto tako mudro naheriti na drugu stranu i biti ćeš - /pst, ovo Nada, nemoj djeci čitati/ stara, vrlo mudra opica, koja za sve blago ovog svieta nebi prodala svoje zvanje Bakice.Ovu fotografiju, drago diete nemoj metnuti u onaj album s kojim se nahitavate, makar da mamica veli da imate s tim veselje, nego ju malo bolje spravi. Možda u ormar kod Kiantića ili kod one „košarene“ lopte?

Nevica Te jako liepo pozdravlja. Ona je sad iznenada postala izvrsna učenica, samo se odviše marljivo zalieva sa tintom, tako da svi bieli zapregi imaju točke, zviezde, kugle i debele pruge od tinte.- Sad uči za jednu školsku predstavu - samo nezna pjevati pa će pjesmu „Napred zastava slave“ morati valjda na harmoniki svirati ili će na ramenu donesti crnoga kosa koji će korz[sic] svoj žuti kljun fućkati, a Nevica će samo usta otvarati. Hoće li to liepo biti to neznam.

Molim Te reci Gjokici da prodajemo Lisca. Možda bi on bio kupac? Ja bi ga dosta jeftino dala, jer kažu da ima butrave noge, da je plentav, da je gmiljo i da mu treba sto kandžija do Aleske ćuprije. No sad ako se Gjoko odluči da iz svoje knjižnice digne dvie banke, ja bi mu ga dala - ali dakako bez Stipe. Jer Stipu trebam da mi drugoga konja opet dresira da bude „gmiljo“. Piši mi o tom.

Reci Tvojoj mamici da sam danas i drugo njezino pismo primila i da mu se silno veselim. Kad sakupim više poslati ću starome tati.

Mislite li vi na vinograd? Jučer su Alkica, Vukac i Nevica donieli toliko ljubica, jaglaca, visibaba i mandulinih cvatućih grančica da nismo znali kuda sa svim tim.

${ }^{23}$ Vesna Draxler, rođ. Ružić (1918. - 2012.), kći Nade i Viktora Ružića, unuka Ivane Brlić-Mažuranić. (Podatke je dao Theodor de Canziani Jakšić) 
A danas je bio imendan od strine Fanike pak smo odnieli cvieće njoj, a za to smo dobili nekoji „toboš-tortu“24 a nekoji ,fleišpittu“ [mesnu pitu].-

Zagrli Eticu i malog Hlapića-Vikića. Hlapića će predstavljati na zagrebačkom kazalištu djeca. Onda moraš i Ti doći.

Pozdrav svima a najviše mojoj Vesnici od

Bakice.

Arhiv obitelji Brlić, kutija inv. br. 101, svežnjić 2 .

20. ožujka 1925.

20/III. 1925. Brod n. S.

Dragi moj tata!

Ovaj put mi je Tvoja pošiljka „Corriera“ osobito veselje učinila. Desilo se je baš tako da nisam imala u večer nikakvog posla - /što vrlo riedko biva u mojem sadanjem samostalnom životu!/ pa sam cielu večer čitala i pročitala sve članke i člančiće. Dakako da me najviše interesira Selma Lagerlöf i dramatizacija njenog Göste Borlinga. Ja sam proglasila da će to nedvojbeno postati „Hlapić-drama“. Naime: jedan red doživljaja i pripov[i]jedčica, bez unutarnje dramatske radnje kao što se i ja, u svom djetskom genre-u borim kod Hlapića i sa istom pogrješkom! - Berlinska glomaznost opisana je tako istinski unutarnjim superioritetom da sam uživala! Tako bi se hitro i mudro zeleno zamorče rugalo devi, kad bi ona pokušala oponašati njegove „tours d'adresse“ [trikove, vještine]! Osobito me zanima već od početka stvar one Poljakinje koja je, iz milosrdja, ubila svojega muža. Kako duboko i kako izpravno, a sa malo rieči žigoše pisac moderno milosrdje i moderno degeneriranje zakona! Škoda da je sve to u Mussolinijevoj domovini izgubljeni biser mudrosti.

Šaljem Ti dalje Nadin putopis iz domovine toga Mussolinija, a iz podzemlja Petrove crkve. Mussolini se u svom cielom životu sigurno nije nikada sjetio ove „loggie“ [lođe], koja tamo leži u svojoj neiskazanoj ljepoti i snazi, a sakrivena pod površinom italske zemlje - u obće pod površinom globa! Ja držim i uzdam se da tako ima i u duši čovječanstva, pod sadanjom ružnom i nakaznom površinom, jedna prekrasna, svjetla loggia sa svetištem, do koje ćemo konačno i sami stići, kad se do sita nalutamo po tamnim koridorima katakombah!

Mi smo ovdje „Dubravku“ liepo odglumili, a meni je pri svemu tomu najmilije, da je moja Nedeljka mogla čuti one krasne verze Gundulićeve, dočim joj je onaj cieli ornat, kojega su vrlo dobro udesili, pomogao da shvati i da osjeti ljepotu rieči n. pr. staroga svećenika.

\footnotetext{
${ }^{24}$ Vjerojatno je riječ o doboš-torti, prema Mađaru Dobosu koji ju je osmislio. (op. prev. T. E.)
} 
Primila sam od Matasovića iz Skoplja pismo. U pogledu naše ovdašnje realske Brlićeve knjižnice, savjetuje mi da se obratim na ministarstvo prosvjete i da se š njima sporazumim da se ta ciela knjižnica preveze u Zagrebačku sveučilišnu biblioteku. Dakako da ja to sada na nikoji način nemislim učiniti - to bi značilo spasiti knjižnicu kao što je onaj poznati medved spasio svog gospodara od muhe! Knjižnica je doduše ovdje podpuno „preisgegeben“ [prepuštena na milost i nemilost] - no kad neima načina da se direktore prisili da ju urede, onda nek barem ostatci ostataka nepadnu pod ministarske odredbe!

Mi smo hvala Bogu zdravi, a nadam se, dragi tata, da je i kod vas tako, premda nečujem od vas ništa. Samo od Riste imam pismo u kojemu „se joka“ što nemože da dobije romane Retcliffa. Vidiš, dragi tata, da ima još vrlo sretnih, vrlo dobrih i vrlo mladih ljudi na svietu! Ovo posljednje je osobito utješljivo.

Grlimo Te, mili moj tata i čuvaj se ove ljute zime, koja nas sve goni k peći. Rabi moju vunenu kapicu, koju sam Ti po Nadi poslala i koja je mene spasila od onog tromjesečnog čirića u vratu! Valjda će sad i zazeleniti vaše krasno dvorište pa ćemo i zaboraviti za zimske tegobe!

Grli Te Tvoja zahvalna

Ivana.

Arhiv obitelji Brlić, kutija inv. br. 103, svežnjić 1.

11. travnja 1930.

Paní

Ivana Brlić-Mažuranićová,

Zagreb,

Trenkova 5.

11. dubna 1930.

Vážená paní,

rádi bychom vydali Vaši knihu Podivne prŕibehy učně Kloučka v překladu prof. Josefa Filouše, s obrázky Josefa Lady.

Dovolujeme si Vám nabídnouti autorisační poplatek pro 3.300 vytisku stejny jako u Pohádek, t. j. 1.000 frs., splatnych při vydání knihy, t. j. asi v říjnu t. r. a 5 vytisků autorskych, volnych.

Doufáme, že po dobrych zkušenostech s Vašimi Pohádkami autorisační právo nám laskavě udělíte, a že nám take pro náš obrazkovy měsíčník Panorama napíšete članek o vzniku Vaší knihy a zašlete nám nejakou svou novou fotografii.

Děkujeme Vám předem a jsme

uctivě 
Vydavatelstvo družstvení práce

V Praze XII. Slezská ul. 13.

11. travnja 1930.

Veleštovana gospođo ${ }^{25}$,

željeli bismo objaviti Vašu knjigu Čudnovate zgode šegrta Kloučka u prijevodu prof. Josefa Filouša, s ilustracijama Josefa Lade.

Dopuštamo si ponuditi Vam autorski honorar za 3.300 primjeraka isto kao i za Priče, to jest 1.000 frs, naplativih po objavljivanju knjige, to jest vjerojatno u listopadu ove godine te pet besplatnih autorskih primjeraka.

Nadamo se da ćete nam, zbog dobrih iskustava s Vašim Pričama, autorska prava ljubazno prepustiti, te da ćete nam za naš ilustrirani časopis Panorama napisati članak o postanku Vaše knjige te nam poslati neku svoju novu fotografiju. Zahvaljujemo Vam unaprijed te smo s poštovanjem

Vydavatelstvo družstvení práce

U Pragu XII. Slezská ul. 13.

Arhiv obitelji Brlić, kutija inv. br. 80, svežnjić 46.

\section{3. svibnja 1930.}

Paní

Ivana Brlić-Mažuranićová,

Zagreb.

23. května 1930. [23. svibnja 1930.]

Veleštovana gospodjo, zahvaljujemo na Vaš cijenjeni list; njegov sadržaj ćemo upotrijebiti k propagaciji Vaše knjige „Čudnovate zgode šegrta Hlapića“.

Šteta, da to nije onako, kako smo si predstavljali. Mi bi rado saznali, iz kakovih impulsa je Vaša knjiga izašla.

Sigurno je Vam svijet malog šegrta stran, te bi naše čitaoce zanimalo, kako je k tome došlo, da ste napisala tako lijepu knjigu.

Mislite, molimo, da je kod Vas redaktor, koji je znatiželjan a koji Vas ispitiva o Vašoj knjigi, o svim njezinim dogadjajima a Vi da mu odgovarate.

Mi bi Vam bili vrlo zahvalni za Vašu novu sliku, jer Vaša fotografija, koju ste nam prije godine dana poslala nije za reprodukciju dosta izrazna.

Bit će nam drago, veleštovana, ispunite-li[sic] našu želju te nam pomognete približiti Vašu knjigu srcima československih čitača.

${ }^{25} \mathrm{~S}$ češkoga jezika preveo Berislav Majhut. 
Veleštovanjem odani

$\mathrm{za}$

Vydavatelstvo družstvení práce

V Praze XII. Slezská ul. 13.

[isto pismo češki nakladnik je još jednom poslao Ivani Brlić-Mažuranić 24. IX. 30.]

Arhiv obitelji Brlić, kutija inv. br. 80, svežnjić 46.

23. rujna 1930.

Paní

Ivana Brlić-Mažuranićová,

Zagreb,

Trenkova 5.

V Praze

23. záŕí 1930.

Vážená paní,

dne 23. května t. r. poslali jsme Vám chorvatský dopis, jehož opis v př́loze posíláme, na který jsme, bohužel, nedostali do dnešního dne odpovědi.

Byli bychom Vam velmi vděčni, nemůžete li nám vyhověti ve věci článku pro naši Panoramu, kdybyste nám alespoň poslala svoji novou fotografii, protože ona, kterou od Vás máme, je již poněkud zastarála.

Děkujeme Vám předem za laskavost a jsme Vám uctivě oddaní za

Vydavatelstvo družstvení práce

V Praze XII. Slezská ul. 13.

Gospođi

Ivani Brlić-Mažuranić

Zagreb,

Trenkova 5.

U Pragu

23. rujna 1930.

Veleštovana gospođo,

dana 23. svibnja ove godine poslali smo Vam hrvatsko pismo čiji prijepis šaljemo u prilogu, na koji nismo, na žalost, do danas dobili odgovor.

Bili bismo Vam jako zahvalni, ne možete li nam udovoljiti molbi što se tiče članka za našu Panoramu, da nam barem pošaljete svoju novu fotografiju, zato jer je ona koju ste nam poslali, već ponešto zastarjela. 
Zahvaljujemo Vam unaprijed za ljubaznost a Vaši smo odani

Vydavatelstvo družstvení práce

U Pragu XII. Slezská ul. 13.

Arhiv obitelji Brlić, kutija inv. br. 80, svežnjić 46.

22. siječnja 1931.

Velecijenjeni gospodine uredniče!

Prekjučer sam primila Vaše lijepo izdanje „Kloučka“ (10 exemplara). Zahvaljujem Vam za pošiljku. Izdanje je vanredno uspjelo i upravo godi oku po svojoj radosnoj vanjštini. Šaljem Vam u privoju člančić o genezi „Hlapića“. Molim da mi javite hoćete li ga i gdje ćete ga objelodaniti. Svakako: ili u cijelosti li nikako. Srdačnim pozdravom i štovanjem:

Ivana Brlić Mažuranić v. r.

Brod n. S. 22. I. 1931.

Arhiv obitelji Brlić, kutija inv. br. 80, svežnjić 60 .

22. siječnja 1931.

O postanku malog „H lapića-Kloučeka“

Jednog me je proljeća zanimao neki mali, vanredno skladni opančarski šegrt, bucmastoga i uvijek nasmijanog lica, a jasnih, čestitih i veselih očiju. Slijedila sam tijekom nekoliko nedjelja njegovo žustro poslovanje na pijaci našeg malog grada. Kad bi sa svojim drugom nosio na dugačkoj motki poredane opanke, da ih izloži pod šatorom, sklizali su opanci sve polako po motci prema malome, jer je nosio prvi kraj motke, a bio je mnogo niži od svog druga. Konačno je gotovo sav teret ležao na ledjima maloga hlapca - no on je i nadalje fićukao, a njegovo garavo, dobrano zamusano, no još više nasmijano lice nije odavalo nikakve gorčine nad ovom nepravednom podjelbom tereta.

Pošla sam jednom da vidim, kod koga taj mali titan posluje - i ugledala sam pod šatorom poslodavca: čistu opreku malome šegrtu. Surova, ružna i odmah na prvi pogled nemila vanjština - a grubi i neskladni glas, koji je bez daljnjega mogao da posluži Majstoru Mrkonji. No taj ne bijaše još niknuo u meni. Nego pomislih: čudnovate li razdiobe ljudi, ne samo na brodskoj pijaci nego i po čitavome svijetu! Zašto ovako umiljatom djetetu ovako nemili gazda? No uto mi pade na pamet narodna pripovijetka, kako su neki seljani pošli do dragoga Boga, da se potuže, što je on najbolju i najvrjedniju djevojku dosudio najljenijem i najnevaljanijem 
momku u selu. „Takovomu i treba valjana žena“ otpremi Bog seljane. - Pa valjda i ovaj mališan ima svoju svrhu uz ovog nemilog gazdu - završim za ovaj put svoje umovanje. - Medjutim se desilo, da mi je pukim slučajem bio odignut jedan mali skutić onoga zastora, kojim je život svakoga čovjeka prekriven - a po pravu pjesnika i pisca proširila sam onda i izradila sam sličicu, koja mi je u taj tren bljesnula u oči. Bilo je to ovako: Ljeti je naše divno vinogorje u blizini Broda na Savi napučeno. Svatko, tko nije već baštinio vinograd, nastoji da tamo stekne bar krpicu vinograda i bar šačicu kolibice, gdje može da od subote do ponedjeljka uživa divote našeg ljeta i naše jeseni. U samoj stvari je svijet zaista vrlo malo pokročio naprijed, te bi se naša prastara brodska „subota i nedjelja“ mogla dići na očigled Europe kao neki davni rustikalni pra-stric modernog engleskog Week-enda!

Takovu sam dakle jednu ljetnu noć provodila i ja u našem vinogorju, u svojoj kućici. Oko mog vinograda svuda poraštrkani vinogradići i kolibice-maleni posjedi, ali neiscrpivi užici naših gradjana i obrtnika. $U$ večer - tople naše i zvjezdane večeri, gdje zvijezde kao blistave škude sjaju na dubokom, svjetlom nebu! - u večer palili se krijesovi na sve strane, pjevale se svuda prastare vinogradske pjesme, ozvanjala je tamburica i orio se po gdjekoji radostan hitac iz puške. Kao da se neka svečanost slavi u ubavom brodskom vinogorju? A kad tamo: ništa! To naprosto duša našeg gradjanina - prasjedioca uživa, kao što su i pradjedovi uživali, u neopisivoj idiličnoj ljepoti ovoga kraja i u tim zaista bajoslovnim ljetnim noćima. A poslije polnoći sve utihlo. Krijesovi pred kolibicama dogorjeli, samo pokoja žeravica još tinja - u kolibicama se svjetiljke trnu, kroz širom otvorene niske prozorčiće leprša na časove šareni zastor, a unutra netko hrče - bezuslovno hrče!

Noćni pokoj! - Gdjegdje ipak šuška jež po stazici, a katkada prodre tišinu nemili krič velikog kozodoja, koji vješto križa kroz guste krošnje voćnjaka, a da se nikada ne takne krilom grančice. No u to - tko bi znao odakle? - sabrala se oluja. Oblaci grnu jedan za drugim, zvijezda za zvijezdom gasne pod tmastim gomilama, Vlašići još načas trepere kroz pukotinu u oblaku - ali eto već bljesak, tutanj, grmljavina. Začas: kiša, pravi potop! Gromovi razdiru noć na sve kraje. - Vihor njiše krošnje ogromnih oraha, koji se na mahove dotiču jedan drugoga svojim orijaškim granama kao da se rukuju u ovoj nenadanoj nedaći. U ravnim, pravilnim redovima vinograda čuje se po gdjekad pucketanje: to puca kolić pod udarcem vihra[sic], a vinov trs u mraku klone kao povaljen vojnik na tlo ili se hvata u bujnu lozu svojega susjeda, te ostaje oslonjen medju gustim lišćem, kao u zelenom zagrljaju vjernog bojnog druga. Strašno, žestoko, al kratko i kao odsječeno, dolaze i odlaze te noćne oluje - i eto - sad samo još kiša: pljušti, pljušti! potočići vode klokoću nizbrdice kroz jarčiće oko moje kuće u limenom žlijebu bubnja voda u sav glas i ruši se u staro bure kao pravi propisni vodopad, koji prebacuje svoje valove prije cilja, a klokoće, kad se 
stropošta u dubinu. Dakako u maloj vinogradskoj kućici ne možeš, a da ne slijediš sve peripetije ovakove oluje. Pomnim sam uhom slušala štropot mog vodopada no u to mi se učini, da tik uz njega čujem ljudske glasove. Otvorim kapke - voda sakupljena gore na daščici zapljusnu mi u lice, al pod prozorom tik uz moje bure ugledam neko čarobno čudo: veliki, okrugli crveni sjaj, kao neki ogromni prozirni lampion, a usred njega ni manje ni više nego upravo onaj naš nemili surovi gazda. Nedaleko njega, pod mojom strehom, te još uvijek u onom crvenom, čarobnom sjaju, klečao je na mokroj cigli, sagnut sasvim pod moje bure, mali bucmasti šegrt. Začudna ta vizija osupnu me u prvi čas, dok ne zamijetih, da crveno osvjetljenje dolazi od odsjeva ogromnog crvenog kišobrana, kojega je majstor držao razapetog, te od vinogradarskog lampaša, kojim je svijetlio malome. - „Što radite?“ upitam ne malo udivljenja[sic], premda mi je odmah bilo jasno da je nemili majstor jedan od onih mojih mnogobrojnih bližih ili daljih susjeda koje nijesam poznavala. „Eto! besposlice! Tražimo neku mačkicu.“ - „Eto je, eto“ viknu u taj čas mali i uspravi se u onom crvenom svjetlu sav sjajan od radosti. U naručju držao je najobičniju malu, šarenu mačkicu, koja je ikad izvučena ispod vinogradskog bureta! No on je stajao čupav, garav i ponosan, zavio macicu pod poderani kaputić, tako da joj je samo umna glavica sa nemirnim šiljatim ušima virila napolje. „Ne bi li bila grjehota da ovako kisne?" Govorio je mali gladeći je prstićem po sivoj njuškici dok je kiša sve polaganije i sve opreznije kuckala po crvenom kišobranu, a mrak nakon oluje bivao opet sve prozirniji. Neki odsjev mekoće pao je po nelijepom licu majstora, dok je promatrao maloga. „Našao je sinoć tu mačkicu, hoće da ju dade mojoj maloj - a kako mu je utekla kroz prozor, nije dao mira... itd.“ „Jeli vam rod taj mali?“ - „Kakav rod! Siroče! Napast! Hajdemo!“ Nekuda je meko glasio taj tobože strogi poziv. Okrenuše se i podjoše. Veliki razapeti crveni kišobran, zabačen na rame majstora, prekrio mi je i majstora i malog i šarenu mačkicu. Odlazili su kao jedna jedina cjelina, zaokruženi tajnovitim crvenim svjetlom. Odlazili su opet natrag u onaj svoj život o kojemu nisam baš ništa znala doli ove male zgodice. No osjećala sam, da ova trojica, što mi ovako tijesno spojeni iščezavaju sa vidika, nisu spojeni niti po ogromnom crvenom kišobranu niti po čarobnoj crvenoj svjetlosti. Osjećala sam, da ih je u ovu cjelinu spojila jedna na oko sitna, a u istinu nesavladiva moć: dobrota, podatnost i vedra ćud ovog siročeta, koje i samo ne zna, koliki je neizmjerni dar Bog položio u njegovo bodro srdašce.

I dok mi je crveni kišobran polako umicao[sic] sve dalje put nepoznate kolibice, dotle su - gle zaista - nekim magičnim obratom počela da mi se sa dalekog obzorja savske ravnice opet vraćaju sva trojica. Njihovi su likovi još zamagljeni, no oni idu ravno k meni te bivaju sve jasniji. I već probijaju nasmijane vedre očice i zelene hlačice šegrta (neka bude - šegrt Hlapić!) i već se orisuje kao ugljen crna brada 
majstora (neka bude - Majstor Mrkonja!). Ganuta umiljatim likom malog šegrta otvorila im je moja mašta odmah širom svoja vrata, stavila im je na raspolaganje svoje nebrojene poljane, svoje livade, svoje gradove, i radionice, svoje burne vašare i vrtoglave vrtuljke. A Majstor Mrkonja i mali Hlapić, našavši se u tolikom i tako zgodnom priboru[sic], počeli su da se i sami rasporedjuju i da se udešavaju. Bez moje daljnje saradnje izgradili su oni eto vlastoručno pripovijetku „Čudnovate zgode šegrta Hlapića“

Evo, gospodine uredniče, ovo je istinita priča o postanku knjige, koja Vas zanima. Ne bih Vam je nikad odala, da me nije Vaše zaista dražesno češko izdanje „Šegrta Hlapića“ toliko razveselilo i zadovoljilo. Vedre i tako umiljato šaljive slike i boje izmamile su ovu moju ispovijest - premda držim, da svako otkrivanje o postanku neke knjige uvijek oduzima toj knjizi mnogo od njene neposrednosti.

Konac

Brod n. S. 22/I 1931.

IBM

Arhiv obitelji Brlić, kutija inv. br. 82, svežnjić 13.

23. siječnja 1931.

Brod n. Savi 23. I. 1931.

Visokocijenjena gospođo profesor! ${ }^{26}$

Vidim, da je medju nama telepatsko općenje najefikasnije: prekjučer na večer mislila sam dulje vremena na Vas i nagadjala što to može biti, da su mi posljednjih mjeseci posve izostale one Vaše mile kartice, na koje ste me bili toliko naučili, da mi sada zaista vrlo fale. A jučer ujutro - eto Vaš[e] milo i prilično opširno, pismo. U njemu dakako i opet vrlo malo o Vama! A ja bih jednom zaista rado da mi pišete o Vašem poslovanju jer slutim baš po ovom Vašem dugom muku, da na nečem zbiljnom i važnom radite. Nadam se, da Vas i zdravlje služi i da ćete se oprijeti bujuici[sic] gripe, kojoj ja nastojim naći lijeka u energiji. Što se tiče gospodje Elge Kern zaista ne znam ni što da Vam odgovorim, ni što da joj pošaljem. Prilično sam siromašna na idejama za takove naručene članke. Nego mislila sam, da Vas umolim da pročitate moj isto tako prisilni članak o genezi „Šegrta Hlapića“. Ako bi možda taj, koji sadržaje baš neku vrst autobiografske crtice bio podesan za gospodju Kern, to nemam ništa protiv toga, da joj se pošalje. Članak sam priposlala Željku, a kako nemam drugog prepisa, to Vas molim da mi javite, želite li ga čitati i bili Vam ta ideja bila simpatična. Ja ću onda Željku pisati, da Vam ga pošalje, a Vi ćete opet meni pisati, te ću ja članak na njemački prevesti i poslati ga u Meinnheim.

${ }^{26}$ Ivana Brlić-Mažuranić piše profesorici Camilli Lucerni (1868. - 1960.), hrvatskoj filologinji i prevoditeljici. 
Iz Zagreba uopće vrlo malo čujem, jer mi se ni Alka u posljednje vrijeme ne javlja. Jedini Ivo vjerno se i redovito javlja, a nadam se, da ga i Vi kadgod vidite. Mi smo ovdje u posljednja dva mjeseca bili razvili takvu vrtoglavu djelatnost $u$ pogledu korespondence, javnog dobrotvornog rada, u pogledu javnih i kućnih priredaba i predstava, da mi zaista ne bi ni bilo moguće za sve vrijeme otići iz Broda. A dolazi tu i pitanje izdataka, koje ne malo važi. Nadam se ipak u februaru ili martu sve tako srediti, da bih mogla opet u mojoj garconijeri u Zagrebu kojih 14 dana provesti. Da pritom najvećim veseljem mislim na Vaše mile posjete, to mi možete odmah vjerovati. Srdačno Vas pozdravljam i očekujem Vaš mili odgovor: Odana Vam:

I. B. M.

Arhiv obitelji Brlić, kutija inv. br. 80, svežnjić 61.

\section{3. veljače 1931 .}

3. II. 31

Ovaj čas primila i pročitala (s Elsom Kučerom) predražesnu pričicu o postanku šegrta Hl. Predražesna - ali odviše specijalna, pretpostavl[j]a ipak manje više poznavanje knjige.

Moja bi želja bila, da u opis vinogradske idele[sic], koja bi se djelomice mogao upotrijebiti, uđe ona trojka misli, koju ste mi jednom rasvili[sic], kada smo po mjesečini sjedile na balkonu. Onaj Vaš stav prema vječnosti i onu o iščezavanju svega kad raste pronicavost oka i uha.........

O svojemu radu htjela sam Vam dati malo sliku, draga gospođo B. M., ali eto opet ne mogu! - Prevela sam: Ribar Palunko i njegova žena, sada ću prepisati druge prevode. Pisala mali članak o Melek Jaši i Caracenu, primila i pročitala mnogo knjiga i ocijenila neke, uz to na mnoga pisma i zahtjeve odgovorila, i t. d.

Nadam se ipak Vašemu dolasku pri koncu ovoga mjeseca.

Srdačno pozdravlja odana Vam

C. L. [Camilla Lucerna]

C. Lucerna

Zagreb

Grič 2

Arhiv obitelji Brlić, kutija inv. br. 80, svežnjić 61. 
5. veljače 1931 .

5. 2. 1931

Paní

Brlić-Mažuraničová, spisovatelka, Brod n. Sav.

Jugoslavija

Milostivá paní, děkujeme Vám za velmi krasný Váš článek o vzniku Vašeho Hla piča. Domníváme se, že čtenáři naší Pan or amy budou Vám za članek vděčni, stejně, jako jsou za knihu. Článek prirozeně otiskneme beze změn a nezkrácený. Máme take uprrímnou radost z toho, že se Vám kniha líbila.

Honorář poukázali jsme Československou bankou v Daruvaru a prosíme Vás o laskavou zprávu, zda jste jej již obdržela.

Se srdečnými pozdravy

uctivě oddaní

za

Vydavatelstvo družstvení práce

V Praze XII. Slezská ul. 13.

Gospođi

Brlić-Mažuranić,

spisateljica,

Brod n. Sav.

Jugoslavija

Milostiva gospođo,

zahvaljujemo Vam na vrlo lijepom članku o postanku Vašega Hlapića. Pretpostavljamo da će Vam čitatelji naše Panorame biti zahvalni za Vaš članak jednako kao što su zahvalni za knjigu. Članak ćemo naravno tiskati bez izmjena te neskraćen. Također iskreno nas raduje da Vam se knjiga svidjela.

Honorar smo doznačili Čehoslovačkoj banci u Daruvaru te Vas molimo za ljubaznu obavijest jeste li je već primili.

Sa srdačnim pozdravom

učtivo odani

Vydavatelstvo družstvení práce

U Pragu XII. Slezská ul. 13.

Arhiv obitelji Brlić, kutija inv. br. 80, svežnjić 61 . 
17. veljače 1931 .

Stara Pazova, 17. II. 1931.

Milostiva gospođo,

kad se već toliko brinete i želite da moj prijevod pospješimo, slobodna sam zamoliti Vas Vaš najnoviji prijevod „Šegrta Hlapića“, pa ću ga poslati „Matici Slovačkoj"،.

Mnogo Vam hvalim na dobroti i sjećanju.

Ljubim Vam ruke i štuje Vas odana

Dollinayová-Vračanová

Arhiv obitelji Brlić, kutija inv. br. 80, svežnjić 61.

29. lipnja 1931.

Veleštovana gospodjo!

Zahvaljujem Vama što ste mi poslali Vašu dramatizaciju Vaše pripov[i]jesti: „Šegrt Hlapićc, jerbo mi je dala priliku upoznati se bolje [s] Vašom zlatnom dušom, dušom plemenitog čovjeka, požrtvovne žene i - idealne majke. Ovaj je lik Hlapić odsjev Vašeg naziranja na svijet koji se rodio u Vašem optimizmu dajući Vam sretne iluzije za „dobro i lijepo“. To je uobće i temelj Vašem pjesničkom djelovanju.

Sretno se afirmiraste sa Vašim pričama, razkazima i pjesmama kao poetessa - da i kao pedagok[sic]. Sa dramatizacijom Hlapića ulazite u polje dramatske poezije. Obično pjesnici - pisci, koji su dalek[o?] od teatra i njegovim predstavnicima pokažu u svojim djelima neznanje za „ono“, štono se veli „du théatre“, ma da su djela pisana po svim pravilama[sic] dramskog umijeća.

U Vašoj pjesi[sic] „Šegrt Hlapić[“] osim živog humorističnog monologa i dijaloga ima i dobru karakteristiku likova, ima u nekojim slikama i djelotvornog efekta, naime one dramatičke - tajne sile.

Ali - u koliko i ima krasote - to je glavna figura i c[i]jeli komad zu breit ausgespanen, im epische Breite geraten. Nicht nur der Protagonist - die gesamte Handlung verlangt Kürzungen, verlangt stärkere Konzentration mehr noch: eine Überarbeitung [odveć raširen, dospio je u epske širine. Ne samo protagonist cjelokupna radnja iziskuje kraćenja, zahtjeva veću koncentraciju štoviše: preradu]. „In der Beschränkung zeigt sich der Meister“ sagt Göthe [,U ograničenju očituje se majstor", kaže Goethe]. Razumije se, to ograničavanje nije tako lahko provesti. Kritizirati ipak je lakše nego producirati.

Dašto - imade toliko krasnih misli i prispodoba, dosjetljivosti da je šteta brisati. No - potrebno je. Monologi su predugi - i - osim toga - unmodern; - Der Monolog ist 
ja an und für sich - unnatürlich - also als solcher nicht „du théatre“ [nemoderni; Monolog je sam po sebi i za sebe - neprirodan - kao takav, dakle, nije „du théatre“]. S etičkog, estetskog i pedagoškog gledišta Hlapić je divan, primjeran lik: Kada bi mu se dalo koncentričniju formu, - radnja bila bi dramatičnija. Hlapić jest protagonist djela. Ako bi se skratila radnja - izkočio bi bolje antagonist (crni čovjek) - jer „strah i bojazan“ ovi glavni motori u drami*, dakle bojazan za dobroga Hlapića dovelo bi ono za dramu najnuždniji element: die „Spannung“, di[e] grössere dramatische Spannung [,napetost“", veću dramsku napetost].

Sa svim svojim odlikama i skraćenjem nikakove Snjegoručke i slični produkti nebi se mogli sa Hlapićem uzporediti.

Ja sam se usudila u nekim govorima brisati neka izlišna mjestanca, opetovanja - no više se ne usudim. Nemogu preuzeti odgovornost.

Ako bi se Vi veleštovana gospodjo dali na tu operaciju - na skraćenje bolje rečeno na preradbu, to bi hrvatski repertoar za našu mladež - za naše djačke predstave imao etičan komad literarne vrijednosti. Komadima ovog žanra mi ne obilujemo - na žalost. Imamo zabavnih, no malo značajnih. Ali šegrt Hlapić u Vašem djelu jest značaj ${ }^{* *}$. On je zlatna dušica, on je personifikacija čistoće i dobrote - a to je uzvišeni cilj čovječanstva.

Ja Vam čestitam [na] karakterizaciji ovoga lika i - k lijepoj Vašoj duši i duhovnosti. Uz izraz najiskrenijeg počitanja

Vaša štovateljica

Ivka K. Milarova ${ }^{27}$

U Zagrebu 29. juna 931.

* po teoriji Aristotela i Lessinga

${ }^{* *}$ uz to, da je zabavan. ${ }^{28}$

Arhiv obitelji Brlić, kutija inv. br. 80, svežnjić 61 .

23. svibnja 1932.

Na gđu Josipu Mondeckar

Brod na Savi 23/V. 1932.

Visokocijenjena gospođo!

Bila sam dugo vremena odsutna, zato Vam tek sada odgovaram na Vaše cj. pismo.Pristajem na to da roditeljsko vijeće preuzme prvu izvedbu moje dječje igre „Šest konaka šegrta Hlapića“.-- Uobičajeno je da 15\% od brutto dohodka pripada autoru,

${ }^{27}$ Ivka Milarova-Kralj (1856. - 1942.), hrvatska glumica.

${ }^{28}$ Bilješke uz zvjezdice napisala je autorica pisma. 
pa Vas molim da mi javite da li ovo konvenira Vašem cj. udruženju. Ja sam na manuskriptu naznačila koje glazbene umetke držim za prikladne, no ako Vaša režija ima druge glazbene nakane ( $\mathrm{tj}$. da se upravo za taj komad nešto nova dade) to bi se svakako željela sa skaldateljem sporazumjeti. Dakako da bi onda na njeg imao odpasti neki dio od gore spomenutih 15\%.- Uvjerena sam da će Roditeljsko Vijeće stvar lijepo i dotjerano izvesti, jer ima najveći kontingent mališana, pa će biti lako naći prikladne male glumce za Hlapića i Gitu, o kojima ovisi cijela izvedba.Kad dođe vrijeme za pokuse, molim Vas svakako da me obavijestite, jer bih Vam odmah u početku rada saopćila neke moje želje u tom pogledu.- Manuskript neka ostane kod Vas - samo u slučaju da bilo s kojega razloga ne dođe do izvedbe, želim svakako da mi se povrati.

Molim Vas da budete tako ljubezni pa da mi još prije početka praznika potvrdite primitak ovog mog pisma i da mi javite pristajete li na moje uvjete. Stvar će se možda (pače sigurno) morati skratiti, pa ako to skraćenje učini Vaš režiser, to bih svakako rado vidjela to skraćenje, da ne ispa[d]ne štogod što je po mom mnenju bitno.

I ja se nadam uspjehu, osobito ako uočimo popularnost „Roditeljskog Vijeća“, spojenog sa popularnošću malog Hlapića. Radovati ću se tom uspjehu već poradi toga, što ćemo tolikim mališanima, uz zabavu i šalu, dati moralne poduke, toliko nužne u ovo doba!

Osobitim štovanjem

I. B. M.

Arhiv obitelji Brlić, kutija inv. br. 80, svežnjić 64 .

6. veljače 1933.

Brod 6/II 1933

Draga moja Nada!

Hvala Ti na milom pismu i na fotografiji * za „Vampa“, kojim ste neliepim prišvarkom okrstili jednu kako vidim dražesnu curicu. Al Ti neimaš pojma koliko, već od njenih prvih fotografija, uviek i uviek Manuccia nalazim podpuno u njenom licu! - Sliku valjda mogu zadržati? Ti nasuprot, Nadek, moraš mi poslati natrag one dvie fotografije: Hlapića sa Gitom i Nedu. Neimam više, a moram uspomenu na tu uspjelu stvar sačuvati.

Jako mi je drago da je genealogija ,upalila“.- 1) Ona prababa zove se Ana Gonin, a godinu će Zdenka eruirati [utvrditi] iz Vukovara.-2) Mama od stare mame umrla 
je kad se je Željko rodio, dakle valjda 1882 ili 1883 - no moramo to kod Željka doznati iz onog Bernatovog albuma.- 3) Na mojoj genealogiji je izpravno godina mamine smrti, samo je repić na „9“ tako mal da izgleda kao nula. 4) Danas ću pisati Laszowskom radi obih familija Canjuga i Daubachy. Uvjerena sam da bi to lahko išlo - a kako mi Laszowski jučer piše za podporu za obnovu Ozlja to bi samo trebalo imati 50 ili 100 D. za tu svrhu, pa bi [,,]čovjek sa licem“ mogao tražiti heraldičke usluge.

Savjetuješ mi da Nedjeljka piše odgovore na obiteljska pisma. A tko bi onda u referatima od 6 araka rješavao psihičke odnose izmedju Volumnije i Coriolana i tko bi produbio jesu li senatori bili podli a narod „bezazleno zloban“! Moja draga, nije to šala!

Što se Hlapića tiče prilažem Ti ovo pismo Ivino koje molim kretom pošte natrag. Bude li se Hlapić u Z[a]gr[e]bu davao to držim da nebi bilo dobro da ga načmemo na Sušaku. No ja nevjerujem da će do toga doći jer to moraju silne intrige biti.- Hlapić „bi bio, bojim se prevelika zadaća za školu“, premda su ovdje djeca već cieli I. čin bila u školi naučila i uživala. Samo je onda ravnateljica dobila straha pred tim velikim podhvatom. Ja ću Ti poslati drage volje cielu stvar, pa pregledajte. Ja si tako silno želim da to dodje do izvedbe, da mi se već svi rugaju. Al što ćeš! Jučer mi u loncu procvao jedan prosti prostacti jaglac kojega već 3 godine prenosim po sobama. I to me više veseli nego sve divotne azaleje koje podobivasmo za rodjendane. Tako je i sa mojim „Hlapićem“ koji mi ide više po glavi nego Nobel!Neka mi dakle piše Ninčevićka želi li ga! Svakako bi Ti morala pomoći da se skrati. Ovako bi trajao skoro 3 sata. Za deklamaciju bi moglo nešto iz „Valjani i Nev.“ili iz „Škola i praznici“ biti. Ono sa zvjezdicom je češki.-Imam opet mnogo zanim[lj]ive, koresp.- no o tom drugi put.

Mama.

Šaljem Ti danas 2 zanimiva, prem stilistički grozna, predavanja Bučarova. Koliko taj čovjek ima podataka! - unglaublich [nevjerojatno].

Sve više se divim kako si Ti zaista svoj rukopis dotjerala!

Spomenička knjižnica i zbirka Mažuranić-Brlić-Ružić, Villa Ružić, Rijeka

19. srpnja 1933.

U Zagrebu 19. VII 1933.

Visoko poštovani gospodine doktore ${ }^{29}$,

Već sam Vam jučer na telefonu napomenuo kako je Pripov[i]jest o šegrtu Hlapiću kod naše mladeži jedna od najmilijih knjiga i da će je jedva dočekati da je

${ }_{29}$ Pismo je upućeno dr. Ivi Brliću (1894. - 1977.), sinu Ivane i Vatroslava Brlića. 
ugleda sa naše scene i kao dramu. Naglasio sam da je pripov[i]jest tako dobra, a da je dramatizacija oslabila čitavi dojam pripov[i]jesti, i da je bezuvjetno potrebno, da se nanovo dramatizira i udesi za današnju modernu scenu. Tražili ste od mene da Vam sve ono, što sam Vam potanko razložio na telefonu, dadem još i pismeno. Da vidite, da sam imao pravo, zamolio sam poslije našeg razgovora g. redatelja Mesarića, da mi i on navede primjedbe sa svoje strane i Vi ćete se začuditi, kako se one na vlas slažu, iako se nas dvojca prije toga nismo razgovarali.

Evo njegovog mišljenja:

"Priča o "Čudnovatim zgodama šegrta Hlapića" kadra je da već kod samoga čitanja oživi dječju fantaziju. Zgode su vjerojatne, njihov razvoj nije uvjetovan nikakovom natprirodnom i nadzemaljskom iznenadnom pomoći. Radnju ne pokreće nikakav naivni deus ex machina, nikakve vile, ni kraljevne, ni vukodlaci. Sve se razvija prirodno, nenametljivo, uvjerljivo. Jednostavno i neforsirano naglašen je i etički momenat u priči. Tu nema tendencioznog moraliziranja, pa ipak moral priče postoji povezan sa samom fabulom. Mjestimično je tek nabačen, a zvuči poput biblijske sentencije. Ova je knjižica tužnih i veselih, požrtvovnih i šaljivih doživljaja maloga Hlapića jedna od rijetkih u dobrom smislu savremenih i literarno odličnih lektira za djecu.

Sve prednosti ove priče, koje se očituju kod čitanja mogle bi još jače i neposrednije da djeluju u adekvatnoj dramatizaciji. Ta dramatizacija trebala bi da bude po duhu, sadržaju i scenskoj tehnici jednako savremena, priprosta i srdačna, kao što je i priča. Onda bi ona postigla svoju svrhu.

Dramatizacija te priče o Hlapiću pod naslovom "Šest konaka šegrta Hlapića" zaostaje nažalost za pričom. U toj je dramatizaciji jednostavnost dječjih dialoga bez potrebe komplicirana, tehnika nalik na zastarjele féerije ${ }^{30}$ u neskladu sa aktuelnošću priče, a nekoje vanredno žive scene iz priče neiskorišćene. Jednako je tako ostao nedovoljno izoštren i dramatski zaplet fabule.

Sama priča daje dovoljno materijala, a moderna scena dovoljno mogućnosti, da dramatizacija ove priče obuhvati veći kompleks zbivanja u većem broju slika.

Moje je mišljenje, da bi nova dramatizacija provedena u gornjem smislu mogla da ima isti plemeniti, korisni i efektni učinak na djecu, kao što to još uvijek ima izvrsna priča 'O čudnovatim zgodama šegrta Hlapića' .“

Evo, to su primjedbe g. redatelja Mesarića. Kako vidite, one se poklapaju posve s onim što sam i ja naveo jučer Vama, visoko poštovani gospodine doktore, na telefonu. Držim, da će zato biti najbolje, da se dramatizacija dade g. redatelju Mesariću ili g. redatelju Titu Strozziju. Oni, kao poznavači današnje scene, učinit

${ }^{30}$ Féerie - scenski žanr s tematikom o vilama i drugim nadnaravnim bićima, utemeljen u folklornoj tradiciji, s posebnim scenskim efektima, popularan u Francuskoj u 19. stoljeću. 
će iz te izvrsne priče i jednako izvrsno dramatsko djelo, koje će još jače ugoditi našoj djeci, i time povećati zanimanje i za samu priču. Znam da sam trebao da napomenem samo današnjoj djeci, da namjeravamo u narednoj sezoni izvoditi „Priču o šegrtu Hlapiću“, pa da vidite kako su klicala od veselja. Ne mogu da zaboravim, i kakav je dojam ta priča još prije 15 godina učinila na mog sina, pa Vam sve to najbolje svjedoči, da su djeca upravo zato zavolila tako tu priču, jer ona sebe u njoj zajedno sa svojim drugovima nalaze. Kad god sam pitao djecu, što vam se u toj priči tako dopada, odgovorila su mi vazda: tu smo mi; to je sve tako naše i sve je tako naravno i prirodno, a ne kao u onim ludim pričama o vilama i vješticama!

Visoko Vas poštuje

J. Bach $^{31}$

Arhiv obitelji Brlić, kutija inv. br. 80, svežnjić 67.

16. studenoga 1933.

Brod na Savi, 16/XI. 1933.

Dragi moj Viktore ${ }^{32}$ !

Ovo pismo je samo pismo zakašnjele uljudnosti naprama Tebi, drago diete. Jer doznati nemožeš iz njega ništa, što Ti moj higijenski socijalni uzorni „manager“ nebi sto put bolje bio opisao. Kako znaš ja sam u području higijene jedno atrophirano nedonošče, a na području socijalnosti jedan hipertrophirani, recimo: instrumenat, na kojemu i ugodne i neugodne melodije sa tisućstrukom snagom o[d]zvanjaju. $U$ Beču je, nakon obavljenih doktorskih dužnosti, „melodija“ bila neobično skladna, tiha i ugodna - dakle su doktorske upute, mnenja i medicine, imale podporu u družtvenim ugodnostima, koje smo si Nada i ja znale udesiti prema mojim silama: vrlo umjereno i ,gewählt" [,odabrano“, „otmjeno“]. Sigurno je da je moj „manager“ donekle kod toga stradao jer je za mene n. pr. „gewählt“: Rouacher [Ronacher], dočim se na „Fausta“ $u$ Burgtheateru nisam usudila sa slabim sadanjim kapacitetom.- Ali cijeli je ovaj podhvat, drago diete, i onako bio sa svih strana žrtva za vas: za Tebe, za Nadu i za dječicu. Bude li pako koristi, a ponajprije: prodje li kod malog Vikića i kod ostale dječice sve bez zdravstvenih posljedica - to ćemo, uvjerena sam svi skupa složno i suglasno zaboraviti i težke ove moje mjesece i sve muke, žrtve i neprilike - a ostati će medju nama samo obnovljena,

${ }^{31}$ Josip Bach (1874. - 1935.), hrvatski glumac i redatelj, ravnatelj Drame (1931. - 1934.) i glavni tajnik (1921. - 1935.) Hrvatskoga narodnoga kazališta.

${ }^{32}$ Viktor Ružić (1893. - 1976.), suprug Nade Brlić, kćeri Ivane Brlić-Mažuranić, ministar pravde Kraljevine Jugoslavije i ban Savske banovine. 
nanovo i na usko spojena ljubav. Već onog dana, kad si u vinogradu tako milo i strpljivo slušao i pobijao, ali i shvatio, moje tadanje težke depresije - već onda je ta obnovljena ljubav dobila svoju pravu direktivu. Pa hajde da ne požalimo što si tada radi preduge naše „konference“ [razgovora, rasprave] valjda zakasnio na brzovlak i pročitao deset strana manje Gregoroviusa! Da nepožalimo ni to, ni ništa drugo što je sliedilo! - Ja za sada žalim samo jedno mjesto - u crievima, za koje konačno svi vrači pogadjači nisu pogodili: zašto me bole? A ono prau genau ${ }^{33}$ boli dalje. No sad je moja i vaša savjest mirna, a anatema može sada još pasti samo na zadocnjelu majčicu medicinu.

Ja sad imam punu glavu ex librisa, predstave „Hlapića“, Zdenkinog namjeravanog čitanja „Nostalgije“ u Beogradu, prepisivanja nekih pjesama za moje nove bečke drugove - dakle kako vidiš u ovoj buri i oluji moje bolesti ipak nisam uspjela da udavim svoj ,jaizam“. Moram ga dakle nositi barem sa toliko „Anstanda“ [dostojanstva] sa koliko je Cyrano nosio svoj veliki nos.-

Grlim Te, drago diete, i čekam težko viesti o Vikiću.

$$
\text { Tvoja Mama }
$$

Aleksa Te moli da javiš što je dalje sa gruntovničarskim mjestom Katinim?

Arhiv obitelji Brlić, kutija inv. br. 101, svežnjić 2.

${ }_{33}^{33}$ Budući da riječ 'prau' ne postoji u njemačkome jeziku, pretpostavljamo da bi značenje izraza prau genau moglo biti: A ono me prav za prav/doista/odista/baš vraški boli dalje. (op. prev. T. E.) 


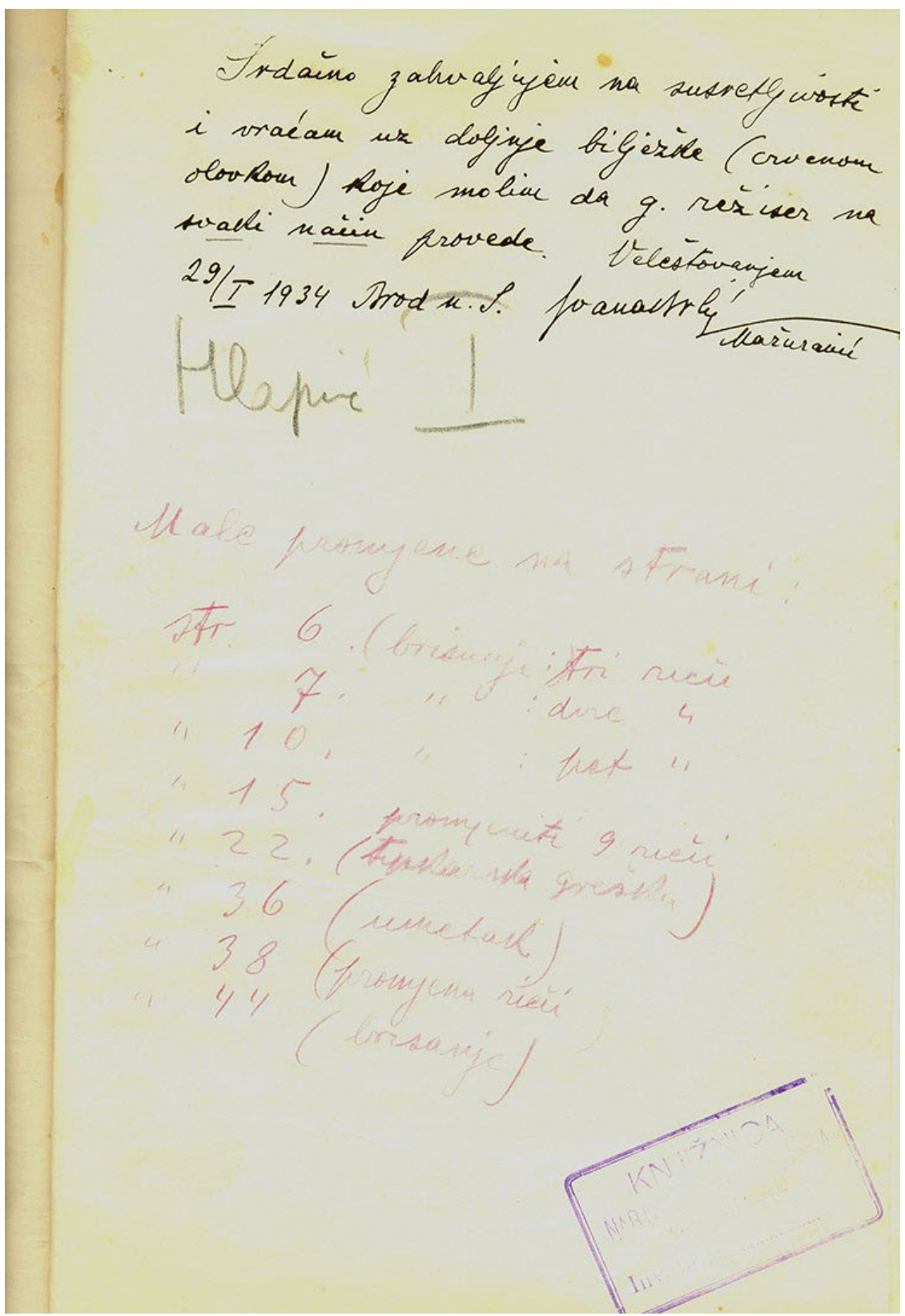

SI. 8. Bilješka Ivane Brlić-Mažuranić na koricama rukopisa dramatizacije romana, od 29. siječnja 1934.

Fig. 8 Note by Ivana Brlić-Mažuranić on the back cover of the manuscript of the dramatization of the novel, dated 29 January 1934. 
29. siječnja 1934.

[Upisano na zadnjim koricama strojopisnog primjerka Strozzijevog Šegrta Hlapića koji je očito bio na čitanju kod Ivane Brlić-Mažuranić.]

Srdačno zahvaljujem na susretljivosti i vraćam uz daljnje bilježke (crvenom olovkom) koje molim da g. režiser na svaki način provede.

Veleštovanjem

Ivana Brlić Mažuranić

29/I 1934 Brod n. S.

Hlapić I [Dopisano običnom olovkom.]

[Crvenom olovkom:]

Male promjene na strani:

str. 6. (brisanje :) tri rieči

“ 7. " : dvie “

“ 10 . " : pet “

“ $7 . \quad$ " : dvie “

“ 15 . prom[i]jeniti 9 rieči

“ 22. (tipkarska greška)

“ 36. (umetak)

“ 38. (promjena rieči)

“ 36. (brisanje)

Arhiv obitelji Brlić, kutija inv. br. 85, svežnjić 13.

7. ožujka 1934.

Zagreb, 7. III. 1934.

Visokocijenjena milostiva gospodjo!

Oprostite mi što Vam se tek danas javljam i odgovorim[sic] na Vaše cijenjeno pismo - no toliko sam bio zaokupljen radom u kazalištu, da dosada nisam prije dospio da Vam se javim.

Pokusi za „Hlapića“ napreduju vrlo lijepo i ako sam radi bolesti male Lee Deutsch (Gite) imao prekid pokusa od 10 dana. Nadam se da će stvar izaći početkom mjeseca aprila, a držim najkasnije do 10. IV. o.g.

Skice za scenu već su izradjene, i po mom sudu vrlo su uspjele.

Što se tiče Vaše bojazni, milostiva gospodjo, da će stvar predugo trajati, mogu Vas uvjeriti da je i u mom interesu da komad ne traje dulje već najdulje do 1/4 11 - a pošto sam ga mjestimice skratio, ne će sigurno dulje ni trajati. Kako majka male Lee sa malom dolazi u subotu 10. o. mj. u Brod, biti će lako slobodna da Vas sa malom posjeti, te će Vam tom prilikom mnoge detalje ispričati.

Budite milostiva gospodjo uvjereni da ću ja kao i glumci (mali i veliki) uložiti sav 
trud i napor da Vaša toli dražesna stvar što ljepše, bolje i dostojnije uspije.

Uz izraze iskrenog poštovanja

ostajem veleštovanjem

Alfons Verli3

Arhiv obritelji Brlić, kutija inv. br. 81, svežnjić 5.

26. ožujka 1934.

Zagreb, 26. III: 1934.

Visoko poštovana milostiva gospodjo!

G. redatelj Verli predao mi je tri Vaše fotografije, od kojih Vam dvije vraćam, a treća će biti reproducirana u našem kazališnom tjedniku „Komedija“.

Vaš krasan interesantan članak o postanku „Hlapića“ će biti odštampan u cijelosti, pa Vam ga uslijed toga ne šaljem na skraćivanje. Naša „Komedija“ će sve učiniti, da publiku dolično unapred pripremi za premijeru Vašeg divnog i osjećajnog djela.

Izvolite primiti, milostiva gospodjo, izraze mog najodličnijeg poštovanja kao i rukoljube

dr. S. Batušić3 ${ }^{35}$, tajnik Nar. Kazališta i urednik „Komedije“.

Arhiv obitelji Brlić, kutija inv. br. 81. svežnjić 5 .

7. travnja 1934.

Narodno kazalište Zagreb

Zagreb, 7. aprila 1934.

Visoko poštovana milostiva gospodjo,

Oprostite mi, što Vam na Vašu dopisnicu od 23. III. o. g. nisam odmah odgovorio, ali kako je upravo u to vrijeme obolila mala naša Lea Deutsch, to Vam uz najbolju volju nisam mogao odgovoriti da li je moguće da bude premijera Hlapića 7. IV.

Nadao sam se da će možda mala ozdraviti prije, pa da će se moći premijera Hlapića dati na 18. o. mj., dakle upravo na dan jubileja. ${ }^{36}$ Ali kako mala još nije izašla iz svoga stana, to ćemo istom po njezinoj sutrašnjoj šetnji moći zaključiti, da li se mala toliko oporavila, da bi se premijera mogla održati bilo koncem ovoga mjeseca ili početkom narednog mjeseca.

G. redatelj Verli kaže mi, da Vas je svojevremeno o tim neprilikama sa malom obavijestio, pa zato nisam htio da Vam isto pišem.

Žao mi je, što se neda ostvariti premijera na dan 18. aprila, pa ako bi stanje

${ }^{34}$ Alfons Verli (1892. - 1940.), hrvatski redatelj.

${ }^{35}$ Akademik Slavko Batušić (1902. - 1979.), kazališni djelatnik, pisac, povjesničar umjetnosti.

${ }^{36}$ Misli se na 60. rođendan Ivane Brlić-Mažuranić. 
male bilo u ponedjeljak takovo, da bi se možda ipak premijera mogla davati što prije, ja ću Vam to smjesta saopćiti.

Uz rukoljub i odličnim

poštovanjem

Josip Bach

Arhiv obitelji Brlić, kutija inv. br. 81, svežnjić 5 .

18. travnja 1934.

18. Travnja 1934.

Vrlo poštovana gospođo!

Dozvolite mi, da Vam i privatno čestitam na jubileju i na izvrsnom djelu, kojega ste darovali hrvatskoj mladeži, sa željom, da se ispune one riječi, koje ste 17. ov. mj. rekli sa pozornice, e da imate volju još 60 godina živjeti. Bio bi neobično sretan, kad bi naša hrvatska javnost proslavila uz Vašu prisutnost 60-godišnjicu postanka „Čudnovatih zgoda šegrta Hlapića“.

Dozvolite mi, milostiva gospođo, da Vam u ime svih nas mlađih, koji smo s uživanjem čitali Hlapića i s njim u duhu putovali, i u ime onih koji slijede, da Vam čestitam.

Kad bi naša hrvatska omladinska literatura imala još jedno djelo Hlapićeve vrijednosti, onda se ne bi bojala drugih naroda, ni njihovih djela. Dobra je ona, što je g. Horvath u „J. L.“ rekao: „Mažuranićka je hrvatski Andersen“, ali bi ja na to dodao još i ovo: „realni““.

Molim Vas, milostiva gospođo, da mi ovo primite s onom istom ljubavlju, kojom i šaljem.

Vaš sam iskreni poštivaoc:

Dalibor Vučica ${ }^{37}$

Zagreb, Solovjeoljeva[sic] 9. II. kat

Arhiv obitelji Brlić, kutija inv. br. 81, svežnjić 6 .

${ }^{37}$ Dalibor Vučica, kritičar i dječji pisac. 


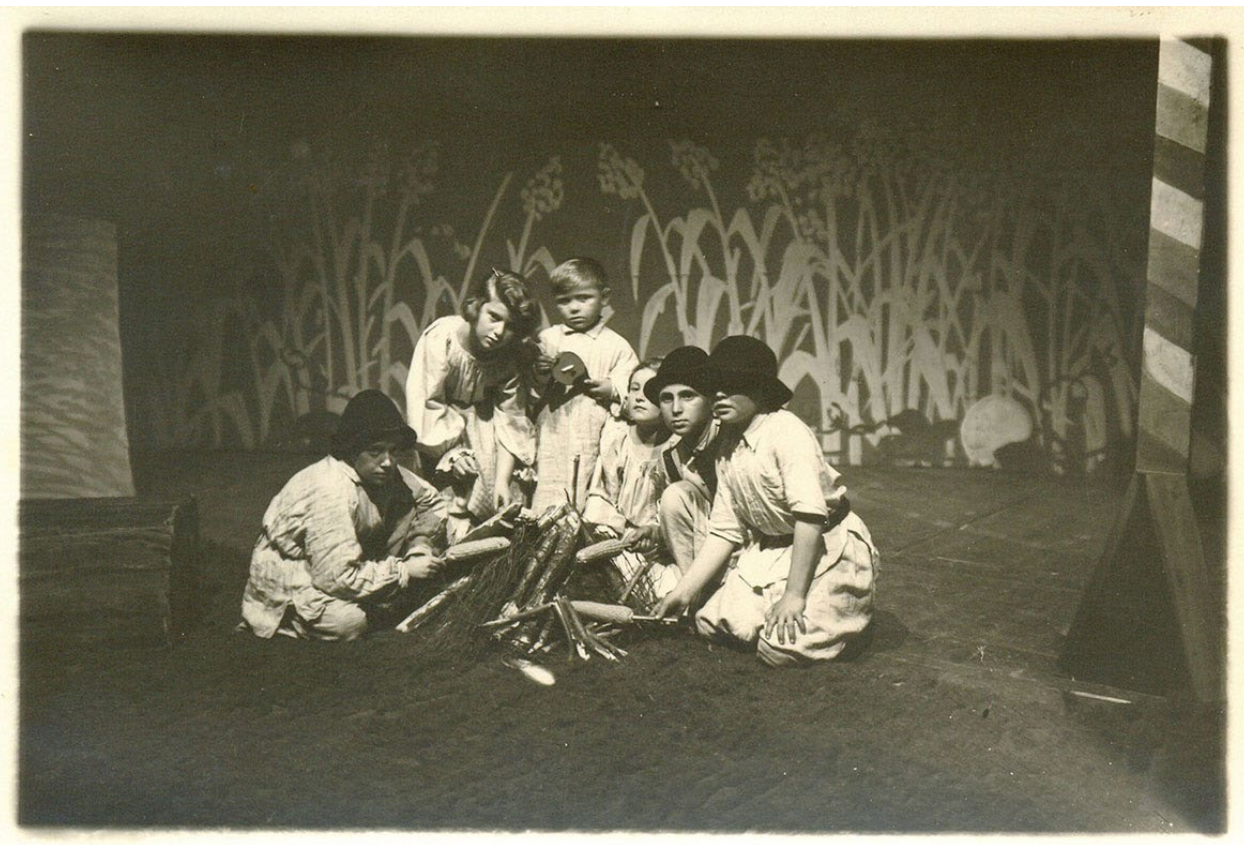

S1. 9. Predstava Šegrt Hlapić, dramatizacija: Tito Strozzi, redatelj: Alfons Verli, scenografija: Edo Kovačević. Premijera 17. travnja 1934. Nakon premijere predstava je imala još osam izvedbi. Pastirići peku kukuruz na otvorenoj vatri.

Fig. 9 Performance of Šegrt Hlapić [Hlapich the Apprentice], dramatized by Tito Strozzi, directed by Alfons Verli, scenography by Edo Kovačević. Premiere on 17 April 1934. There were eight repeated performances. Little shepherds roasting corn on the cob over an open fire.

20. travnja 1934.

Univ. doc. Dr. Jos. Lončar ${ }^{38}$, Zagreb

Klaićeva 11.

20. IV. 1934.

Dragi Ivo!

Moja mala Rajkica, za koju znadeš da je s velikim veseljem čitala „Šegrta Hlapića“, bila je i na premijeri drame. Po njezinoj želji evo šaljem i Tvojoj mil. gdji. mami od nje složenu čestitku, kojoj se od srca i moja žena i ja pridružujemo. Kako vidiš, nije zaboravila ni Gitinu papigu nacrtati. Šaljem Tebi pismo, jer ne znam momentane adrese gdje majke, a Ti joj prigodice, ako misliš da će je interesirati, pokaži ili pošalji priloženu kartu.

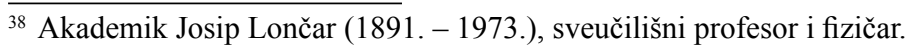


$\operatorname{Mnog}[$ sic $]$ Te od srca pozdravlja

Tvoj Jozica Lončar

[Na pismo pisano strojopisom, očito naknadno, Ivana Brlić-Mažuranić je svojom rukom dopisala: „To je Jozica Lončar Nadin „kolega“ i njegova kćerka, koja mi je jednoč u vlaku skoro cijelog Hlapića na pamet deklamirala."]

Arhiv obitelji Brlić, kutija inv. br. 81, svežnjić 5

20. travnja 1934.

\section{Ugovor $^{39}$}

sklopljen izmedju Narodnog Kazališta, zastupanoga po upravniku g. Konjoviću Petru s jedne i gospodje Brlić-Mažuranić Ivane i g. Strozzia Tita s druge strane.

$\S 1$.

Gdja Brlić-Mažuranić Ivana i g. Strozzi Tito pisac odnosno priredjivačtramatskog djela Čudnovate zgode šegrta Hlapića, dječje igre u 14 slika ěinustupa Narodnom Kazalištu pravo prikazivanja ovog djela u zgradi Narodnog Kazališta i na svakom mjestu, gdje kazališna uprava priredi prikazivanje djela. Ovo pravo ne smije pisac u području grada Zagreba bez dopuštenja kazališne uprave prenijeti na koga drugoga.

$\S 2$.

Upravnik Narodnog Kazališta u Zagrebu preuzima današnjim danom u §-u 1. ovog ugovora navedeno po piscu gdji Brlić-Mažuranić Ivani i priredjivaču g. Strozzi Titu ustupljeno pravo, te se naročito obvezuje, da će bilo njemu, bilo njegovu valjano iskazanom punomoćeniku isplatiti temeljni honorar od $\mathrm{D}$-tantieme.

Femeljni honorar isplatit ée se drugi dan iza prve predstave. Ovaj će se honorar obračunativši sa $15 \%$ brutto prihoda od prvih dviju predstava i ... \% od svake daljne predstave. i to da autorica prima $60 \%$ od tantieme a priredjivač $40 \%$.

$\mathrm{Ne}$ dosegnu li ove tantijeme temeljni honorar neée pisae biti obvezan išta od njega povratiti, a presegnu li, isplaćivat ée kazališna uprava na kraju svakoga mjeseea piseu višak, koji nadilazi taj temeljni honorar.

Brutto-prihod sačinjava prihod od dnevnih ulaznica i abonentske kvote ložâ i sjedalâ uz odbitak dnevnih troškova u najvišem iznosu od $\mathrm{D}$.....

Prihod od garderoba, buffeta, kazališnih cedulja, pretprodajnih pristojba i poreza na ulaznice, ne računa se $u$ brutto-prihod.

\section{$\S 3$.}

Upravnik se kazališta obvezuje, da će djelo, spomenuto u §-u 1. ovog ugovora prikazivati u Narodnom Kazalištu najdulje do dne 18. aprila 1934. ne zapriječi li to koja vis maior (bolesti, štrajkovi, spoljašne zapreke, potresi, elementarne nezgode,

39 Tipski ugovor. Sve što je u ugovoru dopisivano rukom, u ovom je prijepisu pisano kurzivom. Neki tipski dijelovi ugovora rukom su precrtani, kao što ovdje stoji u prijepisu. 
dvorska korota $\mathrm{i}$ t. d.). Obvezuje se podjedno prikazivati to djelo i drugi put i to najdulje 10 dana iza premjere, ne zapriječi li to i opet koja vis maior.

\section{$\S 4$.}

Upravnik se obvezuje, da će djelo iznijeti u opremi dostojnog djela, a glede opreme i podjeljenja uloga postupat će artistička uprava s piscem sporazumno. U slučaju nesporazuma medju njima odlučuje upravnik Narodnog Kazališta. Bude li potrebno preduzeti u djelu kakve preinake, učinit će to uprava u dogovoru sa piscem.

\section{$\S 5$.}

Ako pisac preradi svoje u §-u 1. navedeno djelo, protežu se ovim ugovorom stečena prava i na preradjeno djelo.

$\S 6$.

Prekrši li kojagod stanka bilo koju od ustanova ovog ugovora, platit će konvencionu kaznu u iznosu od polovice temeljnoga honorara, ali ugovor ostaje i dalje u kreposti, ako povrijedjena stranka ne zatraži, da se razriješi.

\section{$\S 7$.}

Ina autorska prava piščeva ostaju netaknuta.

$\S 8$.

Dodje li do kakvoga spora, podvrgavaju se obje stranke nadležnom sudu u Zagrebu.

\section{$\S 9$.}

Ovaj ugovor staje na snagu onim časom, kad ga obje stranke potpišu.

Ugovor se izdaje u jednom izvornom primjerku, koji pridržaje kazališna uprava, a piscu daje se prijepis.

Trošak za biljeg na ovaj ugovor nose obje stranke u polovici.

U Zagrebu dne 20. travnja 1934

Za Narodno Kazalište:

[potpis nečitljiv, Petar Konjović ${ }^{40}$ ]

Svjedoci

Josip Bach

S. Batušić

Pisac:

Ivana Brlić Mažuranić

Priredjivač:

Tito Strozzi ${ }^{41}$

Arhiv obitelji Brlić, kutija inv. br. 68, svežnjić 13.

\footnotetext{
${ }^{40}$ Petar Konjović (1883. - 1970.), srpski skladatelj i glazbeni pisac. Ravnatelj Opere (1921. - 1926.) i intendant (16. veljače 1933. do 17. kolovoza 1935.) Hrvatskoga narodnoga kazališta.

${ }^{41}$ Tito Strozzi (1892. - 1970.), hrvatski glumac, redatelj i dramatičar.
} 

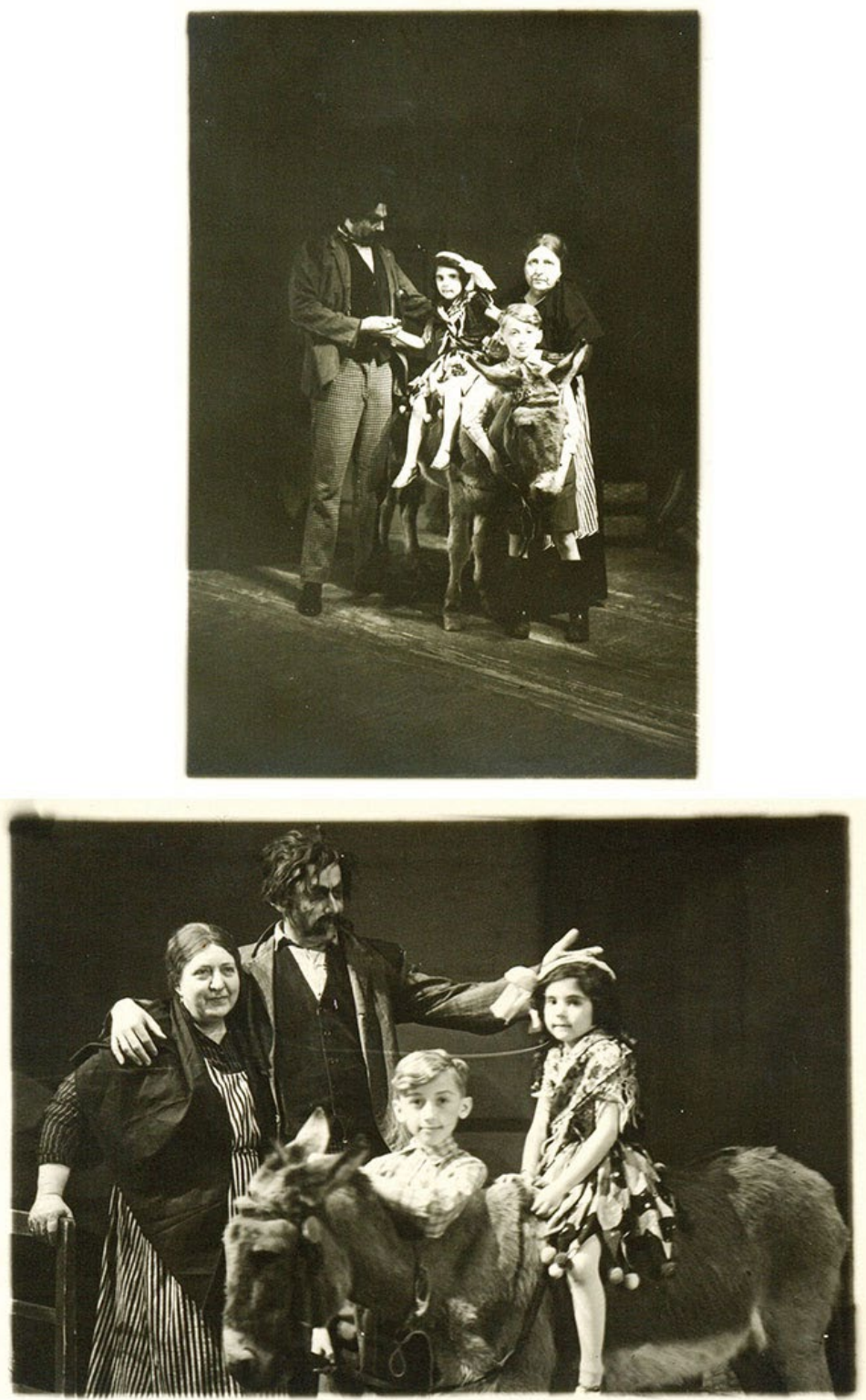

Sl. 10. Dvije fotografije s predstave Šegrt Hlapić. Mrkonja: Mato Grković (1898. - 1973.), dramski glumac i redatelj. Gita: Lea (Dragica) Deutsch (1927. - 1943.), glumica. Majstorica: Bogumila Vilhar (1882. - 1962.), glumica. Hlapić: Ivan Braco Reiss (1923. - 1984.), glumac i komičar.

Fig. 10 Two photographs from the performance Šegrt Hlapić [Hlapich the Apprentice]. Mrkonja played by Mato Grković (1898 - 1973), theatre actor and director. Gita played by Lea (Dragica) Deutsch (1927-1943), actress. Majstorica (the Master's Wife) played by Bogumila Vilhar (1882 - 1962), actress. Hlapić played by Ivan Braco Reiss (1923-1984), actor and comedian. 
20. travnja 1934.

Izvadak iz pisma o reprizi „Hlapića“ 20,[sic] IV - 1934

Kazalište je bilo prilično puno. Za čudo većinom su bili stariji ljudi a djece veoma malo. Trebalo bi apsolutno udesiti posljepodnevne predstave, te bi sigurno bile više posjećene. Sama pretstava[sic], da Ti iskreno kažem, nije bila tako efektna kao prvi puta u velikom kazalištu. Mnogo čini ambient, mislim reći prilično „simple“ izgled maloga kazališta. „Hlapić“ je kroz to dobio neki mirni, realni izgled, što je svakako na nas odrasle dobro djelovalo, ali na djecu nipošto. Djeca zaht[i]jevaju stanovitu „briljancu“ komada. Aplaus[sic] je zato bio najveći iza prizora u kojem prvi puta dolazi „crni čovjek“, te iza prizora gdje Hlapić gasi vatru, a Gita pleše. To su uostalom bezuvjetno najbolje scene čitave pretstave. Scena sa Gitinim plesom silno je živa i puna dinamike. Tako nješto trebaju djeca. Vidio sam kako su dvije male curice skočile sa sjedala, te htjele poletiti naprijed od silnog oduševljenja, da iz bližeg vide tu čudesnu scenu.

Šteta što Verli nije proveo one promjene te što smo morali opet gledati „stari“ završetak „Hlapića“. Držim da je velika pogreška ona neka stanovita gužva daljnjih slika. /slika sa košaračem, slika pred cirkusom, slika u cirkusu/ sve tako zgruvano, nervozno i kratko kao kakova „momentaufname“ [snimka jednog trenutka], pa usljed toga sve skupa nerazumljivo i konačno si čovjek i neda truda da razumije. Scena u šumi je izvrsna, samo bi se momenat kada Mrkonja nailazi na djecu morao mnogo efektnije izradit, možda duljom pripravom za taj moment: šuškanjem, pucketanjem, možda dalekom grmljavinom i. t. d. Na koncu sve je to za djecu, a tu se mora impresionirati u pravoj mjeri dječjoj, Sjećam se i sam što sam volio kad sam bio dijete: onako fina groza, da te mala jezica hvata, a onda iznenada happy end [sretan kraj]!-

No glavna je pogreška i tu sam se uvjerio da imaš potpuno pravo: konac se apsolutno mora prom[i]jeniti. U predzadnjem činu n. p. /kada dolazi ono „,i vi vičite: živio Hlapić“" kraj mene su se nekoji ustali, jer su mislili da je kraj pretstave. Isto se dogodilo i u sljedećoj slici kad Gita sjedne majstoru na krilo i počme pričati, a zastor padne- $\mathrm{i}$ opet nesporazum te ljudi misle da je sada zbilja kraj, a kad tamo komad se nastavlja posve nepotrebno, dok se konačno po treći put ipak svrši u nekoj nevoljkoj dispoziciji publike. Ovaj trostruki kraj morao bi se bezuvjetno preudesiti i skratiti da bude komad u svom drugom dijelu isto tako izvrstan kao u prvom. Djeca su upravo izvrsno igrala.

Oprosti što ti ne pišem onako „divno i umiljato pismo“ kako ih sada dobivaš, no ti si me poslala da te izvjestim o reprizi, a ja sam to onako iskreno učinio. Velim još jednom: konac se mora izmjeniti, jer šteta da ovako krasna stvar bude radi par nepotrebnih pogrešaka pokvarena. 
Hlapić će sigurno, kad se ovi nedostatci izglade, postati upravo klasičan komad, koji mora svuda kuda dodje imati velikog uspjeha.

Ljubim ti ruke i kličem ,živio Hlapić“.

$\mathrm{H}^{42}$

Arhiv obitelji Brlić, kutija inv. br. 81, svežnjić 5.

28. travnja 1934.

Narodno kazalište Zagreb

Dne 28. aprila 1934.

Milostiva gospodjo,

zahvaljujući na Vašem ljubeznom pismu, čast mi je izvijestiti Vas, da sam Vaše želje u vezi sa izmjenama u Vašem komadu uputio gosp. Strozzi-u koji će učiniti sve što bude moguće, te Vas o tome i izvijestiti.

Druga prestava[sic] Vašega „Hlapića“ nije bila tako dobro posjećena, jer se je davala naveče. Medjutim smo odlučili, da ga u buduće dajemo kao popodnevnu predstavu, što će nam bezuvjetno osigurati dobar posjet.

Izvolite, milostiva gospodjo, primiti izraz mog najdubljeg poštovanja.

Upravnik:

Petar Konjović

Arhiv obitelji Brlić, kutija inv. br. 81, svežnjić 5.

30. travnja 1934.

Zagreb 30. IV. 1934.

Milostiva gospođo!

Izvolite primiti ove slikice za uspomenu na prvu izvedbu Vašega lijepoga Hlapića. Ovo je moja najmilija uloga i ja se veselim svakoj izvedbi kao premijeri.

Bio sam sa mamicom u hotelu da Vas zamolim, ako bi se htjeli sa mnom slikati, ali Vi ste nažalost već odputovali.

Srdaćne[sic] pozdrave Vašim unucima a Vama mnogo rukoljuba od Vašega Hlapića

\section{Brace Reissa ${ }^{43}$}

Rukoljub od Bracine mame tate i sekice

Arhiv obitelji Brlić, kutija inv. br. 81, svežnjić 6.

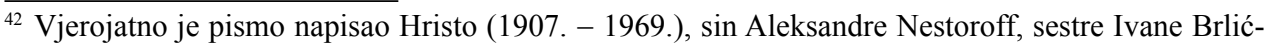
Mažuranić, kojemu je, kao petogodišnjaku, roman o Hlapiću u vrijeme nastanka bio namijenjen.

${ }^{43}$ Ivan Braco Reiss (1923. - 1984.), hrvatski glumac i komičar.
} 


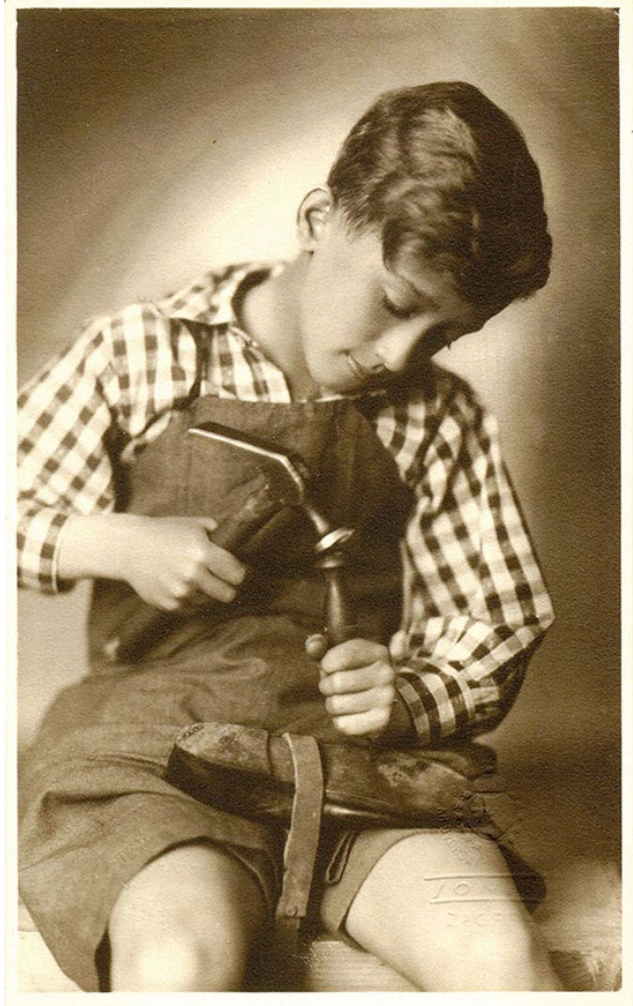

Milostivay gosprodi Brlic" outarici maje najlépé ulage, us rukaljub Braco Reiss Zagreb uyeseca travija
1.934

SI.11. Braco Reiss kao Hlapić i posveta Ivani Brlić-Mažuranić na poleđini fotografije.

Fig. 11 Braco Reiss as Hlapich and a dedication to Ivana Brlić-Mažuranić on the back of the photograph.

\section{2. svibnja 1934.}

Zagreb 2. V. 1.934.

Draga milostiva!

Strašno sam se veselio Vašim dragim knjigicama sa prekrasnom posvetom i lijepim slikama. Najljepše Vam zahvaljujem i uv[i]jek ću ih čuvati i kada budem stari.

Ja neznam[sic] ništa češki, ali Hlapića čitam i sve razumijem, kad je sve tako poznato i kao nekako moje.

Dok sam još bio sasvim malen najviše sam volio kad mi je mamica čitala „Šegrta Hlapića“. Uvjek sam se igrao, da sam ja Hlapić i jednom sam skoro dobio od tate batina jer sam u njegove nove cipele zabio čavle. Ali mamica se zauzela za 
mene, pa sam sretno prošao. Ali dedek i babica kada su to saznali zvali su me dugo „Šegrt Hlapić“، Za to sam ja mogao dobro igrati Hlapića jer ga jako volim.

Kod posljednje predstave, kada Crni čovjek pita: „Šta je to mali? Tvoje čižmice?“ Vikao je jedan mali dječak iz parketa: „Ta, da, da su njegove! Beži Hlapić!“" Mali je plakao, a ja sam se morao okrenuti, da se ne vidi kako se smijem i skoro sam zaboravio dalje govoriti. Svi su se ljudi u kazalištu smijali. Bilo je to jako zgodno. Prošle subote malo sam kod predstave šepao, jer je u školi bio pod namazan uljem, pa sam opal i nategnul žile. Ali sada je već sasvim dobro. Samo naš dobri gospodin Verli je jako bolestan i mora na operaciju. Ali mi ćemo svi koji ga volimo molit za njega, pa će ga dragi Bog čuvati.

Još jednom najljepša hvala na knjigama.

Mnogo, mnogo rukoljuba šalje Vam

\section{Braco Reiss}

Milostiva gđo!

Dozvolite da Vam i ja zahvalim na poslanom. Nemožete pojmiti kako ste veliko veselje učinili mome dragom sineku i kako je ponosan na Vaš dar.

Oprostite Bracinome pismu koje vrvi ortografskim pogrješkamai kajkavštinom, ali htjela sam da Vam sasvim ,samostalno“ zahvali.

Još jednom srdaćna[sic] hvala!

Rukoljub [nečitljiv inicijal] Reiss

Arhiv obitelji Brlić, kutija inv. br. 81, svežnjić 6.

\section{2. lipnja 1934.}

\section{Slavnoj}

upravi narodnog kazališta Zagreb

G. Dr. Leo Rotter odvjetnik, Zagreb - podizati će kod blagajne kazališta tantijeme za moju dječju glumu „Čudnovate zgode šegrta Hlapića“" te ga ovime na to ovlašćujem.

\section{Veleštovanjem}

Ivana Brlić-Mažuranić

Zagreb. 12/VI 1934.

Arhiv obitelji Brlić, kutija inv. br. 80, svežnjić 5. 


\section{9. lipnja 1934.}

Mil. gospodja

Brlić-Mažuranić

Brod na Savi

Zagreb, dne 19. juna 1934.

Mnogopoštovana milostiva gospodjo!

Nakon razgovora $\mathrm{s}$ g. dr. Rotterom slobodan sam glede zastupstva Vaših autorskih prava djela „,ŠEGRT HLAPIĆ““ na tonfilmsku reprodukciju predložiti Vam sljedeče $[$ sic $]$ :

ad 1./ Ja preuzimljem zastupstvo Vaših autorskih prava za tonfilmsku reprodukciju za djelo „کSEGRT HLAPIĆ““ za tu-i-inos transtvo[sic]. Od prihoda koje budu ubrani u Kraljevini Jugoslaviji ili iz inostranstva ulaze u Kraljevinu Jugoslaviju za autorsko pravo tonfilmske reprodukcije odobravate mi proviziju od $10 /$ deset/ $\%$.

$\operatorname{ad} 2 . /$ U jedno mi predajete pravo plasiranja Vašeg romana , „کSEGRT HLAPIĆ“"u svim evropskim zemljama osim Čehoslovačke, gdje je knjiga već štampana.

ad 3./ U koliko u roku od godinu dana ne bi plasirao prije spomenuto djelo ulazite ponovno potpunoma u posjed Vaših prava i ovaj se sporazum smatra razriješenim. Uspije li mi plasiranje pod 1./ ili samo pod 2./ ostaje taj dio sporazuma na snazi

ad 4./ Obvezujete se staviti mi na raspolaganje tri češke knjige i kratke izvadke na njemačkom jeziku, sve to najkasnije tri ned[j]elje posl[i]je sklopljenog ovog sporazuma.

Molim, da mi protupismom izvolite potvrditi saglasnost sa prednim[sic] sporazumom

Odličnim veleštovanjem Albini

podpisala ovaj ugovor i poslala Dodatak prihvaćen po Albiniju 3/VII 1934:

kopiju sa podpisom Rotteru 25/VI Gornje utanačenje prihvaćam uz ove 1934 preinake: 1) Šegrt Hlapić nesmije biti tonfilmski snimljen dok ja ne pregledam tzv Drehbuch [scenario]. 2) Zastupstvo za pravo pr[ij]evoda novele „Hlapić“ predajem g. Albiniju samo za one zemlje u kojima ne postoji još zgotovljeni prijevod tog djela, te ću Vam saopćiti gdje i koji prevodi postoje. IBM Brod na S. 3/VII 1934

Arhiv obitelji Brlić, kutija inv. br. 81, svežnjić 5. 


\section{9. lipnja 1934.}

\section{dr. Leo Jacobi}

dr. L. Rotter

$$
\text { Zagreb, 19. VI. } 1934 .
$$

Mnogo poštovana milostiva gospodjo,

Primio sam Vaš c. dopis od 14. o. mj. s prilozima, a još prije toga razgovarao sam u smislu našeg dogovora s g. Albiniem. Ovaj mi je odmah saopćio, da sad više ne bi ni mogao preuzeti zastupstvo Vaših autorskih prava glede drama, već samo onda, ako pristupite udruženju Jugoslavenskih dramskih autora, kojega je on za Zagreb generalni zastupnik. Prilažem pod ./. primjerak pravila toga udruženja, pa mi izvolite javiti, jeste li spremni da stupite u to udruženje. Prema članu 12. pravila pripalo bi udruženju 10\% od tantijema i honorara izuzevši dakako zagrebačke / Albini dobiva od toga od udruženja 2\% /, tako da Vi ne biste imali nikakovih drugih obveza prema udruženju ni Albiniu, dok bi ono prema članu 2. preuzelo obvezu promicati Vaše interese. Vaš pristup u članstvo može se ograničiti samo na Vaša dramska djela. Ako pristupite, onda će Albini kao generalni zastupnik udruženja dakako brinuti se naročito oko placementa Hlapića na tu i inozemnim pozornicama. Smatram, da bi pristup u udruženje bio u Vašem interesu, pa mi izvolite saopćiti Vašu odluku.-

Drugčije stvar stoji glede autorskih prava za tonfilmsku reprodukciju [rukom dopisano: i sv. prerade, koji još postoje (to valja u ugovor još staviti)]. U tom pogledu može Albini samostalno raditi, pa predlažem po njemu potpisani ugovor s kopijom, koju izvolite za slučaj da utanačenje prihvatite potpisati i meni povratiti u svrhu uručenja g. Albiniu. -

Poznato mi je, da Albini imade sasvim dobrih veza sa praškim AB filmom. Ova tvrtka baš traži jedan jugoslavenski sujet za filmovanje, pa će u tu svrhu uskoro doći u Zagreb direktor tog poduzeća Reichling /ovaj imade zagrebčanku za ženu/. Albini mi je obećao, da će ga zainteresirati za Hlapića i da će me obavijestiti kad taj gospodin stigne u Zagreb. Dodje li, nastojat ću ishoditi kod uprave kazališta, da bi se dala predstava Hlapića, da Reichling stvar uzmogne vidjeti na sceni. Dobro je, da postoji češki prijevod Hlapića, pa izvolite prema želji Albinijevoj poslati tri češka primjerka i kratki izvadak na njemačkom jeziku. Ako potonje nemate; dat ćemo načiniti.-

Ne uspije li stvar s AB filmom pokušat će Albini s kojom amerikanskom tvrtkom s kojima takodjer imade veza.

Primjećujem, da bi se Hlapić vjerojatno filmovao na temelju originalnog teksta a ne po priredbi[sic] g. Strozzia tako da ovaj u tom slučaju ne bi participirao. - 
Glede honorara za antologije obratio sam se na Minervu i biblioteku u Smederevu, pa ću Vam resultate saopćiti.-

Jeste li Dayre-u odgovorili na njegov upit glede Vaših primjedaba u pogledu prijevoda Šume Striborove? -

Očekujem Vaše vijesti, pa Vas i ovom zgodom, milostiva gospodjo, najsrdačnije pozdravljam.

Odani Vaš Leo Jacobi

Arhiv obitelji Brlić, kutija inv. br. 81, svežnjić 5.

2. srpnja 1934.

Dr. L. Jacobi

Dr. L. Rotter

Mnogo poštovana mil. gospodjo!

Zagreb, 2. jula 1934.

Primio sam Vaše pismo od 24. o. mj. s prilogom t.j. utanačenjem, koje vraćam pod/nadopunjeno odnosno ispravljeno prema Vašim željama, pa molim, da ga ponovno potpišete i meni povratite radi uručenja g. Albiniju. Ovaj mi je upravo javio, da direktor Reichling od A. B. filma za sada neće doći u Zagreb, no da će se on već brinuti oko plasmana.

Vaše želje u pogledu ograničenja prigodom pristupa u Ujdu dostavio je g. Albini udruženju, pa kad stigne odgovor saopćit ću Vam ga.

Minervi sam javio, da prihvaćamo ponudu glede honorara. Iz Smedereva nema odgovora.

Primite milostiva gospodjo, izraz moga velikog poštovanja.

\section{Leo Jacobi}

M. b. Molim, da mi pripošaljete tri češka primjerka Hlapića i kratki izvadak na njemačkom jeziku radi uručenja g. Albiniju, i da mi javite koji prijevodi Hlapića do sada postoje.

\section{Leo Jacobi}

[rukom pisano]: odg. 3/VII i poslala ugovor.

Arhiv obitelji Brlić, kutija inv. br. 81, svežnjić 5. 


\section{7. kolovoza 1934.}

Narodno kazalište Zagreb

Zagreb, 17. VIII. 1934.

Visoko poštovana milostiva gospodjo,

po povratku sa službenog putovanja zatekao sam ovdje Vaše cij. pismo od 2. o. mj., na koje mi je čast odgovoriti Vam, da je Vaš komad „Šegrt Hlapić“ svakako stavljen na repertoar za izvedbe u slijedećoj sezoni 1934/35., i to naročito za nedjeljne dječje popodnevne predstave. Prva izvedba „ŠSegrta Hlapića“ u novoj sezoni predvidjena je već u nedjelju 2. septembra o. g. popodne.

Izvolite primiti, milostiva gospodjo, i ovom zgodom izraze mog najodličnijeg poštovanja.

\section{Upravnik, \\ Petar Konjović}

Arhiv obitelji Brlić, kutija inv. br. 81, svežnjić 5.

22. kolovoza 1934.

dr. L. Jacobi

advokat

dr. L. Rotter

advokat

Zagreb 22. 8. 1934.

Milostiva gospodjo,

Primio sam Vaše vrlo poštovano pismo od 15. o. mj., a još prije toga dva primjerka Hlapića u češkom izdanju, te njemački resume Hlapića, što sam sve predao g. Albiniu. Tom prilikom razgovarao sam s njime o Vašim stvarima, pa mi je saopćio, da se za Hlapića interesira Matica hrvatskih kazališnih dobrovoljaca, kojoj je predstavnik g. Freudenreich. Ovih dana bit će prilike, da s njime razgovaram, pa ću se za stvar interesirati.-

Osim toga saopćio mi je g. Albini, da se u Pragu jedna manja pozornica interesira za stvar. Glede plasmana za film nastojat će zainteresirati i neko američko poduzeće.-

U Celju imao sam prilike razgovarati s upravnikom g. Konjovićem, pa mi je obećao, da će i u budućoj sezoni davati Hlapića.- [rukom upisano:] S Verliem ću razgovarati.

U Laškom bilo je sasvim lijepo, pa sad čekam na efekt kupanja. Nadam se, da je Vama Vaš boravak u Dobrni koristio. 
Primite i ovom zgodom, milostiva gospodjo, uz srdačne pozdrave i izraz mog velikog poštovanja:

\section{Leo Jacobi}

Arhiv obitelji Brlić, kutija inv. br. 81, svežnjić 5.

1934.

[Bilješka Ivane Brlić-Mažuranić u jednom od strojopisa dramatizacije]

Generalni pokus 16. IV. 934. u 3 h p. p.

Svrsi u $10^{15} \mathrm{~h}$

V. K. premiera - 17. IV. 1934.

M. K. 20. IV. 934.

V. K. 22. IV. 934.

M. K. 28. IV. 934.

6. V. 934.

V. K. 10. V. 934.

V. K. 13. V. 934.

V. K. 21. V. 934.

V. K. 8. IX. 934.

[V. K. - Veliko kazalište, tj. HNK; M. K. - Malo kazalište, tj. današnje kazalište Gavella]

Arhiv obitelji Brlić, kutija inv. br. 85, svežnjić 12.

24. rujna 1934.

Narodno kazalište Zagreb

Zagreb 24. IX. 1934.

Visokopoštovana milostiva gospodjo,

dolazim tek danas, radi preobilja posla u Kazalištu, da Vam se zahvalim na prekrasnom brodskom groždju. Pošiljka je u izvrsnoj kondiciji stigla u Zagreb, tako da smo si doista mogli dočarati sve ljepote jeseni u brodskom vinogradu.„Hlapića" smo do sada odigrali tek jedanputa i to pred dosta slabo posjećenom kućom, no to nije ni čudo, jer je tek početak sezone i teatar je općenito slabo posjećivan. Nadam se, da se[sic] tokom sezone posjet biti bolji.

Primite milostiva gospodja još jednom moju najsrdačniju hvalu na priposlanoj pošiljci, te bilježim

Sa odličnim veleštovanjem

odani Vam

Alfons Verli

Arhiv obitelji Brlić, kutija inv. br. 81, svežnjić 5. 


\section{5. listopada 1934.}

Dr. L. Jacobi

advokat

Dr. L. Rotter

advokat

Zagreb, 5. 10. 1934.

Milostiva gospodja,

primio sam Vaše poštovano pismo od 29. pr. mj., te sam temeljem punomoći podigao kod Narodnog kazališta za Vas tantijem za predstavu Hlapića od 8. 9. o. g. Tantijema iznosila je svega 143. din., pa sam Vam taj iznos po odbitku biljega na punomoć i namiru i porta od 17 din., dakle ukupno 126.- din. doznačio pošt. uputnicom.-

Što se tiče moga troškovnika slobodan sam na Vaš upit saopćiti Vam, da za sada nisu za Vas kod mene nastali nikakovi troškovi. Kad postignemo uspjeh onda ćemo se glede troškova već sporazumjeti. -

Razgovarao sam ponovno sa Albinijem. On je i opet pisao u Varšavi i Beograd. Čim bude šta javit ću Vam se. -

Primite milostiva gospodjo i ovom zgodom izraz moga velikog poštovanja. -

Leo Jacobi

Arhiv obitelji Brlić, kutija inv. br. 81, svežnjić 5.

18. studenoga 1934.

Draga Zdenka ${ }^{44}$ !

Beograd 18/XI 1934.

Imam jednu malu prisilnu dokolicu, pa držim da je dobro, da ju upotrebim za zabilježbe o ovim mojim zgodama.-

Stigli smo Ivo i ja u četvrtak 15. XI. u večer u hotel „Srpski kralj“. U hallu [predvorju] našli smo Željka, Darka, grofa Torijosa (od španjolskog poznanstva [poslanstva?]) i neke Engleze. Dosta za prve pol ure.- Večerali smo en famille [opušteno, kao kod kuće] i nadmudrivali se, dakako, u svakoj temi: počam od „djulbastije“ i od ,wassersemmla“"45, pa do visoke politike, u svemu je svaki od familije htio biti najpametniji - ali mu i onako jalov posao, kad je Darko to mjesto zauzeo, a radi šepave noge ne može da bude zbačen. - U 1/2 10 pošli smo u hotel

\footnotetext{
${ }^{44}$ Zdenka Benčević, rođ. Brlić (1899. - 1984.), kći Ivane i Vatroslava Brlića.

${ }^{45}$ Ponovno austrijski dijalekt, inače sinonim za Wasserbrötchen, vrstu peciva.
} 
"Excelsior“ na dogovor sa Švrljugovima ${ }^{46}$ radi audijencije. „Excelsior“ nadaleko zaostaje u ljepoti položaja za „Srpskim kraljem“. Moja divna, ogromna soba u „Srpskom kralju“ (sa kupaonom) gleda na Kalimegdanski park i uživa sama u sebi i u svojoj cijeni od 140. Din.- Kod Švrljugovih u „Excelsioru“ dvije sobe lijepo i skladno udešene. Gđa. Švrljuga u crnini, mila, vanredno srdačna - a kraj njene lijepe pojave i uvijek harmoničkog, a ipak toplog držanja, imaš dojam, da je jedamput netko pogodio baš na pravo mjesto.- Dogovorili smo se da ću ipak, usprkos korote, ponijeti moje knjige Kraljici. Ako dvorski auto ne bude sutradan u $1 / 211$ pred „Srpskim kraljem“, neka podjemo vlastitim autom do maršalata dvora. Išli smo naime zajedno: Željko i ja, jer sam bila odredjena u audijenciju na Dedinju za 11 sati, Željko za 1/2 12, a Darko za 12 sati. Računali jadni bez blagoglagoljivosti „braće Beaugeste!“- - U 3/4 11 dakle odosmo Željko i ja vlastitim autom do maršalata, koji je u dvoru u centru Beograda. Sve je, dakako, još pokriveno crnim suknom: portal, - Kraljeva slika, zrcala - pa se u toj crnini odižu još jasnije crvene uniforme orijaških gardista stražara, koji se ukočili kraj ulaza.- Dočekao nas je neki mladi, vrlo ugladjeni činovnik, a velika, tmurna dvorana, stara po izgledu i dosta prazna, sa teškim pokućstvom, činila je tužan dojam. Na desno su mala hrastova vrata, kuda se je išlo u krilo dvora, gdje je Kralj stanovao, dok nije preselio na Dedinje. Ovdje je Željko često išao na audienciju; u 11 sati manje 10 minuta došao je dvorski auto. Unišli smo Željko i ja, ponijeli paket knjiga u običnom papiru, povezano bijelom svilenom vrpcom - i eto nas gdje jurimo put Dedinja. Desno i lijevo posve mlada, vitka stabalca jablana, na vrhovima svaki nosi krunu jesenskoga lišća - a jesensko sunce i jesenski vjetar izvodi svoju spontanu ornamentiku sa tim zlatnim krunama, što se zibaju i što šibaju strelohitno uz naš ,ubrzani“ auto.-

Samo narav i jedino ona može da iznenadno unese vedru notu i u najsjetniju duševnu dispoziciju. Možeš mi naime vjerovati da mi se srce upravo fizički stezalo i suze neprestano dizale na oči, kada sam pomišljala, da eto jurim zapravo u mrtvi grad, u grad mrtvog kralja, kojega tamo neću ni zateći, niti si ga dočarati moći. Mrtav je čovjek mrtav! - tu neima pomoći i sva naša fantazija i sva naša žudnja da to ne bude tako, samo povećavaju našu bol i našu strepnju, koja mora uvijek nastati, kad padne središnji stup gradjevine, a pokrajni stupovi tek treba da dokažu da su dobro postavljeni i dovoljno jaki. -

Bilo kako bilo, jablanova radosna stabalca i njihovo strijeljanje uz auto, donijela su života i novo poleta u mene - i eto nas: jednim majstorskim ,aterisažom“ [slijetanjem] šofera stane auto elegantno i žustro uz samu prvu stepenicu dvora

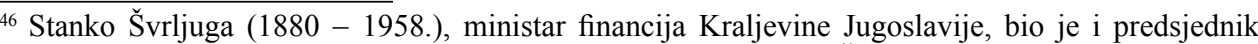
Zagrebačke burze za robu i vrednote. Njegova supruga Eleonora Švrljuga, barunica Economo, rođ. Glaser, Mariborčanka, bila je dvorska dama kraljice Marije Karađorđević. 
na Dedinju. Uz sama vrata parka projurili smo prije toga uz posebnu, kako mi se čini šesterokutu zgradu, pokrivenu debelim slamnatim krovom, po uzoru zagorskih seljačkih kuća. U toj kući stanuju sada mali kraljevići, pošto je mali Kralj Petar sada odijeljen od braće, te samo dolazi k njima u odredjeno vrijeme.

Na stepenicama dvora dočekao me je Kosta ${ }^{47}$ - lijep kao igda, prijazan, vedar, u svojoj bespri[je]kornoj uniformi, sa pojasom, koji valjda označuje njegovu čast adjutanta Kralja. Možeš si misliti, da mi je bilo drago što sam ovako direkte na prvom koraku iz dvorskog auta pala, tako rekuć, u naručaj (i to učtivi i ljubezni naručaj) Koste.- Željko, koji je po navadi cijelim putem šutio i razmišljao, bio je očito isto tako prijatno iznenadjen, kad je ugledao Kostu, te čuo moj oduševljeni pozdrav. Vidio moj brajko, da se riješio brige za mene ovom prilikom.- Kroz veliki, al vanredno ukusni „hall“ (sa grozom pomišljam na „ungemütlich“ [neudobno] ogromni „hall“ kod Meštrovića, koji mi je zamjerio sve „hallove“!) odveo nas Kosta u biblioteknu[sic] dvoranu, koja ima velika staklena vrata, otvorena na prekrivenu terasu. Pogled na vrt je krasan, no nije dozvoljeno hodati po vrtu, što sam ja, ne znajući za tu zabranu, skoro prekršila. Izašla (dok smo Željko i ja sami čekali u biblioteci) ja lijepo na terasu i da ću u vrt. Al se Željko prenuo iz svojega „transa“, pa me zovnuo natrag- Na ogromnom stolu biblioteke leže prekrasna djela, većinom ilustrirana i to takvog velikog formata, kakovog zapravo još nisam vidila. Zabavili smo se nekom zbirkom slika u boji „les Sultans Ottomans“.- Bila sam odredjena u audijenciju za 11 sati, ali mi dodje Kosta javiti, da je iznenada morala biti umetnuta audijencija ministra Jevtića, koji je sutradan odlazio u Ženevu, da preda u Ligi Naroda memorandum Jugoslavije o Marseljskoj tragediji (Da ih Bog ubije, koji nam je nametnuše u srce i pod pero!).- Čekala sam još nekih 15 minuta a onda dodje Kosta i javi mi, da sam ja na redu. Knjige za Kraljicu, za mladog Kralja i za Kraljeviće bile su već odnešene gore. Ja dakle samo još malo ukrijepih svoj Kalabreski šešir i eto me u mojoj dugačkoj crnoj haljini, sa abbee cipelicama br. 36, sa zlatnim Strossmayerovim krstom oko vrata i sa crnom rukavicom na lijevoj ruci izlazim kao neki prelat, elastičnim korakom uz Kostu u hall. Tu me dočekala gdja. Švrljuga: u crnini, u izvrsnom šeširu sa dugačkom koprenom, sa onim vanredno svježim, bijelim i rumenim slovenačkim licem a visoka, skladna i otmena - moram opet reći: kad sam se u hallu našla izmedju Koste i gdje. Švrljuge, pomislila sam da zaista ni na jednom dvoru sadašnjosti ili prošlosti nije moglo biti boljih i reprezentativnijih figura, negoli su ove dvije, koje smo mi „prečani“ dali Dedinju. I misleći tako na posve teoretske stvari, penjala sam se uz gdju. Švrljuga

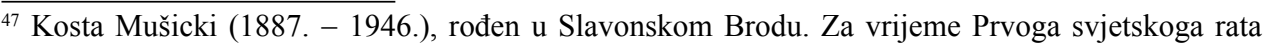
služio je u Austrougarskoj vojsci, a za Drugoga svjetskoga rata bio je zapovjednik Srpskog dobrovoljačkog korpusa u Nedićevoj Srbiji. 
po mramornim, ne preširokim, stubama, pokrivenim crvenim sagom, u prvi kat. Moje petice $8 \mathrm{~cm}$ visoke, lupkale su žustro gdjegod su uz crveni sag mogle uhvatiti malo golog mramora - a uz mene nečujni korak Dvorske gospodje. I eto nas na jedna širom otvorena vrata. Predsoblje Kraljice. Veliko, odugačko, sa skulpturama i bronzama. Prodjosmo hitrim korakom do jednih zatvorenih vrata. „Ovdje“, reče gdja. Švrljuga sotto voce [ispod glasa] i otvori vrata. Salon srednje veličine, no lijevo odmah uz vrata paravant - iza paravanta teška kožnata garnitura i niski stol za knjige, te police za knjige.- Nasred salona stoji Kraljica ${ }^{48}$. U teškoj crnoj haljini, $\mathrm{u}$ struku nabranoj u guste nabore, koji padaju do zemlje, gornji dio haljine isto kao da pada u neku pelerinu, a lice uokvireno crnim, bijelo obloženim „kapotom“, koji se svojim velom spušta na pleća. Čini posve dojam jedne mlade predstojnice samostana.- Po prijašnjoj uputi ,pozvanih faktora“ učinim odmah kod vratiju prvu reverence-u, našto gdja. Švrljuga reče: „Dozvolite Vaše Veličanstvo, gdja. BrlićMažuranić moli, da Vam iskaže svoje osjećaje.“ Kraljica pristupi korak prema meni i pruži ruku posve u susret meni, ja pobrzam 3 koraka napred i učinim svoju reverence-u (br. 2. u ovaj dan, a br. 3. u mom cijelom životu!). Na to Kraljica pokaže rukom prema garnituri iza paravanta, podje tamo, spusti se u duboki fotelj, ja sjednem u drugi i izgubim ovime iz vida gdju. Švrljuga, koja za mene nestane iza paravanta. Čini mi se, koliko sam mogla posmatrati vrh od vratiju, da je odmah izišla.- Kraljica odmah započe razgovor i to jezikom, kojega ja - draga moja Zdenka - mogu po mom najboljem uvjerenju hrvatskim nazvati, jer sam 60 godina govorila tim jezikom u potpunom uvjerenju, da govorim hrvatski i jer sam sad, ne mogu Ti reći kakav osjećaj sreće osjetila, što moja jugoslavenska Kraljica govori za mene nedvoumno tim mojim hrvatskim jezikom. „Moram Vam zahvaliti za Vašu prekrasnu (naglašeno) tako duboku i osjećajnu pjesmu. Bila sam kod čitanja te pjesme tako dirnuta -“. Suze joj se digoše u oči i prinesav ruke licu malo stane. Je li čudo da je i mene, pred ovom mladom, uzornom i sada tako nesretnom ženom savladao osjećaj - a pogotovu strepnja od budućih dana ? Tko bi ju bio mogao gledati ovako mladu, ovako u odijelu koludrice, ovako rastuženu i ovako zaista milu - tko bi to mogao, a da ne bude i sam ganut možda i malo više negoli potpada u okvir jedne audijencije. „Vaše Veličanstvo“, rekoh zatim, „na žalost ova strahovita zgoda sama po sebi stvara duboku pjesmu u svima nama!“- „Da“, reče Kraljica, „to je bilo strašno, strašno“. Pošto me je gdja. Švrljuga molila da se ne udubimo u tu tragediju, kako bi Kraljica izašla bar donekle iz te bolne atmosfere, rekla sam: „Bilo je i više nego strašno - no Vaše Veličanstvo ima pred sobom tako silnu zadaću,

${ }^{48}$ Marija Karađorđević (Gotha, 1900. - London, 1961.), kći rumunjskoga kralja Ferdinanda I. i kraljice Marije, nećakinje engleskoga kralja Edvarda VII. i unuke kraljice Viktorije. Rodbinski je bila povezana i s ruskom kraljevskom obitelji. 
da Vas ta zadaća mora prevesti u vedrije raspoloženje. Vaša zadaća oko odgoja djece, koja za jednu cijelu državu tako rekuć sve znače, mora Vašem Veličanstvu da podigne i dušu i srce iz ovog strašnog bola“. - „O, da! moja djeca!“ izreče Kraljica toplim i uzbudjenim tonom, te je sve što slijedi u tome tonu govorila. „Moja djeca, to je posao i dužnost moja! Ja imam jednu gotovu osnovu o njima. Svi, svi treba da mi u toj osnovi pomažu. Ja želim oko te djece okupiti jednu legendu, ja želim njih uklopiti u tu legendu, želim da oni budu dio te legende i nadam se, da ću upravo time od njih učiniti ono, što je moja i njihova dužnost." Uzdignuv donekle desnu ruku, finom i protančanom gestom poduprla je ove svoje riječi, dok je vidljivo uzbudjenje podiglo rumen u lice i sjaj suze u oči. „Vaše Veličanstvo, ne mogu Vam izreći, kako je divno, što Vi - naša Kraljica - ovako formulirate nakane svoje.- Ne pristoji meni, kano gospodji, da izričem političke riječi, no poslije ovoga, što je Vaše Veličanstvo kao majka našeg mladog Kralja izrekla, smijem i ja reći, što od prvog trena ove nesreće mislim.[“] Naime: „Država počiva, Vaše Veličanstvo, sada poglavito na Vašim plećima, jer o Vama ovisi odgoj našeg mladog Kralja.“ Na to ona, pogledavši me časkom reče: „Da, pravo imadete. Ali je time i moja (ovdje prvi put zastade, tražeći pravu riječ, dok joj ja ne pomogoh riječju ,odgovornost“) odgovornost veća i teža.“- „Dakako, Vaše Veličanstvo, tim više što su prilike pod kojima je uzrastao blagopokojni Kralj Aleksandar bile tako stavljene, da je jedan jednostavni, strogi odgoj, kojega im je Kralj Petar i pružao, bio mnogo lakše provediv nego li će biti u ovim prilikama. Ako dozvolite, Vaše Veličanstvo, pričat ću Vam dvije tri zgodice iz doba kad je Kralju Aleksandru bilo 15-16 god.“ „Molim, molim!“ reče Kraljica; a ja upućena po gdji. Švrljuga, da Kraljica upravo napetom pažnjom sluša sve, što se tiče djetinjstva Kralja Aleksandra, ispričah joj dvije zgode iz dobe, kad je Kralj Petar jednakom pomnjom, brigom i strogošću odgajao kraljeviće Gjorgja, Aleksandra i sinovca princa Pavla.- „Da, da, to je sasma on (Aleksandar) kakav je i poslije bio“, prim[i]jeti Kraljica na jednom mjestu.„Samo u rukama Vašeg Veličanstva leži da stvori za odgoj svoje djece sve ono što je u odgoju Kralja Aleksandra bilo samo po sebi dano. [“]- „Imadete pravo, al moj Petar je dobro i poslušno dijete, a ja se nadam, da će sva mlada generacija biti onakova, kakova mora da bude“.- „O, Vaše Veličanstvo, da Vi znadete, koliko je tragična i zaista žrtvena smrt Kralja potresla mladež i da kažem njemački „auslösovala“ [izazvala] sve najbolje iz mladeži. Mladež je, dakako, prije svega uhvatila vitešku, sentimentalnu, romantičnu notu - ona je konačno opet našla svog heroja, kojemu nitko ni u sadašnjosti ni u budućnosti nemože osporiti taj naziv. Pišu se medju mladeži pjesme, komponiraju se žalobne koračnice, modeliraju se oltari, pokušavaju se pisati drame.“- „Da,“ reče Kraljica, ,, m mladeži je nada naša. A žalost je bila tolika, da se je i u kući osjećala ona velika vibracija žalosti.“ - „Ima jedna 
mala pjesmica jednog slastičarskog sinčića, koju je pjesmicu na dan žalosti napisao pod Kraljevu sliku. Dozvolite!“ „In ker je Tebi, mrtvi Kralju, izvršit bilo nemogoče, To bo dovršil sin Tvoj z nami v bodoče.”- Kad sam tu pjesmicu recitirala i opet su rumen i suze došle na obraz Kraljice. „Molim Vas, to je upravo ono, upravo ono! Gdje je to bilo?“. „Na Sušaku, Vaše Veličanstvo, u slastičarskom izlogu.“ Nekako mi se činilo, da je Kraljici ,izlog“ strana riječ, i rekoh: „in der Auslage“ [u izlogu] Dalje je razgovor tekao njemački. „Das Volk war halt dem König so nahe, das lag in ihm, dem König, es war nicht äusserlich, es war ganz innerlich, aus dem tiefsten kommend.“ [„Pa narod je kralju bio vrlo blizak, to je ležalo u njemu, kralju, nije to bilo izvanjski, to je bilo posve iznutra, dolazeći iz onog najdubljega.]- $\mathrm{Na}$ to ja: „Majestät, wenn wir um eine Gnade bei Ihnen bitten dürfen, so wäre dies vor allem, dass Sie, Majestät, auch weiterhin mit dem Volke in der warmen, spontanem Berührung, bleiben, die so ein ausnehmendes persönliches Verhältniss zwischen Volk und König geschaffen hatte." [Veličanstvo, ako nam je dopušteno da kod Vas zamolimo za milost, tada bi to bilo prije svega da Vi, Veličanstvo, i nadalje ostanete u toplom, spontanom dodiru s narodom koji je stvorio tako izniman osobni odnos između naroda i kralja.] - „Aber, ganz bestimmt!“ [„No svakako!“] reče Kraljica odrešito, „das ist ja notwendig, und ist auch für mich ein inneres Bedürfniss, welches ich sowohl hier im Lande als auch in meiner Heimat mir eingeeignet habe. Es ist nicht nur äusserlich“ [,„pa to je neophodno, a i meni je to unutarnja potreba koju sam stekla kako ovdje u zemlji tako i u mom zavičaju. To nije samo izvanjski“"], reče opet, „es kommt aus dem Inneren. Sie sollten sehen wie ich unter dem Landvolk mit offenem Herzen empfangen werde, wie Sie offen und ohne Rückhalt mit mir sprechen. Ja, das haben wir schon ganz jung gelernt. Meine Mutter, wenn wir in den Bergen den Sommer zubrachten, ging täglich mit uns in die Bauernhäuser, und da wurden wir mit dem Leben der Bauern vertraut. Es ereigneten sich dabei auch ganz humoristische Scenen“ [,,to dolazi iz nutrine. Trebali biste vidjeti kako me seosko stanovništvo prima s otvorenim srcem, kako otvoreno i bez zadrške razgovaraju sa mnom. Da, to smo naučili još zamalena. Moja je majka, kada smo ljeto provodili u brdima, svaki dan s nama odlazila u seoske kuće i tada smo upoznali život seljaka. Pritom su se dešavala i vrlo smiješne scene"]. Tu predje Kraljica opet na hrvatski jezik. „Bile su na primjer dvije sestre, dvije stare djevojke, koje su živjele zajedno, ali su se uvijek svadjale. I tu je moja majka morala dnevno suditi. Jedna je govorila „ona je kriva“, a druga je vikala „kad je ona zla“ - a moja mati je imala puno muke s njima. Jedamput su kasno u večer poslali po moju majku, jer je svadja bila tako oštra da ih nitko nije mogao umiriti." Nasmiješi se nekud sjetno toj uspomeni iz bezbrižnih dana, a onda nastavi - „A jednog dana dogodi se u istom selu neko umorstvo. Ubijen bje neki seljak. Moja majka dodje tog dana k ovim dvim sestrama. 
„Pravo mu je da je ubijen“, reče jedna od sestara. „Bio je zločest, pravo mu je“ „Ali to nije niti lijepo, niti kršćanski da tako govorite. Ne smije se ubiti čovjeka.“ „Lako je Vama govoriti“, reče ona mojoj majci, „Vama je dobro a i Vi ne znate kako su ljudi zločesti.- A drugi dan je tim sestrama umrla (kraljica ne reče „poginula“ nego „umrla“) krava - onda su plakale dan i noć.“ Kraljica završiv ovo pričanje reče: „Dakle sam ja već od prve mladosti naučna sa narodom biti“.-- „Vaše Veličanstvo," rekoh, ,sa najvećom radošću slušam kako dobro govorite naš jezik“. - „O da“, reče Kraljica, „to je i moja velika radost. Sad ide sasvim lako. Ali sam cijelih devet godina imala mnogo poteškoća“ i nasmije se tom dugom roku.- Moje knjige, uvezane u kožu sa zlatom i sa slikama: mladog Kralja na „Čudnovate zgode šegrta Hlapića“, kraljevića Tomislava na „ک̌́kola i praznici“, Kraljevića Andreja na „Valjani i nevaljani“ i osim toga bielom kožom i zlatnom ornamentikom za Kraljicu „Priče iz Davnine“ (4 knjige u bijeloj crvenoj i modroj koži sa narodim radom urešene) ležale su kraj nas na stolu.-, ,Vaše Veličanstvo“, rekoh, ,,gospodja Švrljuga bila je tako ljubezna te me obavijestila, da smijem Vašem Veličanstvu ponijeti ove knjige“. „Jest“, reče Kraljica, ,ali mi se čini da ste želili[sic] da ih osobno predate Kralju Petru?" Bila sam zaista iznenadjena i obradovana tim pitanjem, jer sam dakako želila da našeg malog Kralja, na kojemu i u kojemu počiva toliko naših misli, nada i bojazni, vidim.- Kraljica je očito opazila to moje radosno iznenadjenje, jer se je vanredno toplo i gotovo nekim sjajem nasmiješila, kad sam ja nešto odviše gorljivo upala u riječ: „O dakako, da bih to želila!“.- Na to ustane Kraljica iz svog dubokog naslonjača i ja istodobno ustanem, a ona podje hitrim korakom do vratiju, što su bila na desno od vratiju, koja vode u predsoblje. Otvori vrata i zovne: „Petre, dodji!“- Teško je posve objektivno pogledati na dijete, koje je medju mnogim milijunima djece tako iznimnom, tako teškom i tako važnom sudbinom opterećeno, tim više što kod inteligentnog djeteta od jedanaest godina takova sudbina već posve svijesno djeluje na nutrinju, a prema tome i na vanjski stav. Mali Kralj Petar unišao je i ozbiljan i prijazan u isti mah, miran i sabran naklonio se i pružio ruku, koju sam prihvatila sa tolikim osjećajem topline da su mi i nehotice došle riječi, koje sam prema Kraljici izrekla: „Naše dijete i naš Kralj!“ Kraljica ganuta, metnula je ruku oko ramena djetetu. Privela ga zatim k stolu i rekla: „Evo gospodja Ti je donijela ove knjige“.- „Da, Vaše Veličanstvo, ali se bojim da ste Vi prerasli preko tih knjiga. One su bile odredjene da Vam lanjske godine budu predane, no nije tada došlo do moje audijencije.“ „O da,“ reče Kraljica, ,ja sam vrlo požalila da je naš program onaj puta bio toliko promijenjen“. Kralj Petar pregledavao je medjutim knjige i slike na njima. „Ovo je za Vas, Vaše Veličanstvo, a ovo za male Kraljeviće. Na svakoj knjizi ima slika onoga kojemu pripada, da ne bi bilo zabune“. Kralj Petar se nasmiješi, no ne reče ništa. „Vidila sam Vaše Veličanstvo slikanoga na konju. Kako 
se zove Vaš konj?" U taj tren Kraljica, koja je neprestano toplim pogledom gledala sinka reče posmjehom: „Zar ste ovoga dječaka vidili na konju? Zar ovoga?“ i uhvati ga obim rukama za lišce i čvrsto ga potrepta na oba obraza. - mali Kralj, očito iznenadjen tim obratom situacije digne nasmijano lice $\mathrm{k}$ majci, a onda se na čas privine glavu uz nju. - Meni, dakako, val topline prodje i dušom i srcem.- No audijencija je audijencija, a mali Kralj, koji očito potpuno svjestan svojih sadanjih dužnosti, odgovori čas zatim na moje riječi o konju: „Ne znam koji je“, reče i pogleda majku, „Labud?“-,„Nije bijel“, rekoh, ,,nego mrk“. „Možda Jabučar“ (čini mi se da tako reče.) Vratismo se na knjige. „Možda će Vaše Veličanstvo ipak zanimati ova knjiga o Hlapiću“, rekoh ja."To je priča o malom postolarskom šegrtu koji je utekao od svog majstora i na svome putu svašta proživio." Oči mladog Kralja sinuše i kimnu živo glavom kao da kaže „to je ono pravo“ i vidila sam da bi za njegovo djetinje srce audijencija dobila najljepši oblik da sam mu mogla pričati cijelu priču o malom postolaru. No Kraljevi i pjesnici podpadaju teškim i bolnim ograničenjima.- „Dakle, Petre, ovo dobiva Tomy a ovo Andi (mislim da ovako reče Kraljica), a ovo je Tvoje“. - [,]Ja mislim da bi sada Njegovo Veličanstvo mogao već čitati ovu moju knjigu“, rekoh i pokazah na moje „Priče iz Davnine“ koje je Kraljica držala u rukama.- „O da!“ reče Kraljica toplo, „ovo moraš čitati.“ Na to reče: „Idi, Petre, sada“. „On mora da uči!“ - obrati se na mene Kraljica. - Kralj Petar pruži mi ponovo ruku, uze sve tri knjige i ode u svoju sobu. Gledala sam za njim. Dijete vanredno dobrog stasa, tamno-plave kose, crnih očiju, vanredno finog, nešto blijedog lica. Obučen športski: kratke sive hlače, bijeli pulover, čarape do ispod koljena, čvrste cipele - a ujedno čvrst korak i nastup. - Dok je Kralj Petar bio s nama, stojale[sic] smo Kraljica i ja - nakon njegovog izlaska ponudi mi Kraljica da opet sjednem. „Da, Kralj je dobro i poslušno dijete“, reče ona zamišljeno. „Veličanstvo, vidila sam sada i osjetila onaj dio Vašega života, koji Vas je toliko zbližio našem srcu i kojega smo svi osjećali, ako ga i nismo iz bliza vidili.“„Obiteljski je život za nas zaista bio ono najdraže“, reče Kraljica sa suzama.- „Pače, Veličanstvo, ako smijem kazati, imali smo dojam da je ta toplina i taj način upravo gradjanski. Das Bürgerliche, wenn ich mich so ausdrücken darf, war dasjenige, was uns an Sie so nahe gebracht hat.“-, Jawohl, das Bürgerliche - es war in mir und in dem Könige gelegen dass wir darin unsere ganze Freunde und Erholung suchten. Vielleicht wurde es sogar nicht immer gebilligt, es entsprach aber unserer Seele.“„Wenn ich das letzte Bild betrachte, wo Majestät mit König Aleksander im Parke auf Streckstühlen sitzen und wenn ich mir jetzt den friedlichen, - freundlichen Gesichtausdruck und die wunderbar stille Stimmung des Bildes vergegenwärtige so sehe ich was für ein unermesslicher Segen für Seine Majestät diese bürgerlichen Ruhepausen waren.” [„Ono građansko, ako se smijem tako izraziti, bilo je ono što 
nas je Vama toliko približilo.“ - „Da, ono građansko - ono je ležalo u meni i kralju tako da smo u njemu tražili svu našu radost i odmor. Možda se čak nije uvijek odobravalo, no ono je odgovaralo našoj duši.“- „Kada promatram posljednju sliku, na kojoj, Veličanstvo, sjedite s kraljem Aleksandrom u parku na ljuljačci i kada si sada predočim mirni,-- prijazni izraz lica i čudesno tiho raspoloženje slike, tada vidim kakav su neizmjeran blagoslov za Vaše Veličanstvo bile te pauze građanskog mira."]- Ganuta, prinese Kraljica ruku k očima. Požalih što sam i opet taknula ranu, no nismo ni sami još gospodari naših bolnih osjećaja pa nam se misli vraćaju uvijek na jedno te isto.- „Gewiss! gewiss!“ [,Svakako! svakako!“] reče i ostade časkom tako rukom pred očima. A zatim: „Ich darf Sie aber wirklich nicht länger aufhalten, und auch ich habe heute noch weitere Pflichten.“ [,No doista Vas više ne smijem duže zadržavati, a i ja danas još imam daljnjih obaveza."] - Ustadosmo istodobno, te mi Kraljica pruži ruku izrazom i smiješkom, koji je bio mnogo „bliži“ nego onaj kod mog nastupa; a moja oprosna „réverénce“ [smjernost] imala je više duše i više uvjerenja, nego ona nastupna. - Riječju, moj Zdenek, bila sam radosna, jer je naša Kraljica učinila na mene i kao Kraljica i kao dama i kao majka lijepi, ugodni i što je glavno, vrlo ,vertrauenerweckend“ dojam [koji ulijeva povjerenje], a baš ovo posljednje jest ono što sam sa strepnjom očekivala ili ne očekivala. Izašla sam u predsoblje radosna i puna svakojakih misli o daljnjem razvoju povijesti,--sa više nade i poleta nego prije pola sata. Gdja. Švrljuga, koja me dočekala upravo ganutljivo pitajući i sjajnim pogledom, mogla je sigurno na mom licu vidjeti da je audijencija bila „a success“ [uspjeh]. A za mene nova duševna senzacija: ta brižna i topla ljubav „starije sestre“ koju Švrljugica očito goji za našu Kraljicu.- Opazila sam već i prije da ta ljubav nipošto nije službena, a niti namještena il glumljena, ali Ti nemogu reći kako sam u taj čas opazila iskrenosti i brižljivost te ljubavi, kad smo se Dvorska gospodja i ja pogledom sporazumile: „Izvrsno!“- pošle smo u brio tempu niz skaline.- Dolje u hallu baš je Kosta javio Željku da je Željko na redu. Izmijenili smo Željko i ja nekoliko riječi i on odmah podje Kraljici. - Kad sam poslije pod vodstvom Koste, razgledala Dvor, susrela sam Darka na stubama. Išao je u audijenciju rumunjskoj Kraljici, koja je takodjer na Dedinju.- Poslije toga je Darko odmah išao u audijenciju našoj Kraljici i Kralju Petru. - Znam da Ti baš nisi prijateljica patetičnih riječi ni misli, no dani su zaista takovi da donose patetične misli.- Pomislila sam u hallu ovog kraljevskog dvora da je dobar omen [znak], a možda i omen dobre i obostrane mudrosti i ispravnosti, što se u teške dane našlo sve troje „braće“ Mažuranića tako iznenada na Dedinju.-

Ovom vidovitom opaskom, koju će ako dragi Bog da neki pozni praunuk proglasiti istinitom, završujem za danas.- U budućem pismu opisat ću Ti ljepotu, ukusnost $\mathrm{i}$ harmoniju Kraljevskog Dvora Dedinje, koje ne umara ni oči ni dušu veličinom, a 
djeluje svojom finoćom i skladom neobično toplo.-

Grlim Te, dijete moje!

Tvoja

mama.

19. XI. Beograd.

Arhiv obitelji Brlić, kutija inv. br. 76. svežnjić 12.

29. studenoga 1934.

Dr. L. Jacobi

advokat

Dr. L. Rotter

advokat

Zagreb, 29. XI. 1934.

Milostiva gospodjo,

evo novosti. Upravo mi javlja Albini, da je pred 8 dana na Narodnom Divadlu u Pragu bila premijera Vašeg Hlapića u obradbi Strozzijevoj, što je saznao iz Narodnih Listy. Navodno su bile do sad dvije predstave, pa je Albini već pisao u Prag tražeći da mu se pripošalju kritike i obračun. Čim saznam daljnje vijesti ja ću Vam ih saopćiti.-

Nadalje mi Albini saopćuje, da je UJDA prihvatila Vaše pr[ij]edloge glede začlanjenja, pa ćete ovih dana primiti pristupnicu, radi potpisa.-

Sa filmom za sada stvar ne ide, no ne ćemo gubiti strpljenja, jer u toj stvari treba vremena. Albini korespondirao je medjutim i sa g. Basielichem iz Katowica, koji se na Vas bio obratio radi Hlapića. Ovaj gospodin javlja prema navodu Albinia, da je za sada u Poljskoj za naše autore interes veoma slab, nadam se da će s vremenom i iz toga nešto biti.-

Primite, milostiva gospodjo, i ovom zgodom izraz moga velikog poštovanja.

Vaš odani

Dr. Rotter

Arhiv obitelji Brlić, kutija inv. br. 81, svežnjić 5 .

9. prosinca 1934 .

Katowice, 9/XII 1934

Visoko Poštovana Gospođo!

Napokon štampan je moj informativni skroman članak o Vama u Krakovskom dnevnom listu „Ilustrowany Kuryer Codzienny“. To je naš najveći list. Nažalost 
uskratili[sic] su ga s nekih 60-70 redaka, gdje sam citirao Vaše riječi o postanku „Priče iz davnine“. Ilustracije, koje ste mi izvoljeli doslati[sic], propale su u redakciji „Bluszcza“ (Blušča), revije za žene, koja je imala ovaj članak da štampa. Zato u „Ilustr. Kuryeru Codz.“ nije ilustriran. Jedan primjerak ovog lista šaljem Vam u posebnom omotu.

Izvinite, da nisam Vam do sad odgovorio na Vaše zadnje pismo od 21/V o. g. Primio sam je upravo, kad sam organizirao ekskurziju u Jugoslaviju za članove ovdašnjeg Poljsko-Jugoslovenskog Društva, pa tom prilikom bio sam opterećen, da nizašto nisam imao vremena. Poslje pošao sam i sam u Jugoslaviju, a kad sam se vratio, početkom novembra, zatekli su me mnogi službeni i drugi poslovi i opet nije bilo vremena za druge stvari.

Glede honorara od pozorišnih komada isti je uzus i kod nas, naime od svake predstave odpada piscu $14 \%$ - 18\% brutto dohodka. Za moj dijel lako bismo se sporazumjeli, jer diobu ostavljam Vama. Ali najprije treba, da pročitam i upoznam tog „Hlapića“, zato molim Vas, da mi izvolite poslati jedan primjerak, ako samo želite, da ga prevedem. Ako stvar je interesantna, a inscenizacija[sic] nije previše skupa, mislim, da bi imala uspjeha i kod nas. Nastojao bih, da ju uzmu u Varšavi, Poznanju, Lavovu, Krakovu i Katovicama.

Svakako rezerviram si slobodno vreme za prevađanje Vašega „Hlapića“ za mjesec siječanj i veljača te slobodan sam moliti Vas za ljubezni odgovor po mogućnosti još prije Božića, a rukopis mogli bi mi doslati oko Nove Godine.

Zasad dozvoljavam si želiti Vam najmilije Božićne Blagdane i sretnu Novu Godinu, te šaljem izraze odličnog poštovanja

[nečitak potpis, vjerojatno Wiktor Basielich]

Arhiv obitelji Brlić, kutija inv. br. 81, svežnjić 5.

15. prosinca 1934.

Dr. L. Jacobi

advokat

Dr. L. Rotter

advokat

Zagreb, 15. XII. 1934.

Milostiva gospodjo,

Hvala Vam za pismo od 1. o. mj. Ja sam kod g. Verlia dao intervenirati, da bi se pred Božić davao Hlapić, ali se bojim, da ne će biti uspjeha, jer će - kako ste sigurno iz novina razabrali - doskora ići dječji novi komad od gospodje KolarićKišur s Malom[sic] Leom. -

Medjutim je Albini iz Praga primio obavijesti od svoje tamošnje veze, da je 
komad u Pragu plasirao Lovrić. On je opet pisao u Prag tražeći razjašnjenje, jer je nejasno, da li je Hlapić išao u obradbi Strozijevoj ili možda kojoj drugoj. Uputio sam Albinia, da protestira protiv toga, da se komad daje bez predhodne dozvole autorice ili zastupnika i da već zato ne možemo prihvatiti od uprave tamošnjeg teatra ponudjenih $3 \%$ od bruto prihoda, već tražimo bar $6 \%$.-

G. Albini obećao je, da će još danas pisati te uz razjašnjenja tražiti i obračun.-

Što se tiče filma tu za sada nema novosti. Basielich se više nije javio, tek je prije već pisao, da za sada nema interesa za jugoslavenske sujete za film.-

Direktor Reichl iz Praga takodjer se nije javio, a ni iz Amerike od MetroGoldwina, kamo je Albini poslao jedan primjerak Hlapića, nema odgovora.-

Čim bude novosti, ja ću Vam se i opet javiti.

Primite, milostiva gospodjo, i ovom zgodom, izraz moga velikog poštovanja i srdačne pozdrave.-

[rukom pisano:] odani Vaš

Leo Jacobi

Arhiv obitelji Brlić, kutija inv. br. 81, svežnjić 5

16. siječnja 1935.

Dr. L. Jacobi

advokat

Dr. L. Rotter

advokat

Zagreb, 16. 1. 1935.

Mnogo poštovana milostiva gospodjo,

$\mathrm{Na}$ Vaš c. upit od 9. o. mj. odgovaram tek danas, jer sam istom danas primio od g. Albinia pismo Universuma od 17. 12. pr. g., koje Vam pod ./. šaljem u originalu na uvid i molim, da mi to pismo po uvidu izvolite povratiti. [Rukom upisano na margini: vratila]. Kako vidite cijela tantijema za Hlapića iznosila je do tada Čk. 125.90, a kako me Albini uvjerava, nije se moglo više postići. Komad navodno u Pragu više ne ide. -

Što se tiče obradbe, to je prema saopćenju g. Albinia praški režiser g. Port sam priredio češku versiju za pozornicu i to prema manuskriptu g. Strozzia i to posredovanjem g. Lovrića.-

Imate li vijesti od g. Basielicha?

Čim od g. Albinia primim obračun i novac javit ću Vam se opet.-

Primite, milostiva gospodjo, i ovom zgodom izraz mog velikog poštovanja.

Leo Jacobi

Arhiv obitelji Brlić, kutija inv. br. 81, svežnjić 5. 


\section{5. siječnja 1935.}

\section{Poštovana gospođo!}

Prije par dana primio sam Vašu knjigu o Hlapiću, na kojoj se Vam zahvaljujem. Pročitah ju odmah, te latit ću se prevođenja kad samo ozdravim od gripe od koje bolujem već po drugi put u ovoj godini. Ova pripov[i]jetka vrlo se sviđa mojoj 6-godišnjoj ćerčici[sic], kojoj pripov[i]jedao sam početak i prvi dan putovanja. Želi da što prije ustanem iz kreveta i prevedem cijelu pripov[i]jetku, pa da ju joj posle pročitam. Mislim dakle, da sviđat će se i drugim djecima[sic].

Češki prevod ne trebam, jer i slabo znam češki.

Primite izraze mog osobitog poštovanja i srdačne pozdrave

[nečitljiv potpis, vjerojatno Wiktor Basielich]

Arhiv obitelji Brlić, kutija inv. br. 81, svežnjić 5.

\section{5. siječnja 1935.}

UJDA

UDRUŽENJE JUGOSLAVENSKIH DRAMSKIH AUTORA SOCIÉTÉ YOUGOSLAVE DES AUTEURS DRAMATIQUES Generalni zastupnik ALBINI Agent générale dne 25. januara 1935

\section{„ČUVAT ĆEMO JUGOSLAVIJU“}

Gospodin

Dr. L. Rotter

odvjetnik,

$\underline{Z a g r e b}$

Amruševa ul. 13/I

Mnogopoštovani gospodin Doktore!

Potvrdjujem primitak Vašeg cij. dopisa od 21. o. mj. u predmetu „ŠEGRT HLAPIĆ“" gospodje Brlić-Mažuranićeve, te mi je čast obavijestiti Vas, da doznaka tantijema još nije usl[i]jedila, ali da mi je stavljena u izgled za početak februara o. g.

Istodobno sam slobodan priposlati pristupnicu UJDA sa molbom, da je mil. gdja Mažuranić potpiše. Njene rezerve su prihvaćene.

Radi filmskog plasmana pisao sam danas ponovno A. B. Filmu u Praha, te ću Vas obavijestiti o odgovoru.

Molim, da i ovom prilikom primite izraz osobitog veleštovanja

\section{Albini}

Arhiv obitelji Brlić, kutija inv. br. 81, svežnjić 5 . 


\section{9. veljače 1935 .}

dr L. Jacobi

advokat

dr. L. Rotter

advokat

Zagreb, 9. II. 1935.

Milostiva gospodjo,

Primio sam Vaš c. dopis od 5. o. mj., koji uzimam na znanje, te se radujem, da ću Vas moći doskora u Zagrebu pozdraviti, pa će tad biti i prilike da sve dogovorimo.

$\mathrm{Na}$ Vaš upit da li imamo kakav ugovor s Albinijem obzirom na budući prijevod „Hlapića“ po Basielich-u odgovaram, da Albini imade zastupstvo za pravo prijevoda za one zemlje u kojima ne postoji prijevod u času kad je ugovor bio sačinjen. Medjutim, obzirom na to, da će do tog prevoda doći bez zauzimanja g. Albinia, to s njim, vjerujem, ne će biti teškoća.-

Ivo predao mi je jedan primjerak poziva priredjivača reprezentativne izložbe Jugoslavenske knjige u Pragu, koji prilažem pod ./., da uzmognete odboru priposlati ono što traži.-

Primite i ovom zgodom izraz moga odličnoga poštovanja.

$$
\text { Leo Jacobi }
$$

[nadopisano rukom: Odg. 9/III da nepristupam u Udr. Dram

Da hvala za predlož. interv. kod cenzure, no bolje da zapljena ostane]

Arhiv obitelji Brlić, kutija inv. br. 81, svežnjić 5. 


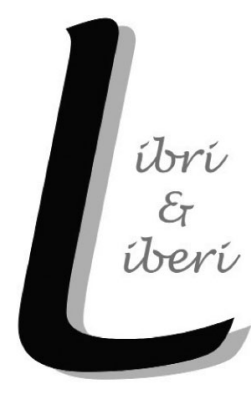

\section{Prikazi \\ Reviews}





\section{Enchanted and Erudite}

\section{Marina Warner. 2012. Stranger Magic: Charmed States \& the Arabian Nights.} London: Vintage, 540 pp. ISBN 978-0-099-43769-7

Using nothing but superlatives to describe the works of Marina Warner has by now become an almost automatic response from reviewers and readers alike. The renowned novelist, critic, cultural historian, university professor and CBE has, in a sense, spoiled us with her intellectually and - given the numerous colour plates and illustrations - visually stimulating, yet accessible and highly readable books, covering a wide range of topics such as the Virgin Mary (Alone of All Her Sex: The Myth and the Cult of the Virgin Mary, 1976), fairy tales and nursery rhymes (From the Beast to the Blonde: On Fairy Tales and Their Tellers, 1994), representations of fear (No Go the Bogeyman: Scaring, Lulling, and Making Mock, 1998), etc.

Stranger Magic (2012), Warner's most recent publication, is an extensive study of Alf Layla wa-Layla or the Arabian Nights (also known as the Arabian Nights' Entertainment, Tales of a Thousand and One Nights, or simply the Nights), one of the most famous and perhaps most mysterious collections of tales. The supposed mystery of this (as Warner calls it) "polyvocal anthology of world myths, fables and fairy tales" (8) stems to a large extent from its diversity and - for lack of a better term - elusiveness. Not only is the time and place of origin of the Nights unknown, but both the tales and the collection seem to lack a stable, definitive shape, existing in a state of flux, in innumerable versions, translations and adaptations.

The main issue that prompted Warner to study the Arabian Nights was the fact that the collection was first presented to European audiences in "the most contradictory possible time" (20): the period of Enlightenment. French translations by Antoine Galland (1704-17; also the first printed versions of the collection) were immensely successful, giving rise to an 'oriental craze' - a fascination with everything Arabic, fabulous and magical. How and why, Warner wonders, did an age obsessed with reason, logic and rationality embrace a collection of decidedly irrational and wondrous tales? Escapism may seem like an obvious answer, but it does not satisfy the author, who studiously uncovers layer after layer of stories, influences and narrative traditions, spinning - much like Shahrazad (Warner adopts the modern transliteration) - her own complex, rich and intriguing tale.

The mention of Shahrazad here is no coincidence: in many ways, Stranger Magic takes on the attributes of the subject of its study. Not only is the narrative itself layered, intertwined and rich in detail, it also includes 'tales-within-tales': Warner's own retellings of fifteen (less known) tales from the Nights. If the Arabian Nights are characterized by diversity and plenitude, so is Warner's book: the erudite author uses the 'frame narrative' of a scholarly study of the Nights to include analyses, musings and discussions of a wide range of topics, from Dante to Darth Vader; from the talismanic value of money to the living quarters of Mikhail Bulgakov; from dervishes and talking toys to stage machinery and special effects on film. The discourse itself is enchanting and ever-changing, at times taking on an objective, scholarly note, at times relating childhood memories and personal 
experiences in a more reflective and subjective fashion. The book is a proverbial cave of wonders, filled with stimulating and interesting arguments, well-researched data and even curiosities such as the fourteenth-century legal treatise discussing marriage between humans and jinn.

In addition to inspiring delight and wonder, the Nights have also, to an extent, fostered prejudice and promoted stereotypes about the so-called Orient. Namely, numerous readers and translators (most notoriously Edward Lane) believed the Nights were a mirror image of the Arab world (the aforementioned Lane added ethnographic annotations to his nineteenthcentury translation). On the other hand, the tales in the collection embodied the West's romantic notion of 'Araby' as the exotic and magical site of exquisite pleasures. Such views have often been criticised, perhaps most severely (and certainly most famously) by Edward Said, whose postcolonial criticism constitutes one of the theoretical cornerstones of Warner's book.

Stranger Magic is divided into five parts, complemented by the previously mentioned retellings of select tales from the Arabian Nights, an introduction and conclusion, an extensive bibliography, a glossary, more than 50 pages of notes, 25 five colour plates and numerous illustrations in the text. The first part of the book uses the enigmatic figure of Solomon to discuss two (perhaps most readily recognizable) motifs from the Arabian Nights: the jinn (Solomon as the master of jinn) and the flying carpet (in some traditions Solomon's means of transportation). Part two, "Dark Arts; Strange Gods" discusses dark, 'exotic' magicians and the tendency to ascribe forbidden, supernatural powers to strangers and outsiders in general (in the Arabian Nights, Egyptians are most often cast in the role of the 'Other'). Part three is dedicated to the study of what Warner terms the "thing-world of the Arabian Nights" (195). The tales in the collection are, claims Warner, essentially about property, artefacts and material objects (lamps, rugs, bottles and flasks, talismans and amulets, automatons...), which are often infused with supernatural abilities and/or human properties.

The final two parts of the book are dedicated to the afterlife of the Nights - the responses of writers and other artists to the book and its various media appropriations. Part four, "Oriental Masquerades", includes chapters dedicated to Anthony Hamilton, William Beckford and Goethe. Part five, "Flights of Reason", mostly deals with screen versions of tales from the Arabian Nights (especially the two versions of "The Thief of Bagdad" and the shadow films of the almost forgotten film-maker and puppeteer Lotte Reiniger) and the representation of magic on film in general. The chapter "Why Aladdin?" inquires into the appeal of this particular tale (which, though often regarded as one of the 'most Arab' in the collection, was probably penned by Galland himself), pointing to "multiplicity and mobility" (361) as the key to its success. The final chapter takes a look at the oriental rug which covered the famous couch on which Freud's patients would lie during their sessions. The choice of the rug is perhaps not accidental (after all, as Warner reminds us, "[n]othing was accidental for Freud in the psychopathology of everyday life" (411)), as both the Arabian Nights and psychoanalysis rely on storytelling (though unlike the Nights in which Shahrazad's tales eventually transform and heal her husband, in psychoanalysis it is the teller and not the listener who needs to be healed). 
In her introduction, Warner honours Robert Irwin and his Arabian Nights: A Companion (1994), claiming that without his work her own book would not have been possible. There is little doubt that future generations of scholars will pay tribute to Stranger Magic, mentioning with equal admiration and gratitude how inspiring and indispensible they have found it.

Nada Kujundžić

\section{Playing as a Serious Task}

\section{Cherie Allan. 2012. Playing with Picturebooks: Postmodernism and the Postmodernesque. Hampshire: Palgrave Macmillan. 201 pp. ISBN 978-0-230-} 22786-6

Cherie Allan's Playing with Picturebooks: Postmodernism and the Postmodernesque is a book in the Critical Approaches to Children's Literature series which publishes selected contemporary scholarship and criticism on children's and young adult literature, film and media texts. The aim of the series is to provide quality books that will stimulate further research of children's literature.

In her book, Allan deals with the ways in which postmodernism has influenced picturebooks. She discusses the recent shifts in this exciting genre and explains the coining of the term 'postmodernesque', in analogy with Mikhail Bakhtin's term 'carnivalesque'. She claims that, "[J]ust as elements of the carnivalesque were carried over into literature, postmodernesque picturebooks have emerged from the postmodern tradition and yet exhibit a sufficient shift in direction to warrant a separate designation" (24).

This study focuses in an innovative and resourceful way on the theoretical foundations needed to understand trends in recent picturebook production and on the modifications of the genre in general. The study is of high significance in the field of children's literature research and will benefit not only academics in the field of children's literature, but also teachers and students, whether to introduce them to the topic or to give a fresh perspective and encourage further debate.

Allan uses a wide range of internationally known picturebooks to support her argumentation. She also references plenty of well-known experts in the field, and their works. Has postmodernism improved the development of picturebooks, or has it made way for the consumerist lifestyle? Is postmodernism still influencing modern picturebooks, or have they gone beyond postmodernism, converting to the postmodernesque? These are some of the questions Cherie Allan asks in this book.

In the introduction, the author looks back at the origins of postmodernism, which has always been a subject of debate. The difficulty in understanding the term is largely due to the media using it overly lightly. The author proceeds by outlining the features of postmodernism. Picturebooks are described as "cultural texts which reflect the tenor of their times" (2) and, "with their dual codes of written and visual texts, are ideally located to appeal to a postmodern audience" (4). Towards the end of the introduction, Allan questions the appropriacy of the term 'post-postmodernism' used by some scholars to refer to new 
literary conventions emerging as the influence of postmodernism declines. She proposes the term postmodernesque to refer to picturebooks written at the beginning of the twentyfirst century that use some metafictive strategies but that also question the aspects of postmodernity.

The first chapter is entitled "Looking Beneath the Surface". Allan starts the chapter with Molly Travis's statement that postmodern texts show us they are not "natural, finished and seamless", but rather "constructed, open, fragmented and plural" (27). They can be described thus since they lay bare the conventions of a classic realist text through the usage of various metacognitive strategies. Allan discusses these strategies, such as intertextuality, parody (especially the parody of fairy tales), frame-breaking and metalepsis by using focus picturebooks as examples. The second part of the chapter examines three picturebooks more closely: Voices in the Park by Anthony Browne, Three Pigs by David Wiesner and The Stinky Cheese Man and Other Fairly Stupid Tales by Jon Scieszka and Lane Smith. The author argues that while the first two texts do employ various metacognitive strategies, they also display liberal humanism and its conventions. On the other hand, The Stinky Cheese Man and Other Fairly Stupid Tales resists those conventions, and is thus, as David Lewis also claimed in 2001, the only "true" postmodern picturebook (at the time).

In the second chapter, Allan takes a further step in examining various metafictive strategies found in postmodern picturebooks, with an emphasis on representation and how this is placed in the foreground. As with the previously noted strategies, the postmodern picturebook uses intertextuality, indeterminacy and polyphony to "lay bare" the established conventions, and in this way presents itself as a representation or a construct to its readers. Allan quotes Jean Baudrillard's thought that the image has become more important than the depicted reality and points out that we live in a hyperrealist, media-dominated world. Focus picturebooks are used to illustrate this uncertainty by drawing attention to the arbitrariness of language (as in the above-mentioned The Three Pigs and in The Red Tree by Shaun Tan), the use of invented languages (visible in Baloney (Henry P.) by Jon Scieszka and Lane Smith), the use of frame-breaking (in Black and White by David Macaulay), mise-en-abyme (in Zoom by Istvan Banyai) and the notion of the instability of identity (The Stinky Cheese Man and Other Fairly Stupid Tales).

The next chapter focuses on the ways in which reality is represented in postmodern picturebooks. Allan examines how the boundaries between fictional worlds are crossed in a number of focus texts. A rabbit enters the world of grey wolves by being immersed in a book about them in Wolves by Emily Gravett. Because of this, "the ontological status of the wolf in relation to the rabbit changes from construct to 'real' and thus enables it, at that level, to pose a real threat to the rabbit" (83-84). In Wait! No paint! by Bruce Whatley, a parody of the traditional tale about the three little pigs, an intrusive illustrator helps the characters to become aware of their status as fictional characters. Such processes which push back the boundaries between narrative worlds, or between fictional and real worlds, show the ways in which postmodernism seeks to refuse to accept certainty or any absolute truth. As Allan states, "In questioning the conventional belief that narratives reflect the 'real' world, postmodern picturebooks draw attention to the fictional process of storytelling, the fictional world as construct and the text as artifact" (80). 
The fourth chapter presents historiographic metafiction as a genre that has emerged from postmodern fiction. It reinforces the multiplicity of histories by denying history the 'right' to present only one truth. Picturebooks that belong to this genre show a special playfulness, although they often deal with serious topics. For instance, in Memorial, the authors Gary Crew and Shaun Tan deal with the unreliability of memory presented in a story about a boy who listens to older members of his family tell him about the past. The British settlement of Australia is described in The Rabbits by John Marsden and Shaun Tan through an allegorical story of marsupials whose peaceful life is greatly disturbed by the arrival of the rabbits. In a very interesting way, Allan highlights some details from the book which show that, although the aim of the book is to present the Aboriginal people's view of history, the authors unintentionally reinforce some common prejudice and misconceptions. Other picturebooks examined include A Coyote Columbus Story by King and Monkman, an alternative view of the discovery of America, and The Discovery of Dragons by Graeme Base, which parodies the Age of Discovery. The author finally presents The True Story of the 3 Little Pigs!, yet another picturebook by Scieszka and Smith, as an example of fictional historiographic metafiction in which the protagonist Alexander $\mathrm{T}$. Wolf (or Al, for short) takes his chance in convincing the readers that he is as innocent as a lamb.

The fifth chapter gives a postmodern view on the imposed unity and conformity found in liberal humanist discourses. Such practices are questioned with the celebrating of marginalized individuals. As Allan states, postmodern picturebooks deal with a variety of characters "who suffer social exclusion, live on the margins of society, are alienated by difference, or work to be accepted by the dominant society" (124). She gives examples of such characters found in several focus picturebooks by Toby Riddle. Four animals escape from the zoo and try to blend into society in The Great Escape from City Zoo, and the fox and the donkey from Nobody Owns the Moon have a similar desire. Colin Jenkins, once a successful businessman, finds himself rejected by society when he wakes up one day with a bird's nest on his head and decides to leave it there, in The Singing Hat.

The notions of ex-centricity and difference, as Allan claims, "have contributed to a growing trend whereby various fields are achieving autonomy from the label postmodernism by creating their own discourses" (139). The author examines the shifts that postmodern fiction experiences in the last chapter of the book entitled "Towards a Postmodernesque Picturebook". Postmodernism, as all literary trends eventually do, has reached a point of exhaustion. Allan argues that the main difference between postmodern and postmodernesque picturebooks is that while the first question the features of liberal humanism, the latter "turn their attention to the critique of the postmodern world: a globalised, mediated, hyperreal world in which, seemingly, the only way to make any sense of it is through the rampant consumption of goods, services and signs, and in which individuals construct multiple identities and learn to navigate through multiple realities" (141). It could be said that the postmodernesque picturebook is a picturebook about postmodernism. The author proceeds by examining the aspects of our postmodern world ridiculed in focus picturebooks: globalization and its effects, the influence of the mass media and consumption of goods, services and signs. Often these traces are subtle and can be seen only when reading both verbal and visual texts very closely. The Short and Incredibly Happy Life of Riley by Colin 
Thompson and Amy Lissiat mocks consumerist society, which is visible in the quote from the picturebook that caught our attention: "People want microwave-video-dvd-sms-internetbig-car-cost-more-than-yours [...] electronic-gigabyte-fastest- [...] machines", which, according to Allan, "suggests the haste and excessive desires that characterize the urgency to consume" (166). In The Empty City (by Davis Meggarity and Jonathon Oxlade) and In the City: Our Scrapbook of Souvenirs (by Roland Harvey), readers are drawn into globalized cities where there is a proliferation of choice, while personal interactions with people are minimal, and the notions of time and space are deconstructed. In focus picturebooks, there are clear hints of nostalgia for the simplicity and innocence of the past.

This is one of the paradoxes of postmodern picturebooks, as Allan states in the conclusion. On the one hand, they resist conventional approaches, and, on the other, they adopt them readily. The conclusion of the book offers observations instead of drawing a definitive conclusion, in the manner of the genre which the book examines. The author predicts a bright future for the genre of picturebook, and, after reading this book, we could not agree more. This genre is more exciting today than ever before; it appeals to readers of all ages and offers many possibilities to engage with the texts.

Although the book is written in a strictly scholarly manner and uses sophisticated theoretical concepts, which can make it slightly difficult to understand for students and the general reader, it can still encourage such an audience to maintain its interest in children's literature and picturebooks, as it reveals how complex and exciting they are. Besides, it can trigger interest in those on their verge of entering the realm of theory as novice researchers in pursuing picturebook research and in further exploring various aspects of postmodernism. From the point of view of picturebook scholarship, this book gives a fresh and inspiring perspective on contemporary picturebooks, which will certainly need to be taken into account in future studies in the field.

Mateja Latin and Dina Alexandra Pavković

\section{Robinson as Children's Reading}

\section{Andrew O'Malley. 2012. Children's Literature, Popular Culture, and \\ Robinson Crusoe. Basingstoke and New York: Palgrave Macmillan, xii + 195 pp. ISBN 978-0-230-27270-5}

Launching the series Critical Approaches to Children's Literature, the Australian editors Kerry Mallan and Clare Bradford focus on "new and developing areas of children's literature research as well as [on] bringing contemporary perspectives to historical texts". Andrew O'Malley's latest book dealing with historical reasons for which "Robinson Crusoe has featured most prominently and circulated most widely" (3) in the fields of children's literature and popular culture certainly sheds new light on this classic work.

The book contains an introduction and five chapters (i.e. 158 pages of main text and 40 pages of notes and an index). Although it may seem that others have already said all that needs to be said about Robinson Crusoe, O'Malley's particularly interesting and well argued study brings a fresh perspective to Robinson and gives it new impetus. 
In the introduction, the author sets the framework for his study, drawing on research of the construction of modern childhood presented in his previous book The Making of the Modern Child (2003): in the late eighteenth-century England, elite culture defined itself in opposition to both popular culture and children's culture. The elite and the lettered started to view common people as foreign and exotic and at the same time saw children as different from themselves, as those that had to be "better understood in order to be better managed" (5). Since Robinson Crusoe (1719) is imbued with and deeply marked by the culture both of children and the common people, O'Malley's choice of the novel as the subject of a case study to analyze how these two spheres of culture were formed and how they defined one another comes as no surprise.

The first chapter examines the ways in which Robinson, though written for adults, became a canonical work of children's literature. According to O'Malley, one of the reasons lies in the fact that Robinson corresponds to the pedagogical practices of the $18^{\text {th }}$ and early $19^{\text {th }}$ centuries, as they were explicitly presented in Locke's Some Thoughts Concerning Education (1693) and Rousseau's Emil (1762). Owing to the congruity between Robinson's theme and the aims of concurrent pedagogical practices, the book was widely present in contemporary children's literature, tailored to conform to the pedagogical principles of the time. O'Malley discusses the dominant pedagogical belief that children learn most effectively by example and emulation rather than by learning dry texts by heart. Robinson Crusoe was perfectly aligned with the educational principles promoting learning through direct experience, role-playing or learning through dialogues in which children would discover natural and moral truths by themselves. Comparing three adaptations of Defoe's text, The New Robinson Crusoe (orig. 1779) by Joachim Campe, The Children's Island (1800) by Madame de Genlis and The Young Crusoe (1829) by Barbara Hofland, the author points out the exact places where they depart from the original and thus elucidates the delicate points in Defoe's text that had to be modified in order for the story about Robinson to be turned into successful didactic reading. The main aporia in the approach to Robinson Crusoe is how to reconcile the text that inspires children to run away from authority and seek self-realization with the need to supervise and educate them. O'Malley's study will be particularly interesting for Croatian readers as it provides information about Campe's version of Robinson Crusoe that significantly contributed to the development of Croatian children's literature. Antun Vranić, who translated Campe's Robinson into the kaikavian dialect in 1796, hastened to emphasize in the preface the value of "pelda" (learning by example) as a didactic principle, thus confirming O'Malley's assertion about the links between pedagogy and the story of Robinson, links that were preserved in the Croatian translation as well.

The second chapter is dedicated to an analysis of robinsonades and abridged children's editions of Robinson Crusoe. The examination of the surrounding body of literature stemming from Defoe's original text enables us to analyze Robinson Crusoe not only within the post-colonial framework that considers it a paradigmatic colonial or a "profoundly masculinist" text, but also to perceive its "feminized register of the domestic story" (53) in addition to the obvious adventurous aspect of the story. As O'Malley puts it, the "stay on the island represents the domestic rather than the mercantile aspect of bourgeoisie life" (53). In the early nineteenth century, virtue was moved from the public sphere to the domestic 
sphere, and the home became the basis that made it possible to expand colonization and to impose virtue on the Other, the uncivilized.

In the third chapter, O'Malley examines adaptations of the story about Robinson in chapbook versions. Contrary to theoretical studies that look at chapbook versions as impoverished and reduced narratives of Defoe's original work, O'Malley suggests that we approach them as narratives that correspond precisely to the needs and expectations of their readership. Well-read elite readers identified with the singular experience of the hero, his efforts to survive and his middle-class values of acquisition and accumulation. On the other hand, in often considerably distorted versions of narratives typical of chapbooks, plebeian readers found elements close to the narrow repertoire of themes present in other contemporary chapbook editions and focused mainly on the hero's finding a way out of his predicament by relying exclusively on good fortune and not on hard work and religious devotion. Such adapted chapbook versions found their way to children very easily, which made them potentially subversive. The undesirable link between children's readership and the chapbook is amusingly illustrated by O'Malley's account of the trajectory that a popular poem about Robinson Crusoe took from its first versions in chapbooks to its place in the nursery rhymes repertoire. To conclude, two ways in which Robinson Crusoe reached children are sketched: one is through didactic practices in the eighteenth century, and the other one, less controlled and less desirable, is through often dubious (from the viewpoint of the upper classes) versions in chapbooks.

In the fourth chapter, O'Malley analyzes theatre performances of Robinson Crusoe from the first pantomime in 1781 to today's Christmas pantos. In their beginning, these pantomimes were performed after the evening's main drama or comedy and consisted of two acts: the first act sought to depict faithfully the principal events in the story and the second consisted of a harlequinade. In Robinson Crusoe pantomimes, Friday becomes Harlequin and seduces Columbine. The second act is actually a parody of the first, more serious, act. Common people and children were irresistibly attracted to the world of harlequinades where everything is possible, where the authority of a serious narrative depicted in the first act is easily destroyed by a single motion of Harlequin's magic wand. The definitive taming of irreverent elements of harlequinades and their transformation into a version more suitable for children was completed with the passing of the Theatrical Licensing Act in 1848, when pantomimes were limited to the Christmas season. Therefore, at the start of the Victorian era, the celebration of Christmas underwent a transformation from less desirable holiday-season customs (excessive alcohol consumption, street festivities) into a holiday of the home and family in line with middle-class values. In these Christmas pantomimes of Robinson Crusoe, the hero's fate was "determined by the whims of fairies and elves rather than by his own choices, actions, and faith" (117). In sum, this chapter provides an account of how Robinson Crusoe, corresponding with and participating in social changes, underwent modifications and transformations that spilt over into the areas of popular culture and children's culture.

The fifth chapter examines the presence of the main protagonists of Robinson Crusoe in today's consumer culture, where they are displayed in various goods ranging from souvenirs and plates to computer games. O'Malley examines what kind of notions the selling of goods with Robinson's name attempts to create in the consumer's mind. "While 
the appearance of Crusoe on toys [...] enacts the logic of adult perceptions of childhood, it must be remembered that toys are more than a site on which adults project nostalgic longings for lost childhood" (151). While they can control the production of toys, adults cannot have complete control over children's play and the ways in which these toys are used in play (very often in ways not desired by adult authority).

While reading O'Malley's book, I kept recalling a paragraph from the novel Poletarci [Fledgelings], written by a Croatian children's author Josip Pavičić in 1937. The grandmother talks about her grandson Ilijica and the events that occurred prior to the Great War:

"Once - in an evil moment - he brought some book from his teacher, full of bits and pieces about faraway lands and wild people: a storm battered a ship at sea and all the crew got drowned but for one of them, who somehow managed to survive and came to that wild land and lived there in all manner of ways... My little one read it every day anew, he had read it, I guess, fifty times - I could see that the book did harm: the child would sleep like a log, but when he got dazzled by the book, he started to toss and turn and sigh until a small hour, and when he would finally fall asleep he would talk and yell in sleep. I grabbed the damned book and took it to the teacher, but it was too late: the poison remained in his blood and he was thinking only of how to go to faraway, wild lands when he grew up. And, you see, he grew up and left..."

A little later in the same monologue:

"The teacher told me that the book was written many years ago, and that the man who wrote it died long ago. And you see: the man died but the book remained, went over the world - and even after so many years its evil power was in place..."

Robinson talks about a desire to leave one's own country and set off for remote lands. In the Croatian case this has a paradoxical twist: Robinson's adventures have inspired young readers to satisfy their desire for unknown faraway countries. However, in the Croatian context, seeking to satisfy their desire for faraway places, many young lads, just like Ilijica, ended up in the black holes of mines across the ordered world from which Robinson fled.

Reading O'Malley's attention-grabbing study, Croatian readers will inevitably be inspired to pursue the issues related to their reading experience, informed by the reception of Robinson Crusoe in our culture. The story about Robinson reached Croatian culture via the German transfers of J. H. Campe (in the late 18th century) and O. L. Heubner (in the 19th century). The first abridged versions of Defoe's text in translation were published in the 1920s, when also the first picture books about Robinson appeared. The first longer edition of the book, considerably censored as all the parts of the text containing religious motifs were left out, was published in the series called Pionirska knjižnica [Pioneer Library] in 1954. Heavily censored and ideologically coloured, this edition was, apart from abridged versions, the only existing version up to the 2000s, when the first integral translations of Robinson into Croatian saw the light of day.

As O'Malley's book approaches Robinson Crusoe through its secondary forms, such as pedagogical adaptations, adaptations for children, chapbook versions, theatre performances and its presence in consumer culture, it will probably inspire Croatian researchers of children's literature to explore a particular secondary form that is characteristic of Robinson's presence in Croatian culture. In Croatian literature, the 'Robinsonian theme' was present before the arrival of Robinson, and, even after, its appearance continued to 
enjoy more popularity than Robinson itself. For example, the story of Genoveve exploits the Robinsonian theme in that its heroine leads a solitary life in the wilderness, physically isolated from other people. Genoveve was staged in Croatia as early as 1732, while Campe's Robinson was first published in Croatian in 1796. For another century, Genoveve, translated into Croatian from the German version by Christoph Schmidt, published in 1846, remained the most popular children's book in Croatia.

Genoveve had circulated in France since the mid-seventeenth century, and was extremely popular in the Netherlands and Germany. The theme of the hero's physical isolation from other human beings is present (most probably not only in Croatian literature) in a number of narratives, in some of them amalgamated with another, dominant theme. This prompts us to ask: can we look at robinsonades as much more than literary texts that derive directly from Defoe's text? Can we look at Defoe's text as an offshoot of the ancient theme that has intrigued writers' imagination since ancient times? If so, then the investigation of the circumstance of the popularity of Defoe's work must take into consideration the literary context and the pre-existing interest in this theme among the readership, which was aroused by a number of treatments of this theme prior to Defoe's. The factor of the preparedness of the readership should not be ignored if the pictures we expect to gain are to be satisfying.

This fundamental theme of children's literature has inspired sustained interest among Croatian researchers. Vladoje Dukat, Milan Crnković, Tihomir Engler and others with their studies on the wider context of Robinson Crusoe's presence in Croatia have contributed to the exploration of the beginnings of children's literature in Croatia. O'Malley's book will certainly inspire Croatian researchers to pursue further such research.

Berislav Majhut (translated by Snježana Veselica Majhut)

\section{Brand New Critical Essays on Harry Potter}

\section{Cynthia J. Hallett \& Peggy J. Huey, ed. 2012. J.K. Rowling: Harry Potter. Hampshire: Pelgrave Macmillan. xii+206 pp. ISBN 987-0-230-00850-2}

The New Casebook series is published with the specific goal of providing readers, primarily students, with fresh thinking about already familiar and widely discussed texts and writers, in addition to encouraging them to extend their original ideas and responses to literary texts. In one of the recent books, Cynthia J. Hallett and Peggy J. Huey gathered thirteen "brand new essays" in order to provide insight into "the complete Harry Potter series (1997-2007) from a variety of critical angles and approaches" as the blurb on the back cover says.

Catching readers' attention just with their intriguing titles, each of the chapters provides new ways of reading the Harry Potter books on different levels. The issues of coming of age, race and gender, food, medicine, queer theory and occult elements, love and extratextual afterlife are eagerly discussed by the respective authors. The diversity of the topics and the diverse approaches to them within Harry Potter's world are primarily due to the broad range of expertise of the contributors, ranging from teachers, university 
professors, independent scholars and lecturers of literature, religion, film and medicinal humanities, even to a former Air Force flight surgeon.

The introductory chapter shows Hallett's strong disagreement with those critics who announce the death of the Harry Potter phenomenon, thereby providing the reader with an insight into the purpose of yet another book devoted to analysing the well-known magical series. Hallett claims that, instead of death, Harry Potter experienced a real boom after the last pages had been read and the last scenes seen, through various websites, theme parks, exhibitions, ebooks and audiobooks devoted to the life of the young wizard. Additionally, she states that "no one book can pretend to touch on all the themes, motifs, allusions or literary connections in the seven-book Potter series" (2) but this volume, metaphorically credited as "an incoming owl!" (7), tries to shed new light on some of the more obvious literary themes and some less apparent subjects found in the novels. Each of the paragraphs that follow is yet another incoming owl casting a glance into one chapter, or, better to say, one essay. However, in order to adequately understand the depth of the topics encompassed in the book, one must read the original writings brought to the readers by Hallett and Huey's own owl.

In the first chapter, Siân Harris takes the reader on a tour of the ways J.K. Rowling uses the food theme. "Glorious Food? The Literary and Culinary Heritage of the Harry Potter Series" draws connections between the process of reading food in Harry Potter and other canonical works it is repeatedly compared with. The midnight feasting in Harry Potter resembles the classic plot device used in the works of Enid Blyton, as does the traditional boarding school feasting menu, limited to a selection of widely recognized traditional British classic meals. This "lack of culinary diversity" (12) is in direct contrast to the multifaceted society and apparent commitment to multiculturalism evident in other aspects of the series. The extensive use of various sweets with amusing and vivid attributes invites direct comparison with Roald Dahl's Charlie and the Chocolate Factory (1964). This insight into the process of reading food offers the reader an additional view into other aspects of the books, such as oppressive gender roles associated with food and cooking, or social comments on kitchen slavery in the past. Beside this historical comment, reading food offers a layer of psychological meaning to food, such as modern day comfort eating or bonding over food, as well as other intratextual, intertextual and socio-political dynamics.

Many aspects of the books appear to fit into the fairy-tale framework observed from the individual portrayal of the characters, their point of view and their role in the plot, as well as some characteristics of the plot itself. This is the base for Anne Klaus argument in the second chapter "A Fairy-tale Crew? J.K. Rowling's Characters under Scrutiny”. After close examination of some fairy-tale characteristics of the plot, such as the "once upon a time" and "happily ever after" frame, she argues that this in fact is the only pure equivalence between the genres. Other apparent elements are belong to a multilayered and multifaceted modification of traditional fairy-tale elements, such as good and evil, the companion and enemy dichotomies, in which nothing is simply black or white, where the hero is dubious and is neither wholly heroic nor individualized, while the side characters are complex and not mere helper figures of the plot. According to Klaus, this "amalgamation of different literary traditions and frequent departures from the main plot" (32) is what differentiates this multilayered series from the traditional linear narrative structure of fairy tales. 
In the third chapter, Robert T. Tally Jr. takes into close consideration readers' possible lack of background knowledge, introduces the concept of the Bildungsroman and finally develops his argument to demonstrate that Harry Potter really belongs to this genre. He finds the series to be "a remarkable updating of the genre" (36) due to the maturation of the characters on various levels. Assuming that the audience is growing up with the characters, seven books could even be described as a navigational system along individual paths towards adult maturity. Even though it is a third person narrative, except for a few chapters, and despite the evident distance between the perspective of the narrator and that of Harry, the reader is able to follow the main hero's thoughts and experiences by constantly "looking over Harry's shoulder". Another crucial part of Potter's Bildung is his choice of collective over individual effort, with the help of characters that have mixed functions characteristic of the genre: educators, companions, lovers. The reader's ability to learn every magical and life lesson alongside Harry makes these novels didactical, education novels.

In her essay "Bewitching, Abject, Uncanny: Other Spaces in the Harry Potter Films", Fran Pheasant-Kelly draws parallels between the magical spaces of Harry Potter's world with real-life spaces. This is done particularly with respect to the resemblances between some events and historical movements in the series and real-time history. The Gothic setting of the magical world where there are almost no limits in comparison to the Muggle world is entered through a seemingly solid brick wall. Once there, there is a collapse of all the conventions known to young readers who allow themselves to be taken into a parallel universe as unreal as the reader permits them to be. These unreal spaces, as well as the internal spaces of the psyche, are more easily portrayed in the books where more is left for individual imaginary interpretation than in the films where the "utilization of acute camera angles and extreme perspectives" (50) is as important as it is necessary. This chapter draws special attention to the difference in the use of magic between child and adult viewers in respect of the events of 9/11 which may result in a different interoperation of the magical events portrayed in the films.

The next essay, by Charlotte M. Fouque, distinguishes between elements of free will and determinism which are in their core exclusive but somehow seem to be interdependent when it comes to Harry Potter. The first element to underpin this is the role of the Sorting Hat, which is "essentially an instrument of fate" (74) and therefore deterministic, but in fact allows Harry to act of his own free will and make the choice himself of the Hogwarts house he will join. This represents a great lesson in the series, where one's own destiny is defined by free choice, but this in fact is ambiguous because the events could be viewed as predetermined due to Harry's lineage. This is merely one of many examples that Fouque provides in the fifth chapter illustrating the differences and similarities between free will, determinism, choice making, destiny and prophesy in the Harry Potter series.

Chapter six, written by Lykke Guanio-Uluru, under the title "Dumbledore's Ethos of Love in Harry Potter" can be observed in close connection with Jim Daems' essay "II Knew a Girl Once, whose Hair...': Dumbledore and the Closet" in the twelfth chapter as they both present certain aspects of Dumbledore's love. On the one hand, Guanio-Uluru explores Dumbledore as "the center of ethical authority" (84), a source of many life lessons about the importance of love and the limitations caused by the inability to love, as well as his role as a substitute father figure to Harry and "an agent of Harry's moral growth" (76). On the other 
hand, the reader must overcome the inner battle of accepting or not accepting Dumbledore's new closeted homosexuality. Different stages of love and different interpretations of it, the power of love and the self-sacrifice it ultimately leads to are all profoundly explored in the sixth chapter. In contrast, all chapter twelve seems to offer is debates on sexuality and positive and negative responses to Rowling's outing of Dumbledore without any regard to the concept of love. This in fact is understandable given that there is no evidence to support J.K. Rowling's announcement at Carnegie Hall about Dumbledore being gay. As can be observed, these two chapters oppose each other in many different aspects. While GuanioUluru stresses the importance of the implied author, Daems discusses if Rowling herself had the right to claim that the character is something just because she says so, even though there is no proof of it within the corpus of text. In his opinion, "without textual support for Rowling's claim, positive readings are trapped within negative stereotypes" (163).

The total of Harry Potter books sold worldwide comes to 400 million copies, testifying to its popularity. However, the series has also received certain complaints and challenges, mostly directed towards sexual content, offensive language and violence. In addition, problems of the occult, the demonic and witchcraft have arisen in North America. In chapter seven, Em McAvan strongly supports the opinion that there is no room for such accusations as this is a purely fictional text, that "there is no real Harry Potter engaged in witchcraft, no children casting spells or engaging in necromancers" (101) and, if taken like this, it cannot be considered as something of the devil or as an encouragement of the occult.

Besides the already mentioned coming of age, maturation and love topics, the Harry Potter books address other themes such as justice, political activism and the nature of authority. Such problems are considered in the eighth chapter written by Marcus Schulzke. He claims that the Harry Potter books do not promote any political ideology but offer a "model for engaged, democratic citizenship" (120) as well as a subtle commentary on discrimination, elitism, injustice, incompetence and abuse of power in the wizarding world and its institutions which is easily applicable to the counterparts in real life. The paradoxes of resistance depicted through Hermione's attempts to free the house-elves who do not want to be free "provides an excellent statement of a recurrent problem of political activism" (119) and nonexistent desire for social change. According to Schulzke, the great political value lies in the readers' ability to 'relate the books' themes to their own experience in politics" (120), regardless of their ideology.

Harry Potter's magical racism consists of the pure-blood, half-blood and Mudblood triangle, with the addition of Muggle status. Alongside this division of the wizarding population, Rowling presents the issue of giftedness. In chapter nine, Tess Stockslager emphasizes "the racial aspect to draw analogy between half-blood identity and biracial identity" (123). Within a stricter definition of the term half-blood as someone with only one magical parent, she presents her case through the series where there are only three characters with a magical mother and a Muggle-born father - Seamus Finnegan who is frank about his descent, Severus Snape who is silent about it, and ultimately Voldemort who goes to great lengths to deny his blood status. The wizards' blood status is compared with its real-life counterpart of biraciality and the discrimination it is closely accompanied with. As a moral lesson drawn from the series, Stockslager presents one's ability to differentiate among what can and cannot be changed within oneself. 
In the chapter "Magic, Medicine, and Harry Potter", various insights into the similarities between traditional medicine topics and medical care in the wizarding world are offered, and Clyde Partin explores "the threads of medicine and medical care woven into the novels" (135). An astonishing number of injuries to Hogwarts' students and staff are treated in the Hospital Wing of St. Mungo's Hospital, bearing remarkable resemblance to the real word - from stereotypically female nurses and male healers to the hospital name that "invokes traditional Catholic benevolence" (141). Most of the injuries and their medical treatment are imaginative but still based on pharmacological reality, be they a matter of herbology, potions and antidotes, or simple solutions such as sweets and candies. Even the schooling system bears a resemblance to medical training.

Roslyn Weaver and Kimberly McMahon-Coleman express their views on family portrayals and different types of mothering figures in Harry Potter. In that sense, the series is based on a hero's quest, starting with the loss of his parents, therefore family, to making his own family. Along the way, he is exposed to various types of mothering that can be portrayed, with reference to C.S. Lewis, as categories of the Lioness, the Witch and the Wardrobe. The Lioness mother is "a protector and defender of children, even to the point of death" (151) and is represented primarily by Lily Potter, but can be observed in Barry Crouch's mother and Tonks as well. On the other hand, Petunia Dursley, Narcissa Malfoy, Eileen Prince (Snape's mother) and Voldemort's mother are the motherhood type of the Witch as they "reject and neglect children, failing entirely as mothers" (150). Thirdly, the Wardrobe mothers "care and provide for children, offering material - and moral - care" (ibid.); in the series, these are Professor McGonagall, Mrs. Longbottom, and, the most obvious example, Mrs. Weasley. Harry Potter also portrays two main female characters, Ginny and Hermione who "are explicitly positioned as the mothers of the future who embody the best of the Lioness and the Wardrobe" (157).

In the last chapter, "Neither Can Live while the Other Survives", Pamela Ingleton discusses the "Extratextual (After)life of J.K. Rowling" (175). Given the breadth of the discussion, various themes are subjected to analysis - the death of the author, extratextual existence through interactive online interfaces such as www.pottermore.com, authorial intentional fallacy, the legitimacy of authorship, and much more. From all the comments made, it is clearly observed that Ingleton disagrees with Rowling's attempts of "asserting and reasserting (authorial) control over her text(s)" (175) as well as her careful monitoring of her brand. She compares the author with her main villain, Lord Voldemort, in terms of their biggest fear - death, and in her case "the death of the author", with reference to Roland Barthes (177). Rowling continually emphasizes her role, her work, her version, her world, her characters, her creation, expressing her "evident control issues" (182). She tries to control her fans as well, believing she has the right to select those who are worthy to be her fans. Ingleton holds against Rowling the fact that she "has placed herself in a position of privilege over her readers" (184) manipulating therefore both the text and extratextual conventions to avoid the death of the author. In her opinion, in this life and death battle it is more likely that the text will outlive its author.

In the process of creating this book, the editors have been asked to "commission a sequence of original essays that will introduce the reader to innovative critical approaches" (vii) to Harry Potter. I would say that the success of this task depends primarily on the 
depth of readers' previous knowledge and thought given to the topic, as well as the Harry Potter studies previously read. Some topics covered in the essays will surely shed some new light on the series for some readers, while others will reinforce existing knowledge. Nevertheless, it can generally be said that reading this book will raise and inspire new thoughts, ideas, opinions, debates, and who knows what else. For those whose hunger for new Harry Potter knowledge is not satisfied by this book, a detailed list of further reading is provided at the end.

Maja Njire

\section{Odgojno-obrazovni potencijal slikovnice}

\section{Marnie Campagnaro. 2012. Narrare per immagini: uno strumento per l'indagine critica. Lecce: Pensa Multimedia, 244 str. ISBN 978-88-6760-060-1}

Talijanska istraživačica s padovanskoga sveučilišta Marnie Campagnaro svoj je doktorski rad preinačila u knjigu Narrare per immagini: uno strumento per l'indagine critica. Knjiga se bavi pedagoškim mogućnostima slikovnice, odnosno jednoga njezina sastavnog dijela - vizualnoga.

Ta tema zahtijeva interdisciplinaran pristup. Autorica je takav pristup i odabrala, a svoj je izbor obrazložila u prvome poglavlju. Iz njegova se naslova „Letteratura per l'infanzia e approccio interdisciplinare: le ragioni di una relazione“ iščitava polazišna disciplina - dječja književnost. Bilo bi pogrešno reći da je ta disciplina i primarna jer su ciljevi knjige više pedagoško-metodičke prirode. No, ima li se na umu činjenica da se dječja književnost na talijanskim sveučilištima još uvijek predaje ponajprije na odsjecima za obrazovne studije, takvo tumačenje ne bi bilo neočekivano.

Da je dječja književnost tek podloga jasno je i iz drugoga poglavlja, naslovljenoga „Elementi strutturali e caratteristiche morfologiche dell'albo illustrato“, u kojemu se donosi sažeti pregled osnovnih književnoteorijskih spoznaja o slikovnici. Te se spoznaje odnose na definiciju i prirodu slikovnice, njezine sastavne dijelove i komunikacijske kodove (ikonički, verbalni, grafički, tipografski, kod medijatora i načina čitanja te relacijski kod). Autorica je najavila zainteresiranost za vizualnu sastavnicu slikovnice posvećujući joj zadnje potpoglavlje drugoga poglavlja. U njemu je, s utilitarnim ciljem, pojednostavljeno podijelila slikovnice u dvije velike skupine. Prvu skupinu čine slikovnice s denotativnim, a drugu slikovnice s konotativnim ikoničkim jezikom. U slikovnicama s denotativnim ikoničkim jezikom slike su, ukratko, čvrsto povezane s tekstom, kraj je zatvoren, a interpretacija je priče jednoznačna. Slikovnice s konotativnim ikoničkim jezikom sadrže nove ikonografske kodove, kraj im je otvoren ili bez rješenja, a mogućnosti su interpretacije brojne.

U trećemu poglavlju, „Leggere gli albi illustrati: interesse epistemologico e contesti educativi“, autorica prikazuje suvremeno stanje u izdavaštvu slikovnica i potkrjepljuje ga statističkim podacima. U Italiji je slikovnica od 2007. do 2011. svake godine bila najobjavljivanija knjiga za djecu. Također, uočen je porast naklade slikovnica u tome razdoblju. Empirijskih istraživanja u vezi sa slikovnicom, međutim, nema pa istraživačica u tome području vidi mogućnost za vlastiti doprinos. 
Metodološka podloga autoričina istraživanja predstavljena je u četvrtome poglavlju naslovljenome „Elaborazione di uno strumento di analisi e valutazione dell'albo illustrato“. Istraživačka metoda koju je primijenila Marnie Campagnaro jest Delfi, kvalitativna metoda kojom se upitnicima ispituju stručnjaci. Talijanska je istraživačica prvo odredila kriterije za izbor stručnjaka (istraživača, ilustratora i urednika) i tragala za njima (što je bio vrlo složen i dugotrajan posao), potom je među priznatim i relevantnim stručnjacima odabrala određene vodeći se načelom da u svakoj podskupini bude pet domaćih i pet inozemnih stručnjaka.

U petome poglavlju autorica analizira prikupljene podatke i sintetizira istraživanje provedeno u suradnji sa stručnjacima te šestogodišnjim, osmogodišnjim i desetogodišnjim učenicima osnovne škole.

Odgojno-obrazovne potencijale slikovnice autorica je svrstala u četiri skupine: promicanje čitanja, vizualno opismenjavanje, razvijanje kritičke kompetencije i poticanje mašte. Istraživanjem je potvrđena pretpostavka da slikovnice potiču kognitivno-emocionalne procese povezane ne samo s razvojem mašte, već i s razvojem umjetničke osjetljivosti i kritičkoga mišljenja, stoga su poželjne i u starijoj dobi, a ne samo u jasličkoj i vrtićkoj.

Glavni zaključci knjige tiču se važnosti vizualnoga opismenjavanja učenika. U talijanskome obrazovnome sustavu, ističe istraživačica, ne posvećuje se dovoljno pažnje čitanju slika. Autorica je, stoga, predložila shemu vizualne gramatike slikovnice, odnosno sastavnice vizualne analize na četirima razinama: leksičkoj, morfološkoj, sintaktičkoj i semantičkoj.

Nedvojbena je vrijednost takve vizualne gramatike i za hrvatski odgojno-obrazovni sustav. Cijela knjiga ili neki njezini dijelovi mogu biti zanimljivi hrvatskim odgajateljima, učiteljima, metodičarima, teoretičarima dječje književnosti, stručnjacima vizualnih umjetnosti i mnogim drugim praktičarima i teoretičarima koji poznaju talijanski jezik. Stručnost i savjesnost u izradi knjige ne može se osporiti, što će čitatelji prepoznati već i listajući knjigu. Ona je, između ostaloga, bogato opremljena tablicama, grafikonima, ilustracijama, naslovnicama slikovnica, upitnicima i dnevnicima. Ipak, neki proučavatelji dječje književnosti nakon čitanja ove knjige možda neće biti zadovoljni. Mnoga bi se pitanja, naime, mogla teorijski raspraviti, ali se u knjizi ne razmatraju zbog primjene drugačije, dječjoj književnosti nesvojstvene, metodologije. Ipak, korisna je jer otvara mnoga pitanja za buduća istraživanja u različitim područjima.

Corinna Jerkin

\section{Dijete i zoo-svijet, ikonografska neotenija}

\section{Ana Batinić. 2013. U carstvu životinja: animalističko čitanje hrvatskih dječjih časopisa. Biblioteka Periodica Croatica. Zagreb: Hrvatska sveučilišna naklada i Filozofski fakultet, 341 str. ISBN 978-953-169-242-7}

Što se tiče suvremenoga pokreta za prava, odnosno oslobođenje životinja mogu se izdvojiti dvije ključne godine koje su inicirale zooetičke vizure; riječ je o 1970. godini kada britanski psiholog Richard D. Ryder uvodi neologizam specizam, a koji je oblikovao prema terminima rasizam i seksizam, te o 1975. godini kada Peter Singer objavljuje knjigu 
Oslobođenje životinja, koja je zadobila status 'biblije' pokreta za oslobođenje životinja. Poznato je da je Peter Singer pokret za prava, odnosno oslobođenje životinja proglasio posljednjim preostalim pokretom protiv diskriminacije Drugih, pokretom koji dolazi nakon abolicionističkoga, feminističkoga i drugih pokreta protiv diskriminacije. I dok su u anglosaksonskome području u opticaju tri termina za proučavanja kulturne povijesti životinja, odnosno o ulozi životinja u antropocentričnoj vizuri povijesti, tj. animalistički studiji, odnosno animalistika (animal studies), antrozoologija (anthrozoology) i antropologija životinja (anthropology of animals), u hrvatskom znanstvenom i kulturnom krugu uvriježila se je sintagma kulturna zoologija, odnosno kulturna animalistika, i to zahvaljujući Nikoli Viskoviću koji je 1996. godine objavio zooetičku knjigu Životinja i čovjek: prilog kulturnoj zoologiji te 1998. godine Kulturnu animalistiku (ur. Nenad Cambi i Nikola Visković), zbornik radova sa znanstvenoga skupa održanoga 1997. godine u Splitu. Tako te prve poslijeratne 1996. godine Nikola Visković, inače profesor prava na Pravnome fakultetu u Splitu, uvodi u našu svesrdno razjedinjenu zajednicu multidisciplinarni, interdisciplinarni i transdisciplinarni koncept kulturne zoologije, odnosno kulturne animalistike kao pandan anglosaksonskome konceptu animal studies.

Iznimno pomno osmišljena knjiga $U$ carstvu životinja: animalističko čitanje hrvatskih dječjih časopisa Ane Batinić pak u našu lokalnu sredinu 2013. godine uvodi koncept animalističkoga čitanja dječjih časopisa, slično kao što je to nedavno zbornik radova Književna životinja (ur. Suzana Marjanić i Antonija Zaradija Kiš, 2012.) dokumentirao, što se tiče hrvatskih prilika, stanje književne animalistike, dakle, proučavanje životinja kao književne činjenice. Sâma autorica na tragu književne teoretičarke Susan McHugh koja je detektirala kako književna animalistika počiva na svojevrsnom paradoksu: naime, životinja ima u obilju u književnosti kroz sva doba i kulture, ali rijetko su bile središnja točka sustavnih književnih studija - pokazuje da postoji zaista dobar teorijski i etički razlog da se u proučavanje životinja još intenzivnije uključi humanistika i time sugerira zajednički program „kreativnoga disciplinarnoga uznemirivanja“, kako je istaknula teatrologinja Una Chaudhuri. Naime, Ana Batinić sustavno je iščitala književne i neknjiževne priloge, i to iz animalističke vizure (animalističko čitanje), najznačajnijih domaćih časopisa za djecu i mlade. Riječ je o Bosiljku (1864. - 1868.) kao prvom domaćem časopisu za mlade; nadalje, o Smilju kao, kako autorica ističe, najdugovječnijem i najznačajnijem dječjem časopisu (1873. - 1945.) te o Smibu (Smilje i Bosilje), kao svojevrsnome nadomjestku i nasljedniku Smilja i Bosilja, a koji pod navedenim akronimom izlazi od 1970. godine. Inače, sâma je knjiga nastala na temelju sadržaja animalističkoga kolegija Snježane Husić na poslijediplomskom studiju na Filozofskome fakultetu Sveučilišta u Zagrebu.

U okviru navedenoga animalističkoga čitanja hrvatskih dječjih časopisa Ana Batinić zaključuje da je broj animalističkih priloga najmanji u Bosiljku da bi se njihov broj povećao u Smilju, i to osobito povećanjem broja ilustracija koje najčešće prikazuju životinje ili životinje i djecu. Riječ je o svojevrsnoj ikonografskoj dijadi u sklopu svima privlačne neotenije, tj. juvenilizma - mladenačkih karakteristika u odraslih jedinki, pri čemu životinje velikih, okruglastih očiju, jednako tako zaobljene glave, koje podsjećaju na dijete, imaju prednost, a što je sve danas izraženo u konzumerističkom simbolu Hello Kitty, označenu kao 'cute' (slatka). U Smibu, kako nadalje zamjećuje autorica, stilizirane životinje, realistično prikazane životinje ili njihove fotografije nalaze se gotovo na svakoj stranici. Odnosno 
autoričinim vrlo jakim zooetičkim zaključkom: “Čini se kao da se sve intenzivniji odmak od životinjskog u suvremenoj svakidašnjici nastoji kompenzirati sve većom uronjenošću u životinjski svijet na stranicama dječje periodike" (293). Navedeno se promišljanje uklapa u cinični paradoks našega odnosa prema životinjama, što, dakako, potvrđuje i prije spomenuta Viskovićeva knjiga koja ima kultni status među našim animalistima - i teorijskoga i aktivističkoga usmjerenja; dakle, danas kada je životinja, kao i cjelokupna priroda svedena samo na eksploatirajući objekt, u onome što animalisti nazivaju suvremenim holokaustom, začudo nije nestala i njezina simbolička vrijednost. Ukratko Viskovićevim određenjem - današnji odnos prema životinjama kreće se u okviru te cinične paradoksalne vrteške eksploatacije i simbolizacije.

Zamjetna je stoga izrazita zooetička vizura sâme autorice koja je daleko bliža kritičkoj animalistici Stevena Besta i Anthonyja Nocelle negoli animalistici glavne struje koja ne uključuje i zooetička promišljanja. Tako primjerice u poglavlju „Zaštita životinja, zoovrtovi i cirkuske životinje“ autorica spominje kako je kod nas već 1933. godine pokrenut prvi specijalizirani časopis za zootematiku. Riječ je o ilustriranome mjesečniku Zoološki vrtić (1933. - 1937.), časopisu koji je Ministarstvo prosvjete odobrilo kao lektiru učenicima, kao i za korištenje u svim školskim knjižnicama. Nadalje Ana Batinić, zamjećuje kako prve priloge o zaštiti životinja u suvremenome shvaćanju nalazimo tek u Smibu, no pritom ističe njihovu izrazito specističku obojenost, dakle, diskriminaciju na osnovi vrste gdje su biljne i životinjske vrste, u odnosu na ljudsku vrstu, determinirane kao uniženo Drugo. Naime, svi članci o zoološkim vrtovima objavljeni u Smibu smatraju odlazak u zoo-vrt pozitivnim iskustvom za djecu dok se nigdje ne iznose negativne strane zatočeništva životinja.

Jednako tako autorica pojedinim slučajevima dokumentira i specističku ideologiju. Navedimo neke primjere. Tako je primjerice Smilje djecu poticalo da uništavaju hrušteve kao navodne štetočine, ali pritom je uredništvo časopisa djecu upućivalo na tzv. (oksimoronsko) 'obzirno uništavanje, ubijanje': „U mnogih državah nagradjuju se ljudi za to, što ih utamanjuju. Treba dakle djeco, da i vi zatirete toga škodljivoga kukca, samo ne treba kod toga posla životinje mučiti, već ih podati krmkom, da je pojedu ili ih utopite u vrućoj vodi - u kropu“ (Smilje, 1. svibnja 1879). Nadalje autorica zamjećuje kako su u Smibu, sve do najnovijih godišta (2003., 2008.), specistički reprezentirane tzv. grabežljive životinje koje mogu ugroziti čovjeka kao i domaće životinje koje posjeduje. Pritom se u Smibovim rubrikama izbjegavaju eksplicitne teme o industrijskom uzgoju domaćih životinja budući da one, kao što to navodi Richard W. Bulliet, izazivaju u većini nas moralnu i etičku nelagodu te se o njima ne piše. Naime, neki misle (riječ je o vladajućoj dogmi koja nije daleko od kartezijanskoga promišljanja o životinjama kao res extensi) da su životinje samo strojevi za zadovoljenje ljudskih potreba pa je to još jedan razlog, zapaža autorica, da se o njima ne piše, odnosno kako navode zastupnici toga mišljenja, dogme - da ne zaslužuju da se o njima piše. Nadalje autorica zamjećuje kako se ekološka vizura u Bosiljku javlja u pričama kao i u esejističko-informativnim tekstovima, i to već prije 150 godina, što i ne čudi s obzirom da je potreba očuvanja prirodnih resursa dokumentirana već u našim srednjovjekovnim statutima, što je zamijetila Diana Stolac u članku „Ekološke teme u hrvatskim srednjovjekovnim statutima“, objavljenome u zborniku radova Ekologija u odgoju i obrazovanju (ur. Stipe Golac) iz 2004. godine. Danas se ekologija u Smibu promiče 
uglavnom u književnim prilozima ili pak u posebnim rubrikama poput Eko Eko Eko Blanke Radić, Ekosvijesti ili Najljepši školski vrt.

I time još jednom ističem: posebnu vrlinu knjige Ane Batinić vidim u njezinoj zooetičkoj niši. Tako npr. kada autorica spominje Davida Perkinsa i njegovu knjigu Romanticism and Animal Rights iz 2003. godine, u kojoj je spomenuti književni teoretičar iz poetskih svjetova engleskih romantičara iščitavao odnos prema životinjama, autorica ističe kako je Perkins uočio da su oni koji su prema zoo-svijetu osjećali suosjećanje često životinje uspoređivali s položajem robova i/ili slugu, i to posebice kada je riječ o domaćim ili radnim životinjama. Jednako tako Ana Batinić iščitava pojedine ideološke premise u recepciji kulturne animalistike. Npr. tako autorica dokumentira kako je novinarka Jutarnjega lista 2009. godine komentirala prvi kulturnoanimalistički kolegij, što se tiče dakako naše regije, pod nazivom Teološka promišljanja zoologije Željke Bišćan na Katoličkom bogoslovom fakultetu, te Ana Batinić zamjećuje kako je novinarka Jutarnjega lista pridonijela niveliranju animalističke tematike, aplicirajući kako za teologiju postoje daleko ozbiljniji problemi od teologije životinja. Inače godinu dana kasnije, točnije u ljetnom semestru 2010. Antonija Zaradija Kiš pokrenula je isto tako kolegij pod nazivom Kulturna animalistika na Hrvatskim studijima, tako da se nekako paralelno odvilo navedeno uvrštavanje animalističke matrice u studijske programe humanističkih znanosti.

I završno povodom navedene knjige Ane Batinić: ukratko, riječ je o prvoj knjizi na domaćem tržištu koja donosi animalističko čitanje hrvatskih dječjih časopisa, a pritom i razotkriva specističku ideologiju na njihovim stranicama, koju društvo konceptom nadzora i kazne upisuje u dječje svjetove, a koju djeca vrlo brzo usvajaju i kao etičku vertikalu. Nadalje riječ je o knjizi koja animalističko čitanje uokviruje zooetičkom nišom, čime je daleko bliža zooetici ovdje spomenute kritičke animalistike, kao i zooetici američke teoretičarke za prava životinja i feministice Joan Dunayer prema čijim teorijskim postavkama autorica zaključuje da su u Bosiljku i Smilju zamjetni starospecistički stavovi, a Smib svoja zapažanja o zoosvijetu nažalost uokviruje novospecističkim promišljanjima. Ukratko, riječ je o autorici čije znanstveno istraživanje počiva na tvrdnji Jeremyja Benthama: „,[n]ije pitanje u tome mogu li životinje misliti ili mogu li govoriti već mogu li patiti.“ Odnosno, kao što navode Alexandar Bar i Jan Söderqvist, autori Netokracije iz 2002., ne smijemo zaboraviti kako je najvažnija značajka totalističkoga mišljenja antropocentrički svjetonazor.

Suzana Marjanić

\section{Dvije knjige o regionalnoj književnosti}

Vanesa Begić. 2012. Suvremena književnost za djecu u Istri. Pula: vlastita naklada. 187 str. ISBN 978-953-573-110-8

Valentina Majdenić. 2013. Regionalni tekst dječje književnosti. Zagreb: Ljevak. 389 str. ISBN 978-953-303-580-2

U novije su vrijeme objavljene dvije knjige srodne tematike. Obje tematiziraju regionalnu književnost u rukama dječje čitateljske publike. Vanesa Begić piše o istarskoj 
dječjoj književnosti, a Valentina Majdenić o zastupljenosti djela slavonskih književnika u hrvatskim osnovnoškolskim udžbenicima u povijesnom pregledu.

Prilikom sistematiziranja ili uređivanja određene znanstvene građe nameće se potreba za povezivanjem s odgovarajućim kontekstom radi lakšega razumijevanja prilika unutar kojih je predmet istraživanja nastao, razvijao se te dosegao svoj vrhunac. U književnosti proces sistematiziranja započinje detaljnim iščitavanjem specifičnih elemenata teksta koji u tome procesu preuzima ulogu posrednika prema nekoj drugoj funkciji, tj. krajnjem motivu. Tekst kao posrednik služi i Valentini Majdenić prilikom istraživanja recepcije slavonske produkcije dječje književnosti u osnovnoškolskim udžbenicima, u knjizi Regionalni tekst dječje književnosti.

Metodološki okvir knjige čine dva vremenska razdoblja karakteristična, u povijesnom kontekstu, po specifičnim političkim i društvenim zbivanjima. Vremenski starije razdoblje predmet je istraživanja usmjerenoga na recepciju književnosti slavonskih autora u doba bivše Jugoslavije, tj. od 1970. do 1989. godine, dok istraživanje novijega razdoblja obuhvaća utvrđivanje prisutnosti slavonske književnosti u osnovnoškolskim udžbenicima u samostalnoj Republici Hrvatskoj, odnosno vremenski odsječak od 1990. do 2008. godine. Oba su razdoblja, prema autorici, utjecala na školstvo kao i na recepciju slavonskih autora u udžbenicima. Pojam regionalnosti i regionalne književnosti autorica definira kao uvažavanje razlika. U svoju analizu uključuje i književnike koji nisu 'izvorni' Slavonci, no pridonijeli su promoviranju slavonskoga zavičaja i kulture. Stoga Valentina Majdenić prilikom analiziranja udžbenika posebnu pozornost posvećuje zavičajnosti tj. dvama bitnim faktorima u slavonskoj književnosti - čovjeku i prirodi. Proučavajući slavonsku književnost u kontekstu povijesnih, društvenih i socijalnih mijena, autorica zaključuje kako su navedene prilike utjecale na specifičan karakter djela slavonskih književnika - ona su duboko povezana sa zavičajem i osobnom prirodom čovjeka (temperamentom), na koju se ne može djelovati, zbog čega su najčešće tragičnoga karaktera. Uvrstivši u svoju analizu dvadeset i pet autora, autorica ih dijeli na tri razine s obzirom na mjesto boravka, rođenja i književnoga djelovanja. Prvu razinu čine književnici koji su mjestom rođenja i svojim djelovanjem vezani uz Slavoniju. Slijede ih književnici koji su u Slavoniju došli iz drugih sredina i u njoj su književno djelatni. Posljednju razinu čine oni autori koji su u Slavoniji rođeni, ali su nastanjeni i djelatni i u drugim sredinama. Tematizirajući značenje i upotrebu udžbenika Valentina se Majdenić usmjerava prema autorima udžbenika kao posrednicima pri prijenosu informacija, tj. kao posrednicima između izabranoga teksta i recipijenta.

Istraživanje se sastoji od nekoliko, po autorici, ključnih elemenata koji su važni za shvaćanje recepcije nekoga književnika ili djela u određenom razdoblju. Prije svega autorica donosi kratku biografiju svakoga književnika, njegova najvažnija djela kao i njihove kratke sadržaje, a posebnu pažnju posvećuje analizi metodološkoga instrumentarija, tj. literarnoestetske komunikacije s didaktičkom funkcijom, u kojemu iščitava elemente zavičajnosti te analizira zadaće kojima autori udžbenika žele uspostaviti vezu između teksta i njegova recipijenta, npr. pitanja za interpretaciju ili pitanja povezana s jezičnim izražavanjem. Iako se u uvodnom dijelu tematiziraju povijesne prilike kao jedan od elemenata o kojima je ovisila recepcija književnika i njegova djela, kao i ideološke komponente koje su činile važan segment u uvrštavanju dječje književnosti u osnovnoškolske udžbenike, sama autorica kritički ne razmatra spomenute fenomene tako da čitatelj ostaje bez zaključka u 
pogledu veće ili manje recepcije određenoga autora u nekome od razdoblja. Jedini je kritički osvrt vidljiv u analizi djela Augusta Harambašića gdje autorica navodi kako je zbog svojega domoljublja Harambašić izostavljen iz osnovnoškolskih čitanki u vrijeme Jugoslavije. Specifičan je primjer recepcije književnika Grigora Viteza - jednoga od najznačajnijih predstavnika hrvatske dječje književnosti. Analiza otkriva kako je autor više zastupljen u osnovnoškolskim udžbenicima prvoga razdoblja, tj. u doba Jugoslavije, nego u razdoblju samostalne Republike Hrvatske. No, slučaj se Grigora Viteza dodatno ne objašnjava niti tematizira, nego se pozornost posvećuje metodološkom instrumentariju udžbenika.

Zanimljiv idejni koncept knjige narušen je nabrajanjem statističkih i faktografskih podataka pomoću kojih čitatelj stječe uvid u recepciju slavonske književnosti u različitim vremenskim razdobljima, no izostaju odgovori na pitanja koja se pritom javljaju, a povezana su s ideološkom komponentom i izvanknjiževnim strujanjima koja utječu na recepciju dječje književnosti u osnovnoškolskim udžbenicima u jednom i u drugom razdoblju.

Sličan je idejni koncept, povezan s recepcijom regionalne dječje književnosti, godinu dana ranije obradila i Vanesa Begić u knjizi Suvremena književnost za djecu u Istri. Poticaj za ovu temu bila je nedovoljna recepcija istarskih dječjih književnika u čitankama, ali i uopće u znanstvenim istraživanjima hrvatske dječje književnosti. Stoga autoričina analiza i nije usmjerena na recepciju zavičajnosti, nego na promoviranje i upoznavanje istarske književne produkcije.

U uvodnome dijelu autorica tematizira značenje i žanrovska određenja dječje književnosti nakon čega slijedi niz od dvadesetak istarskih autora koji su prema Vanesi Begić nepravedno zapostavljeni. Kao i u radu Valentine Majdenić, i u knjizi o istarskoj produkciji analiza se temelji na kratkoj biografiji književnika i kratkome sadržaju značajnijih djela bez zapaženije kritičke obrade. Najviše je pozornosti autorica posvetila književniku Danielu Načinoviću koji je ujedno i zastupljen izvan 'granica' istarskoga poluotoka. U analizu su uključeni i dječji časopisi, kao i književnici, koji nisu podrijetlom iz Istre, ali su njihova djela objavljena u Istri ili su mjestom radnje vezana uz Istru. U zaključnim razmatranjima autorica upućuje na specifičan karakter dječje književnosti istarskoga kruga koja je uglavnom dvojezična, tj. hrvatska i talijanska, a mahom se sastoji od pjesničkih ostvarenja.

Obje autorice u svojim istraživanjima kreću od vlastitoga zavičaja, no s različitim ciljem $\mathrm{i}$ ishodom teme kojom se bave. Valentina Majdenić istražuje recepciju slavonskih književnika u osnovnoškolskim udžbenicima i zastupljenost elementa zavičajnosti u metodološkom instrumentariju. Vanesa Begić svojim istraživanjem želi upozoriti na nepravedno zanemarivanje i ignoriranje istarske produkcije dječje književnosti. Svojim su zanimanjem za zavičajnu književnost autorice, svaka na svoj način, pridonijele književno-teorijskim istraživanjima dječje književnosti te proširile recepcijske granice književnosti za djecu.

Iako autorice imaju različiti pristup temi te se vode različitim motivima, odnosno svrhama istraživanja, njihova je analiza u nekoliko elemenata istovjetna. Ni jedna autorica ne posvećuje dostatnu pozornost kritičkoj obradi podataka pa tako izostaju odgovori na neka važna pitanja i pojašnjenja važnih fenomena koji su u istraživanjima uočeni, naročito zbog šire i kompleksnije razrade, u knjizi Valentine Majdenić. Većina je literature kojom se autorice koriste i koja se spominje u tekstovima zastarjela, tj. neke su teze do sada već opovrgnute (npr. navođenje romana Čudnovate zgode šegrta Hlapića Ivane Brlić-Mažuranić kao prvoga dječjega romana u hrvatskoj dječjoj književnosti, što polovicom prošloga 
stoljeća navodi Milan Crnković, a istu tezu u svojem djelu koristi i Valentina Majdenić iako je ona nekoliko puta opovrgnuta, npr. u istraživanjima Berislava Majhuta i Dubravke Zime). Šturi faktografski podaci, nabrajanja i suvišno opisivanje sadržaja analiziranih djela djeluju monotono i pridonose više statističkom, nego znanstvenom karakteru obiju knjiga. Ipak, obje su dobrodošle utoliko što uvode do sada nenačetu temu regionalnosti u područje istraživanja hrvatske dječje književnosti.

Martina Jurišić

\section{Obljetnica kao poticaj}

\section{Marina Protrka Štimec, Diana Zalar i Dubravka Zima, ur. 2013. Veliki vidar - stoljeće Grigora Viteza. Zagreb: Učiteljski fakultet Sveučilišta u Zagrebu, 485 str. ISBN 978-953-7210-62-5}

Znanstveni skup s međunarodnim sudjelovanjem Veliki vidar-stoljeće Grigora Viteza održan u Zagrebu 24 i 25. studenoga 2011. u čast stogodišnjice rođenja Grigora Viteza ove je godine rezultirao i vrlo opsežnom, metodološki zanimljivom i raznolikom monografijom. Knjiga sadrži trideset i tri članka čiji su autori, uz priznate domaće znanstvenike i poznavatelje dječje književnosti, i znanstvenici iz inozemstva. Kako i same urednice u uvodniku navode, tekstovi su, za razliku od referata održanih na skupu, uvelike izmijenjeni i dorađeni, što potvrđuje njihovu kvalitetu, te svojim rasporedom slijede strukturu samoga skupa. Zanimljivost jest mnogovrsnost perspektiva kojima se pristupa razumijevanju i tumačenju Vitezova djela.

U prvom dijelu Vitezov opus sagledava se iz književnopovijesne, teorijske, metodičke, ilustratorske i prevoditeljske vizure u namjeri da se revidira i novim pojedinostima osvježi suvremena pozicija Vitezova stvaralaštva, dok je drugi dio monografije okrenut trenutačnome stanju istraživanja unutar znanstvenoga područja dječje književnosti. Autori prezentiraju aktualnu problematiku koja zaokuplja suvremene istraživače dječje književnosti pritom koristeći nešto posebniji, odnosno suvremeniji metodološki aparat u analizi Vitezova pjesništva, usporedimo li ga s onim na koji nailazimo u prijašnjim kritičkim tekstovima o njegovu stvaralaštvu, ali i u analizi ostalih književnih djela i autorskih opusa. Tako Diana Zalar u članku „Koncentrični semantički krugovi književnoga djelovanja Grigora Viteza“ koristeći sintagmu koncentričnih krugova proširuje dosadašnja saznanja o Grigoru Vitezu koja su većinom obuhvaćala stilske i druge odlike njegove poezije za djecu, s dosad nepoznatom, bogatom rukopisnom bibliografijom u kojoj je Vitez još za života pokušao objediniti sva područja svojega književnoga djelovanja (književnik, antologičar, prevoditelj, jezikoslovac i sastavljač udžbenika, urednik, novinar itd.).

Rad Dragice Dragun prezentira zanimljiv pomak interesa s autora na ilustratora kao suautora imaginacijskoga svijeta Vitezove riječi. Autorica navodi imena ilustratora koji su dekodirali Vitezovu poetiku, počevši od prvijenca San borca u zoru do posljednje zbirke Kako živi Antuntun. Robert Bacalja u članku predstavlja Vitezovu poeziju u intertekstu hrvatske dječje poezije pritom izdvajajući motive koji su bili poticaj autorovu dječjem 
pjesništvu, ali i autorove motive koji su poticali suvremene hrvatske dječje pjesnike. Na primjerima iz Vitezova pjesničkoga opusa Domagoj Brozović predočava mehanizme gradnje nonsensne pjesme.

Marina Protrka Štimec, povezujući mimezu i igru, tumači Vitezov ludizam. Izdvajajući Vitezove pjesničke i prozne tekstove koji postaju plodonosni za razumijevanje određenih aspekata slobodne igre, autorica nudi nove mogućnosti tumačenja umjetničkih (književnih) i pedagoških praksi.

Tamara Grujić u radu istražuje koliko su Vitezov nonsens i igra zasnovani na tradiciji. Autorica nalazi kako Vitez, u namjeri da poduči i zabavi dijete, u svoje stihove ugrađuje žanrove usmene književnosti (narodne zagonetke i brzalice), pritom ih modernizirajući i prilagođavajući mladom čitatelju. Sličnom tematikom bavi se i članak Svetlane KalezićRadonjić u kojemu autorica upućuje na Vitezovo raznovrsno preoblikovanje i dograđivanje narodne pjesme inventivnim i neuobičajenim elementima.

O jedinoj Vitezovoj autobiografiji objavljenoj 1963. piše Vinko Brešić. Autor analizira pripovjedne postupke te ukazuje na društvene strategije koje utječu na oblikovanje autobiografskoga subjekta i na njegovu strukturu, povezuje ih s političkim i društvenim okolnostima nastanka teksta da bi istaknuo kako će se pojedine aporije na koje autobiografija upućuje moći riješiti tek objavljivanjem sustavnoga i kritičkoga izdanja Vitezova opusa.

Jasna Ažman prezentira pisma Ivana Brlića upućena Grigoru Vitezu od 1953. do 1960. godine kao prilog argumentaciji kako je Vitez svojim uredničkim posredovanjem visokoestetskih kulturnih i kritičkih normi uistinu nastojao redefinirati i preusmjeravati dotadašnju uređivačku praksu.

O kritičkoj recepciji Vitezova djela piše Ivan Bošković stavljajući naglasak na kritičke osvrte i tekstove koji su presudno utjecali na konstituiranje književnika Grigora Viteza u kanonsko ime hrvatske (dječje) književnosti. Književnom recepcijom pozabavila se i Dubravka Težak, no za razliku od Boškovića koji je usmjeren na akademsku kritiku i književnopovijesne preglede, autorica uzima u obzir i kritičku produkciju objavljenu u dnevnim novinama, dječjim publikacijama i pedagoškom tisku.

Vitezovim jezičnometodičkim prinosima bave se Bernardina Petrović i Jelena Vignjević. Rad analizira udžbenik Naš jezik: gramatika i pravopis za IV. razred osnovne škole koji je Vitez sastavio i objavio u suautorstvu s Ivanom Frolom 1947. godine. Autorice opisuju metodičke značajke udžbenika te analiziraju izvanjezične prilike u kojima je nastao. Istražuju kojima su se tadanjim suvremenim priručnicima poslužili autori te kako su se njihove teorijske i metodološke pretpostavke odrazile na metodiku hrvatskoga jezika.

Pedagoško-metodičkim aspektima Vitezova stvaralaštva zaokupljeno je nekoliko radova u monografiji. Članak Dijane Dvornik i Esmeralde Stanišić propituje ulogu naslova Vitezovih pjesama u pobuđivanju interesa učenika za čitanje, recepciju i pokretanje emocija. Teodora Vigato istražuje koliko su Vitezovi tekstovi prisutni na županijskim i državnim susretima LiDraNo te koliko su utjecali na stvaranje novih tekstova koji se izvode na toj manifestaciji. Scenskim potencijalom Vitezovih tekstova bavi se i Lidija Dujić, referirajući se na učestalost postavljanja igrokaza Plava boja snijega, koju evidentira i Teodora Vigato na LiDraNu, što se povezuje s praksom dijalogiziranja, uspavljivanja, razbrajanja prisutnom u mnogim Vitezovim antologijskim stihovima. 
O prvim prijevodima Vitezova djela na engleski jezik piše Smiljana Narančić Kovač, analizirajući prevoditeljske strategije i komentirajući pritom kontekste pojavljivanja pojedinih prijevoda. O slovenskim prijevodima Grigora Viteza i njegovoj recepciji u Sloveniji piše Milena Mileva Blažić, a pregledom recepcije Vitezova stvaralaštva u Srbiji pozabavio se Predrag Jašović. Sličnostima i razlikama Vitezove dječje poezije i poezije Jovana Jovanovića Zmaja bavi se Jovan Ljuštanović. Autor ispituje tematsko-motivske sličnosti i razlike dvaju pjesnika te impulse koji su stizali iz Zmajeva u Vitezovo djelo. Prvi dio monografije zaključen je člankom Tihomira Petrovića koji piše o stilskim, posebice zvučnim, osobitostima Vitezova poetskoga opusa.

Drugi dio, kao što smo istaknuli, usmjeren je propitivanju suvremenoga stanja dječje književnosti, a otvara ga zanimljiv i simptomatičan članak Berislava Majhuta koji se bavi „bijelim područjima i crnim rupama“ kao problemskim mjestima u povijesti hrvatske dječje književnosti. Autor ističe kako u povijesti hrvatske dječje književnosti postoje golema, posve neistražena „bijela područja“ koja tek čekaju da ih se omeđi i vrednuje, dajući prioritet rješavanju ,crnih rupa“, odnosno reinterpretiranju područja koja su obrađena $u$, danas neprihvatljivom, ideološkom ključu.

Marina Gabelica piše o budućnosti dječje knjige, odnosno o medijskoj rekontekstualizaciji pisanja, čitanja i objavljivanja dječje književnosti. Autorica navodi imanentne teorije iz područja digitalne poetike te primjere iz područja dječje književnosti koji su doživjeli takve pretvorbe, propitujući pritom odnose tradicionalnoga medija (dječje knjige) i novih oblika (elektronička dječja književnost), ali i njihovu recepciju u djece. Ivana Kukić Rukavina i Boris Kukić također donose primjer medijske rekontekstualizacije dječje književnosti u medij stripa. Berislav Majhut i Sanja Lovrić istražuju nakladničke strategije vidljive u distribuciji romana u svescima koji su se objavljivali početkom 1930-ih godina.

Dubravka Zima piše o liku adolescentice koji se pojavljuje u drugoj polovici devetnaestoga stoljeća. Autorica iščitava književne i paraknjiževne tekstove o adolescenticama i za adolescentice koji su bili dostupni do kraja devetnaestoga stoljeća, posebno se osvrćući na privatni adolescentski dnevnik Ivane Brlić-Mažuranić, pisan u razdoblju od 1888. do 1891. Marijana Hameršak istražuje strategije produkcije i recepcije bajki u Hrvatskoj u razdoblju između Prvog i Drugog svjetskog rata oslanjajući se na recentne dosege antropoloških studija djetinjstva koje shvaćaju djecu i mlade kao aktivne subjekte i društvene aktere. Ljiljana Pešikan-Ljuštanović u članku „Od zaštićenog do zaštitnika“ razmatra na koji se način fantastični dječji roman približava podvrsti fantastičnoga romana o spašavanju svijeta i ponovnom uspostavljanju narušene ravnoteže. Kao primjere uzima fantastične romane Zvonka Todorovskog Prozor zelenog bljeska i Mrlja te romane Aven $i$ jazopas u Zemlji Vauka i Peti leptir Uroša Petrovića. Tea Sesar na primjeru triju romana suvremene hrvatske spisateljice Nade Mihelčić pokušava pristupiti uobličavanju suvremene žanrovske romaneskne strukture unutar kanona dječje književnosti i književnosti za mlade. Kao dominantno načelo kojim se analizira uklopljenost unutar navedenoga kanona, autorica ističe analizu pripovjedne situacije.

Lana Mayer i Vedrana Živković Zebec u članku „Drukčiji anđeli“ bave se osobama s mentalnom retardacijom i invalidnošću koje imaju različite statuse u suvremenom društvu. Na primjerima iz hrvatske i njemačke književnosti autorice pokazuju kako se na mentalne 
poteškoće reagira s nesigurnošću, odbacivanjem i predrasudama, dok se pojedincima $\mathrm{s}$ tjelesnim poteškoćama pristupa sa sažalijevanjem i brižnošću.

U posljednjem članku zbornika Lilijana Burcar bavi se razotkrivanjem političkoga u dječjoj književnosti, odnosno društveno-ekonomskom eksploatacijom migranata i mehanizmima njezine neutralizacije. Autorica analizira roman Lawn Boy američkoga pisca Garyja Paulsena iz 2007. te prikazuje kako roman nesvjesno odobrava najnoviju logiku eksploatacijskih načina rada u obliku potplaćenih radnika imigranata koje roman čini gotovo nevidljivima, iako su nužni za glamurozni poslovni uspjeh glavnoga lika.

Monografija Veliki vidar - stoljeće Grigora Viteza predstavlja značajan doprinos proučavanju života i djela Grigora Viteza. Osvjetljavajući Vitezov opus iz različitih perspektiva, ova zbirka studija podastire nove, svježe poglede na autorovo stvaralaštvo, popunjavajući pritom mnoge praznine razmatranjem još neistraženih dijelova njegova života i stvaralaštva. S druge strane, monografija nudi vrlo važan i potreban sinkronijski uvid u suvremeni trenutak dječje književnosti, upućujući na veliki istraživački potencijal toga područja, čime ujedno dodatno osnažuje poziciju dječje književnosti kao teme istraživanja književne znanosti.

Katarina Ivon

\section{Znanstvena brižnost i marno sročene misli}

\section{Vinko Brešić, ur. 2013. Članci. Sabrana djela Ivane Brlić-Mažuranić. Kritičko} izdanje. sv. 4. Priredila Marina Protrka Štimec. Slavonski Brod: Ogranak Matice hrvatske Slavonski Brod. 290 str. ISBN 978-953-6842-29-2

U nizu „Sabrana djela Ivane Brlić-Mažuranić“ urednika Vinka Brešića objavljen je i četvrti svezak, u kojemu su sakupljeni svi članci koje je Ivana Brlić-Mažuranić za života objavila u periodici. Knjigu je skrupulozno i s velikom filološkom brižnošću priredila Marina Protrka Štimec, uvrstivši u nju publicističke članke, književne priloge, pripovijetke, pjesme, crtice i druge rubne književne vrste, poput, primjerice, prvotiska već višekratno spominjanoga i djelomice objavljenoga teksta nastaloga povodom smrti Ivana Mažuranića i zapisanoga, kako se to opetovano navodi, na koricama knjige koju je autoričin djed imao kod sebe u trenutku smrti.

Sabrana djela Ivane Brlić-Mažuranić u prethodne su tri knjige postavila vrlo visoke standarde kritičkoga izdanja književnoga teksta, posvećujući posebnu pažnju kolacioniranju različitih rukopisnih i tiskanih inačica pojedinih tekstova i utvrđujući na taj način konačne, kritičke verzije svakoga pojedinoga objavljenoga autoričinoga teksta. Četvrti svezak prema tekstu Ivane Brlić-Mažuranić postupa jednako pažljivo, donoseći za svaki objavljeni članak precizne bibliografske podatke i navodeći sve razlike među postojećim objavljenim i rukopisnim inačicama.

Kronološki je raspon objavljenih tekstova vrlo širok: radi se o razdoblju od 1903., kada u zagrebačkoj Prosvjeti autorica objavljuje prigodnu pjesmu „Jela i orao“, do 1938., godine autoričine smrti, u kojoj u zborniku posvećenom Camilli Lucerni izlazi njezina 
pjesma „Jesen“, također prigodna i također posvećena ocu kao i „Jela i orao“. Članci su u knjizi poredani kronološki, čime se vrlo precizno dobiva dojam o mnogolikosti interesa Ivane Brlić-Mažuranić, ali i o nekim trajnim sadržajnim ili emocionalnim preokupacijama koje iščitavamo iz pojedinih priloga.

Ivana Brlić-Mažuranić u književnosti se javlja, kao što je poznato, dječjim pjesmicama i pričama u dvjema knjigama (Valjani i nevaljani, 1902. i Škola i praznici, 1905.; obje su knjige objavljene u prvome svesku sabranih djela). Usporedo s time, međutim, kako se vidi iz četvrtoga sveska, u razdoblju od 1904. do 1907. spisateljica piše i objavljuje pripovijetke i crtice u kojima ne nalazimo izravnu referenciju na dječju književnost, te se potom, od 1907. do 1913. - u razdoblju u kojemu piše i objavljuje Šegrta Hlapića (i započinje Priče iz davnine) - ne javlja prilozima ni u novinama niti u časopisima. Godine 1914. objavljuje tri prigodna priloga: kratku osmrtnicu brodskome liječniku Marku Bobincu, tekst o dr. Dimitriji Demetru u kojemu je prigodničarski, glorificirajući diskurs nadopunjen privatnim reminiscencijama (apostrofiranjem rodbinske povezanosti s Demetrom i spominjanjem pisaćega stola iz Demetrove ostavštine koji se i danas čuva u spomeničkoj zbirci BrlićMažuranić-Ružić u Rijeci), te neobično intonirani feljtonski tekst „Popodnevni čaj“ napisan na njemačkom i objavljen kao feljton u Agramer Tagblattu. Sljedećih nekoliko godina, za vrijeme kojih piše i objavljuje „Priče iz davnine“ i rađa najmlađu kćer, ponovno se ne javlja prilozima u periodici, no zato tijekom dvadesetih i tridesetih godina objavljuje niz raznovrsnih priloga i tekstova, od kojih će neke objaviti i u knjigama (tri sveska objavljena 1934. i 1935. pod ujedinjenim naslovom Iz arhiva obitelji Brlić u Brodu na Savi). Među tim su prilozima najpoznatiji autobiografski i autopoetički tekstovi, kojima se u ovoj knjizi - prvi puta u cijelosti - pridružuje i autobiografski zapis o smrti autoričina djeda Ivana Mažuranića, koji je prethodno već djelomično bio objavljivan, ali bez zapisa o izvorniku ili podrijetlu teksta. Priređivačica napominje da je jedan dio teksta napisan na koricama knjige Camille Flammarion Terres $d u$ Ciel koju je na samrtnoj postelji čitao Mažuranić, na što upućuje i sama autorica u „Autobiografiji“ iz 1916., te zaključuje da je prvi, uvodni dio nadopisan naknadno. $U$ tom je nadopisanom prvom dijelu središnja iskazna instancija fokalizacija kroz svijest autorice kao petnaestogodišnjakinje i njezin naglašeno emocionalan rakurs u kojemu se intimno isprepleće s banalnim, a podražujuće sa svakodnevnim.

Mažuranićkini članci objavljeni u periodici za njezina života iznimno su zanimljivi za proučavanje i to na nekoliko razina, od kojih se kao prva nameće privatna, odnosno biografska. Osim „Autobiografije“, višestruko čitane i interpretirane, te nekoliko autopoetičkih tekstova, u taj bismo kontekst mogli uvrstiti i nekoliko članaka koje čitamo kao 'kriptirane' autofikcijske iskaze odnosno kao tekstove koji se - kriptirano ili ne - odnose na polje privatnosti. To su svakako tekstovi „Emaus“, „Pod božićnim drvetom“ “i „Mato“, te „Rečenica koja obuhvaća svijet". U posljednje vrijeme, kako se čini, upravo je autoričina privatnost dospjela u fokus javnoga proučavanja, s njezinom opsežnom privatnom korespondencijom kao ključnom referencijom, koja se koristi i kao književno-povijesni izvor (kao, primjerice, u slučaju Majhutova vremenskoga i književno-povijesnoga kontekstualiziranja nastanka romana Čudnovate zgode šegrta Hlapića u tekstu pridodanome drugome svesku Sabranih djela), ali i kao privatni i svojevrsni povijesni izvor (kao u slučaju Sanje Lovrenčić koja autoričinu biografiju romaneskno transponira u nagrađivanom romanu U potrazi za Ivanom 
ili kao u slučaju čitanja Jasne Ažman koja u tekstu „Život zapisan u pismima“, objavljenom 2013. u Hrvatskoj reviji, autoričina privatna pisma čita i u kontekstu biografije, ali i u kontekstu građanskoga života u Brodu za vrijeme autoričina života). U ovoj, četvrtoj knjizi Sabranih djela u spomenutim je tekstovima privatno pak kriptirano u književno i $\mathrm{u}$ tom se prijenosu privatno transponira u sentimentalnome, ali istodobno i ironijskome registru. Taj se ironijski registar najjasnije vidi u „Slikama u obitelji“ (objavljenima tek 1930. u Hrvatskoj reviji, ali nastalima - sudeći prema obiteljskim prilikama opisanima u njima - mnogo ranije), u kojima je prva slika, „Pod božićnim drvetom“, ugođajna, ponešto uzvišenoga tona tek mjestimice kontaminirana blagim ironijskim primjedbama, dok je druga, „Emaus“, neočekivano uspješno sljubila blagost i ironiju, dosljedno 'snižujući' registar i ironizirajući predodžbu toploga obiteljskoga ozračja. Obiteljski - uskrsni - izlet u vinograd, čiji se ironizirajući potencijal aktivira već u rukopisnome podnaslovu koji ne apostrofira Uskrs već 'provinciju' kao ključno mjesto čitanja, zapravo je priča o specifičnoj obiteljskoj dinamici u kojoj se usporednost dječjih i roditeljskih praksi razotkriva u svome ironičnome naličju: majčina 'sentimentalnost' i očeva 'praktičnost', roditeljski autoritet i dječje nerazumijevanje, odraslo i dječje kao razdvojeno i nespojivo, sjajno ilustrirano u mikroslici dječje svađe koju otac promptno rješava prijetnjom fizičkom kaznom, dok je dijete kojemu se prijeti uvjereno da će tata zaboraviti kaznu do prilike za njezinu realizaciju. Božićno je ozračje, međutim, drukčije, a pripovjedna strategija neobičnija jer se uzvišenost prigode, koja je s lakoćom anulirana prilikom uskrsnoga izleta, u ovome tekstu podcrtava roditeljskom fokalizacijom odnosno nastojanjem uživljavanja u dječju perspektivu koja se koleba između proklamirane i normativne blagdanske blagosti s jedne i iščekivanja, nestrpljivosti, žudnje za darovima i nepriličnoga mačkinoga ponašanja u svetoj noći $\mathrm{s}$ druge strane. Majčinsko je gledište pritom u jednome dijelu narativno povlašteno, te je slika majčinoga umora i zadovoljstva sjajna, upravo veličanstvena metafora obiteljskoga života i njegove nepredvidive dinamike koja je za majku i ispunjujuća i frustrirajuća, pri čemu nam se upotrijebljena metafora velike i male sunčanice i simbolika sunca čini naglašeno simboličnom za autoričin književni i privatni život. Majčinu sliku cvijeta sunčanice koja se okreće životodajnom suncu, ali od umora spušta glavu okružena malim, znatiželjnim i neumornim sunčanicama koje i na sunčevu zalasku uporno dižu glavicu, gotovo bismo mogli pročitati kao alegorezu o obitelji, majčinstvu, književnosti i depresiji, ekonomičnog, gotovo šturoga izraza. Međutim, uz dodatak očeve i kćerine podsmješljivosti koja slijedi majčinu priču, ta mikroforma dobiva na slikovitosti i literarnosti. Ujedno, obje su ove priče sjajna ilustracija autoričina autopoetičkoga jezičnoga iskaza objavljenoga u predgovoru Knjizi omladini, u kojemu jezik kojim stvara ocjenjuje nepogodnim za dulje forme, ali zato pogodnim za kraće poput bajke, crtice i feljtona. Lapidarna, gotovo feljtonska uporaba jezika u ove dvije priče, kontrapunktirana ironijskim, ali i simboličkim, pokazuje autoričinu dosljednu i promišljenu brigu o vlastitome izrazu, čak i u rubnim književnim ostvarajima.

$\mathrm{Na}$ spomenute se priče odlično nadovezuje prirodopisna crtica „Mato“, očito autobiografske provenijencije, izvorno objavljena u časopisu Priroda 1921., u kojoj autorica pripovjedno „dražesno“ izvještava o „malome svračiću koji ne zna kome da privoli“ (83), odnosno kojega autoričina obitelj prigrli nakon što djeca 'rastepu' njegovo roditeljsko gnijezdo, hrani ga i pripitomljuje, vodeći neprestanu bitku za njega s njegovim roditeljima 
koji ga nastoje ponovno privabiti k sebi. Obiteljsko ozračje i „dražesnost“, naglašeni u podnaslovu priče, u ovoj su priči suprotstavljeni veličajnosti prirode koju simboliziraju dvije odrasle svrake i njihova instinktivna, ali zastrašujuće uporna bitka za potomka. „Učini mi se ova ptica velikom, učini mi se njezin čin važnim i strašnim - učini mi se ovo tako čisti i neizmjerno velik čin prirode i osjetih, e se gotovo nikada još ne bijah našla ovako na samu licem u lice s prirodom“ (84-85), navodi autorica i ta njezina reakcija, koja se čini i instinktivnom, ali i svjesnom, ujedno i literariziranom, svjedoči o autoričinom osjetilnom biću kao primarno literarnom.

Nadalje, autobiografski i autopoetički tekstovi u ovome izboru - to su „Autobiografija“ i zapisi o postanku Šegrta Hlapića i Priča iz davnine, te „Rečenica koja obuhvaća svijet“, već su na mnogim mjestima tematizirani i čitani, no ovaj ih izbor ujedinjuje i time možda daje dodatnu dimenziju ukupnome znanju o autoričinom procesu pisanja: prigodnost i povod za svaki od ovih tekstova sugeriraju stanovitu nevoljkost da se vlastito ja i vlastito pismo javno artikulira, no sami tekstovi svjedoče drukčije. Naime, „Autobiografija“ nastaje na poziv JAZU, „Izjava autorice o postanku Priča iz davnine“ na poticaj iz ruske recepcije Priča, „O postanku Šegrta Hlapića“ na molbu češkoga nakladnika romana, „Rečenica koja obuhvaća svijet“" povodom proslave obljetnice Marije Jambrišak. U svakome je od ovih tekstova autorsko 'ja' samosvojno i sigurno, i svaki od njih to javno autorsko 'ja' oblikuje na sličan način, između praktičnosti neposrednih predložaka (postolarski šegrt, iskrice iz kamina, oluja) i uzvišenosti književne transpozicije. Supostavljanje 'zanatstva' naspram umjetnosti u poeziji, na što spisateljica s ponešto gorčine aludira u slavnome pismu sinu Ivanu povodom spekulacija o izvornosti Priča iz davnine, mogli bismo tako shvatiti i kao poetičku razliku između svakodnevnoga i književnoga, između običnoga i mističnoga, pri čemu su atributi mističnoga i uzvišenoga, povezani s književnim, naglašeno vidljivi upravo u ovoj knjizi koja dokumentira autoričinu prisutnost u javnome medijskome prostoru.

Posljednja je razina privatnoga, prisutna u ovome izboru, bavljenje obiteljskom ostavštinom Brlićevih: u Obzoru 1933. objavljuje Ivana Brlić-Mažuranić uvod izboru iz korespondencije Andrije Torkvata Brlića, odnosno bilješke o istaknutim članovima obitelji Brlić, naslovljene kao „pabirci“, koje potom, u godinama koje slijede, objavljuje u zasebnim publikacijama, za njezina života u tri sveska te poslije njezine smrti u još dva sveska. Autoričini „pabirci“ svjedoče o žaru kojim se primila posla sređivanja opsežne i kadšto nepregledne ostavštine obitelji svoga supruga, ali i o njezinome historiografskome instinktu. Ličnosti njezina svekra Andrije Torkvata Brlića (kojega nije upoznala) i njegovih muških predaka u njezinoj su obradi ujedno povijesne i privatne ličnosti. Središnju ulogu zadobiva svekar Andrija Torkvat, iz čijega dnevnika stječe jasnu sliku o njemu, koji je očito fascinira svojim uzbudljivim, aktivnim i neobičnim životom i za kojega razvija, kako se čini, osobito razumijevanje upravo u kontekstu privatnoga. Andrija Torkvat sve je u životu, zaključuje njegova snaha, radio prerano i premlad - što je teza od koje kreću i neke recentnije povijesne studije o Brliću poput one Vlaste Švoger iz 2012. Proučavateljicama i proučavateljima života i djelovanja Ivane Brlić-Mažuranić ovi su njezini prilozi, pak, dodatno svjedočanstvo o autoričinoj okrenutosti prošlosti kao trajnoj životnoj i literarnoj fascinaciji, što je u knjizi nadopunjeno i prilozima objavljivanima u brodskim novinama o prošlosti svakodnevnoga i obrtničkoga života u Brodu. 
Potom, u knjizi nalazimo i zaseban krug prigodnih, odnosno publicističkih priloga u kojima autorica iskazuje svoje svjetonazorske ili pak poetičke pretpostavke („Ljubav“, „Mir u duši“, „Vedro pisanje je danas bez sumnje pravo herojsko djelo“, „Majka i socijalna skrb“, „O domaćinskoj školi Sestara milosrdnica u Požegi“ uz dodatak već spomenutih prigodnih tekstova), od kojih su poneki već interpretirani i tumačeni, poput predavanja „Mir u duši“ što ga je održala 1929. povodom Međunarodnoga dana mira i iste godine objavila u Hrvatskoj reviji, ili eseja „Ljubav“, napisanoga povodom međunarodnoga kongresa PEN-a u Varšavi, prvi puta objavljenoga u posebnom broju poljskoga časopisa Pologne Littérarie 1930. i iste godine u zagrebačkom Jutarnjem listu. Ono što, međutim, u ovome izdanju uviđamo kao neku vrstu poveznice $u$ autoričinome publicističkome rukopisu jest uzvišenost tona i jasna društveno-osjetljiva ili čak društveno-odgovorna pozicioniranost autoričinih teza. Poznato je da predavanje „Mir u duši“ govori o osobnoj odgovornosti i osobnoj dužnosti kao zalogu javnoga društvenoga mira, no i u svim se drugim publicističkim tekstovima provlači misao o pojedincu i zajednici i složenoj sprezi međusobne odgovornosti koja ih povezuje. Ljubav je, tvrdi Ivana Brlić-Mažuranić, ona koja potiče napredak, umjetnički i društveni, i to, dakako, individualna ljubav i stremljenje pojedinca, što se transponira u društveni napredak zajednice. Majka je, jednako tako tvrdi autorica, odgovorna za društveni boljitak ako na sebe preuzima i privatnu, obiteljsku dužnost, ali i podruštvljenu, javnu dužnost prema siročadi i djeci bez odgovarajuće roditeljske skrbi. Ispreplitanje osobne dužnosti i društvene odgovornosti konotira se pritom pojmovima uzvišenoga i svečanoga, pri čemu se neizostavno javlja asocijacija na uzvišenost umjetničkoga stvaranja koje obilježava cijeli Mažuranićkin opus.

Zasebnu cjelinu tvore književni tekstovi, prozni i pjesnički, objavljivani tijekom autoričina života, pa i neposredno nakon smrti. U ovoj ih je knjizi objavljeno devet, kao i dva u dodatku, od kojih je jedan prilično prerađena i trostruko dulja inačica pripovijetke „Seljačka košuljica“ (izvorno izašla 1906. u časopisu Hrvatska), koja je objavljena 1923. u Knjizi omladini pod naslovom „Nostalgija“ i s podnaslovom ,psihološka studija“, a i neke su pjesme također poslije uknjižene.

Imajući u rukama ovu knjigu Sabranih djela, bilo bi teško ustvrditi da su književni interesi Ivane Brlić-Mažuranić uski ili ograničeni - naprotiv, njezin poznati, uknjiženi književni opus svjedoči o gotovo neograničenom mnoštvu ne samo književnih interesa, nego i sadržaja i poticaja koje potom književno transponira. U tome smislu književni prilozi sakupljeni u ovoj knjizi ne iznenađuju motivskom množinom i raznolikošću koliko (uglavnom) usmjerenošću na ne-dječju publiku. Književni ugled ona stječe u polju dječje književnosti, no članci koje objavljuje u časopisima prije Čudnovatih zgoda šegrta Hlapića redom konstruiraju ne-dječjega implicitnoga čitatelja, a tematika i književna obrada ponešto podsjećaju na književne tekstove što ih u djevojaštvu zapisuje u svome privatnome dnevniku (koji je od 2010. dostupan pod naslovom Dobro jutro, svijete! u redakturi Sanje Lovrenčić), osobito po antitetičkoj strukturi i formi crtice ili „notice“, kako naslovljava jedan od tih tekstova.

Zaključno, Ivanu Brlić-Mažuranić odlikuje specifičan odabir rakursa u obradi teme što je jednako primjenjivo na publicističke i književne priloge. U tom su smislu indikativni upravo oni prilozi s najmanje ili bez književnih ambicija, koje bez iznimke odlikuje visoki 
stil i pomnost u upotrebi jezika, bez obzira na korišteni jezični kod (u knjizi su, naime, objavljena i dva članka izvorno objavljena na njemačkom jeziku, donesena u njemačkom izvorniku i hrvatskom prijevodu Milke Car). Također, i bez obzira na povod pisanju: Ivana Brlić-Mažuranić jednako ozbiljno pristupa i kratkoj osmrtnici brodskoga glazbenika Josipa Stane od samo nekoliko redaka, oduljem prigodnom članku o Dimitriji Demetru, kao i književnim tekstovima koji se u ovom izboru redom otkrivaju kao pomno strukturirane parabole. Ovaj je četvrti svezak Sabranih djela važan prinos razumijevanju njezina opusa, gotovo poput uvoda u djelo Ivane Brlić-Mažuranić ili neke vrste sažetka njezinih književnih i životnih interesa. Ujedno, ovim je sveskom zaokružen autoričin objavljeni opus i time, uz budući najavljeni svezak autoričine bibliografije, gotovo priveden kraju i projekt njezinih Sabranih djela, jedan od najboljih primjera filološke i znanstvene brige za književni opus nekoga autora u hrvatskoj književnosti.

Dubravka Zima

\section{Kako iskazati neiskazivo}

Kornelija Kuvač-Levačić. 2013. Moć i nemoć fantastike. Split: Splitski krug. 190 str. ISBN: 978-953-163-387-1

Uvriježeno je mišljenje da je fantastika u teoriji zanemarena književna vrsta, ali svejedno će svako doba, u skladu s dominantnim svjetonazorom, okušati svoje spoznajne alate na njezinu primjeru: od romantičara do psihoanalitičara, od strukturalista do poststrukturalista. Fantastika je posebno zahvalan predmet proučavanja zato što okreće leđa izvanknjiževnoj stvarnosti i odbija biti njezinim pasivnim zrcalom. Okreće se od sadržaja (koji je moguće parafrazirati jezikom sociologije, psihologije, filozofije, politike) i upućuje teoretičarev pogled na ono što je specifično književno, na stvaralačku moć književnosti. Usto, želeći dočarati nepostojeće, nemoguće ili nevidljivo, fantastika istražuje krajnje domete književne oblikotvorne snage. Fantastika se zapravo uvijek bavi samom književnošću, njezinim izražajnim mogućnostima i njihovim ograničenjima. A upravo je to tema koju u knjizi Moć i nemoć fantastike potanko obrađuje Kornelija Kuvač-Levačić. Autorica je docentica na Odjelu za kroatistiku i slavistiku Sveučilišta u Zadru, a ova knjiga nastala je na temelju istraživanja provedenoga za doktorsku disertaciju „Mitski jezik u hrvatskoj fantastičnoj prozi““. Znanstvena pedantnost prvo je što upada u oči pri čitanju ove knjige i uvelike pridonosi njezinoj čitkosti i preglednosti. Autorica se, naime, pridržava svih pravila znanstvenoga rada. U uvodu nam sažeto izlaže temu, potom opisuje metodološke spoznaje na kojima je temeljila istraživanje, definira korpus kojim se bavi te nakon njegove detaljne analize donosi iscrpan zaključak dopunjen, dakako, popisom literature i kazalima.

Autoričin korpus je vrlo jasno određen. Čine ga tri glavne antologije hrvatske fantastične priče: Branimir Donat i Igor Zidić, Antologija hrvatske fantastične proze i slikarstva (1975.), Ivica Župan, Guja u njedrima - Panorama novije hrvatske fantastične proze (1980.) te Prodavaonica tajni - Izbor iz hrvatske fantastične proze urednice Jagne Pogačnik (2001.), dopunjene još ponekom kratkom pričom i (detaljnije) romanima Pavla Pavličića (Koraljna vrata, Čelični mjesec, Večernji akt) i Gorana Tribusona (Snijeg u Heidelbergu i Potonulo 
groblje). Izvan dometa ovoga rada ostaju visoka fantastika i znanstvena fantastika te se na njih ne odnose niti dosegnuti uvidi. Doista, istraživanje tih grana fantastike istom metodologijom jamačno bi dovelo do zanimljivih, premda drukčijih zaključaka, što je važno imati na umu kako bi se izbjegle neprimjerene generalizacije o fantastici 'općenito'.

Autorica polazi od proturječja u samome srcu fantastike. Sam termin, naime, dolazi od grčke riječi fantastikos, vezane uz tvorbu slika i moć predočavanja. Ali istodobno, fantastika nastoji predočiti ono nepostojeće i nemoguće. No, njezine pretenzije ne staju na tome. Fantastika s lakoćom dočarava preobilje fantastičnih stvorenja, krajolika, bogova i junaka, ali teži prikazati i ono nedokučivo i neopisivo, a to je mnogo teži zadatak i po njemu se fantastika približava mistici. Zoran Kravar je naziva ,predvorjem transcendencije“ jer stiže do samoga praga misterija, gdje je, međutim, izdaje snaga budući da je ograničena jezikom koji je stoga njezino najjače oružje i najveće ograničenje, njezina moć i nemoć.

Upravo je jezik u središtu interesa Kornelije Kuvač-Levačić koja u ovoj knjizi spoznaje široke palete svjetskih teoretičara mita, fantastike i jezika (Jurij Lotman i Boris Uspenski, Mihail Bahtin, Tzvetan Todorov, Rosemary Jackson, Renatte Lachmann, Giulio Lepschy i mnogih drugih koje citira) primjenjuje na hrvatske fantastičare, povezujući njihova izražajna sredstva s mističnim diskursom koji se naziva apofatičkim. Apofatička teologija je, naime, ona koja se suzdržava od opisa božanstva iz uvjerenja da njegova transcendentna bit nadilazi ograničenja ljudskih kategorija, te smatra da je pravi put via negativa, opisivanje onoga što bog nije, umjesto onoga što jest.

Veza između fantastičnoga i apofatičkoga diskursa očituje se, kao što Kornelija KuvačLevačić pokazuje na brojnim primjerima, u a-komunikativnosti i anti-komunikativnosti fantastike, odnosno u prešućivanju ili čak hotimičnom zavaravanju čitatelja. Hrvatski fantastičari služe se tako „svetim“ i „profanim“(37) jezicima da bi mistificirali svoje iskaze, primjerice, vokabularom medicine, religijskoga obreda, stranih i pogotovo mrtvih jezika, spretno koristeći njihovu nerazumljivost u ušima laika i neiniciranih.

Fantastika se, moglo bi se reći, ne stidi svoje nemoći, nego je različitim pripovjednim strategijama stavlja u prvi plan, dičeći se svojim paradoksima i oksimoronima, poistovjećujući subjekt i objekt koji se prelijevaju jedan u drugi katkad dosežući mistično jedinstvo, katkad dražeći čitatelja nemogućnošću konačne spoznaje, a katkad u osporavanju logosa prelazeći u sferu dijaboličnog i grotesknog.

Vezu fantastike i mita više nije potrebno dokazivati jer su teoretičari (Northorp Frye, Mircea Eliade, Vladimir Propp i mnogi drugi) s različitih pozicija pokazali da su fantastika i bajka suvremeni baštinici određenih elemenata mita i mitske svijesti u našem sekulariziranom društvu, koji se očituju na razini teme, strukture i jezika u kojima se mit nataložio kao 'potonulo kulturno dobro'. Kuvač-Levačić tim se odnosom bavi analizirajući magijsku moć jezika u fantastici s performativnom moći mitskoga jezika da ozbilji ono što iskazuje, analizirajući kako u djelima hrvatskih fantastičara žive prokletstva i molitve, katkad u ironičnome kontekstu njihove nemoći, a katkad u sablasnome obistinjenju.

Autorica u završnome poglavlju sažima sve rečeno i naglašava zaključke koje je uvjerljivo i iscrpno potkrijepila preglednim i sustavnim primjerima, jasno dočaravši paralele između mitskoga i fantastičnoga diskursa te njihove implikacije za razmatranje fantastičnih pripovjednih strategija. Autorica uspješno pokazuje da upravo s pomoću igre uskrate podataka i razotkrivanja fantastika, ne krijući vlastitu jezičnu nemoć, poziva čitatelja na 
‘čitanje između redaka', pritom reorganizirajući čitateljevo iskustvo, čime paradoksalno iskazuje pravu performativnu moć fantastičnog diskursa, istinsku 'magiju jezika'.

Knjiga Kornelije Kuvač-Levačić uistinu je dragocjen doprinos znanstvenome proučavanju fantastike zahvaljujući svojoj znanstvenoj egzaktnosti i preglednosti, ali i rijetkom spoju pedantne skrbi za detalje i odvažnosti sveobuhvatne vizije.

Petra Mrduljaš Doležal 


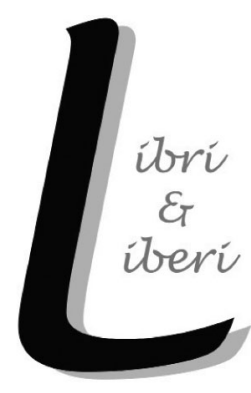

\section{Kronika Events}





\section{ChLA 2013 Conference Play and Risk in Children's and Young Adult Literature}

Biloxi, MS (USA), 13-16 June 2013

The $40^{\text {th }}$ annual conference of the Children's Literature Association (ChLA), hosted by the University of Southern Mississippi (USM), took place from 13 to 16 June 2013 at the IP Resort in Biloxi, Mississippi. Organized in collaboration with the ChLA, the USM Department of English, the USM de Grummond Children's Literature Collection at McCain Library and the USM University Libraries, the conference encompassed 14 concurrent sessions involving 80 panels with presentations from over 250 international scholars.

The central topic of this year's ChLA conference was play and risk, as these two notions have been interconnected with children's literature as both a literary and scholarly endeavour from its very beginnings. Ever present as a theme in many classic and contemporary works of children's and young adult (YA) literature, play and risk have proven to be very relevant concepts in the risky venture of constructing a scholarly discipline around a literary field once considered to be mere children's entertainment (or rather, 'children's play').

The papers presented covered a wide array of topics, ranging from semiotic studies of children's literature classics in terms of risk and play, and intriguing analyses of the rising global popularity of YA dystopian literature and its socio-political context, all the way to gripping debates on the common pitfalls in building an academic career in children's literature. This thoroughly engaging and thought-provoking exchange of ideas took place in the very appropriate setting (both playful and risky) of the IP's onsite casino.

The conference marked a very significant milestone for academic studies in Croatian children's literature, considering that the International Committee of one of the world's oldest and most renowned children's literature associations decided to choose Croatia as the special country-focus panel of its big $40^{\text {th }}$ anniversary celebration. Three Croatian scholars who had the honour to present recent academic research in the field of Croatian children's literature to a wide international audience were awarded international sponsorship grants. The panel Croatian Children's Literature was chaired by Professor Marek Oziewicz from the University of Wroclaw (currently employed at the University of Minnesota).

The paper "Croatian Children's Literature on the Verge of a New Period" by Berislav Majhut provided an overview of the history of Croatian children's literature and the theoretical efforts of its understanding. Instead of providing a list of authors and works, Majhut gave an overview of publishing activities and reading practices in Croatian children's literature. The paper presented recent developments in the field and the influences of the country's relatively recent transition from communism to democracy in the broader ex-Yugoslav context. At the same time, the paper stressed the importance of the traumatic experiences brought about by the Homeland War that are specific only to Croatia. The author concluded the presentation by highlighting the importance of interinstitutional networking, which can be achieved by making Croatian academic journals accessible to a wider international research community.

The paper "Glimpses into Contacts between Croatian and Anglo-American Children's Literature through Translations" by Smiljana Narančić Kovač gave a historical overview 
of the Anglo-American literature offered to Croatian children and YA audiences, while also presenting translations of Croatian children's literature into English from the mid-19 century onwards. After observing recent developments, the author found that contemporary Anglo-American literature is nowadays promptly translated and made readily available to Croatian children, while Croatian literature is still rarely translated into English. The paper explains the wider contexts and circumstances that influenced the developments depicted.

The paper "Love and Death in Croatian Children's Literature" by Željka Flegar discussed the legacy of the legendary Croatian author Ivan Kušan by observing his Koko crime series, which initiated the development of modern Croatian children's literature with the publication of the novel The Mystery of Green Hill (1956) and which was marked by a turn towards postmodernism in the metafictional novel Love or Death (1987). The author believes that, due to the fact that Love or Death brings together a very important part of Kušan's collected works, as well as various aspects of writing for children pertaining to the target audience, modernity and narrative structure, this work of fiction allows for an overview of trends, genres and crucial turning points in Croatian children's literature, and is a valuable contribution not only to its domestic culture, but to children's literature in general.

In addition to the above-mentioned scholars, two other members of the Croatian delegation had the opportunity to present papers on Croatian literature as part of the panel with a somewhat wider scope, notably Mapping Text and Translation in Slavic Children's Literature, chaired by Professor Marina Balina of the Illinois Wesleyan University.

The paper "It's a Kind of Magic: Ivana Brlić-Mažuranić's Croatian Tales of Long Ago - English Translations of a Central Piece of Slavic Children's Literature in Print and Multimedia" by Martina Jurić focused on a collection of stories that earned its author comparisons to H.C. Andersen and J.R.R. Tolkien and put a part of the Croatian national heritage on the shelves of many homes throughout the world. The paper analyzed and contrasted the two translations of Ivana Brlić-Mažuranić's stories (one by Fanny Susan Copeland, first published in 1924, and the other by Vlatko Broz from the 2002-2006 multimedia version) and their rendering of culture-specific items. It determined how the translators brought a part of the historical tradition of a small Slavic nation closer to the English-speaking reader in two very different historical contexts. Specifically, it identified the strategies employed by the translators and discussed their motives for choosing domestication or foreignization.

The paper "History Employed by the Present: The Case of the 1930s - Representation after 1945" by Sanja Lovric focused on the representation of the 1930s in Croatian children's literature in the period after 1945 as an example of how the extraliterary and historical context can affect the establishment of a canon and literary memory. The study focused mainly on the exploration of different actions and motifs aimed at 'adjusting' history to the needs of the post-war period. Given that at that point in time the cultural and literary memory of pre-war history was still very much alive, a newly constructed canon highlighted only a small part of the history and only a minor section of the literary works bearing importance for the dominant post-war perspective.

These two panels were preceded by a multimedia presentation on Croatian history and culture prepared by the members of the Croatian delegation that attracted a number 
of interested international scholars and provided the setting for the follow-up session. All of the papers received very favourable reviews and sparked debate. The Croatian team also managed to establish a book and information stand at the conference that attracted considerable interest from the participants. The materials provided by Croatian publishers of children's books and by authors of children's literature criticism were afterwards donated to the de Grummond Children's Literature collection. On the final day of the conference, a number of participants had the opportunity to visit the aforementioned library and enjoy a behind-the-scenes tour of the closed stacks and rare manuscripts.

The banquet held on the final day of the panels concluded the great celebration of 40 years of study of children's literature under the auspices of the ChLA. Of course, awards were also presented, with Gaye Hiçyilmaz, author of The Frozen Waterfall, winning the Phoenix Award, and Kevin Henkes being presented with the Phoenix Picture Book Award for his work Owen. The Phoenix Picture Book Honor Award winner Denise Fleming was recognized for her work In the Small, Small Pond. Jerry Griswold, Professor Emeritus at San Diego State University, delivered the Francelia Butler lecture and John Cech, Professor of English at the University of Florida, received the Anne Devereaux Jordan Award for Outstanding Achievement in Children's Literature.

The ChLA 2013 conference gathered a large number of internationally renowned children's literature scholars and provided a much needed platform for an exchange of new findings in the field and for the establishment of an international network of experts. Participation at the conference was both a great honour and challenge for the members of the Croatian delegation, and they once again proved that Croatia is an academic force to be reckoned with. The next ChLA conference Diverging Diversities: Plurality in Children's and Young Adult Literature Then and Now will be held from 19 to 21 June 2014 at the University of South Carolina, Columbia.

Martina Jurić

\section{Tomislav Torjanac u Galeriji Klovićevi dvori}

Zagreb, 19. studenoga 2013. - 12. siječnja 2014.

Među mnogobrojnim zagrebačkim izložbama mogli smo prisustvovati dugo očekivanoj, samostalnoj izložbi Tomislava Torjanca u Galeriji Klovićevih dvora, koja je trajala od 19. studenoga 2013. do 15. prosinca 2013. godine. Jedna je od svakako nezaobilaznih izložaba koja je, zbog zaslužno velikog interesa publike, produžena do 12 . siječnja 2014. godine. Takvim produženjem može se pohvaliti tek mali broj hrvatskih umjetnika. U izložbu uvode riječi uglednoga australskoga ilustratora i autora slikovnica i dječjih knjiga, Shauna Tana: „Svi dobri radovi govore sami za sebe, na svoj nenametljiv način, stoga je najbolji uvod jednostavno reći: dobrodošli u svijet Tomislava Torjanca, nadamo se da ćete uživati!“‘

Tomislav Torjanac jedan je od trenutačno najznačajnijih hrvatskih, ali i svjetskih ilustratora mlađe generacije. Po zvanju grafički dizajner, usmjerio se prema ilustraciji i slikarstvu, s istančanom sklonošću slikarskom izrazu, okarakteriziranom snažnim i vidljivo bogatim debljim i tanjim namazima kista, tako kreirajući kompleksno sazdanu formu. 
Ona ne umanjuje njegovu grafičku sklonost, itekako prisutnu u zanimljivoj kombinaciji tradicionalne slikarske tehnike uljanim bojama na drvenim pločama s grafički digitalno obrađenim fotografijama čija je računalna dorada gotovo nezamjetna i kao takva upravo ilustrativno namijenjena tiskovnoj formi.

U svom likovnom, slikarskom stvaralaštvu Torjanac se ističe realitetom prikaza bogatoga kolorita gradeći vrlo vješto i promišljeno slikarsku površinu, plohu i volumen koristeći izražajno sredstvo likovnoga elementa boje kontrastnim toplo-hladnim odnosima i tonskim svojstvima naznačujući opisno odnose ilustriranih prikaza. Također vješt u kompoziciji kadrova, ističe se neobičnošću i balansiranom dinamičnošću, živahnošću, razigranom maštovitošću, ali i bogatstvom detalja. Detalj je taj kojim Torjanac u svojim djelima, ovisno o karakteru namijenjene ilustracije, pretopljeno povezuje prošlost, sjećajući se mladosti svoga odrastanja, i današnjicu koja okružuje mlađe naraštaje. Pritom izražava i društvenu kritiku karikaturnim i humorističnim dosjetkama vrlo veselih i emocionalno nabijenih karakternih likova, razumljivu i odraslima i djeci.

Upravo tim raskošnim likovnim izričajem osebujnoga slikarskoga jezika, subjektivnoobjektivnoga pristupa i pobuđujućega istraživačkoga interesa, kao i dječačke zaigranosti s ilustrativno-pripovjedačkom širinom prenošenja cjelokupne priče, ilustracije odišu Torjančevom osobnošću neizgovorenih praznina koje pažljivom promatraču nude golemu mogućnost interpretacije.

Torjančeva izložba ilustracija postavljena je u prostorijama prizemlja Galerije Klovićevi dvori, u pet izložbenih dvorana s izloženih 108 radova velikih formata, predstavljajući cjelokupni opus umjetnika, uz pojedine kritičke i oduševljene komentare njegovoga rada te uz tiskovne primjerke ilustriranih knjiga iz mnogih zemalja.

Ulaskom u prvu izložbenu dvoranu susrećemo se s ilustracijama kojima se Torjanac na hrvatskoj likovnoj sceni pojavio za vrijeme održavanja Prvoga hrvatskoga bijenala 2006. godine, međunarodno nagrađenim romanom Yanna Martela Life of Pi [Pijev život]. Upravo tim ilustracijama postao je Torjanac svjetski prepoznatljiv i tražen autor, budući da je izdanje toga romana, s njegovim ilustracijama u boji, do danas objavljeno u prijevodu na četrdesetak jezika u različitim državama među kojima su mnoge s vrlo visokim zahtjevima u opremi knjiga, poput Ujedinjenoga Kraljevstva, Sjedinjenih Američkih Država, Južne Koreje i Njemačke. Britansko izdanje ilustriranoga Pijeva života nagrađeno je prvom nagradom na natjecanju British Book Design and Production Awards 2008 u kategoriji Limited Edition/ Fine Binding. Na temelju ove knjige snimljen je i istoimeni film redatelja Anga Leeja, u kojemu su pojedini filmski kadrovi nedvojbeno inspirirani Torjančevim ilustracijama.

Također su izloženi detaljni skicuozni crteži pojedinih ilustracija što, za razliku od izloženih konačnih ispisa velikoga formata, posreduju autentičnu bliskost gledatelja i ilustratora.

Drugi izložbeni prostor posvećen je ilustracijama dviju slikovnica. Prva je slikovnica Kako živi Antuntun, u kojoj je Torjanac ilustracijama dopunio i aktualizirao poznatu pjesmicu Grigora Viteza. Za tu je slikovnicu zasluženo dobio nagradu „Grigor Vitez“, potom nagradu „Lice knjige“ za ilustraciju i konačno književnu nagradu „Kiklop“. Druga je slikovnica Grga Čvarak, u kojoj je Torjanac prikladno oslikao istoimenu dječju pjesmu Ratka Zvrka, i koja je također dobila nagradu „Grigor Vitez“ za ilustraciju. U ovim se knjigama ponajbolje 
primjećuje Torjančeva dječačka zaigranost, ali i njegova sjećanja iz mladosti, obilježena kasnim sedamdesetim godinama prošloga stoljeća.

U istoj prostoriji veličinom i izražajnošću dominira i plijeni pozornost ulje na platnu veličine 200 x $130 \mathrm{~cm}$ što je ujedno i najveća slika u galeriji, za izložbu posuđena iz privatne zbirke, pod nazivom „Kad kroz žito ide, on sjeda u čun“. Upravo ta slika, iako izložena i u digitalnom obliku, pobuđuje interes i želju za viđenjem svih ostalih slika u izvornoj, slikanoj verziji.

Izložene su i ilustracije iz knjige Žabeceda, pomoću koje djeca uče abecedu, a autor ju je osmislio u suradnji sa svojom suprugom, Mihaelom Velinom.

U prolasku hodnikom iz drugog u treći izložbeni prostor izloženi su objavljeni tiskovni primjerci ilustriranih knjiga iz različitih dijelova svijeta koji promatrača, iako u nemogućnosti, pozivaju na listanje. Te su ilustracije ujedno i uvod u treći izložbeni prostor s ilustriranim ovitcima kratkih priča i knjiga poput djela Čarobnjak iz Oza L. Frank Bauma, Grijeh je umrijeti u proljeće Julijane Matanović, Iznenada netko pokuca Etgara Kereta, Beatrice $i$ Vergilije Yanna Martela, kao i mnogih drugih knjiga.

U četvrtom izložbenom prostoru kao zasebnom ambijentu odvojenu od ilustracija, serija je sanjivih slika pod nazivom „Somno“, izloženih uz ambijentalnu glazbenu podlogu koja blago odjekuje cjelokupnim galerijskim prostorom. Tu je glazbu skladao i izveo glazbenik Damir Urban. U prostoru se nalazi i krevet koji posjetitelja 'poziva' na odmor ne bi li usnuo i pridružio se Torjančevom maštovitom svijetu. Cijeli prostor je koncepcijski drugačiji od prethodnih što čini maleni odmak od dosadašnjih ilustracija, ispunjavajući izložbeni prostor relaksirajućom svježinom tajanstvenosti i sanjivosti.

Petim izložbenim prostorom nastavlja se slijed ilustracija iz knjiga. Tu su ilustracije u slikovnici Mačak $i$ vrag, nastaloj uz tekst jedine dječje priče Jamesa Joycea, koje su 2006. godine uvrštene i u najprestižniji američki ilustratorski godišnjak Spectrum. Slijedi slikovnica Djevojčica i div u suradnji s Neli Kodrič Filipić. Slikovnica je dobila nagradu „Lice knjige“ za ilustraciju i nagradu „Kiklop“. Konačno, tu su i ilustracije iz slikovnice Skakači koja sadrži priču Hansa Christiana Andersena.

Uz mnoge nagrade Torjanac se može pohvaliti i velikom nagradom (Grand Prix) na Četvrtom hrvatskom biennalu ilustracije održanom 2012. godine u Zagrebu, što ga dodatno, uz sva priznanja čini ilustratorom zasluženo vrijednim pozornosti zbog čega ova izložba ima itekako veliku kulturnu i likovnu važnost.

Vedran Markulin

\section{Ivan Kušan u Galeriji Učiteljskoga fakulteta}

Zagreb, 28. studenoga 2013. - 12. siječnja 2014.

Izložba ilustracija Ivana Kušana (1933. - 1912.) otvorena je u Galeriji Učiteljskoga fakulteta Sveučilišta u Zagrebu 28. studenoga 2013. godine, a traje do 12. siječnja 2014. Uz iskustvo čitanja književnih djela Ivana Kušana pridodajemo sada i iskustvo gledanja njegovih ilustracija. To komplementarno iskustvo dodiruje vizualna počela iz kojih izranja sadržina autorovih likovnih, a donekle i književnih interesa i doživljaja. No, prije nego što 
se uputimo u 'čitanje' likovnih djela ovoga autora, neophodno je ponoviti da je on prvo bio uronjen u studij slikarstva na Likovnoj akademiji u Zagrebu (diplomirao u klasi profesora Ive Režeka 1955.), potom uspješno zakoračuje u književnost, nižući svoja javna djelovanja u svojstvu sveučilišnoga profesora, prevoditelja i dramaturga, ponekad ilustrirajući, da bi naslov akademika okrunio njegovu časnu i vrijednu poziciju jednoga od korifeja hrvatske kulture.

Kako je Kušan formirao vlastitu poetiku ilustriranja, a cijeli taj opus nije bio poznat, bilo je potrebno na jednome mjestu skupiti sve ilustracije. Skupljene ilustracije izložene su u Galeriji Učiteljskoga fakulteta u Zagrebu te su tako široj kulturnoj javnosti omogućile uvid u koegzistenciju različitih izražajnih mogućnosti čije je izvorište jedinstveni autorov senzibilitet. Time se zapravo trebalo odužiti književniku i slikaru koji je i danas živa aktualnost hrvatske kulture.

Najbolji poznavatelj njegovoga rada na ilustraciji, Ivan Vitez, u predgovoru kataloga njegove samostalne izložbe notira sljedeće činjenice: „Vrlo rano je Kušan stekao afirmaciju nezaobilaznog pisca. Svoje knjige za djecu gotovo redovito sam ilustrira vrlo vještim i čistim pero-crtežom ili ilustracije kolažira rasterima, odnosno na crno-bijele ilustracije aplicira polutonove koji će u konačnoj izvedbi dočarati raspone od crnog do svijetlo sivoga, odnosno druge boje kao prateće za stvaranje tzv. lažnog kolora. Naime, bilo je to vrijeme kada je u našim uvjetima stvarna kolor ilustracija bila nedostupna zbog cijene, ali i grafičko-tehničkih nedostataka u izvedbi tiska. Stoga se svaki umjetnik nastojao različitim dosjetkama domoći tonskog bogatstva ako već nije bilo moguće izraziti se bojom. To je bio ujedno i istraživački ilustratorski rad u kojem su se posebno istaknuli Borivoj Dovniković Bordo, Mersad Berber, Vjekoslav Brešić, Nedjeljko Dragić, Aleksandar Marks, Zlatko Bourek i Pavao Štalter. To je ujedno i krug autora koji je snažno obilježio 70-te i 80-te godine u hrvatskoj ilustraciji. Ivan Kušan na početku stvaranja književnog romana za djecu pristupa topografskoj izradi bazične ilustracije u kojoj signira cjeloviti okoliš u kojem će se kretati kasnije napisani akteri pa točno određuje svaki pravac kretanja, portretira sve sudionike, razrađuje eksterijere i interijere poput urbanističkih planova i nacrta obitavališta, kako bi bio siguran da u zanosu pisanja ne učini pogrešku u smještaju nekih radnji ili opisu likova. Tako ilustracija Ivana Kušana postaje svojevrsni likovni libreto budućeg romana.“

Kušanove ilustracije slijede primjer tradicionalnoga impostiranja plošnoga prostora sa svom preglednošću i čistoćom koje dosiže njegov grafički izraz, ali nije mu strana ni inovativna komponenta tonski intoniranih sažetaka i vibrantnih tekstura. Rijedak je i po tome što prijevod iz književnoga u likovni govor ne zamućuje suvišnošću detalja, već dominanta kompozicijske preglednosti dovršava vizualnu pozornicu. Stvorivši tipološki odredljive fizionomije, pokrete koji se kreću urbanim krajolicima, često puta dirnuti atmosferom tajnovitosti možemo doživjeti uzbuđenja koja dodatno isijavaju iz teksta. Kao slikar, Kušan je brz u opservaciji minimalnim likovnim sredstvima (tuš - pero), dok su književni tekstovi više misaone složenice događaja, ambijenta i apostrofirane konkluzije unutar radnje. Ilustracije stoje na sredini puta između književnoga teksta i likovnoga izražavanja slikara. One su pomno građene grafičkim sredstvima, ali i prepune duhovitih iznenađenja. Sinteza su racija i emocije i upravo zbog toga one dograđuju sliku o umjetničkom senzibilitetu pisca i slikara koji je znao granice i mogućnosti ilustrativnoga uprizorenja književnoga događaja. 


\section{Manifestacija Hlapić 2013.}

Hrvatska, 2013.

Hrvatska udruga istraživača dječje književnosti organizirala je manifestaciju Hlapić 2013. u sklopu koje su stotu obljetnicu prvoga izdanja romana Čudnovate zgode šegrta Hlapića (1913.) Ivane Brlić-Mažuranić proslavile brojne institucije i pojedinci nizom znanstvenih, kulturnih, obrazovnih, sportskih, umjetničkih i drugih događanja. Različitim je aktivnostima u konačnici obuhvaćena široka

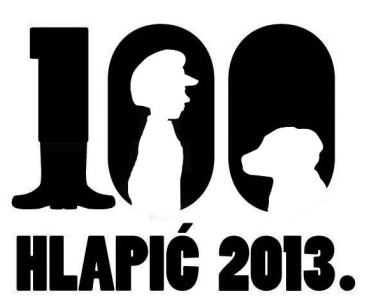
publika i pripadnici različitih dobnih skupina, a hrvatska se javnost podsjetila na ovo remek djelo hrvatske dječje književnosti, te se može reći da je cijelu godinu živjela s Hlapićem.

Središnji organizacijski odbor Manifestacije (Berislav Majhut, Smiljana Narančić Kovač i Ivana Faletar Horvatić) koordinirao je djelatnosti i ostvarivao kontakte s partnerima. U realizaciji programa naročito su se istaknule Corinna Jerkin, koja je brinula o aktivnostima u Rijeci, i Jasna Ažman u Slavonskom Brodu, a na nacionalnoj razini Kristijana Ferderbar, koja je brinula oko medijske promocije svih aktivnosti, Ljiljana Ivković, koja je koordinirala aktivnosti u projektu Stari obrti, Željka i Ivan Librić koji su koordinirali aktivnosti filatelista, Karolina De Vrgna, voditeljica projekta Online zgode Šegrta Hlapića, Marina Gabelica, koja je organizirala učenički natječaj Moj Hlapić za najbolje literarne, likovne i glazbene uratke, kao i Gordana Kešina, koordinatorica Hrvatske nastave u Švicarskoj. Za svaku zasebnu aktivnost odgovornost su preuzeli pojedinci iz ustanova koje su bile neposredni organizatori i lokalni provoditelji.

Za sudjelovanje u Manifestaciji službeno se prijavilo sveukupno više od 150 institucija, strukovnih udruženja i pojedinaca. Među njima, osim znanstvenih ustanova, najviše je bilo obrazovnih ustanova (dječji vrtići, osnovne i srednje škole, visokoškolske ustanove), dok je velik broj vrtića, njih čak 35, sudjelovalo u projektu Stari obrti. Iz područja kulture sudjelovalo je više od četrdeset ustanova - ponajviše knjižnice, kazališta, muzeji i galerije, centri za kulturu te Državni arhiv. Svoje aktivnosti prijavilo je i četrnaest udruga, po jedna izdavačka i produkcijska kuća, nekoliko pojedinaca, lokalnih i turističkih zajednica te jedna državna agencija i jedan sportski klub.

Prijavljeno je ukupno dvjesto i dvanaest aktivnosti. S logotipom Manifestacije održano je više od stotinu radionica, trideset izložbi, dvadeset i šest predstava, igrokaza i mjuzikala, petnaest kvizova znanja, različiti natječaji, a predstavljeno je i pet prigodnih poštanskih žigova. Organizirana su četiri humanitarna projekta i snimljena četiri filma, održane dvije međunarodne konferencije i jedan stručni skup. Stoga se ovdje ne mogu predstaviti sve održane priredbe, izložbe i aktivnosti, ali se njihov pregled može naći na Facebook stranicama Manifestacije (v. <http://tinyurl.com/mt9rwg5>).

Početak Manifestacije zapravo je upriličen već 13. prosinca 2012. godine u Villi Ružić, Spomeničkoj knjižnici i zbirci Mažuranić-Brlić-Ružić, otvorenjem izložbe umjetničke keramike Hlapić u božićnim jaslicama umjetnice Margarete Krstić. Svečanom postavljanju jaslica pod bor nazočile su Corinna Jerkin i Smiljana Narančić Kovač, koja je održala pozdravni govor u ime Hrvatske udruge istraživača dječje književnosti. U Villi Ružić je uskoro otvorena i izložba Ivanine riječke vedute te je krajem siječnja 2013., 
povodom manifestacije Noć muzeja 2013., predstavljen ruski prijevod Čudnovatih zgoda šegrta Hlapića. U Gradskoj knjižnici Rijeka započela je potraga za najstarijim izdanjem romana Čudnovate zgode šegrta Hlapića (v. <http://tinyurl.com/p $7 \mathrm{fct} 8 \mathrm{c}>$ ) te niz aktivnosti u organizaciji Učiteljskog fakulteta u Rijeci. Pod vodstvom prof. Maje Verdonik, voditeljice kolegija Dramsko i scensko stvaralaštvo i prof. Anite Rončević, voditeljice kolegija Metodika likovne kulture, studentice i studenti treće godine Učiteljskog studija organizirali su tijekom siječnja „Hlapićeve literarne i likovne majstorske radionice“ na Dječjem odjelu „Stribor“ Gradske knjižnice Rijeka. Studenti su za djecu izveli igrokaz - Bakmazovu dramatizaciju Čudnovatih zgoda šegrta Hlapića, a radionice su bile posvećene i Ivani Brlić-Mažuranić i likovima iz romana. Budući učitelji stekli su itekako vrijedno iskustvo interakcije s učenicima - koji su igrokaz pak ocijenili boljim i od knjige i od animiranoga filma. Vrijedni studenti i njihove mentorice također su tijekom 2013. godine održavali Facebook stranicu Hlapić za sva vremena (v. < http://tinyurl.com/nfffxkk>).

Početkom veljače u Manifestaciju se uključuje i Državni arhiv u Slavonskome Brodu, dok međunarodni karakter Manifestacija poprima uključivanjem organizacije Hrvatska nastava u Švicarskoj, djelatnici koje diljem Švicarske redovno provode brojne kreativne aktivnosti. Nekoliko osnovnih škola održalo je višednevne aktivnosti, poput kreativnoga čitanja lektire u OŠ Mladost u Zagrebu te oživljavanja starih zavičajnih obrta u OŠ „Tina Ujevića" u Krivodolu. Aktivnosti s naglaskom na zaštiti okoliša održane su u OŠ Prof. Filipa Lukasa u Kaštel Starom, dok su učenici u OŠ Đakovački Selci izradili vitraje koji sada krase unutrašnjost školske knjižnice.

Uspješnom Revijom na ledu Šegrt Hlapić proslavi se pridružio i Klizački klub Medo iz Zagreba, koji je izveo više od deset predstava tijekom veljače i prosinca 2013. godine u Zagrebu, Rijeci, Opatiji i Sarajevu. Uz Karlu Čurčić (Hlapić) i Tenu Čopor (Gita), kao i uz poznate hrvatske klizačice Sandu Dubravčić i Idoru Hegel te hrvatskoga profesionalnoga klizača Borisa Martineca, više od tisuću članova kluba i rekreativaca sudjelovalo je u reviji pod vodstvom Gorane Škalec Petrović.

Humanitarnu dimenziju Manifestacija poprima uključivanjem Strukovne udruge Portić, čije tete $i$ barbe pričalice svaku večer djeci s onkološkoga odjela bolnice Kantrida u Rijeci čitaju nove zgode šegrta Hlapića. Narodna knjižnica i čitaonica „Vlado Gotovac“ u Sisku organizirala je brojne aktivnosti za sve uzraste, od kojih je najviše pozornosti privuklo 1. nacionalno natjecanje u čitanju naglas, organizirano u partnerstvu s Komisijom za knjižnične usluge za djecu i mlade pri Hrvatskom knjižničarskom društvu. Finalno natjecanje organizirano je na međunarodnom sajmu knjiga i učila Interliber u Zagrebu uz sudjelovanje natjecatelja iz četrnaest županija (v. < http://www.nkc-sisak.hr/?page_id=9154>).

Rođendan Ivane Brlić-Mažuranić obilježili su zajedničkom akcijom Hrvatski savez za esperanto i Hrvatski centar za dječju knjigu, predstavljanjem romana na kineskom jeziku. Tim povodom u auli Gradske knjižnice u Zagrebu postavljena je prigodna izložba iz zbirke Hrvatskoga centra za dječju knjigu, koja je naknadno predstavljena i na sajmu Monte Librić u Gradskoj knjižnici u Puli, dok je na mrežnim stranicama Knjižnica grada Zagreba dostupno digitalizirano prvo izdanje romana na portalu Digitalizirana zagrebačka baština (v. <http://kgzdzb.arhivpro.hr/?sitetext=322>). U OŠ Ivane Brlić-Mažuranić Koška održani su Ivanini dani, ove godine posvećeni liku hrabroga Hlapića. Povodom Ivaninoga rođendana i Svjetskoga dana knjige i autorskih prava, OŠ Petra Zrinskog i Centar za kulturu 
i film „August Cesarec“ u Zagrebu organizirali su niz aktivnosti pod nazivom Noć knjige, tijekom koje su učenici i šira javnost mogli sudjelovati u kreativnim radionicama i kvizu, pogledati predstavu i nekoliko tematski različitih izložbi te poslušati pripovjedačicu Jasnu Held. Početkom travnja u OŠ „Stjepan Radić“ Božjakovina pokrenuta je akcija Hlapićev vremeplov. Učenici su samostalno istraživali, priredili scenarij, kostimografiju i scenografiju te pripremili i izveli predstavu Čudnovate zgode šegrta Hlapića, dok su se aktivnosti u nekoliko zagrebačkih narodnih knjižnica početkom travnja tek zahuktavale.

Svečana proslava u Hrvatskoj akademiji znanosti i umjetnosti, koja je održana 17. travnja 2013. godine, bila je službeno otvaranje Manifestacije i ujedno svečani početak Međunarodne znanstvene konferencije Od čudnovatog do čudesnog. Konferencija je bila središnja aktivnost cijele Manifestacije, a održana je u Zagrebu 17. travnja i u Slavonskom Brodu od 18. do 20. travnja 2013. pod visokim pokroviteljstvom predsjednika Republike Hrvatske Ive Josipovića. O proslavi i Konferenciji objavljen je opširan prikaz u prethodnome broju časopisa Libri \& Liberi, kao i o Međunarodnoj studentskoj konferenciji Veliki dječji književnicile kao univerzalni kapital, koja je održana u isto vrijeme, također u Slavonskome Brodu, u organizaciji Učiteljskoga fakulteta u Osijeku, tj. dislociranoga studija u Slavonskome Brodu.

Osim predstave iz redovnoga repertoara Kazališta Trešnja u Zagrebu, različite interpretacije dogodovština šegrta Hlapića prikazane su u kazalištima u Velikoj Gorici, Osijeku, Bjelovaru, Imotskom, Hvaru i u brojnim osnovnim školama. Vrlo zanimljiva bila je interpretacija izvornoga dramskoga teksta Ivane Brlić-Mažuranić, pod nazivom Šest konaka. Dramska skupina Društva studenata kroatologije Cassius, s Hrvatskih studija Sveučilišta u Zagrebu, u izvorni je tekst unijela postmodernističke intervencije dok je priča zaživjela u svibnju 2013. godine na daskama Kazališta Trešnja. Tijekom ljeta premijerno je izvedena predstava Čudnovate zgode Šegrta Hlapića u organizaciji Glazbeno scenskoga udruženja Stella Maris u Hvaru. Predstavu je u nekoliko ponovljenih izvedbi pogledalo više stotina domaćih i stranih gostiju tako da je postala najveći kazališni hit ovoga ljeta na Hvaru.

Svibanj je vrvio filatelističkim aktivnostima poput radionica u OŠ „Grigor Vitez“ iz Svetog Ivana Žabno i narodnim knjižnicama diljem Hrvatske, te proglašenja pobjednika Natječaja za naj pismo koji već drugu godinu za redom raspisuje Gradska knjižnica Velika Gorica, u suradnji s Hrvatskom poštom, povodom Svjetskoga dana pisanja pisama koji se širom svijeta obilježava 11. svibnja. Kontinuirani napori nekoliko udruga i pojedinaca rezultirali su prigodnom poštanskom markom u čast stote obljetnice Šegrta Hlapića, koju je od 4. rujna 2013. godine moguće kupiti u svim poštanskim uredima u Hrvatskoj. Pasionirani filatelisti i znatiželjnici su tijekom 2013. godine prigodne žigove mogli dobiti u Zagrebu u tri navrata: 18. travnja prigodom rođendana Ivane Brlić-Mažuranić, 4. rujna povodom izdavanja prigodne poštanske marke i 12. listopada povodom Hlapićeva rođendana. Osim toga žigovi su se mogli dobiti i u Poštanskom uredu Sveti Ivan Žabno 24. svibnja te 12. listopada u Poštanskom uredu u Križevcima. Jedna od značajnijih aktivnosti Manifestacije bilo je i snimanje milenijske fotografije na jezeru Bundek u Zagrebu, gdje je iskusno oko Šime Strikomana snimilo lik šegrta Hlapića i majstora Mrkonje koje su stvorili sudionici projekta Stari obrti. Nakon snimanja, veseloj djeci iz vrtića i škola pridružio se i zagrebački gradonačelnik Milan Bandić koji im je pomogao posaditi Drvo prijateljstva u čast prikazanim likovima. 
Likovna, odnosno umjetnička recepcija romana prikazana je putem brojnih izložbi. Tako je na Učiteljskom fakultetu u Zagrebu postavljena izložba Moj Hlapić, koja je tijekom ožujka okupila brojne umjetnike oko ideje da korištenjem bilo koje tehnike prikažu svoje viđenje Hlapićeva lika. Publika je na taj način upoznala i Očka Čitaćirka, koji je cijelu 2013. godinu posjećivao brojne hrvatske škole i u sklopu edukativno-lutkarsko-scenskih nastupa prenosio važne spoznaje o romanu. Nacionalna i sveučilišna knjižnica u Zagrebu u manifestaciju Hlapić 2013. uključila se izložbom Hlapićevih 100 u 100 koju su postavile Dunja Marija Gabriel i Amelija Žulj, a na kojoj je izdvojen i izložen fond relevantne građe iz Grafičke zbirke, Zbirke starih i rijetkih knjiga, Muzičke zbirke i Kartografske zbirke. Izložba je obuhvatila i priloge o Ivani Brlić-Mažuranić i Šegrtu Hlapiću iz različitih časopisa (Smilje, Hrvatska revija, Vijesti muzealaca i konzervatora Hrvatske, Znanje i radost) i knjiga (zbornici, disertacije, preradbe), te je predstavljen i reprezentativni katalog. Značajna je i izložba koju je organizirao Tiflološki muzej u Zagrebu, u suradnji s Hrvatskom knjižnicom za slijepe i Centrom za odgoj i obrazovanje „Vinko Bek“, tijekom 18. muzejsko-edukativne akcije Muzejske pričalice. Posjetitelji Tiflološkog muzeja u „Tamnoj sobi“ imali su priliku u mraku čuti priču o šegrtu Hlapiću i opipati nekoliko taktilnih skulptura, dok je u izložbenom prostoru postavljena izložba likovnih radova u izradi učenika Centra za odgoj i obrazovanje ,Vinko Bek“.

Svečana premijera igranoga filma za djecu Šegrt Hlapić redatelja Silvija Petranovića održana je početkom studenoga 2013. godine. Kako je uzastopno rušio rekorde gledanosti, film je proglašen najznačajnijim dječjim filmom 2013. godine. U suradnji Gradske knjižnice Zadar i Hrvatske knjižnice i čitaonice Sali sredinom prosinca predstavljen je kratki nijemi igrani film, snimljen u crno-bijeloj tehnici, u kojemu su glavne uloge tumačila djeca iz istoimenoga mjesta na Dugome Otoku. Film je moguće pogledati na Facebook stranici manifestacije Hlapić 2013., a prikazuje igranu verziju romana kakvu je bilo moguće snimiti i neposredno po objavljivanju romana (v. <http://tinyurl.com/123lg94>).

Tijekom Manifestacije, povećani broj aktivnosti odvijao se $u$ travnju, kada pada rođendan Ivane Brlić-Mažuranić, u lipnju, mjesecu kada je objavljen Šegrt Hlapić, te u listopadu. Ivana Brlić-Mažuranić dovršila je pisanje romana 13. listopada 1912., pa je to svojevrsni rođendan Šegrta Hlapića. Svečana proslava 101. Hlapićevog rođendana održana je nešto ranije, 3. listopada, u Kazalištu Trešnja, gdje je nekoliko organizatora predstavilo svoje aktivnosti prisutnim gostima. Prvo je predstavljeno video-izlaganje Karoline De Vrgna koja je opisala vrlo uspješan projekt Online zgode šegrta Hlapića, tijekom kojega je po prvi puta u nekoliko škola (OŠ Popovac, OŠ Bilje, IV. OŠ Bjelovar) lektira istovremeno obrađena uz pomoć Web alata 2.0 za daljinsko učenje u nastavi. Aktivnosti Narodne knjižnice i čitaonice „Petar Preradović“ Bjelovar predstavile su Snježana Berak i Vjeruška Štivić. Osim niza kreativnih, edukativnih i umjetničkih radionica, pričaonica i kreativne obrade lektire, korisnici knjižnice mogli su sudjelovati u natječaju Umjetnik - to sam ja! i u izboru za najboljega lokalnoga Hlapića, dok su polaznici tečaja znakovnoga jezika sudjelovali u programu obilježavanja ulaska Republike Hrvatske u Europsku uniju, predstavivši našu zemlju izvedbom pjesme „Šegrt Hlapićc na znakovnom jeziku. Gordana Škalec Petrović predstavila je ranije opisane aktivnosti Klizačkoga kluba Medo, dok je Verena Tibljaš predstavila aktivnosti Gradske knjižnice Rijeka. U sklopu vrlo zanimljive prezentacije, opisana je potraga za najstarijim izdanjem romana i predstavljena izložba svih pronađenih izdanja, a među njima i tek drugi 
poznati primjerak prvoga izdanja iz 1913. godine, kao i niz radionica i pričaonica koje su se tijekom godine održale na svim odjelima knjižnice.

Povijesni presjek manifestacije U svijetu bajki Ivane Brlić-Mažuranić, koja se tradicionalno održava u Slavonskom Brodu i koja je 2013. godine bila u znaku šegrta Hlapića, predstavila je Jasna Ažman nakon čega je Franciska Jurišić Bačić opisala aktivnosti koje su se odvijale u Narodnoj knjižnici Blato, s naglaskom na plesnoj predstavi koja je izvedena u suradnji s plesnom skupinom Mila i OŠ Blato. Aktivnosti Dječjeg vrtića „Zvončić“ iz Našica predstavile su odgojiteljice Nada Delić-Crnković i Snježana Brezovec, koje su tijekom Manifestacije mlađahne polaznike vrtića upoznale s brojnim starim zanatima i uvele ih u kreativnu nastavu odnosno radionice. Proizvode nastale na radionicama učenici su potom prodavali na završnoj svečanosti, nakon čega su roditeljima predstavili i glazbeno-dramsku interpretaciju romana.

Spomenka Štimec upoznala je prisutne s radom Hrvatskoga saveza za esperanto te aktivnostima koje su se tijekom 2013. godine provodile s Hlapićevim predznakom, kao i $\mathrm{s}$ velebnim prijemom romana $\mathrm{u}$ azijskim kulturama nakon prijevoda na esperanto. Vesna Radošević iz Knjižnice Novi Zagreb (KGZ) opisala je projekt 365 konaka šegrta Hlapića u Knjižnici Novi Zagreb tj. brojna gostovanja i radionice stranih i domaćih gostiju i ilustratora. Razvoj i djelovanje Hrvatskoga školskoga muzeja predstavila je Štefka Batinić, koja je ujedno najavila i otvorenje velike izložbe 14. studenoga 2013. pod nazivom Kao Hlapić i Gita: siročad u Hrvatskoj na prijelazu iz 19. u 20. stoljeće.

Nakon predstavljanja aktivnosti na proslavi je Hlapićeva rođendana svečano promovirano i prvo izdanje romana za dječje čitatelje načinjeno prema originalnom rukopisu Ivane Brlić-Mažuranić, bez uredničkih ispravaka i s njenim omiljenim ilustracijama češkoga umjetnika Josefa Lade, a u izdanju nakladničke kuće „Nova stvarnost“. Tekst je toga izdanja prema izvorniku priredila Jelena Vignjević, a knjigu je uredio Zvonimir Maštrović. Tijekom neslužbenoga dijela programa podijeljene su zahvalnice svim institucijama i pojedincima koji su prijavili i vodili aktivnosti tijekom Manifestacije, dok je Mile Biljanović, glavni glumac igranoga filma Šegrt Hlapić, uz pomoć prisutnih gostiju ugasio svjećice na rođendanskoj torti. Svečanoj proslavi Hlapićeva rođendana odazvali su se brojni organizatori aktivnosti iz svih krajeva Hrvatske, koji su u predvorju Kazališta Trešnja mogli razgledati izložbu radova pristiglih na natječaj za dječje literarne, likovne i glazbene uratke Moj Hlapić, objavljen u dječjem časopisu Prvi izbor. Nagrađeni dječji radovi objavljeni su u publikaciji dostupnoj na mrežnim stranicama udruge HIDK (v. <http://tinyurl.com/k3lnob6>).

HIDK je također, uz potporu Ministarstva kulture RH, pokrenula i mrežni projekt Hlapić - promicatelj hrvatske kulture, koji predstavlja roman međunarodnoj javnosti kroz prijevode na druge jezike (v. $<$ http://hlapic.org $>$ ).

Sama Manifestacija bila je, zaslugom svojih partnera, dio drugih nacionalnih manifestacija, kulturnih događanja i kampanja, kao što su: Noć knjige, Noć muzeja, Mjesec hrvatske knjige, Dan pismenosti, U svijetu bajki Ivane Brlić-Mažuranić, Festival dječje knjige i kampanja Čitaj mi! O manifestacijama i pojedinačnim aktivnostima objavljivani su članci u časopisima Prvi izbor, Hrčak - glasilo Hrvatskog čitateljskog društva, Novosti Hrvatskog knjižničarskog društva i Libri \& Liberi, kao i u dnevnom tisku te na mrežnim stranicama novinskih portala. Članovi organizacijskoga odbora nekoliko puta su gostovali 
u programima nacionalne televizije (Dnevnik, Dobro jutro, Hrvatska, Pola ure kulture) i Hrvatskoga radija, također i u dječjim emisijama, dok su lokalne televizijske i radijske postaje kontinuirano i s velikim zanimanjem pratile lokalne programe Manifestacije.

$\mathrm{Na}$ samome početku, Organizacijski odbor Manifestacije u prvim je pozivima na suradnju istaknuo važnost romana ovim riječima: „Šegrt Hlapić već je sto godina dio djetinjstva gotovo svakoga djeteta u Hrvatskoj. Roman Ivane Brlić-Mažuranić jedna je od onih nevidljivih spona koje nas povezuju zajedničkim čitateljskim iskustvom od najranije dječje dobi. Šegrt Hlapić je općeprihvaćeni junak djetinjstva hrvatske nacije, a Čudnovate zgode šegrta Hlapića najobjavljivanija hrvatska dječja knjiga (i, vrlo vjerojatno, ne samo dječja).“ Potrebu obilježavanja stote obljetnice Šegrta Hlapića u potpunosti opravdavaju činjenice da ne postoji drugo djelo hrvatske dječje književnosti koje bi tako dugo i tako značajno bilo prisutno u hrvatskoj kulturi, koje bi bilo tako sveprisutno u cijeloj Hrvatskoj, koje je toliko prelazilo granice Hrvatske, u europskim, ali i u svjetskim okvirima te koje se toliko prelilo preko književnoga okvira svoga postojanja kao što se to dogodilo sa Šegrtom Hlapićem, ne samo u medijskom pogledu (kazališne adaptacije, film, radio-adaptacije), i ne samo u komercijalnom smislu (iskorištavanje Hlapićeva lika od imena trgovina do likova u udžbenicima), već i u svakodnevnom govoru i frazeologiji. Stoga su na samome početku bili postavljeni sljedeći ciljevi: upozoriti na ovaj nedovoljno prepoznati temelj hrvatske kulture, potaknuti daljnja znanstvena istraživanja toga djela i njegova konteksta te pobuditi interes za takva istraživanja u međunarodnoj javnosti, kao i afirmirati vrijednosti koje se Hlapićem nude hrvatskoj dječjoj čitateljskoj publici. Prema prvome prijedlogu za organizaciju Manifestacije, koji je Berislav Majhut, kao predsjednik HIDK, uputio potencijalnim suradnicima tijekom 2012. godine, sve je to bilo potrebno jer je bilo jasno da Šegrt Hlapić u hrvatskoj kulturi nije do tada bio prepoznat ni vrednovan na primjeren način, „bilo zbog svoje skromnosti, skromnoga prebivališta (u dječjoj književnosti), skromnih okolnosti (u sjeni velikih Priča iz davnine) ili skromnih prijatelja (djece koja na njega nezahvalno zaborave kad odrastu)“. Osim toga, valjalo je podsjetiti da je Šegrt Hlapić i sastavni dio baštine europske i svjetske dječje književnosti, sasvim ravnopravan drugim međunarodnim dječjim klasicima, i to ne samo stoga što je kroz prijevode već više od osam desetljeća prisutan u europskim i izvaneuropskim književnostima.

Manifestacija Hlapić 2013. uspjela je ostvariti zacrtane ciljeve i opravdati razloge svojega pokretanja. Danas se o Hlapiću zna neusporedivo više nego što se znalo prije godinu dana. O ovome romanu je u obljetničkoj godini napisano na desetke znanstvenih studija dok je nekoliko diplomskih radova spremno za obranu pred stručnim povjerenstvima. Hlapić je postao vidljiviji i na međunarodnoj sceni. Možemo se samo nadati da će Hrvatska udruga istraživača dječje književnosti nastaviti s ovakvim aktivnostima na ovako uspješan način te $\mathrm{i}$ dalje promovirati neopravdano zapostavljene vrijednosti hrvatske kulture, prikrivene u dječjoj književnosti.

Ivana Faletar Horvatić 


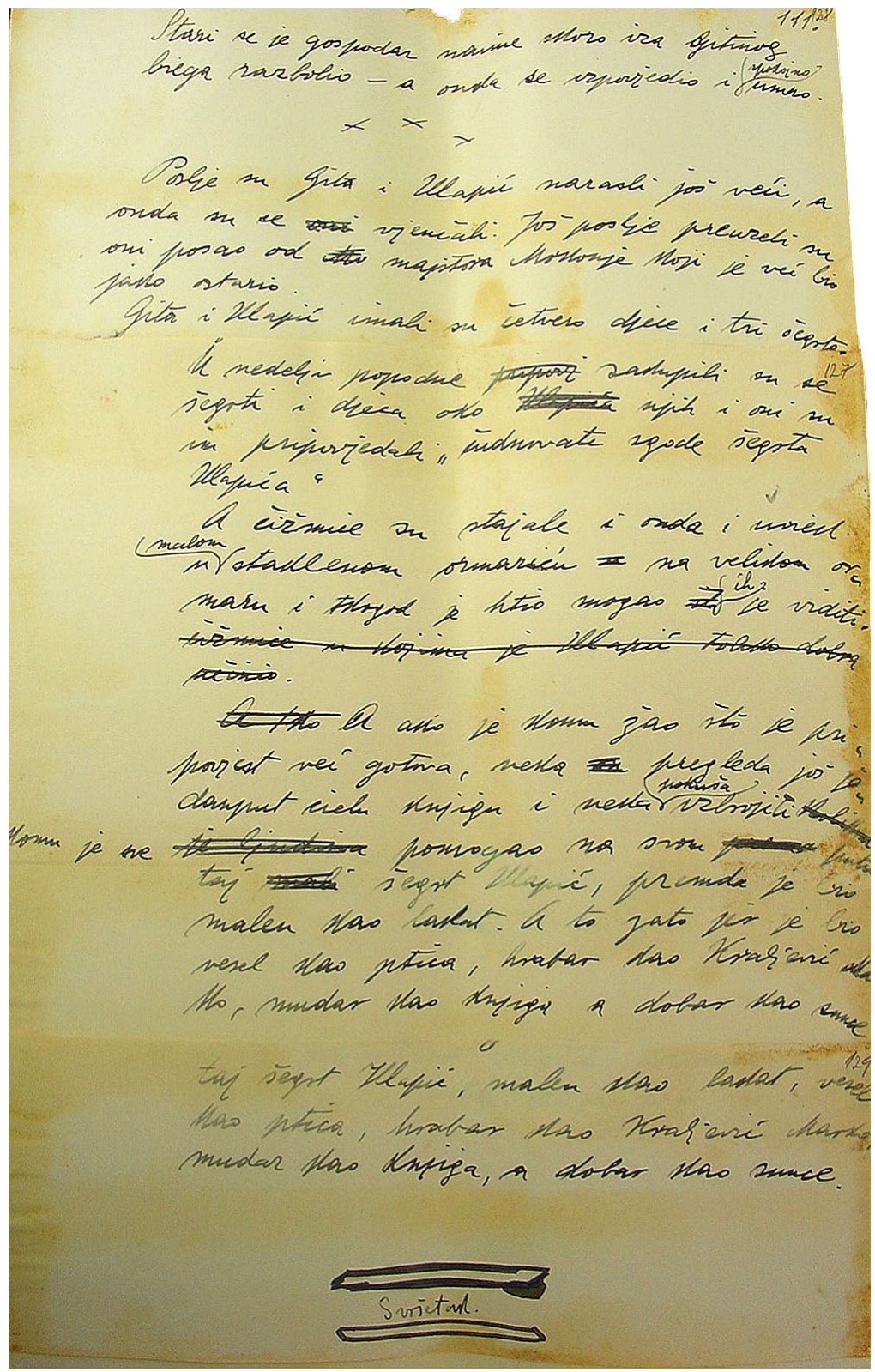

Arhiv obitelji Brlić, kutija inv. br. 82, svežnjić 8 .

Rukopis romana Čudnovate zgode šegrta Hlapića Ivane Brlić-Mažuranić. Završetak romana.

Original manuscript of The Strange Adventures of Hlapich the Apprentice by Ivana Brlić-Mažuranić. The ending of the novel. 


\title{
Bilješke o autorima • Notes on Contributors
}

\begin{abstract}
Professor Hans-Heino Ewers, DPhil, Director of the Institute for Children's Literature Research, teaches German Literature and Children's Literature at the Johann Wolfgang Goethe-University at Frankfurt/Main. He is the initiator and co-editor of the yearbook Children's Literature Research, published since 1995. He publishes studies on the theory and history of children's literature as well as on contemporary children's literature. His books include Literatur für Kinder- und Jugendliche (2012), an introduction to children's literature research, and Erfahrung schrieb's und reicht's der Jugend (2010) and Literaturanspruch und Unterhaltungsabsicht (2013), collected studies on historical and present-day German children's literature.<ewers@em.uni-frankfurt.de>
\end{abstract}

Ivana Faletar Horvatić (1984.) zaposlena je kao dipl. knjižničar-informator u Gradskoj knjižnici (KGZ) u Zagrebu. Aktivno se bavi promicanjem čitanja i pismenosti kao tajnica Hrvatskog čitateljskog društva i predstavnica Hrvatske pri Europskom udruženju čitateljskih udruga (FELA) te članica nekoliko domaćih i međunarodnih stručnih udruga. Ranije objavljeni znanstveni radovi i prijevodi mahom su iz područja informacijskih znanosti, kao i projekti u kojima volonterski sudjeluje. <ivana.faletar@kgz.hr>

Željka Flegar, PhD (1978) Assistant Professor at the University of Osijek, teaches courses in children's literature, media and drama in English. Her research deals with spontaneous verbal expression characteristic of improvisational theatre, deviation from the norm, subversiveness and the intricacies of the English language and literary discourse, such as word play, nonsense, the creation of neologisms, as well as the technique of metafiction. Her research has been published in Croatia and abroad, and she has hosted theatre workshops and staged plays with people of all ages. <zflegar@ufos.hr>

Dr. sc. Katarina Ivon (1976.) docentica je na Odjelu za izobrazbu učitelja i odgojitelja Sveučilišta u Zadru gdje je nositeljica i izvoditeljica kolegija Temeljni pojmovi teorije književnosti i Hrvatska književnost $u$ dijaspori te suradnica na kolegijima iz dječje književnosti i novije hrvatske književnosti. Njezini primarni znanstveni interesi usmjereni su književnoj i kulturnoj teoriji, posebice književnoj imagologiji. <kivon@unizd.hr>

Corinna Jerkin magistra je edukacije hrvatskoga jezika i književnosti i filozofije. Pohađa Poslijediplomski sveučilišni doktorski studij kroatistike na Filozofskome fakultetu u Zagrebu. Autorica je dvaju znanstvenih radova, poglavlja u e-knjizi i nekoliko prikaza književnih djela. Područja su njezinih znanstvenih interesa: književnost za djecu i mladež, teorija i filozofija književnosti, stilistika, recepcija i čitanje književnih djela te ženski žanrovi.<corinna.jerkin@yahoo.com>

Martina Jurić (1988) holds an MA in English Language and Literature (specializing in translation) and Comparative Literature obtained at the Faculty of Humanities and Social Sciences in Zagreb. Her academic interests include translation studies, cultural geography and film studies. She is currently employed as a translator at the European Parliament in Luxembourg.<martina.juric@hotmail.com>

Martina Jurišić (1988.) magistra je kroatologije i magistra edukacije kroatologije te doktorandica na Poslijediplomskom doktorskom sveučilišnom studiju kroatologije na Hrvatskim studijima. Zaposlena je kao stručna suradnica u izdavačkoj kući V. B. Z. Njezini su znanstveni interesi antimodernističke tendencije u dječjoj književnosti i rodna problematika. Do sada je objavila nekoliko radova u časopisima Zarez, Književnost $i$ dijete te jedan rad u časopisu Zagreb, moj grad.<martinajurisic4@gmail.com> 
Nada Kujundžić (1983) is a doctoral student at the Faculty of Humanities and Social Sciences at the University of Zagreb and the Faculty of Humanities at the University of Turku. She has published articles, essays and book reviews in several Croatian journals (Hrvatski filmski ljetopis, Književna smotra, Narodna umjetnost, Treća, Zarez). Her research interests include oral narratives, fairy-tale studies (in particular the Brothers Grimm, literary and cinematic adaptations/re-tellings of fairy tales), children's literature, film, popular genres and women's writing.<nadkuj@utu.fi>

Mateja Latin (1990) is a student at the Faculty of Teacher Education in Zagreb. She is currently in the fifth and final year of her studies. This issue of Libri \& Liberi includes her first published work.<latinmateja@gmail.com>

Dr. sc. Sanja Lovrić Kralj (1983.) poslijedoktorandica je na Učiteljskome fakultetu Sveučilišta u Zagrebu, Odsjek u Petrinji gdje drži nastavu iz kolegija dječje književnosti i medijske kulture. Obranila je doktorski rad pod nazivom Paradigme tridesetih godina 20. st. u hrvatskoj dječjoj književnosti. Objavljuje radove iz područja povijesti hrvatske dječje književnosti. Tajnica je Hrvatske udruge istraživača dječje književnosti. <sanja.lovric@ ufzg.hr>

Mag. prevođenja Martin Machata viši je lektor na Odsjeku za zapadnoslavenske jezike i književnosti Filozofskog fakulteta u Zagrebu, na kojem drži nekoliko kolegija jezične nastave, uglavnom slovačke jezične vježbe i prijevodno stilističke i kulturološke kolegije. U zadnjih desetak godina objavio je u domaćim i inozemnim zbornicima te recentnoj periodici niz članaka kulturološko-jezične i translatološke komparativne tematike. U književnim časopisima Quorum (20/2) i Književna revija (46/2) objavljeni su mu prijevodi pripovijedaka istaknutih slovačkih pisaca (Balla, Šikula, Mňačko, Puškáš, Závadová).<mmachata@ffzg.hr>

Dr. sc. Berislav Majhut (1956.) izvanredni je profesor na Učiteljskome fakultetu Sveučilišta u Zagrebu, Odsjek u Petrinji. Predaje kolegije iz dječje književnosti i medijske kulture. Njegovi su znanstveni interesi uglavnom vezani uz povijest hrvatske dječje književnosti, naratologiju i ilustraciju. Predsjednik je Hrvatske udruge istraživača dječje književnosti. $<$ berislav.majhut@ufzg.hr>

Dr. sc. Suzana Marjanić (1969.) znanstvena je savjetnica na Institutu za etnologiju i folkloristiku u Zagrebu. Njezino je znanstveno zanimanje usmjereno na mitske teme u usmenoj književnosti, kulturnu animalistiku te antropologiju izvedbe. Autorica je knjiga Glasovi „Davnih dana“: transgresije svjetova u Krležinim zapisima 1914-1921/22. i Kronotop hrvatskoga performansa: od Travelera do danas. <suzana@ief.hr>

Vedran Markulin (1984.) slikarski je dizajner, odgojitelj predškolske djece i magistar primarnoga obrazovanja. Područja su njegova interesa likovna umjetnost (slikarstvo, ilustracija, grafički dizajn) te stvaralaštvo u odgoju i obrazovanju. Izlagao je likovne radove na dvjema samostalnim i na više skupnih izložaba među kojima su i međunarodne, te je sudjelovao u likovnom opremanju knjiga, bio urednik kataloga i sudjelovao u postavu brojnih izložbi.<vedran.markulin@gmail.com>

Dr. sc. Petra Mrduljaš Doležal doktorirala je teoriju i povijest književnosti 2010. godine uz mentorsko vodstvo Zorana Kravara na Filozofskom fakultetu u Zagrebu gdje kao vanjska suradnica drži kolegije iz svjetske književnosti na Odsjeku za kroatistiku. Autorica je knjige Prstenovi koji se šire: Struktura i ideologija prapriče u djelima J.R.R. Tolkiena (Algoritam, 2012.), za koju je nagrađena godišnjom nagradom SFERA za teoriju i nominirana za nagradu Kiklop. S engleskoga jezika prevela je više od trideset naslova za veće hrvatske izdavače. Predsjednica je Društva hrvatskih književnih prevodilaca. <petramrduljas@yahoo.com> 
Maja Njire (1990) has recently obtained her Master's degree in Primary Education and is currently working as a teacher at the "Ivan Gundulić" Primary School in Dubrovnik. Her final thesis dealt with Harry Potter in Croatian translation. Her main interests include the use of literary works and their screen adaptations in the classroom. This issue of Libri \& Liberi contains her first published book review. <maja_njire@hotmail.com>

Dina Alexandra Pavković (1991) is a final year student at the Faculty of Teacher Education in Zagreb. Her interests include children's literature and picturebooks and their uses with young learners. This issue of Libri \& Liberi contains her first published book review. $<$ alexandra.pavkovic@gmail.com>

Dr. sc. Vladimira Rezo (1973.) viša je asistentica na Institutu za hrvatski jezik i jezikoslovlje u Zagrebu. Područja njezina zanimanja su povijest hrvatskoga jezika, tekstologija, leksikografija, leksikologija, povijest i teorija književnosti, književna periodika i dječja književnost, napose stvaralaštvo Ivane Brlić-Mažuranić. Suradnica je na projektu Kritičko izdanje sabranih djela Ivane Brlić-Mažuranić te na projektu objavljivanja autoričine rukopisne ostavštine. Radove objavljuje u hrvatskim i međunarodnim časopisima i zbornicima.<vrezo@ihjj.hr>

Spomenka Štimec (1949.) bavi se esperantom od 1965. godine. Tajnica je Hrvatskoga saveza za esperanto i članica Međunarodne esperantske književne akademije. Bila je članica Predsjedništva Svjetskoga saveza esperantista (1989. - 1992.). Predavala je esperanto diljem svijeta. Na esperantu je objavila niz knjiga koje su prevedene i na japanski, njemački, francuski i kineski jezik. <esperanto@zg.t-com.hr>

Dr. sc. Jelena Vignjević viša je predavačica na Učiteljskome fakultetu Sveučilišta u Zagrebu. Održava nastavu iz jezikoslovnih kroatističkih kolegija. Njezino je znanstveno zanimanje usmjereno na područje jezikoslovne kroatistike, ovladavanja jezikom, jezične stilistike hrvatske dječje književnosti te glagoljične i latinične pismenosti na hrvatskome jeziku.<jelena.vignjevic@ufzg.hr>

Dr. sc. Dubravka Zima docentica je na Odjelu za kroatologiju na Hrvatskim studijima Sveučilišta u Zagrebu gdje predaje kolegije iz dječje književnosti, novije hrvatske i svjetske književnosti. Objavila je knjige Ivana Brlić Mažuranić (Zagreb, ZZOK, 2001.) i Kraći ljudi. Povijest dječjeg lika u hrvatskom dječjem romanu (Zagreb, Školska knjiga, 2011.). <dzima@hrstud.hr>

Red. prof. art. Danijel Žabčić (1950.) radi na Učiteljskom fakultetu Sveučilišta u Zagrebu. Do sada je objavio sedam knjiga s autorskim tekstovima (likovne monografije, teorijski spisi) te tekstove u časopisima za kulturu i umjetnost. Izlaže svoje slikarske radove u zemlji i inozemstvu te je do sada imao dvadeset i osam samostalnih izložbi. Za slikarski rad dodijeljeno mu je šest eminentnih nagrada.<danijel.zabcic@ufzg.hr> 


\section{Recenzenti u ovom godištu • Reviewers in this Volume}

Zahvaljujemo kolegicama i kolegama na recenziranju radova ponuđenih za tisak u drugome godištu časopisa Libri \& Liberi.

We wish to thank these colleagues for their contribution to the journal by reviewing the manuscripts submitted for the second volume of Libri \& Liberi.

Dr. sc. Katarina Aladrović Slovaček, Učiteljski fakultet Sveučilišta u Zagrebu (Zagreb, Hrvatska)

Dr. sc. Robert Bacalja, Odjel za izobrazbu učitelja i odgojitelja, Sveučilište u Zadru (Zadar, Hrvatska)

Izv. prof. art. Antonija Balić-Šimrak, Učiteljski fakultet, Sveučilište u Zagrebu (Zagreb, Hrvatska)

Dr. Marina Balina, Isaac Funk Professor of Russian Studies, Illinois Wesleyan University (Bloomington, IL, USA)

Dr. Susanna Barsotti, Facoltà di Studi Umanistici (Cagliari, Italy)

Dr. Tamás Bényei, University of Debrecen (Debrecen, Hungary)

Mag. Dr. Susanne Blumesberger, Institut für Germanistik (Wien, Österreich)

Dr. sc. Jadranka Brnčić, Filozofski fakultet Sveučilišta u Zagrebu (Zagreb, Hrvatska)

Dr. Beverly Lyon Clark, Wheaton College (Norton, MA, USA)

Prof. Dr. Gerhard Härle, Pädagogische Hochschule Heidelberg (Heidelberg, Deutschland)

Prof. dr. sc. Stjepan Hranjec, Učiteljski fakultet Sveučilišta u Zagrebu, Odsjek Čakovec (Čakovec, Hrvatska)

Prof. dr. sc. Ibrahim Kajan, Fakultet humanističkih nauka Univerziteta „Džemal Bijedić" (Mostar, Bosna i Hercegovina)

PhDr. Alica Kulihová, PhD., Filozofická fakulta Univerzity Komenského v Bratislave (Bratislava, Slovenská republika)

Dr. sc. Svjetlan Lacko Vidulić, Filozofski fakultet, Sveučilište u Zagrebu (Zagreb, Hrvatska)

Dr. Lesa Lockford, Bowling Green State University (Bowling Green, OH, USA)

Dr. sc. Bojan Marotti, Hrvatska akademija znanosti i umjetnosti (Zagreb, Hrvatska)

Dr. sc. Petra Mrduljaš Doležal, vanjska suradnica na Filozofskom fakultetu Sveučilišta u Zagrebu (Zagreb, Hrvatska)

PhDr. Jaroslav Otčenášek, $\mathrm{PhD}$., Etnologický ústav $A V \check{C} R$ (Praha, Česká republika)

Dr. sc. Tatjana Peruško, Filozofski fakultet, Sveučilište u Zagrebu (Zagreb, Hrvatska)

Prof. dr. sc. Velimir Piškorec, Filozofski fakultet, Sveučilište u Zagrebu (Zagreb, Hrvatska) 
Dr. sc. Tatjana Pišković, Filozofski fakultet, Sveučilište u Zagrebu (Zagreb, Hrvatska) Prof. dr. sc. Edin Pobrić, Filozofski fakultet u Sarajevu (Sarajevo, Bosna i Hercecgovina) Doc. dr. sc. Marina Protrka Štimec, Filozofski fakultet, Sveučilište u Zagrebu (Zagreb, Hrvatska)

Doc. PhDr. Eva Tibenská, CSc., Filozofická fakulta Univerzity sv. Cyrila a Metoda v Trnave (Trnava, Slovenská republika)

Doc. dr. sc. Sanja Vrcić-Mataija, Odjel za nastavničke studije u Gospiću, Sveučilište u Zadru (Gospić, Hrvatska)

Dr. Vladimir Zorić, School of Cultures, Languages and Area Studies, University of Nottingham (Nottingham, UK) 